UNIVERSIDADE DE SÃO PAULO

FACULDADE DE FILOSOFIA, LETRAS E CIÊNCIAS HUMANAS

DEPARTAMENTO DE HISTÓRIA

PROGRAMA DE PÓS GRADUAÇÃO EM HISTÓRIA ECONÔMICA

CRÉDITO E IMPERIALISMO NA ECONOMIA BRASILEIRA: O CASO DAS COMPANHIAS DE SEGUROS (1889-1914)

Versão Corrigida

Beatriz Duarte Lanna

São Paulo

2018 


\author{
UNIVERSIDADE DE SÃO PAULO \\ FACULDADE DE FILOSOFIA, LETRAS E CIÊNCIAS HUMANAS \\ DEPARTAMENTO DE HISTÓRIA \\ PROGRAMA DE PÓS GRADUAÇÃO EM HISTÓRIA ECONÔMICA
}

\title{
CRÉDITO E IMPERIALISMO NA ECONOMIA BRASILEIRA: O CASO DAS COMPANHIAS DE SEGUROS (1889-1914)
}

\author{
Versão Corrigida
}

Beatriz Duarte Lanna

\begin{abstract}
Dissertação apresentada ao Programa de PósGraduação em História Econômica do Departamento de História da Faculdade de Filosofia, Letras e Ciências Humanas da Universidade de São Paulo
\end{abstract}

Orientador: Prof. Dr. Alexandre Macchione Saes

De acordo: Prof. Dr. Alexandre Macchione Saes

São Paulo 
Dissertação de Mestrado

Aluna: Beatriz Duarte Lanna

Título: Crédito e Imperialismo na economia brasileira: o caso das companhias de seguros (1889-1914)

Defendida em: 16 de novembro de 2017

Banca Examinadora

Prof. Dr. Alexandre Macchione Saes

Orientador - Programa de Pós-Graduação em História Econômica/USP

Profa. Dra. Cláudia Alessandra Tessari (EPPEN/UNIFESP)

Prof. Dr. Thiago Fontelas Rosado Gambi

Instituto de Ciência Sociais Aplicadas/UNIFAL

Prof. Dr. Guilherme Grandi

FEA/USP 
Para minha mãe (em memória) 


\title{
Resumo
}

Essa dissertação trata da atuação das companhias de seguros no Brasil entre os anos de 1889 e 1914. Busca-se apresentar a ampla inserção dessas companhias na economia brasileira de então; contata-se que para além da concessão de seguros, essas firmas tiveram ativa participação financeira, concedendo crédito e financiando o Estado brasileiro por meio da contínua compra de apólices da dívida pública federal. Buscou-se enfatizar a transição de uma dinâmica mercantil para outra financeira, comprovada para as companhias de seguros sobretudo a partir da década de 1890, e mostrar como a atividade seguradora no Brasil de então foi influenciada pelas novas condições do capitalismo global.

\begin{abstract}
This dissertation deals with the performance of insurance companies in Brazil between 1889 and 1914. It seeks to present the wide insertion of these companies in the brazilian economy; it is concluded that in addition to the insurance concession, these firms had an active financial participation, granting credit and financing the Brazilian State through the continuous purchase of federal public debt policies. We sought to emphasize the transition from a commercial to a financial dynamic, proven by insurance companies especially since the 1890s, and also show how the insurance activity of that time was influenced by the new conditions of global capitalism,
\end{abstract}




\section{Agradecimentos}

Agradeço à FAPESP, processo nº 2015/04491-4, pela concessão da bolsa sem a qual eu não poderia ter realizado esta pesquisa.

Um agradecimento especial ao meu orientador, o professor Alexandre Saes, pela maneira atenciosa com que conduziu esses anos de trabalho. Obrigada pela presença constante, e sobretudo pela seriedade e tranquilidade.

À banca de defesa, composta pelos professores Guilherme Grandi, Thiago Gambi e Cláudia Tessari pela enorme contribuição com críticas e sugestões à essa pesquisa desde o exame de qualificação.

Aos companheiros do Seminário Brancaleone, na FEA-USP, pelas discussões e debates desde minha entrada no grupo, no início de 2015.

Ao professor João Paulo Pimenta, um agradecimento carinhoso pelos anos de formação durante e após a graduação.

Aos professores Rafael Marquese e Alexandre de Freitas Barbosa pela disponibilidade e atenção com que discutiram e fizeram críticas ao texto da dissertação.

Aos queridos companheiros do LabMundi, da História-USP, pelos anos de discussão, debates e encontros.

Ao meu pai, Marcos, e às minhas irmãs, Ligia e Teresa, pela amizade.

Aos meus avós, Helena, Amadeu, Maria Lucia e Quino, pelo carinho.

Às minhas queridas amigas Ana, Gabriela, Helena, Manuela, Maria Eugênia, Isabela,

Luisa e Fabíola, parceiras de vida.

E finalmente ao Pablo, por ser meu companheiro. 


\section{SUMÁRIO}

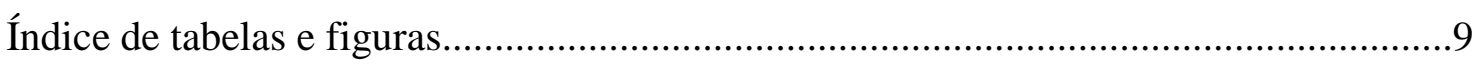

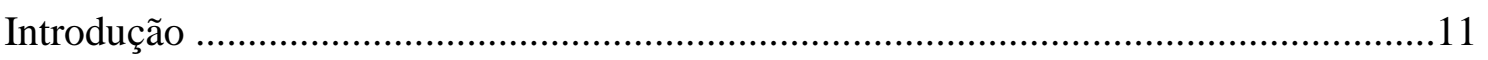

Capítulo 1. As companhias de seguro no Brasil nos marcos da primeira globalização ....................................................................................................................20

1.1. A Legislação de seguros antes da Proclamação da República ..............................20

1.2. Expansão do capital estrangeiro e o crescimento do investimento externo no Brasil,

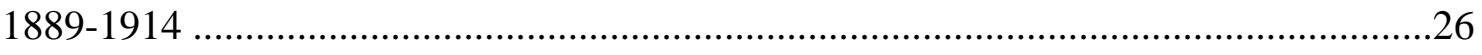

1.3. Ampliação dos circuitos financeiros no Brasil e instabilidade cambial...................43

1.4. As companhias de seguros e as associações mútuas e de montepio ........................52

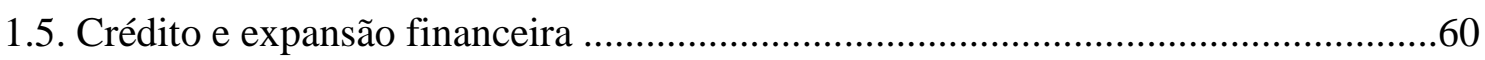

Capítulo 2. A política econômica na República ......................................................67

2.1. A Legislação de seguros durante a República ....................................................67

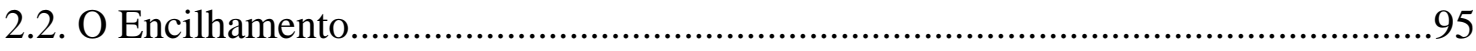

2.3. As companhias de seguros e as possibilidades de crédito urbano, imobiliário e

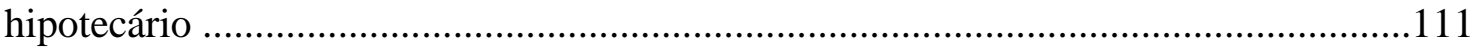

2.4. Companhias de seguros e casas exportadoras ....................................................118

2.5. As consequências do Encilhamento e o papel das companhias de seguros na formação do capital industrial brasileiro

2.6. As companhias de seguros e o Convênio de Taubaté

2.7. A economia brasileira às vésperas da Primeira Guerra Mundial

Capítulo 3. A dinâmica mercantil e financeira das companhias de seguros no Brasil: exemplos empíricos ......................................................................................................161

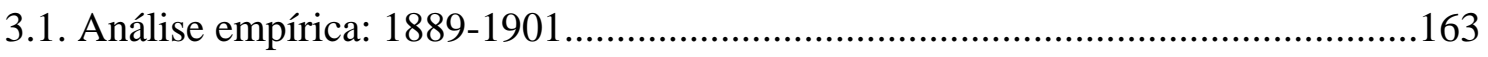

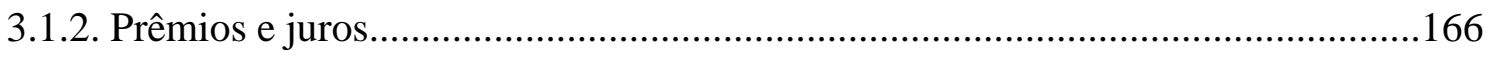

3.1.3. As companhias de seguros no Sul do Brasil e no circuito comercial do Rio da

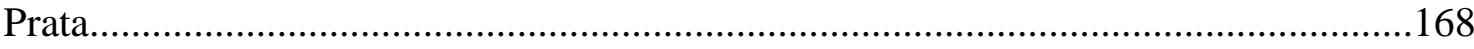

3.1.4. As companhias de seguros e as de navegação...................................................170 
3.1.5. As propriedades móveis e imóveis e as companhias de estrada de ferro 173

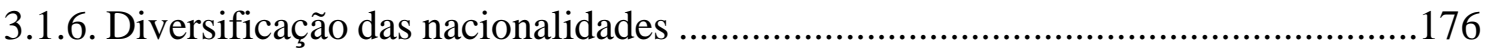

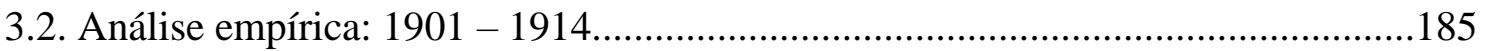

3.2.1. A promulgação do Regulamento Murtinho e seu impacto sobre as firmas nacionais.

185

3.3. Mapeamento e cruzamento do capital: os proprietários das companhias de seguros e

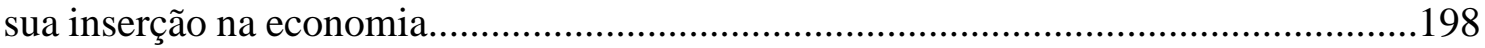

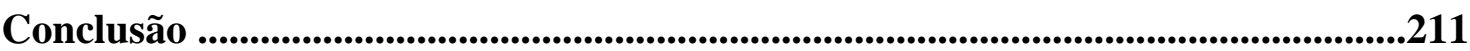

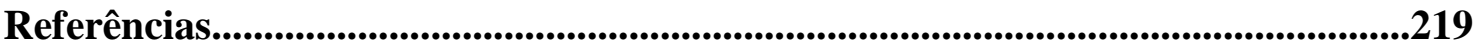




\section{ÍNDICE DE TABELAS E FIGURAS}

Tabela 1 - Estimativa para o Balanço de Pagamentos do Brasil, 1876-1897

Tabela $2-$ Saldo da balança comercial brasileira. 1901-1908

Tabela 3 - Remessas para fora do país

Tabela 4 - Companhias de seguros em funcionamento no Brasil, 1905. .72

Tabela 5 - Depósitos, prêmios e sinistros de companhias de seguros marítimos e terrestres, nacionais estrangeiras,

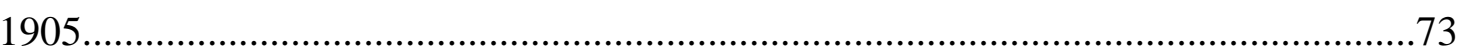

Tabela 6 - Reservas, seguros efetuados, pagos e em vigor para companhias de seguros de vida, nacionais e estrangeiras,

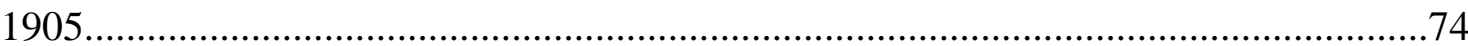

Tabela 7 - Capital emitido, capital realizado e depósito no Tesouro das companhias de seguros, 1906 .75

Tabela 8 - Capital emitido e prêmios recebidos: companhias de seguros marítimos $\begin{array}{lll}\text { estrangeiras } & \text { e } & \text { nacionais, }\end{array}$ .87

Tabela 9 - Capital emitido e prêmios recebidos: companhias de seguros de vida estrangeiras e nacionais, 1910

Tabela 10 - Companhias cotadas na Bolsa do Rio de Janeiro, 1891 .98 
Tabela $11-$ Dados financeiros das companhias e seguros, 1916

Tabela 12 - Reservas, ativos, garantias, prêmios e número de novos seguros em vigor no contexto pós Convênio de Taubaté,

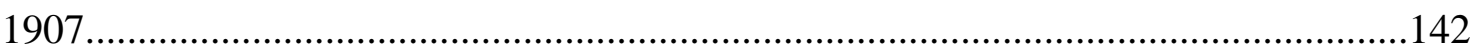

Figura 1 - Anúncio da Companhia de Seguros Equitativa no jornal Correio Paulistano, 1906 140

Figura 2 - Anúncio da Companhia de Seguros Sul América no jornal Correio Paulistano, 1906 .141 


\section{Introdução}

É sabido que a economia brasileira passou por mudanças profundas na segunda metade do século XIX e início do XX. A primeira década republicana pode ser considerada um momento emblemático no que diz respeito às transformações sofridas pelo capitalismo no Brasil; a abolição da escravidão, o início da remuneração da força de trabalho e as mudanças de regime político estão dentre as modificações mais significativas. Na tentativa de contribuir para a compreensão da formação do capitalismo brasileiro, esta pesquisa tem como foco de análise a constituição do mercado financeiro nacional, tendo como objeto primordial de estudo as companhias de seguros, nacionais e estrangeiras, que se instalaram em São Paulo e no Rio de Janeiro entre 1889 e 1914. Inicialmente tidas como um apêndice do setor bancário, aos poucos as companhias de seguros passaram a ganhar independência e forma própria.

A partir da pesquisa com fontes primárias, notamos que o funcionamento dessas companhias de seguro passou pela transição de um padrão dominantemente mercantil a uma forte dinâmica financeira. Além disso, contatamos que, a despeito de bastante expressivo, o número de firmas seguradoras estrangeiras era menor que o de firmas nacionais. A formação de um setor propriamente brasileiro para o ramo parece ter começado desde meados do século XIX e se consolidado já na primeira década do século $\mathrm{XX}$.

Cabe aqui realizarmos uma breve reconstituição da situação dessas empresas antes do ano de 1889. As primeiras seguradoras formadas no Brasil datam do período de chegada da corte portuguesa ao Rio de Janeiro. A abertura das companhias cumpria com o papel de fornecer maior segurança econômica e estimular a expansão do comércio marítimo local. Ao longo do século XIX, acompanhando o processo de formação do Estado brasileiro e o crescimento da economia imperial, assistiu-se à expansão do número de empresas de seguros nacionais e ao início da entrada das primeiras firmas estrangeiras, que chegam sobretudo a partir da década de 1860. As companhias de seguros que se instalaram no Brasil estabeleceram suas atividades junto às empresas de comércio marítimo, de importação e companhias de navegação. Na origem, as sociedades aqui estabelecidas ou construídas respondiam ao caráter mercantil da economia brasileira: buscavam assegurar garantias ao transporte marítimo, reproduzindo as regulamentações 
e as experiências das pioneiras empresas europeias. ${ }^{1}$ Com a diversificação do perfil de apólices atendidas - que ao longo do tempo deixam de se relacionar apenas às transações marítimas e voltam-se também ao comércio terrestre, ao seguro de vida, contra incêndio e até mesmo de escravos -, e com a ampliação de suas áreas de atuação por meio de agências, as companhias alcançaram um crescente número de Províncias; tem-se que a prioridade do negócio, até fins do século XIX, era de fomentar o comércio nacional e dar mais garantias ao seu funcionamento.

As companhias de seguros, nesse sentido, são lembradas pela literatura como uma inovação institucional determinante para aumentar os ganhos de produtividade e para reduzir os custos de transação. ${ }^{2}$ Ao lado de outros arranjos instrucionais, como formação de economias de escala via a atuação de grandes empresas e o incentivo à inovação e à formação de patentes, a construção de companhias de seguros é tida pela bibliografia clássica como um exemplo de instituição capaz de reduzir as imperfeições do mercado. ${ }^{3}$ Entretanto, menor é o destaque dado ao papel financeiro desempenhado por essas sociedades que, ao movimentarem crescentes quantidades de capital dos fundos formados pelos segurados, envolviam-se em transações de crédito e financiamento da economia. ${ }^{4}$ Essa dinâmica torna-se mais presente no Brasil nos anos finais do século XIX, quando a estrutura financeira e econômica do país se complexifica.

A análise das transações do setor de seguros é realizada nesta pesquisa por meio do estudo de caso das empresas, cujas operações podem ser verificadas em fontes primárias tais como os relatórios anuais das sociedades para os acionistas, os Relatórios do Ministério da Fazenda, Atos do Poder Legislativo e Executivo, publicações no Diário Oficial, Retrospecto do Jornal do Commercio, Correio Paulistano, além de notícias de outros jornais. Destacamos o fato de não termos encontrado um corpus documental coeso cujo conteúdo fosse capaz de proporcionar uma visão diacrônica das companhias de

\footnotetext{
${ }^{1}$ É representativo o fato dos seguros terem sido tratados como um capítulo das legislações marítimas originárias do renascimento comercial, tais como o Consulat de la Mer, as Ordenanças de Barcelona (1435), de Philippe de Borgonha (1458), de Veneza (1468), entre outros. Cf. INSTITUTO DE RESSEGUROS DO BRASIL, Noções fundamentais de seguros. Rio de Janeiro: Imprensa Nacional, 1944; ALVIM, Pedro, Política brasileira de seguros. São Paulo: Ed. Manuais Técnicos de Seguros, 1980.

${ }^{2}$ NORTH, Douglass \& THOMAS, Robert Paul, "An economic theory of the growth of the Western World". Economic history review. Volume XXII, n. 1, 1970; SUPPLE, Barry, "Insurance in British History". WESTALL, Oliver. The historian and the business of insurance. Manchester: Manchester University Press, 1984; PEARSON, Robin, "Towards an historical model of services innovation: the case of the insurance industry, 1700-1914". Economic history review, n. 2, 1997.

${ }^{3}$ NORTH, Douglass \& THOMAS, Robert Paul, The rise of the Western World: a new Economic History. Cambridge: Cambridge University Press, 1973, p. 06.

${ }^{4}$ HILFERDING, R. O Capital Financeiro. São Paulo: Nova Cultural, 1985; LÊNIN, V. O imperialismo: fase superior do capitalismo. São Paulo: Global, 1987.
} 
seguros; a total ausência de arquivos privados impediu um olhar mais abrangente que pudesse revelar o desenrolar das firmas no longo prazo, e o único órgão regulador do setor, a Superintendência de Seguros Privados, não possui acervo referente ao século XIX ou início do XX. Isso significou a necessidade de arrolarmos como fonte primária essencial os jornais e periódicos da época, e coletamos os dados referentes aos anos entre 1889 e 1914 dia após dia em cada um dos periódicos analisados. Além disso, pudemos contar com as informações oficiais publicadas nos Atos do poder Executivo e Legislativo, bem como nos Relatório do Ministério da Fazenda.

O recorte temporal 1889-1914 foi escolhido por abarcar dois momentos bastante particulares da economia brasileira: se a primeira década republicana revela um ambiente de euforia econômica, gerado sobretudo pelo Encilhamento, também apresenta um cenário de instabilidade herdado da crise especulativa dos primeiros anos da República. Um segundo período, já no início do século XX, marca, por sua vez, uma fase de maior estabilidade econômica e de abundante entrada de capital estrangeiro no país, o que poderia sugerir mudanças tanto no perfil das atividades econômicas seguradas, como das possibilidades financeiras abertas.

Essa pesquisa parte do princípio de que por trás da participação financeira das seguradoras havia no Brasil de então uma fraca cadeia creditícia e poucas possibilidades de financiamento; a segunda metade do século XIX foi marcada por tentativas de consolidação de uma estrutura de crédito rural cujos resultados não foram capazes de salvar as propriedades agrícolas decadentes. Antes da vinda em grande quantidade dos bancos estrangeiros a partir da década de 1860 e da consolidação do Banco do Brasil em 1863, notamos a predominância de circuitos de crédito locais, sobretudo no estado de São Paulo, concedidos por fazendeiros dotados de poupanças ou comerciantes bemsucedidos. ${ }^{5}$ Nesses círculos de crédito regionais, os proprietários agrícolas devedores possuíam uma certa independência para com os credores das grandes capitais, e os circuitos de crédito não oficiais permaneceram importantes na economia brasileira até o início do século $\mathrm{XX}{ }^{6}{ }^{\mathrm{A}}$ demanda por crédito à indústria e às atividades urbanas era suprida sobretudo por fontes externas e tampouco resultou em desenvolvimento econômico local e sustentável.

\footnotetext{
${ }^{5}$ HANLEY, Anne, Native Capital: financial institutions and economic development in São Paulo, Brazil, 1850-1920. Stanford: Stanford University Press, 2005, p. 20

${ }^{6}$ MARCONDES, Renato Leite, A arte de acumular na economia cafeeira: Vale do Paraíba no século XIX. Lorena: editora Siciliano, 1998, p. 231,
} 
Citaremos como exemplo o caso da lei 2687 , de 06 de novembro de $1875^{7}$, que garantia empréstimos europeus aos bancos de crédito rural nacionais. Preocupados com a rentabilidade decrescente da lavoura escravocrata e incapazes de utilizar suas propriedades como garantia, os fazendeiros do final do Império, sobretudo os paulistas, demandaram do governo que garantisse $5 \%$ de juros aos investidores, brasileiros ou estrangeiros, que se propusessem a emprestar aos bancos regionais. ${ }^{8}$ Esta estrutura era parte constitutiva da dinâmica econômica brasileira, cujos investimentos contavam com abundante garantia por parte do Estado para resolução de projetos. As estradas de ferro, construídas como sociedades anônimas, podiam obter $7 \%$ de juros garantidos pelo Estado, tendo seu rendimento assegurado mesmo se fracassassem. ${ }^{9}$

A garantia de rendimentos ao capital estrangeiro por parte do governo estimulou a entrada de investimentos externos nas mais diferentes áreas. Por mais que não constatemos garantias estatais de lucro às companhias de seguros no Brasil de então, (característica marcante para o caso de bancos e ferrovias), consideraremos que as seguradoras estrangeiras se interessaram pelas possibilidades de um mercado periférico em formação e, de maneira mais geral, pelas oportunidades advindas da inserção em um ambiente de laços capitalistas incipientes. A despeito da persistência dos laços familiares na concessão de crédito no Brasil, constatamos que ao longo da segunda metade do século XIX o país aos poucos tornava-se mais institucionalizado e menos dependente de conexões pessoais. $\mathrm{O}$ fortalecimento dessa dimensão institucional, em contraposição à familiar, levava a uma relativa facilidade de acesso ao crédito, que ajudava a compor o que Anne Hanley denominou uma "democracia financeira". Essa circunstância assemelharia o Brasil aos EUA e o distanciava de outros lugares da América Latina, como o México, onde apenas aqueles dotados de ligações profundas com o governo obtinham financiamento. ${ }^{10}$

O período em questão, marcado por mudanças profundas nas condições da economia mundial, foi denominado por diferentes autores como "primeira globalização" ou "Era dos Impérios". ${ }^{11}$ De fato, constatamos à época intensa acumulação e liberação de

\footnotetext{
${ }^{7}$ FRANCO, Gustavo, Reforma monetária e instabilidade durante a transição republicana. Rio de Janeiro: BNDES, 1983, p. 90.

${ }^{8}$ SCHULZ, John, A crise financeira da abolição. São Paulo: Edusp, 2013, p. 115,

${ }^{9}$ SAES, Flavio, As ferrovias de São Paulo (1870-1940). São Paulo: Hucitec, 1981, p. 150

${ }^{10}$ HANLEY, Anne, Native Capital: financial institutions and economic development in São Paulo, Brazil, 1850-1920. Stanford: Stanford University Press, 2005, p. 18

${ }^{11}$ Os autores são, respectivamente, WILLIAMSON, Jeffrey, O'ROURKE, Kevin, "When did globalization begin?" in National Bureau of Economic Research. Cambridge, Massachussets: 2000, e HOBSBAWM, Eric. A era dos impérios. São Paulo: Paz e Terra, 1989
} 
capital dos países centrais, cuja presença e enraizamento na realidade brasileira modificava-a profundamente. $\mathrm{O}$ processo de exportação de capital do centro rumo à periferia que caracteriza o final do século XIX e início do XX está profundamente relacionado às possibilidades de ganhos financeiros encontradas pelo Brasil no período em questão. Conhecidos eventos que marcaram a vida econômica brasileira desta época dão mostras da ampla disponibilidade de recursos forâneos: o Funding Loan, em 1898, renegociação da dívida externa e empréstimo junto aos credores estrangeiros para pagamento de juros; a política restritiva de Joaquim Murtinho, Ministro da Fazenda de Campos Salles entre os anos de 1898 e 1902; o Convênio de Taubaté, de 1906, que delineou uma política de defesa do café baseada em empréstimos para compra e armazenagem do produto; a Caixa de Conversão, também de 1906, que permitiu que a taxa de câmbio se mantivesse estável até a Primeira Guerra.

Nesse sentido, em um período de expansão das atividades econômicas mundiais e dos laços entre o capitalismo central e periférico, fosse pelo comércio, investimento externo ou pelo capital, abriram-se inúmeras oportunidades para novos setores e atividades. $\mathrm{O}$ setor de seguros emergiu como uma nova opção de inversão, sendo um negócio rentável não somente pela ampla capacidade de inserção mercantil como também pelas possibilidades financeiras que seriam exploradas pelas companhias no período.

De maneira geral, tem-se que as principais políticas macroeconômicas da época se fizeram graças à boa inserção do café e da borracha no mercado externo e à presença de recursos na forma monetária que, liberados do centro do capitalismo, buscavam valorizar-se na periferia. $^{12}$

A formação da dívida brasileira, cujas origens remontam ao ano de 1828, era parte do referido processo de exportação de capital europeu, sobretudo da Inglaterra. No primeiro ano da República, em 1889, o Brasil contava com uma dívida passiva, interna e externa, de 760 mil contos de réis. ${ }^{13}$ Desde a década de 1820 , o número de títulos emitidos

\footnotetext{
12 O artigo de José Murilo de Carvalho "Aconteceu em um fim de século", publicado no jornal A Folha de São Paulo em 21 de fevereiro de 1999, traça um panorama da difícil situação econômica no Brasil de 1898, quando assume Campos Salles e seu Ministro da Fazenda, Joaquim Murtinho. À semelhança do governo de Fernando Henrique Cardoso no fim do século XX, entre 1898 e 1902 Campos Salles e Murtinho buscaram valorizar a moeda, contornar a crise cambial e conter a inflação galopante. http://www1.folha.uol.com.br/fsp/mais/fs21029903.htm. Acesso em 08/12/2016

${ }^{13}$ CARVALHO, José Murilo de, Teatro das sombras: a política imperial. Rio de Janeiro: Civilização Brasileira, 2007, p. 272. Segundo o autor, a maior parte da dívida contraída ao longo do Império tinha como objetivo cobrir os gastos da indenização paga pelo Estado brasileiro pós Independência, além das despesas com a repressão de rebeliões e revoltas regionais, e a Guerra do Paraguai. Uma porcentagem pequena da dívida havia sido contraída para gastos com investimento, sendo a maioria das despesas do Império de natureza não produtiva.
} 
pelo governo brasileiro e adquirido por banqueiros ingleses cresceu de forma expressiva. Pode-se constatar semelhante movimento em outros países da América Latina que, recém independentes das metrópoles ibéricas, encontravam-se em vias de formação das suas próprias dívidas nacionais. Seus títulos representavam opção de investimento mais vantajosa que a dívida britânica, marcada por retornos decrescentes desde meados do século XIX. ${ }^{14}$

Cabe aqui chamarmos atenção à existência de credores locais, igualmente interessados em financiar os Estados Nacionais em formação; no caso brasileiro, logo após o estabelecimento da dívida pelo parlamento no ano de 1828, traficantes de escravos e comerciantes do Rio de Janeiro se tornaram proeminentes compradores dos títulos públicos. ${ }^{15}$ Os bancos nacionais também passaram a comprar esses papéis, fazendo com que tais títulos da dívida compusessem cada vez mais os ativos bancários. Nas décadas de 1880 e 1890, temos que a consequência do aumento da compra dessas apólices pela praça carioca, além da formação de expressivo déficit fiscal, foi a diminuição acentuada do papel-moeda no Rio. A expressão financeira da economia fluminense em um momento anterior ao Encilhamento baseava-se nos títulos do governo; como consequência do elevado índice de compra de títulos, o papel moeda era retirado de circulação e o país convivia com baixa liquidez. ${ }^{16}$

A popularidade das apólices da dívida nacional cresceu de forma expressiva entre a elite brasileira ao longo do século XIX, sobretudo a partir da década de 1860. Ao longo deste trabalho, apresentaremos sucessivos exemplos do envolvimento das companhias de seguros na compra desses títulos. ${ }^{17}$ Estes tornavam-se cada vez mais atraentes; após um período de preços elevados do café, cujo auge deu-se entre 1886 e 1896, constatamos relativa decadência agrícola do principal produto de exportação brasileiro. Com a referida queda na rentabilidade cafeeira, a elite econômica viu-se impelida a diversificar suas inversões, pois a cafeicultura não mais oferecia perspectiva de crescimento. ${ }^{18}$ Buscou-se,

\footnotetext{
${ }^{14}$ SUMMERHILL, William, Inglorious Revolution: Political Institutions, Sovereign Debt, and Financial Underdevelopment in Imperial Brazil. Yale University Press, 2015, p. 49.

15 Ibidem, p. 03.

16 TANNURI, Luiz Antonio, O Encilhamento, São Paulo: Hucitec, 1981, p. 29. Segundo Luiz Antonio Tannuri, a guerra do Paraguai (1864 e 1870) foi financiada sobretudo internamente, através de emissões oficiais de papel-moeda e de apólices da dívida pública interna. Esse mecanismo permaneceu mesmo após o término da Guerra, tornando-se parte do padrão de financiamento brasileiro.

${ }^{17}$ Como veremos em breve neste texto, a partir de 1895 as companhias de seguros tinham obrigação de investir determinada quantia no Tesouro Nacional para poderem funcionar; o interesse dessas firmas pelo investimento em dívidas públicas, no entanto, fez-se para além dessa obrigação.

18 TANNURI, Luiz Antonio, obra citada, p. 28.
} 
portanto, investir na ampla disponibilidade de títulos da dívida nacional, cuja aceitação foi bastante ampla no Rio de Janeiro. ${ }^{19}$

A necessidade de financiamento por parte do governo criou uma nova forma de investimento, a princípio segura e garantida, que atraiu não apenas o capital estrangeiro como também a elite econômica paulista e fluminense, e as apólices da dívida passaram a compor cada vez mais os ativos bancários. ${ }^{20}$ Sabemos que os títulos públicos, além de considerados uma opção segura e de rendimento atrativo, podiam ser negociados com pequeno deságio e possuíam uma relativa liquidez, sobretudo se comparados a outros títulos como letras hipotecárias ou de construção predial. O presente trabalho apresentará recorrentes exemplos de inserção das companhias de seguros, nacionais ou estrangeiras, no mercado da dívida pública brasileira, tornando-se importantes detentoras dos referidos títulos públicos entre os anos de 1889 e 1914.

A segurança por detrás dos investimentos na dívida nacional tinha uma razão de ser. Desde a década de 1820 e ao longo de todo o Império, o Brasil serviu fielmente seus credores e obteve significativo reconhecimento entre os banqueiros estrangeiros que financiaram o governo. A despeito dessa credibilidade no âmbito do comércio de títulos públicos, o país não foi bem-sucedido na formação de um pujante mercado de crédito privado, cujo bom funcionamento teria possibilitado, no longo prazo, menores taxas de juros e instituições financeiras mais sólidas. Essa é a questão apresentada por William Summerhill, quando afirma que o comprometimento brasileiro em honrar os direitos de propriedade dos credores da dívida pública não foi capaz de influenciar a formação de um mercado de capitais privado, que financiasse desde os fazendeiros decadentes do Vale do Paraíba fluminense até a formação de uma indústria propriamente nacional. ${ }^{21}$

O modelo de nações como Holanda, Inglaterra e Estados Unidos, cujas histórias de formação de dívidas nacionais foram bastante bem-sucedidas, seriam exemplos da necessidade de amplo desenvolvimento financeiro para haver crescimento econômico sustentável. ${ }^{22}$ No caso desses países, o serviço da dívida pública levou à criação de um mercado de capitais doméstico que, a longo prazo, pôde financiar seus respectivos avanços produtivos. Ao não constatar semelhante movimento para o caso brasileiro,

\footnotetext{
${ }^{19}$ SUMMERHILL, William, obra citada, p. 49.

${ }^{20}$ SUMMERHILL, William, Inglorious Revolution: Political Institutions, Sovereign Debt, and Financial Underdevelopment in Imperial Brazil. Yale University Press, 2015, p. 29.

${ }^{21}$ Ibidem, p. 09.

${ }^{22}$ SUMMERHILL, William, Inglorious Revolution: Political Institutions, Sovereign Debt, and Financial Underdevelopment in Imperial Brazil. Yale University Press, 2015, p. 09
} 
Summerhill coloca em xeque a análise institucionalista a respeito da ascensão das economias ocidentais; a credibilidade do governo para com suas próprias dívidas não necessariamente desembocou em desenvolvimento ou criou uma base institucional sólida para os negócios. $^{23}$

Ao longo deste trabalho, daremos forte importância ao aparecimento e desenvolvimento de uma rede de instituições no Brasil, cuja atuação mostrou-se fundamental para a consolidação do capitalismo no país. As companhias de seguros estão dentre essas instituições, bem como a legislação regulatória desse setor. De maneira bastante geral, pode-se afirmar que as explicações a respeito do desenvolvimento econômico e industrial brasileiro baseadas essencialmente no vazamento de capital do núcleo agrícola em direção à indústria explicam apenas uma parte do processo de formação do capital industrial nacional. Para além desse movimento, as relações capitalistas na periferia também se basearam em determinados arranjos institucionais que permitiram a ampliação dos ganhos de produtividade e da acumulação; os referidos arranjos institucionais, no entanto, permaneceram muito deficientes, e seus resultados, como bem sabemos, foram bastante distintos daqueles do centro. ${ }^{24}$

O objetivo dessa dissertação é, portanto, mostrar como a atividade seguradora no Brasil de então foi influenciada pela nova dinâmica do capitalismo global. Buscamos inserir e relacionar a atuação financeira das companhias de seguros ao contexto do final do século XIX e início do XX, época marcada pela intensificação dos circuitos de crédito e dívida.

\footnotetext{
${ }^{23}$ SUMMERHILL, William, obra citada, p. 05

${ }^{24}$ A respeito do desenvolvimento das instituições no ocidente capitalista, ver: NORTH, Douglas, \& THOMAS, Robert, The Rise of the Western World: a new economic history. Cambridge: Cambridge University Press, 1973.
} 


\section{Capítulo 1 - As companhias de seguro no Brasil nos marcos da primeira globalização}

No presente capítulo abordaremos a expansão do capital estrangeiro e o crescimento do investimento externo no Brasil entre os anos de 1889 e 1914, momento em que os laços capitalistas no país se estreitavam e a dimensão financeira da economia se desenvolvia. Essa expansão influenciou a composição dos investimentos externos no Brasil e também esteve por trás do fortalecimento das estruturas e relações financeiras desse momento. Além disso, buscaremos mostrar o quanto os referidos fluxos do capital eram determinantes para a adoção de determinadas medidas macroeconômicas, sujeitas à disponibilidade de cambiais no país. A vulnerabilidade do valor da moeda esteve estreitamente ligada aos circuitos monetários internacionais.

Também apresentaremos o processo de construção de uma legislação normativa para o setor de seguros no Brasil, e o quanto sua aplicação determinou o funcionamento das companhias, nacionais e estrangeiras, influenciando diretamente suas possibilidades de inserção, expansão e acumulação de capital.

\subsection{Legislação de seguros antes da Proclamação da República}

O sistema normativo para o setor de seguros em 1889 ainda era aquele voltado às empresas de sociedade anônima. Diferentemente dos países da Europa, que vinham constituindo suas legislações para a fiscalização das atividades de seguro, as empresas no Brasil, tanto nacionais como estrangeiras, eram obrigadas - como qualquer outra sociedade anônima - a remeter seus balanços anualmente às Juntas Comerciais. O governo reconhecia a existência de potencial perigo em manter um regime de grande liberdade para o setor, cujas possíveis quebras e fraudes teriam amplo impacto em outros setores da economia. Por manipularem poupanças alheias e serem credoras do Estado e de outras firmas, a necessidade de uma legislação específica para as companhias de seguros, bem como de um marco regulatório que vigilasse sua atuação, já era percebida como fundamental pelo governo; o processo para a instauração da legislação, no entanto, fez-se de forma bastante lenta, e a primeira lei específica para regulação do setor foi promulgada apenas em 1895 , como veremos no próximo capítulo. ${ }^{25}$

\footnotetext{
${ }^{25}$ BRASIL, Decreto no 29405 de setembro de 1895, Actos do Poder Legislativo, Rio de Janeiro, 1895, p.
} 17. 
Até que leis específicas fossem instituídas, companhias estrangeiras se valeram de limitada legislação para estruturar suas operações de acordo com as matrizes no exterior, transferindo seus fundos obtidos pelos prêmios cobrados e provocando evasão de divisas. ${ }^{26}$ Muitas operavam no Brasil de acordo com legislações estrangeiras; foi o caso da Mannheimer Versicherunggesselschaft, que em seu estatuto de funcionamento no Brasil, no ano de 1889, afirmou:

Emquanto o accionista eliminado não tiver satisfeito a importância da chamada, ser-lhehão applicadas ainda as disposições do art. 184 B do Código Commercial allemão. Só poderão ser entregues as únicas vias de letras depositadas por qualquer accionista omisso depois de cumpridas todas as obrigações que, segundo estes estatutos e as disposições $d o$ Código Commercial allemão, houver a favor da companhia. ${ }^{27}$

Ou ainda:

O balanço será organizado de acordo com os regulamentos do Código Commercial e com os princípios gradualmente estabelecidos pelas mais sólidas companhias alemãs. ${ }^{28}$

É possível verificar outros exemplos de aplicação de legislação estrangeira no Brasil durante a primeira década republicana. Em fevereiro de 1889, a companhia alemã Norddeutscher Lloyd foi autorizada a funcionar pelas autoridades do Império. Constituída como sociedade anônima e controlada por quatro acionistas donos de outras firmas em seu país de origem, constituiu-se a fim de estabelecer comunicação regular entre vapores, em comércio intra europeu ou transatlântico, além de cuidar do transporte de passageiros e cargas e da construção e fretamento de navios. ${ }^{29}$ A companhia de navegação instalouse no Brasil com o capital de 30.000.000 marcos, divididos em ações de 1000 marcos cada, e rapidamente engajou-se na realização e aceite de seguros marítimos e fluviais, os quais submetiam-se às leis da cidade de Bremen e aos regulamentos da Bremische SeeAssecuranz Gesellschaft e da Assecuranz Anstalt für die Obserweser. ${ }^{30}$ A companhia previa que em caso de prejuízo e impossibilidade de assegurar o valor de $10 \%$ do capital total nos fundos, haveria a imediata transferência de 5\% dos lucros líquidos anuais para

\footnotetext{
${ }^{26}$ ALVIM, Pedro. A intervenção do Estado no mercado de seguro privado. São Paulo: Edição de Manuais Técnicos de Seguro, 1980, p.58-9.

${ }^{27}$ BRASIL. Actos do poder executivo, 1889, p. 595 (destaques meus).

${ }^{28}$ BRASIL, Actos do poder executivo, 1889, p. 597.

${ }^{29}$ BRASIL, Decreto 10.195, Actos do poder executivo, 1889, p. 184.

${ }^{30}$ BRASIL, Decreto 10.195, Actos do poder executivo, 1889, p. 187.
} 
seu fundo de reserva. As mesmas regras valeriam para os fundos de renovação e de seguros, sendo este último necessário "para o cobrimento de avariaz, prejuízos e despesas". ${ }^{31}$

Cabe aqui uma breve reconstituição das origens das companhias de seguros no Brasil no período pré-republicano. As primeiras surgiram logo após a chegada da Corte Portuguesa ao Rio de Janeiro em 1808. Sua constituição era resultado do interesse de grupos locais, mas também de membros da Corte, agora estabelecida na cidade do Rio de Janeiro, de estimular as atividades comerciais no país. O comércio marítimo e os contratos dos seguros eram regulados pelo Tribunal do Comércio e pela Provedoria de Seguros, ambos instituídos em 1808 e baseados na legislação da Casa de Seguros de Lisboa. ${ }^{32}$ Em 1810, a colônia publicaria a doutrina Reflexões sobre o commercio de seguros, obra de José da Silva Lisboa (o Visconde de Cairú), que afirmava a importância do negócio para os rumos da sociedade: "O comércio de seguros, animando todos os outros, e por consequência a civilização, é sem dúvidas um dos mais beneméritos da humanidade". ${ }^{33}$

A doutrina não se desvinculava das diretrizes da legislação de Portugal, mas já demonstrava certa autonomia na formulação de princípios próprios, incorporando influências não somente lusas, mas também francesas, como do Marques de Condorcet, em sua Enciclopédia Metódica. ${ }^{34}$

Em 1808 foram criadas as companhias de seguro Boa Fé e Conceito Público e, em 1810, a Identidade. Eram empresas formadas por grupos locais e voltadas ao atendimento das demandas de seguro do comércio marítimo, respondendo ao típico perfil dos empreendimentos que seriam formados até meados do século XIX. Afinal, sendo uma economia essencialmente exportadora, ainda que a conjuntura das primeiras décadas dos oitocentos tenha sido de limitado crescimento econômico, eram os grupos mercantis exportadores e importadores quem respondiam por parte significativa da renda nacional.

Antes da promulgação do Código Comercial, em 1850, foram dezoito as companhias autorizadas a funcionar no país. Esse fato merece uma ressalva, todavia, pois

\footnotetext{
${ }^{31}$ BRASIL, Decreto 10.195, Actos do poder executivo, 1889, p. 185.

32 BOHRER, Saulo Santiago. Interesses seguros: As Companhias de Seguro e a Provedoria de Seguros do Rio de Janeiro (1810-1831). Niterói: UFF - dissertação, 2008.

${ }^{33}$ LISBOA, José da Silva. Reflexões sobre o commercio de seguros. Rio de Janeiro: Imprensa Régia, 1810, p.7.

${ }^{34}$ SAES, Alexandre Macchione; GAMBI, Thiago Fontelas Rosado, texto citado. Para o tema da história dos seguros, conferir os livros: ALVIM, Pedro. A intervenção do Estado no mercado de seguro privado. São Paulo: Edição de Manuais Técnicos de Seguro, 1980; MAGALHÃES, Raphael de Almeida. O mercado de seguros no Brasil. Rio de Janeiro: Funenseg, 1997 e ALBERTI, Verena (coord.). Entre a solidariedade e o risco: história do seguro privado no Brasil. Rio de Janeiro: FGV-RJ e Funenseg, 2001.
} 
o fato das empresas serem autorizadas a funcionar não significava que tivessem efetivamente entrado em atividade. ${ }^{35}$ Nas décadas entre a chegada da Corte e 1850 o Brasil alcançaria sua independência e, por isso, precisaria constituir uma legislação própria sobre o tema. O primeiro passo foi dado em 1831, quando decretou-se a lei que extinguia as provedorias de seguros do Império, estas que obedeciam ainda ao regime da Casa de Seguros de Lisboa. No entanto, foi somente com a promulgação do Código Comercial brasileiro de 1850, dedicando capítulo específico para o seguro marítimo, que o país passou a dispor de regulamento próprio. ${ }^{36}$ Eram anos de domínio dos saquaremas no comando da política Imperial brasileira, fase em que se constitui um arcabouço institucional fundado na ordem e na civilização. ${ }^{37}$

O Código Comercial significava, portanto, um marco institucional relevante para a economia nacional, definindo regras sobre o transporte e o comércio marítimo, sobre a abertura de companhias de sociedade anônimas, de empresas e de seguros, e sobre regras de quebras e falências, dentre outros negócios; vale destacar, no entanto, que o período marcava também uma tendência de retomada do crescimento econômico nacional passadas as primeiras décadas de instabilidade do Império pós-Independência. Seria o momento da abertura das primeiras estradas de ferro do país, da reorganização do sistema financeiro nacional e da centralização bancária via Banco do Brasil, sempre em meio à expansão da cultura do café, a base da riqueza econômica nas décadas seguintes. ${ }^{38}$ Apesar

\footnotetext{
35 Os dados para o período foram retirados de SAES, Alexandre Macchione; GAMBI, Thiago Fontelas Rosado. A formação das Companhias de Seguros na economia brasileira (1808-1864). História Econômica \& História de Empresas. Vol. 12, n. 2, jul. 2009. O levantamento das Companhias de Seguros naquele trabalho baseou-se nos decretos selecionados a partir da Relação de sociedades mercantis autorizadas a funcionar no Brasil, livro elaborado pelo Ministério do Trabalho, Indústria e Comércio, e pelo Almanack Administrativo, Mercantil e Industrial do Rio de Janeiro, o Almanack Laemmert. BRASIL, Sociedades Mercantis autorizadas a funcionar no Brasil: 1808-1946. Rio de Janeiro: Dep. Nac. de Indústria e Comércio, 1947 e Almanack Laemmert, Rio de Janeiro: Typ. Universal de Laemmert, 1844-65.

${ }^{36}$ BRASIL, Coleção das leis do Brasil. Rio de Janeiro: Typhographia Nacional, 1850. Cf. COSTA, Ricardo Cesar Rocha da. "A atividade de seguros nas primeiras décadas da República". ALBERTI, Verena (coord.). Entre a solidariedade e o risco: história do seguro privado no Brasil. Rio de Janeiro: FGV-RJ e Funenseg, 2001, p.24-5. Vale destacar que no caso do Código Comercial estava em jogo a construção de balizas para o funcionamento do setor, mas não de um sistema de intervenção no mercado de seguros, que seria pensado somente a partir de 1852, com uma legislação do estado do Massachusetts, disseminada posteriormente para outros países. Cf. ALVIM, Pedro. A intervenção do Estado no mercado de seguro privado. São Paulo: Edição de Manuais Técnicos de Seguro, 1980, p.46.

37 MATTOS, Ilmar. O tempo saquarema. A formação do Estado Imperial. São Paulo: Hucitec, 2004; GAMBI, Thiago Fontelas Rosado. O Banco da Ordem: política e finanças no Império brasileiro (18531866). São Paulo: Alameda, 2015.

${ }^{38}$ Para o crescimento econômico brasileiro do período, conferir Celso Furtado. Formação Econômica do Brasil. Rio de Janeiro: Fundo de Cultura, 1959. Para a importância do Código Comercial para os negócios no período, conferir Maria Bárbara Levy. A indústria do Rio de Janeiro através de suas sociedades anônimas. Rio de Janeiro: Editora UFRJ, 1994.
} 
do avanço institucional representado pelo Código Comercial de 1850, seu artigo 686 mostrava-se hostil em relação aos seguros de vida. ${ }^{39}$

Somente na década de 1850 , cerca de vinte companhias de seguro nacionais seriam autorizadas a funcionar, tendo como particularidade a formação das primeiras seguradoras destinadas aos seguros de incêndio, de vida e duas voltadas para o seguro de escravos. Até o ano de 1888, quando é abolida a escravidão no Brasil, notamos o funcionamento de ao menos onze companhias de seguros contra a mortalidade de escravos, todas com sede no Rio de Janeiro. A primeira de que se tem notícia é a Companhia Prosperidade, cuja duração foi bastante breve, tendo sido criada e fechada em 1845; as outras eram a Companhia de Seguros Previdência, que funcionou entre os anos de 1854 e 1859; a Companhia de Seguros Tranquilidade, de 1855 a 1858; Companhia Mútua de Seguros de vida de escravos, de 1857 a 1866; a Companhia de Seguros Marítimos e Terrestres Feliz Lembrança (depois Companhia Geral de Seguros União), de 1858 a 1873; Companhia de Seguros Útil Providência, que funcionou apenas durante o ano de 1860; Companhia de Seguros União Fluminense, de 1870 a 1871; a Companhia de Seguros Perseverança, de 1871 a 1888; a Companhia Garantidora de Vidas, de 1875 a 1876; a Companhia de Seguros Mútuos União, de 1875 a 1883; e, por fim, a Equitativa Brasileira, apenas durante $1877 .{ }^{40}$

De maneira geral, as companhias de seguro não eram tão numerosas se comparadas a outros ramos de indústrias e serviços, como as sociedades anônimas de comércio e de fazenda; tratavam-se, no entanto, de grandes empresas em volume de capital: conforme dados de Maria Bárbara Levy, as seguradas representavam 23,1\% do capital das sociedades anônimas transacionadas na Corte entre 1850-1865, atrás em volume de capital apenas do setor bancário e das estradas de ferro. ${ }^{41}$

Outra importante mudança em curso no período foi a chegada das primeiras empresas estrangeiras de seguros no país, uma tendência observável também em outros setores da economia brasileira, tanto em função da crescente renda exportadora nacional resultante do comércio cafeeiro, como também do maior interesse do capital estrangeiro

\footnotetext{
${ }^{39}$ BRASIL, Arquivo Público do Estado de São Paulo, Correio Paulistano, 20 de outubro de 1909, p. 20.

${ }^{40}$ PAYAR, André Javier Ferreira, A escravidão entre os seguros: as seguradoras de escravos na Província do Rio de Janeiro (1831-1888), 2012, 240 f. Dissertação (Mestrado em Direito). Faculdade de Direito, Universidade de São Paulo, São Paulo, 2012.

${ }^{41}$ LEVY, Maria Bárbara. A indústria do Rio de Janeiro através de suas sociedades anônimas. Rio de Janeiro: Editora UFRJ, 1994, p.56.
} 
pela periferia. ${ }^{42}$ Para regular minimamente a participação das empresas estrangeiras no setor de seguros, o governo promulgou dois decretos que obrigavam a apresentação de pedidos de autorização de funcionamento e aprovação dos estatutos das companhias estrangeiras - protocolo que era realizado com as seguradoras nacionais -, assim como exigia a publicação anual dos balanços das companhias autorizadas a funcionar. ${ }^{43}$

Entre as décadas de 1860 e 1890, as empresas estrangeiras que se instalaram no país eram fundamentalmente inglesas, nacionalidade igualmente dominante em setores como dos bancos, das companhias de navegação e das estradas de ferro. ${ }^{44}$ No caso das companhias de seguros seriam também observadas empresas portuguesas, compreensível pelo forte nexo comercial entre os dois países e pela maciça presença dos comerciantes portugueses, especialmente na cidade do Rio de Janeiro. Todavia, as empresas portuguesas não teriam a mesma participação no mercado quanto às alemãs, dotadas de representativa presença a partir da década de 1870, já apontando a uma tendência de diversificação da participação da nacionalidade do capital, mais comum nos primeiros anos do século $\mathrm{XX} .^{45}$

As duas primeiras companhias estrangeiras instaladas no Brasil, em 1862, foram a Companhia de Seguros Garantia e a Companhia de Seguros Fidelidade, ambas registradas em Portugal. No caso das sociedades inglesas, as primeiras a serem instaladas foram a Imperial Fire Insurance Company em 1863, a The Royal Insurance Company em 1864, e a Liverpool and London Insurance Company em 1866. A partir de então, o mercado antes dominado por empresários brasileiros passou a ser dividido com as companhias estrangeiras: um setor de baixo custo para a entrada e com alta lucratividade, favorável para uma primeira incursão no emergente mercado brasileiro. ${ }^{46}$

Até o início do funcionamento do Código Comercial de 1850, as companhias de seguros brasileiras funcionavam sobretudo a partir de instituições portuguesas; em outros

\footnotetext{
${ }^{42}$ RIPPY, Fred. British Investments in Latin America, 1822-1949. Arno Press, 1966; STONE, Irving. British Direct and Portfolio Investment in Latin America before 1914. The Journal of Economic History 37, no.3, Cambridge University Press, 1977; GUIMARÃES, Carlos Gabriel. A Presença Inglesa nas Finanças e no Comércio no Brasil Imperial. Os casos da Sociedade Bancária Mauá MacGregor \& Co. (1854-1866) e da firma inglesa Samuel Phillips \& Co. (1808-1840). São Paulo: Alameda, 2012.

${ }^{43}$ COSTA, Ricardo Cesar Rocha da. "A atividade de seguros nas primeiras décadas da República". ALBERTI, Verena (coord.). Entre a solidariedade e o risco: história do seguro privado no Brasil. Rio de Janeiro: FGV-RJ e Funenseg, 2001, p.26-7.

${ }^{44}$ CASTRO, Ana Célia. As empresas estrangeiras no Brasil, 1860-1913. Rio de Janeiro: Zahar, 1979.

${ }^{45}$ BRASIL, Sociedades Mercantis autorizadas a funcionar no Brasil: 1808-1946. Rio de Janeiro: Dep. Nac. de Indústria e Comércio, 1947.

${ }^{46}$ COSTA, Ricardo Cesar Rocha da. "A atividade de seguros nas primeiras décadas da República". ALBERTI, Verena (coord.). Entre a solidariedade e o risco: história do seguro privado no Brasil. Rio de Janeiro: FGV-RJ e Funenseg, 2001, p.28.
} 
casos, como dito acima, assistiu-se à aplicação de legislação estrangeira, referente às sedes das seguradoras vindas de fora. A organização de uma legislação nacional capaz de regular o funcionamento das companhias de seguros ocorrerá apenas após a instauração do regime republicano, que pretendemos apresentar no próximo capítulo.

A formulação da legislação de seguros durante a Primeira República naturalmente terá de responder às mudanças estruturais pelas quais o capitalismo central e periférico passava nesse período. Verifica-se para a época uma maior integração comercial e financeira em níveis globais; é neste contexto que a atuação das seguradoras deixou de se restringir à concessão de seguros marítimos e terrestres e passou aos poucos a incluir o financiamento do Estado via compra de títulos da dívida pública, aquisição de apólices privadas de outras firmas, concessão direta de crédito, entre outras atividades financeiras. A legislação reguladora do setor teve que ser repensada para se adaptar aos novos marcos do capitalismo.

\subsection{Expansão do capital estrangeiro e o crescimento do investimento externo no Brasil,} $\underline{1889-1914}$

Este capítulo apresentará o momento de transição da economia mundial no final do século XIX e início do XX, quando se assiste à passagem do capitalismo concorrencial ao monopolista e à expansão do capital financeiro. A despeito de termos identificado um setor de seguros nacional mais dinâmico que o estrangeiro, nos parece importante apresentar o funcionamento do capital externo no período em questão, a fim de delinearmos quais as condições às quais o capitalismo brasileiro obedecia e se inseria. Para tanto buscaremos reconstituir o debate acerca da primeira globalização do final do século XIX, bem como apresentar uma pequena análise teórica a respeito do crédito. As questões levantadas por esses debates, posteriormente, colaborarão para que se compreenda a dinâmica financeira das companhias de seguros.

Longe de se dedicarem unicamente à concessão de apólices e pagamento de sinistros, ao longo da segunda metade do século XIX as seguradoras se constituíram cada vez mais como instituições financeiras com ampla inserção no mercado de compra de títulos da dívida pública brasileira. Se até a década de 1880 temos uma predominância dessas sociedades no comércio e no ambiente mercantil, a partir de então constatamos a presença frequente dessas firmas no mercado de compra e venda de títulos, públicos ou particulares, bem como na concessão de crédito ao setor privado. 
Referindo-se ao período de gestação da produção cafeeira, Celso Furtado afirmou que "dificilmente um observador que estudasse a economia brasileira pela metade do século XIX chegaria a perceber a amplitude das transformações que nela se operariam no correr do meio século que se iniciava". ${ }^{47}$ Durante os anos de consolidação do Estado Nacional pós independência, a economia brasileira viveu momentos de estagnação e decadência; a preservação da unidade nacional parecia ser "o único resultado líquido desse longo período de dificuldades." 48

A baixa do preço do açúcar, cuja concorrência na economia-mundo capitalista 49 tornava-se mais intensa devido à ampla produção cubana e antilhana, levou à estagnação das exportações e à queda dos termos de intercâmbio brasileiros, afastando o país das linhas de expansão do comércio internacional. Considerando as escassas possibilidades de desenvolvimento via mercado interno, tem-se ideia do grau de dependência do jovem Estado brasileiro para com as economias centrais. Esse arrefecimento comercial em muito diminuiu a capacidade para importar e a arrecadação estatal foi comprometida, somandose à série de problemas o desequilíbrio fiscal. ${ }^{50}$ Sob este pano de fundo, era inexpressiva a entrada de capitais estrangeiros que estimulassem a economia doméstica, havendo pouco interesse por parte dos credores em adentrar em um ambiente estagnado e com dificuldade em arrecadar impostos. Os poucos empréstimos externos aos quais o governo teve acesso auxiliaram o financiamento do Estado e foram por ele invertidos de forma improdutiva no auxílio à falida lavoura açucareira. ${ }^{51}$

\footnotetext{
${ }^{47}$ FURTADO, Celso. Formação Econômica do Brasil. Rio de Janeiro: Fundo de Cultura, 1959, p. 133.

48 Idem, p. 133. Como contraponto à visão furtadiana a respeito das escassas possibilidades de desenvolvimento via mercado interno, tem-se a ideia apresentada por João Fragoso e Manolo Florentino acerca da "formação colonial tardia", período entre 1790 e 1840 marcado pela monopolização das atividades mais rentáveis do comércio atlântico por parte dos negociantes de grosso trato da colônia, dotados de ampla liquidez e de certa autonomia frente às flutuações do mercado internacional. FRAGOSO, João, FLORENTINO, Manolo, Arcaísmo como projeto: mercado atlântico, sociedade agrária e elite mercantil em uma economia colonial tardia. Rio de Janeiro: Civilização Brasileira, 2001, p. 20.

${ }^{49}$ A abordagem teórica da economia-mundo, cuja maior referência é o historiador norte americano Immanuel Wallerstein, apresenta um modelo de síntese do funcionamento capitalista, definido como sistema internacional de longa duração. Para o autor é impossível compreender a dinâmica do modo de produção capitalista fora de unidades de análise amplas, que incluam o mapa das trocas comerciais entre países e regiões. A análise da acumulação de capital no âmbito de Estados-nações, portanto, seria insuficiente, já que a economia-mundo capitalista seria formada por distintas estruturas de produção, bastante integradas e especializadas, e seu funcionamento necessariamente acarretaria em uma distribuição desigual do excedente por entre as partes do sistema. WALLERSTEIN, Immanuel, The rise and future demise of the world capitalist system: concepts for comparative analysis, in Comparative Studies in Society and History, Volume 16, Issue 4, (sept. 1974), 387-415,

${ }^{50}$ A respeito da importância da cobrança de impostos sobre importações, presente no Brasil desde os tempos do Império, Cf. CARVALHO, José Murilo de, Teatro de sombras: a política imperial. Rio de Janeiro: Civilização Brasileira, 2007, p. 269.

${ }^{51}$ FURTADO, Celso. Formação Econômica do Brasil. Rio de Janeiro: Fundo de Cultura, 1959, p. 134.
} 
A produção cafeeira constituiu-se, em meio ao referido contexto, como uma possibilidade de reinserção do Brasil nas cadeias do comércio estrangeiro. Apesar de plantado no país desde o início do século XVIII, o café só obteve efetiva inserção no mercado mundial quando as condições da economia-mundo assim permitiram; a partir da desorganização da produção açucareira na colônia francesa de São Domingos, o oeste paulista tornou-se região atraente ao cultivo do açúcar e assistiu-se à rápida ascensão de uma nova classe de senhores de engenho em São Paulo, cuja produção passaria a ser expressiva e em poucas décadas permitiria a formação de uma economia açucareira na província. $^{52}$

Apesar de ter permitido a recuperação do dinamismo econômico paulista, o açúcar não se constituiu como gênero de exportação capaz de inserir o país em uma nova etapa de desenvolvimento. O mercado açucareiro tornou-se aos poucos menos promissor, sobretudo devido à ascensão da produção em Cuba, beneficiada pelos baixos preços do frete rumo ao mercado norte americano, e ao enraizamento do açúcar de beterraba na Europa. ${ }^{53}$ Com menor necessidade de capitais que a plantação açucareira e contando com ampla disponibilidade do fator terra, o café aos poucos tornou-se o cerne da economia do Sudeste, e seus produtores utilizaram-se sobretudo da mão de obra e dos recursos ociosos que o país conheceu desde a desagregação da economia mineira. Com o passar dos anos a composição da mão de obra seria alterada, sobretudo a partir da década de 1890, após a Abolição e a chegada dos primeiros imigrantes.

A partir da expansão da economia cafeeira, cujos percalços de gestação foram acima brevemente descritos, o Brasil teve sua oportunidade de reinserção nas cadeias do mercado mundial. Aos poucos assistiu-se à consolidação de uma estrutura econômica suficientemente sólida para permitir a acumulação de capitais, a retomada da capacidade exportadora, o aumento das importações e a ampliação da base de arrecadação físcal. Após o período de gestação e ascensão do café no Brasil, a economia nacional encontravase relativamente atraente para que o capital estrangeiro buscasse por aqui possibilidades de investimento.

\footnotetext{
${ }^{52}$ WALLERSTEIN, Immanuel, obra citada, p. 137. A respeito da relação entre a escravidão e a economia cafeeira à época, cf. MARQUESE, Rafael de Bivar. Capitalismo, escravidão e a economia cafeeira do Brasil no longo século XIX. Saeculum, João Pessoa, v. 29, p. 289-321, 2013. PETRONE, Maria Thereza Schorer. A lavoura canavieira em São Paulo. Expansão e declínio (1765-1851). São Paulo: Difusão Europeia do Livro, 1968.

${ }^{53}$ WALLERSTEIN, Immanuel, The rise and future demise of the world capitalist system: concepts for comparative analysis, in Comparative Studies in Society and History, Volume 16, Issue 4, (sept. 1974), p. 135
} 
Desde a década de 1870 a relativa prosperidade da economia nacional, cuja base provinha majoritariamente do sucesso de suas exportações, coincidiu com o período de crise do capitalismo britânico. As condições produtivas, o mercado consumidor, de trabalho e de capitais passavam por significativa reorganização no período em questão; os efeitos indiretos dessas circunstâncias seriam rapidamente sentidos pelas nações periféricas.

Foi a partir da chamada Grande Depressão do século XIX que os países periféricos testemunharam o aprofundamento de suas relações financeiras com os centrais. A nova dinâmica econômica era resultante da entrada maciça de capital estrangeiro que, impossibilitado de se valorizar em suas nações de origem, encontrava oportunidades de reprodução nos mercados em formação na periferia. ${ }^{54}$ A escassa possibilidade de financiamento por parte das economias subdesenvolvidas fez da importação de capitais um mecanismo defendido pelas elites nacionais. ${ }^{55} \mathrm{~A}$ vinda deste capital, como empréstimo ou como investimento direto por meio da constituição de empresas, obedeceu à contínua expansão do centro em direção à periferia e aos mecanismos institucionais que facilitavam essas transações entre países, como o padrão ouro. ${ }^{56}$

Esta vinda de capital estrangeiro a partir da década de 1870 corresponde a um momento específico de reorganização do capitalismo ocidental, possível de ser compreendido indiretamente através da análise do perfil das companhias estrangeiras que aqui abriram filiais.$^{57} \mathrm{O}$ que pretendemos destacar, no entanto, são algumas das mudanças fundamentais desse período, entre elas a ampliação da função financeira de empresas que, inseridas no turbulento contexto de passagem do capitalismo concorrencial ao

\footnotetext{
${ }^{54}$ Para o debate da Grande Depressão do século XIX, conferir DOBB, M. A evolução do capitalismo. Rio de Janeiro: Editora Guanabara, 1987; SAES, Flávio \& SAES, Alexandre. História Econômica Geral. São Paulo: Saraiva, 2013; FEIS, Herbert, Europe, the world's banker (1870-1814).Clifton: Augustus Kelley, Reprint of Economic Classics, 1964.

${ }^{55}$ BASTOS, Pedro Paulo Zaluth, A dependência em progresso: fragilidade financeira, vulnerabilidade comercial e crises cambiais no Brasil (1890-1954). Campinas: UNICAMP. IE, 2001, p. 26.

${ }^{56}$ HOBSBAWM, Eric. A era dos impérios. São Paulo: Paz e Terra, 1989; CAIN, P.J e HOPIKINS, A.G. British imperialism: innovation and expansion, 1688-1914. Londres: Longman, 1993. POLANYI, Karl, A grande transformação. Rio de Janeiro: Campus, 2000; EICHENGREEN, Barry. A globalização do capital: uma história do sistema monetário internacional. São Paulo: Editora 34, 2007.

${ }^{57}$ Segundo Gustavo Franco: "O investimento direto estrangeiro parecia obedecer em maior escala às condições da economia internacional e ao estado dos principais mercados financeiros do que aos fatores de atração originados pela política econômica local, como as concessões de garantias de juro ou diferenciais de taxa de juros. Na verdade, havia uma correspondência bastante estrita entre as exportações de capital inglês para o mundo e para a América do Sul e os investimentos estrangeiros no Brasil, o que sugere a exogeneidade dos movimentos de capital estrangeiro para o Brasil, mas não afasta a possiblidade do Tesouro exercer algum controle sobre esses movimentos" FRANCO, Gustavo, Reforma monetária e instabilidade durante a transição republicana. Rio de Janeiro: BNDES, 1983, p. 40.
} 
monopolista, encontram-se cada vez mais envolvidas nas cadeias de concessão e obtenção de crédito.

Apesar dos países europeus contarem com redes de empréstimo bastante antigas e sofisticadas, consideraremos que o crédito concedido entre 1889 e 1914 diferencia-se das experiências anteriores por se dar em meio à consolidação da alta inovação tecnológica da chamada Segunda Revolução Industrial e da difusão de um padrão de consumo de massas correspondente às novas condições produtivas. O Brasil de então sofreu influências diretas desse processo e participou das cadeias de crédito internacional como devedor. O desenvolvimento das relações capitalistas no centro influenciou de maneira direta a participação local de firmas estrangeiras, mas não apenas; a atuação das companhias brasileiras também era invariavelmente afetada.

A intensificação das redes creditícias do período, no entanto, não deve ser classificada como equivalente a um processo de "financeirização" da economia, que justamente nesse momento passa por fortes expansões produtivas. O que podemos constatar para ess época é um aumento nos fluxos de mercadorias e capitais em larga escala e uma ampliação da dimensão financeira. A maior integração entre os continentes e a ampliação do volume de trocas são consequências de melhores condições de transporte que, por sua vez, influenciaram incisivamente a alocação de recursos das economias regionais e seus preços domésticos, além de terem contribuído para a convergência dos preços das mercadorias em uma escala global. ${ }^{58}$ Essa última seria característica fundamental na definição de uma economia globalizada tal qual usamos o termo hoje em dia; consideraremos que a globalização das mercadorias e do crédito começou na década de 1870 .

A partir dessa data, o cerne das exportações dos países ricos não estava mais em bens de consumo não duráveis e sim em máquinas e bens intermediários, além de capital monetário e investimentos diretos. Os efeitos daí decorrentes são facilmente identificáveis na economia brasileira de então. Essa mudança no perfil das exportações responde ao excesso de liquidez das companhias, sobretudo europeias, cujo bom

\footnotetext{
${ }^{58}$ WILLIAMSON, Jeffrey, O'ROURKE, Kevin, "When did globalization begin?" in National Bureau of Economic Research, Cambridge, Massachussets, abril 2000, p. 18. Para os autores, um amplo volume de trocas não é o suficiente para classificar uma economia como globalizada; para tanto faz-se necessário conferir a convergência de preços das mercadorias em uma escala global. Afirmam os autores que preços convergentes foram verificados entre 1870 e 1913 em Londres, Buenos Aires, Montevideo e Rio de Janeiro.
} 
funcionamento se via ameaçado pelas escassas possibilidades de investimento e absorção do capital.

Essa condição afetou sobretudo a Inglaterra, mas, como dito acima, teve impacto relevante em outras economias europeias entre os anos de 1873 e 1896. A crise interrompeu o círculo virtuoso entre produção e consumo ao qual as economias centrais estavam submetidas durante grande parte do século XIX; segundo Fernand Braudel, a aventura da revolução industrial teria criado um excesso de capital monetário dificilmente absorvível. ${ }^{59} \mathrm{O}$ processo de reorganização do capitalismo do final do século XIX levou à formação de um sistema de expansão econômica cuja influência sobre o desenvolvimento da periferia foi bastante profunda.

As condições de formação e sustentação de uma demanda interna capaz de absorver os novos níveis de produção foi tema tratado por diferentes correntes teóricas. Marx se referiu ao "credo característico do fabricante inglês", isto é, a incapacidade dos industriais da segunda metade do século XIX de compreenderem o fenômeno da superprodução. Nas suas palavras:

A rapidez diariamente crescente, com que se pode atualmente aumentar a produção em todos os domínios da grande indústria, confronta com a lentidão sempre maior da expansão do mercado para essa produção ampliada. O que aquela produz em meses, este quase não pode absorver em anos. ${ }^{60}$

ou então:

A razão última de todas as crises reais é sempre a pobreza e a restrição ao consumo das massas em face ao impulso da produção capitalista a desenvolver as forças produtivas como se apenas a capacidade absoluta de consumo da sociedade constituísse seu limite. ${ }^{61}$

A incapacidade da demanda em absorver os ciclos de superprodução esteve, de fato, por trás do processo de reorganização do capitalismo a partir da segunda metade do século XIX. Conforme desenvolviam-se os monopólios e os conglomerados nacionais, capazes de se expandirem desde que associados aos aparelhos estatais, formavam-se estruturas de acesso ao crédito bastante cosmopolitas e abrangentes. Estas redes, que interligavam distintas nações ocidentais, estimularam o que Karl Polanyi chamou de

\footnotetext{
${ }^{59}$ ARRIGHI, Giovanni, O Longo Século XX. São Paulo: Unesp, 1996, p. 5.

${ }^{60}$ MARX, Karl, O Capital, Livro III, Tomo I, p. 332

${ }^{61}$ Idem, O Capital, Livro III, Tomo II, cap. 30, p. 24
} 
"internacionalismo dos Rotschilds", isto é, a organização de um sistema de finanças independente e sem compromissos diretos com nenhum governo. ${ }^{62}$

Segundo Polanyi, entre o último terço do século XIX e primeiro terço do XX as hautes finances funcionaram como o "elo principal entre a organização política e a econômica do mundo"; longe de terem sido constituídas como instrumento de paz, acabaram, no entanto, por cumprir com este papel, ao lado de outras quatro instituições cuja existência permitiu o sucesso do chamado "concerto da Europa": o equilíbrio de poder, o Estado liberal, o padrão ouro internacional e o mercado auto regulável. ${ }^{63}$ Os portadores de títulos governamentais seriam os primeiros prejudicados com a eclosão de uma guerra entre as potências europeias; por outro lado, se beneficiavam com a existência do padrão ouro e com o bom funcionamento de um sistema monetário internacional, capazes de regular o câmbio e a estabilidade da moeda de diferentes países. Segundo Polanyi: "o sistema de equilíbrio de poder foi uma superestrutura erigida sobre o padrão ouro e parcialmente nele fundamentada; o estado liberal foi, ele mesmo, uma criação do mercado auto regulável." 64

Com o conflito eminente no continente europeu sendo "empurrado para lugares mais profundos sob a superfície da amabilidade" ${ }^{65}$, essas instituições de fato garantiram a paz europeia entre os anos de 1815 e 1914. A tensão entre o nacionalismo e o cosmopolitismo tornava-se mais estreita conforme expandiam-se as exportações de capital; ao mesmo tempo em que buscavam ampla expansão para fora das suas fronteiras nacionais, os países europeus as reforçavam constantemente. A relação estreita entre o capital e o Estado, que incentivava a ampliação de fronteiras sob uma forte carga ideológica, militar e nacionalista, dava à expansão dos trustes nacionais de Estado significativa identidade nacional.

Foi neste contexto que a expansão dos países do centro foi considerada como uma reação nacionalista ao padrão ouro e às instituições a ele ligadas. Os nacionalismos exacerbados do final do século XIX, bem como a retomada de determinadas estruturas de organização econômica pouco condizentes com o liberalismo dominante na Europa até

\footnotetext{
62 POLANYI, Karl, A grande transformação. Rio de Janeiro: Campus, 2000, p. 26. Nas palavras do autor: "Os Rotschilds não estavam submetidos a nenhum governo; como família, eles incorporavam o direito abstrato do internacionalismo; sua lealdade era para com uma firma, cujo crédito se tornara o único elo supranacional entre o governo político e o esforço industrial numa economia mundial em rápido crescimento."

${ }^{63}$ POLANYI, Karl, A grande transformação. Rio de Janeiro: Campus, 2000, p. 17.

${ }^{64}$ Ibidem, p. 18.

${ }^{65}$ Ibidem, p. 27
} 
então (como exemplo, pode-se citar os monopólios e o protecionismo estatal), teriam despontado em oposição ao sistema monetário internacional. ${ }^{66} \mathrm{O}$ constrangimento que o padrão ouro impunha à liberdade das políticas monetárias, cambiais e fiscais estimulou a ascensão posterior de políticas de proteção ao mercado interno e tentativas de conquista de mercados externos. A reação ao padrão ouro se fez via adoção de medidas protecionistas, e estas se tornaram opções para amortecer o impacto doméstico dos ciclos monetários. ${ }^{67}$

Segundo os dados apresentados por Jeffrey Williamson e Kevin O’Rourke, entre o ano de 1870 e a Primeira Guerra Mundial as tarifas de importação da economia atlântica não conheceram quedas, tendo na realidade sofrido relativo aumento em algumas regiões. A permanência ou aumento das tarifas de importação foi interpretada pelos autores como uma reação à ampla integração dos mercados internacionais, devido sobretudo à forte diminuição dos custos de transporte via navios à vapor e novos incrementos tecnológicos. ${ }^{68}$

Consideraremos, no entanto, que o protecionismo não apenas exerceu expressivo papel geopolítico para que a expansão financeira dos países do centro prosperasse, como também estimulou, no caso europeu, a produção industrial artificial e sem mercado. Marx tratou a respeito das possibilidades de crises de superprodução no terceiro volume do Capital:

(...) e acresce a política de proteção aduaneira, mediante a qual cada nação industrial se fecha contra as demais e principalmente contra a Inglaterra, aumentando e ainda de modo artificial a capacidade interna de produção. As consequências são superprodução crônica geral, preços deprimidos, lucros em baixa e até mesmo em completa desaparição. ${ }^{69}$

As condições técnicas à época do livre comércio da primeira metade do século XIX não permitiam que as empresas acessassem os meios de produção de outro país; $o$ principal agente da internacionalização era o comércio. A partir da década de 1870, por outro lado, o capital estrangeiro foi capaz de comandar empreendimentos e investimentos diretos na periferia, pois o alto nível de maturidade tecnológica, bem como a ampla

\footnotetext{
${ }^{66}$ Em A Grande Ilusão, escrita em 1910, Norman Angell apresenta a guerra imperialista entre as nações como um fenômeno anacrônico vis a vis a capacidade mundial em obter os mesmos resultados de apropriação do excedente via comércio, e não via espoliação. ANGELL, Norman, A Grande Ilusão. São Paulo: Editora Universidade de Brasília, 2002, p. 11.

${ }^{67}$ BASTOS, Pedro Paulo, obra citada, p. 34.

${ }^{68}$ WILLIAMSON, Jeffrey, O’Rourke, Kevin, “When did globalization begin?” in National Bureau of Economic Research, Cambridge, Massachussets, abril 2000, p. 17.

${ }^{69}$ MARX, Karl, O capital. Crítica da economia política. Volume III. São Paulo, Abril Cultural, 1985c, Tomo I, p. 332 (destaque meu)
} 
disponibilidade de liquidez, tornaram possível às empresas outro tipo de extração de excedente, bastante diverso daquele que marcou o liberalismo dos anos anteriores. Citamos a esse respeito trecho emblemático do Capital:

$\mathrm{Na}$ Inglaterra, há constante acumulação de riqueza adicional, que tem a tendência a assumir finalmente a forma de dinheiro. Mas, depois do desejo de ganhar dinheiro, o desejo mais premente é o de livrar-se dele de novo mediante qualquer espécie de investimento que traga juros ou lucro; pois o dinheiro como tal nada proporciona. Se, portanto, simultaneamente com esse afluxo de capital excedente não há expansão gradual e suficiente campo de aplicação para ele, estaremos necessariamente expostos a acumulações periódicas de dinheiro à procura de aplicação, as quais, conforme as circunstâncias, serão mais ou menos importantes. ${ }^{70}$

David Harvey se referiu aos recorrentes episódios de "ajustes espaciais" aos quais o capital do centro recorreu, em processos cuja consequência era a constante realocação geográfica do excedente. ${ }^{71}$ Esse excedente poderia existir na forma monetária, como mercadoria ou mesmo na forma de capacidade produtiva, e o Brasil do período em questão conheceu todas as referidas formas de excedente do centro. ${ }^{72}$ Cabe aqui compreendermos que, em um ambiente de mudanças significativas no capitalismo europeu, apenas as grandes empresas e monopólios dotados de boas relações com os governos tinham a possibilidade de usufruir dos diferenciais geográficos que a expansão oferecia. $^{73}$

O Brasil pode ser considerado como exemplo de região periférica cujos laços comerciais e financeiros com os países do centro do capitalismo em muito se intensificaram entre meados do século XIX e início do XX. A inserção comercial brasileira à época cresceu, sendo possível observar maior abertura e um aumento de 3,2\% na razão exportações/PIB entre 1870 e 1900; sua participação sobre o conjunto comercial mundial, no entanto, ainda era pequena, tendo o país representado apenas $1 \%$ do todo no

\footnotetext{
${ }^{70}$ MARX, Karl, O capital. Crítica da economia política. Volume III. São Paulo: Abril Cultural, 1985c, Tomo I, cap. 26, p. 315 (destaque nosso)

${ }^{71}$ Cabe aqui destacarmos a diferenciação realizada por David Harvey entre excedente e excesso de excedente; o excedente é uma categoria fundamental para o capitalismo, sem o qual não há nem mesmo possibilidade de formação de um ciclo de reprodução. A formação de excesso de excedente, no entanto, é perniciosa para o desenvolvimento do capital. HARVEY, David, A produção capitalista do espaço. São Paulo: Annablume, 2005, p. 136.

${ }^{72}$ Idem, p. 160

${ }^{73}$ HARVEY, David, A produção capitalista do espaço. São Paulo: Annablume, 2005, p. 143
} 
ano de $1913 .^{74}$ No que diz respeito à participação no conjunto dos investimentos estrangeiros, no entanto, o Brasil do início do período republicano teve papel mais expressivo e caminhou para uma razoável diversificação. O estoque total de capital estrangeiro no país, formado por investimentos franceses, ingleses, alemães e norteamericanos, representava cerca de 30\% do total para a América Latina (cerca de 524 milhões de libras). O serviço de capitais, categoria bastante rígida no balanço de pagamentos nacional, aumentou em comparação à quantidade das exportações, de 9,4\% em 1861-64 para $12,1 \%$ em 1880-92. ${ }^{75}$

Entre 1889 e 1914, as empresas que migraram para o país variaram em termos de origem e setor de atuação. $\mathrm{O}$ crescimento da economia exportadora demandava melhores serviços públicos, incrementos urbanos e reformas. Conforme se desenvolviam as indústrias naval e ferroviária, os riscos inerentes ao alto volume de transações e investimentos cresciam e as companhias de seguros se expandiam. A respeito da relação entre as mudanças estruturais pelas quais a economia brasileira passava e a inserção das companhias de seguros, reproduzimos um trecho publicado pelo periódico norteamericano editado no Brasil, The Rio News, em janeiro de 1891:

Não interessando se a companhia é mutuária ou joint-stock (...) é considerado sempre necessário aos homens de negócio segurar suas propriedades contra riscos de incêndios e destruição de navios, e aos maridos e pais que segurem sua vida para o benefício de suas famílias. O risco de perda e indigência deve ser assumido por uma associação organizada, para que esses pesos deixem de pesar de maneira tão pesada naqueles tão pouco aptos a suportarem. (...) Talvez os riscos de acidentes não sejam tão grandes por aqui do que em países mais velhos e populosos, mas mesmo assim são frequentes o suficiente para demandar proteção e ajuda as quais uma boa companhia de seguros pode prover. Com melhores meios e comunicação, as viagens estão aumentando rapidamente; e com o rápido desenvolvimento de indústrias domésticas, uma nova e muito importante classe de riscos vem rapidamente a tona. A vida fácil e protegida dos tempos de outrora está desaparecendo, e no seu lugar teremos aquele febril e tumultuado estado de existência que sempre acompanha todo repentino desenvolvimento comercial e industrial. Uma

\footnotetext{
${ }^{74}$ FRANCO, Gustavo, "A primeira década republica", em ABREU, Marcelo de Paiva (org.), A ordem do progresso. Dois séculos de política republicana. Rio de Janeiro: Editora Campus, 1995, p. 12

${ }^{75}$ FURTADO, Celso, Formação Econômica do Brasil, Rio de Janeiro: Editora Fundo de Cultura, 1959, p. 189. Segundo o autor, grande parte dos capitais exportados no século XIX eram empréstimos públicos ou investimentos no setor privado com garantias de juros, daí a rigidez na conta de capitais dentro da balança de pagamentos brasileira.
} 
companhia de seguros de acidentes, se empregar seus fundos discretamente e com bom julgamento, pode ser de benefício incalculável para este país (...). ${ }^{76}$

Os investimentos dominantemente voltados à construção de estradas de ferro deram espaço ao crescente número de companhias de serviços urbanos e de seguros: as últimas representaram 30,7\% do capital aportado entre 1886-1896. ${ }^{77}$ No período compreendido entre 1897 e 1902, a participação das companhias de seguros e das empresas de serviços públicos atingiu cerca de $80 \%$ do investimento total, 19,2\% representado apenas pelas seguradoras. Os aportes de capital em outras áreas foram $36,7 \%$ de ferrovias, $10 \%$ de empresas de iluminação e transporte e 5,3\% de portos. ${ }^{78}$

Segundo Ana Célia Castro, a alta lucratividade, o pequeno risco e os pequenos recursos requeridos para a abertura de companhias de seguros estimularam a vinda de investidores estrangeiros "marginais", como alemães e portugueses, ao Brasil do final do século XIX e início do XX. Acrescentamos que as companhias de seguros, assim como os bancos, possuem em comum o fato de trabalharem com o capital de terceiros; os recursos que mobilizam e administram são a base de seu negócio, e para seu funcionamento não há necessidade de importação de maquinaria e bens intermediários. Essas condições ao certo estimularam a vinda de seguradoras de diferentes nacionalidades para o Brasil, mas o setor permaneceu amplamente dominado pelo capital inglês. ${ }^{79}$

Seguindo a tendência de diversificação dos setores com investimentos estrangeiros, a predominância inglesa também apresentou queda relativa na década de 1890. A partir de então constatou-se maior entrada do capital alemão, francês e norteamericano, cuja ascensão se deu em meio à chamada Segunda Revolução Industrial. ${ }^{80}$ Em todo caso, apesar da última década do século XIX ser marcada por essa perda relativa de posição do capital inglês, a inserção financeira do país na economia brasileira, em termos

\footnotetext{
${ }^{76}$ BRASIL, The Rio News Rio de Janeiro: A. J. Lamoureux, 06 de janeiro de 1891, p. 03. (destaques meus)

${ }^{77}$ CASTRO, Ana Célia, As empresas estrangeiras no Brasil, 1860-1913, Rio de Janeiro: Zahar Editores, 1979, p.61.

${ }^{78}$ CASTRO, Ana Célia, obra citada, p.71.

${ }^{79}$ Ibidem, p. 35.

80 "[entre 1886 e 1896] No plano internacional, o processo de concentração do capital, de crescente monopolização das atividades econômicas, é acompanhado de uma verdadeira revolução tecnológica liderada por novos setores que tem à frente as chamadas indústrias elétricas e certos ramos recém surgidos da química pesada. Enquanto a expansão do capital à escala internacional esteve baseada na construção de ferrovias e na indústria naval, a Inglaterra deteve uma posição de liderança entre as nações industriais. Durante as décadas de 70 e 80 do século XIX, por motivos amplamente conhecidos, a Inglaterra perde terreno em face dos avanços tecnológicos que acompanha, o surgimento dessas novas industrias. É justamente essa "segunda revolução industrial" que imprime decisivo impulso ao movimento de concentração do capital, o qual se expressa, por exemplo, no surgimento de gigantescas empresas industriais." Ibidem, p. 56
} 
absolutos, continuou sendo expressiva: os Rothschilds, por exemplo, continuariam como os fiadores da dívida externa brasileira, assim como os bancos e as companhias de seguros inglesas permaneceriam com representativo papel nos negócios realizados no Brasil. As firmas inglesas continuaram a entrar no país, mas em proporções relativas menores àquelas de 1860 .

Citaremos como exemplo dessa permanência de migração rumo ao Brasil o caso da britânica Atlas Assurance Company, que recebeu autorização para funcionar no Rio de Janeiro em 1898. Formada em Londres em 1808, quase um século antes de sua chegada no Brasil, a companhia concedia seguros de vida, contrafogo e para o pagamento de anuidades. Em 1890 passou por ampla reestruturação, e o valor subscrito para formação de seu capital importou na quantia de 1 milhão e duzentas mil libras. Tais pagamentos foram feitos por diferentes banqueiros britânicos. ${ }^{81}$

Era aceito que o referido capital social de 1 milhão e duzentas mil libras fosse aumentado, se assim julgasse conveniente a Assembleia Geral; o aumento de capital poderia ser realizado via subscrição de pessoas particulares, acionistas ou não da companhia em ações de 50 libras cada. O capital social da firma também poderia ser reduzido. ${ }^{82}$

Ao delimitar mais especificamente seus objetivos, a Atlas Assurance Company afirmou em seu estatuto conceder seguros contra perda ou danos causados por incêndios, relâmpagos, tormentas, terremotos e explosões sobre casas e bens de qualquer natureza. Em relação aos seguros de vida, as apólices referiam-se não apenas à morte dos segurados, mas também a ferimentos, acidentes, nascimentos e até mesmo a "falta de nascimentos de filhos." Propunha-se também a adquirir os negócios de quaisquer outras sociedades, bem como ampliar sua atuação para além do Reino Unido. ${ }^{83}$

As atividades fora do Reino Unido, em "colônias, dependências ou Estados estrangeiros", seriam fiscalizadas pelo Conselho de Diretores. Estes últimos decidiriam pela procedência ou não do envio de recursos dos depósitos ou reservas para as filiais em locais estrangeiros. Os fundos e bens sociais da companhia que não tivessem aplicação e não fossem necessários para "atender aos reclamos dos segurados" teriam seu destino escolhido pelo Conselho de Diretores. Os saldos foram investidos sobretudo em títulos e valores do Reino Unido, Grã-Bretanha ou Índia. São citados como exemplo de emprego

\footnotetext{
${ }^{81}$ BRASIL, Actos do Poder Executivo, 1898, p. 572.

${ }^{82}$ Ibidem, p. 574

${ }^{83}$ BRASIL, Actos do Poder Executivo, 1898, p. 579
} 
dos fundos os títulos do Tesouro do Reino Unido, obrigações ou qualquer valor cujos juros fossem garantidos pelo Parlamento, pelo Banco da Inglaterra, pelo Metropolitan Board of Yorks ou London County Council, valores hipotecários, ações de qualquer companhia ou corpo público provincial, municipal ou local de autoridade do Reino Unido, Grã-Bretanha ou Índia, além das colônias e dependências. No que diz respeito à participação e compra de terras e bens imobiliários, a Companhia investia apenas em propriedades "livres de emphyteuses de senhorio ou arrendamento por qualquer numero de annos, ou outro feudo." 84

Interessante notar como o trecho acima expõe a preocupação em se estabelecer compromissos com estruturas econômicas dotadas de relações de produção relativamente modernas; o desenvolvimento dessas relações no final do século XIX inglês era particularmente evidente. Quaisquer que fossem os resquícios de relações feudais na terra ou no trabalho, estes não poderiam interferir na constituição de uma companhia "moderna", baseada nos princípios do mercado. ${ }^{85}$ Em 1893, na revisão pela qual passou o estatuto da Atlas Assurance Company, foi alterada, dentre todas suas resoluções anteriores, a perspectiva de investir em títulos públicos, ações de companhias privadas e valores hipotecários apenas do Reino Unido e da Índia; no lugar de apenas essas localidades, as possiblidades de expansão da sociedade passam a incluir "qualquer paiz estrangeiro, incluindo os Estados Unidos da America e todos seus Estados, Districtos, Territorios ou Protectorados." ${ }^{16}$

Essa foi a tendência de transformação da economia britânica na segunda metade dos oitocentos, quando sua balança comercial, apesar de deficitária, era amplamente compensada por superávits na conta de serviços e capitais. Vale dizer que parte considerável do resultado positivo da balança de serviços inglesa era devida aos serviços de empresas. ${ }^{87}$

De fato, quando perdeu espaço na produção de mercadorias para novas potências como EUA e Alemanha, a Inglaterra dedicou-se mais à exportação de capitais e serviços; muitas firmas britânicas assumiram a função de transportadoras, comercializadoras e intermediárias. Segundo Hobsbawm "suas finanças triunfaram, e seus serviços (...) tornaram-se mais indispensáveis. $\mathrm{Na}$ verdade, se em algum momento Londres foi o

\footnotetext{
${ }^{84}$ BRASIL, Actos do Poder Executivo, 1898, p. 579

${ }^{85}$ BRASIL, Actos do Poder Executivo, 1898, p. 596.

${ }^{86}$ BRASIL, Actos do Poder Executivo, 1898, p. 596, p. 604.

${ }^{87}$ HOBSBAWM, Eric, Da revolução industrial inglesa ao Imperialismo. Rio de Janeiro: Editora Forense, 2000 .
} 
verdadeiro eixo econômico do mundo - e a libra esterlina, seu alicerce -, isso foi entre 1870 e $1913 .{ }^{\prime \prime 8}$

Aos poucos França e Alemanha também passam a ter contas externas em situação equivalente à inglesa. Os superávits passam a ser cada vez mais obtidos a partir das chamadas rendas invisíveis, isto é, seguros, juros, dividendos, fretes e serviços. Esses ganhos cresciam em relação à renda com a exportação de mercadorias e compensavam os contínuos déficits na balança comercial. Se a Inglaterra sofreu com tais déficits ao longo de todo o século XIX, a França o fez a partir da década de 1870, e a Alemanha a partir de $1880 .{ }^{89}$

À época as condições para a acumulação capitalista passavam por significativos processos de transformação. Em maio de 1905, a Academia de Comércio do Rio de Janeiro, órgão de consulta do governo sobre assuntos comerciais e industriais, anunciou que o Brasil participaria do Congresso Internacional de Expansão Econômica Mundial, reunião convocada pelo governo da Bélgica para o ano de 1907. Para tanto a Academia do Rio de Janeiro pretendia realizar, em julho de 1905, o Congresso Brasileiro de Expansão Econômica, isto é, uma versão doméstica do referido evento estrangeiro. Para tanto enviaram uma carta oficial, transcrita nos principais jornais do Rio de Janeiro e São Paulo, convocando os presidentes de províncias a preencherem um formulário com perguntas a respeito de sua região. O objetivo nos parece bastante claro: explicar as condições brasileiras do início do século ao capital estrangeiro interessado em novos negócios. Segundo o próprio documento oficial do governo brasileiro:

(...) prestarei, assim, valioso concurso para o feliz exito do projectado Congresso Internacional de Expansão Economica Mundial que, segundo mostram seus organizadores na circular junta, vem abrir novos e largos horizontes à evolução economica e social do Brasil. ${ }^{90}$

Dentre as perguntas enviadas aos presidentes de províncias, citamos os questionamentos acerca do número de escolas primárias gratuitas, com programa de feição prática e útil, em cada Estado; se havia gratuidade no ensino prático de agricultura, indústria, comércio, artes e ofícios; qual a quantidade de terras incultas que ainda

\footnotetext{
${ }^{88}$ ARRIGHI, Giovanni, obra citada, p. 267

${ }^{89}$ BASTOS, Pedro Paulo, obra citada, p. 31

${ }^{90}$ BRASIL, Correio Paulistano, Arquivo Público do Estado de São Paulo, 02 de junho de 1905, p. 02.
} 
existiam, a que lavouras se prestavam, quão longe estavam dos portos de mar e estradas de ferro; qual a quantidade e qualidade de matérias primas de cada região; quantas estradas de ferro e linhas de navegação existiam e qual sua extensão quilométrica; quais impostos e tarifas em vigor; qual a política de atração de imigrantes; e, por fim, o formulário questiona se havia instituições de previdência e assistência, como caixas econômicas, seguros, bancos regionais, pensões, aposentadorias, postos médicos, asilos e hospitais. ${ }^{91}$

A partir do referido questionário notamos como o capital estrangeiro buscava investir em ambientes minimamente regulados, com a existência de instituições financeiras básicas e uma estrutura que auxiliasse a produção. ${ }^{92}$ As más condições do Encilhamento, a ser discutido mais adiante, haviam afastado capitais e investimentos do país, que aos poucos retornavam conforme a inflação cedia e o câmbio se valorizava; quando, em 1906, a crise do Encilhamento de fato havia ficado para trás, a presença do capital estrangeiro no Brasil aumentou.

Naquele mesmo ano de 1906, o presidente Rodrigues Alves sancionou projeto de lei que reconhecia os diplomas conferidos pela Academia de Comércio do Rio de Janeiro, fundada em 1902, e pela Escola Prática de Comércio do Estado de São Paulo. A primeira instituição mantinha um curso de formação de agentes consulares, funcionários do Ministério das Relações Exteriores, chefes de estabelecimentos bancários e de grandes empresas comerciais, e funcionários e atuários de companhias de seguros; o curso era composto por expressiva variedade de disciplinas, dentre elas geografia comercial e estatística, história do comércio e da indústria, tecnologia industrial e mercantil, direito comercial e marítimo, economia política, ciências das finanças, contabilidade do Estado, direito internacional, história da diplomacia, história dos tratados e correspondência diplomática, alemão, italiano, espanhol, matemática superior e contabilidade mercantil comparada. ${ }^{93}$ A diversificação dos cursos da Academia de Comércio do Rio de Janeiro refletia a realidade cada vez mais complexa da economia nacional, que exigia a formação mais específica de quadros que quisessem se inserir como funcionários de companhias e empresas.

Muito se discutiu a respeito dos benefícios e desvantagens que a entrada do capital estrangeiro proporcionou ao Brasil. Em Grã-Bretanha e a modernização do Brasil, o

\footnotetext{
${ }^{91}$ BRASIL, Correio Paulistano, Arquivo Público do Estado de São Paulo, 02 de junho de 1905

${ }^{92}$ CASTRO, Ana Célia, obra citada, p. 90.

${ }^{93}$ BRASIL, Correio Paulistano, Arquivo Público do Estado de São Paulo, 16 de janeiro de 1905, p. 01. 
historiador britânico Richard Graham defendeu que a vinda de recursos, mão de obra, máquinas e know how inglês teria sido fundamental para a modernização brasileira; a oposição entre os interesses britânicos e a industrialização nacional seria para o autor uma proposição falsa, e o incremento da indústria local foi algo almejado pelos próprios ingleses. Como caso emblemático, Graham cita os proprietários britânicos de moinhos de trigo, em sua maioria contrários à importação de farinha pronta que concorresse com a produzida aqui. ${ }^{94}$

De fato, se considerarmos a entrada de capital estrangeiro no final do século XIX e início do XX como exemplo de investimentos externos diretos, a modernização da produção industrial local, mesmo que por mãos estrangeiras, tornou-se uma realidade. Ao se interessar pelo domínio dos meios de produção de uma determinada região periférica, para além da simples extração de excedente via comércio, a entrada do capital estrangeiro poderá levar a algum grau de desenvolvimento da região em questão; afinal, como já constatamos, a partir de determinado momento da complexificação do capitalismo no centro, não mais são exportados apenas bens de consumo não duráveis, mas também máquinas e bens intermediários. Segundo Giovanni Arrighi, o investimento externo direto permite que o protecionismo na região periférica seja algo desejável pelos países exportadores de capital. ${ }^{95}$

Outros autores corroboraram com a visão de que o capital estrangeiro não poderia nunca se interessar pela industrialização dos países fora do centro, e sim apenas pela sua subordinação primária. ${ }^{96}$ Em territórios cuja modernização era comandada por recursos estrangeiros poderia haver, no máximo, desenvolvimento dependente. Segundo Celso Furtado, a entrada da empresa estrangeira não poderia alterar a estrutura societária local pois a massa de lucros gerada não se vinculava e não se integrava à economia. Nas suas palavras:

A estrutura econômica da região onde penetrou a empresa capitalista não se modifica necessariamente como consequência da penetração. Apenas uma reduzida fração da mão de obra disponível é absorvida pela empresa forânea; os salários pagos a essa mão de obra não são determinados pelo nível de produtividade da empresa, e sim pelas condições de vida prevalecentes na região. ${ }^{97}$

\footnotetext{
${ }^{94}$ GRAHAM, Richard, Grã-Bretanha e modernização do Brasil, São Paulo: Editora Brasiliense, 1973, p. 146

${ }^{95}$ ARRIGHI, Giovanni, obra citada, p. 277

${ }^{96}$ EVANS, Peter, A tríplice aliança. Rio de Janeiro: Zahar, 1980, p. 33.

${ }^{97}$ FURTADO, Celso, Desenvolvimento e Subdesenvolvimento. Rio de Janeiro: Fundo de cultura, 1963, p. 182.
} 
O debate torna-se mais interessante quando consideramos as especificidades da condição periférica brasileira. Como dito acima, para receber o capital estrangeiro faziase necessário algum grau de desenvolvimento das forças produtivas por parte das economias receptoras desses recursos; sabemos que estes desembarcavam sob forma monetária, como capacidade produtiva ou ainda como mercadorias. Ainda que a abertura ao capital estrangeiro tenha reforçado laços de dependência, a partir da sua entrada após a década de 1860 o Brasil assistiu à diversificação e à modernização da sua infraestrutura via instalação de maquinaria, além de alguma unificação de seu mercado de trabalho e consumidor. Consideraremos que a mesma infraestrutura que serviu para o crescimento da produção para o mercado mundial também possibilitou, a longo prazo, a formação de uma demanda interna, cujo desenrolar ao longo do século XX permitirá as primeiras experiências de substituição de importações.

Como dito acima, entre 1889 e 1914, as profundas mudanças sofridas pelo capitalismo em escala global afetaram a economia brasileira de maneira significativa. Apesar de verificarmos razoável entrada de companhias de seguros estrangeiras no período em questão, constatamos que o setor nacional foi maior e mais bem-sucedido que o externo, como apresentaremos com dados empíricos mais à frente. Temos, portanto, que o período significou não apenas um momento de expansão econômica para os países do centro como também uma fase de desenvolvimento doméstico do capitalismo nacional.

Cabe chamarmos atenção para o fato de que a emergência de um setor de seguros nacional, que começa a florescer a partir da década de 1860 e se consolida na de 1890, fez-se em um contexto de intensificação dos fluxos de mercadorias e capitais em nível global, situação que acaba por trazer uma onda de investimentos estrangeiros ao Brasil. Mesmo assim, o setor se desenvolve e o número de firmas brasileiras ultrapassa as seguradoras estrangeiras. Ambas possuem em comum, no entanto, o fato de funcionarem sob novas condições, a saber, em um contexto de ampliação dos laços financeiros no âmbito da economia mundial e também doméstica. $\mathrm{O}$ exemplo das companhias de seguros, cuja atuação a partir da década de 1880 deixa de ser apenas mercantil e cada vez mais se constitui como financeira, também será comprovada empiricamente nos capítulos a seguir. 


\subsection{Ampliação dos circuitos financeiros e instabilidade cambial}

O estreitamento das relações financeiras com os mercados estrangeiros a partir da década de 1870 levou ao aumento crescente da participação da conta de capitais no âmbito do balanço de pagamentos brasileiro. Com contínuas entradas e remessas monetárias, as crises cambiais passaram a ser cada vez mais comuns, advindas tanto da instabilidade da oferta de financiamento do exterior quanto dos próprios mecanismos de transferência de valor das companhias estrangeiras, que repatriavam seus lucros, rendas e royalties, além dos juros cobrados sobre os títulos da dívida pública. A condição de vulnerabilidade cambial pode ser bem ilustrada pela dificuldade brasileira em adentrar efetivamente no sistema do padrão-ouro internacional, fazendo-o somente após a criação da Caixa de Conversão, em 1906, quando a disponibilidade de recursos estrangeiros permitiu a valorização do câmbio e o controle da inflação. ${ }^{98}$

A discussão a respeito da instabilidade cambial brasileira foi tema bastante debatido pela literatura econômica. A obra clássica de Celso Furtado apresentou a dependência da exportação de produtos agrícolas como causa das agudas oscilações das reservas metálicas; em momentos de crise nos centros industriais, o consumo de bens primários, bem como seus preços, diminuía. Economias dependentes como a brasileira assistiam então a uma expressiva redução da entrada de divisas, resultando em desequilíbrios na balança de pagamentos. ${ }^{99}$ Nesses momentos era necessário utilizar as reservas metálicas nacionais para pagar as importações, situação que impedia o funcionamento do padrão ouro e levava a conta de capitais a se comportar de maneira adversa nas etapas de depressão comercial. ${ }^{100}$ Segundo Celso Furtado, os políticos brasileiros da segunda metade do século XIX possuíam dificuldades em propor outras saídas às crises financeiras fora dos esquemas do padrão ouro, imposto sobretudo pelos modelos europeus; a inconversibilidade era vista como uma patologia que necessitava ser sanada. ${ }^{101}$

Outro ponto de vista apresenta a conta de capitais como mecanismo capaz de compensar a instabilidade da receita comercial. Segundo Gustavo Franco, a entrada de

\footnotetext{
${ }^{98}$ FRITSCH, Winston. “Apogeu e crise na Primeira República: 1900-1930”. Marcelo de Paiva Abreu (org.). A ordem do progresso. Dois séculos de política econômica no Brasil. Rio de Janeiro: Editora Campus, 1995; FRANCO, Gustavo. "A primeira década republicana". Marcelo de Paiva Abreu (org.), obra citada; FURTADO, Celso. Formação Econômica do Brasil. Rio de Janeiro: Editora Fundo de Cultura, 1959.

${ }^{99}$ Ibidem, p. 186.

${ }^{100}$ Ibidem, p. 186

${ }^{101}$ FURTADO, Celso. Formação Econômica do Brasil. Rio de Janeiro: Editora Fundo de Cultura, 1959. p. 190.
} 
capitais externos no Brasil do final do século XIX e início do XX permitiu maiores níveis de absorção e melhores taxas de investimento, características com as quais o país não contaria se o investimento estrangeiro direto não tivesse crescido e se tornado expressivo. Sob esta perspectiva não haveria, portanto, a chamada "articulação perversa" entre as contas comerciais e o movimento do capital. ${ }^{102}$

Para o autor, a transição republicana foi um período marcado por importantes influências sobre o câmbio não percebidas pelos seus contemporâneos. Para além das flutuações de preços dos produtos primários exportados, os movimentos de capital e outros itens invisíveis no balanço de pagamentos eram úteis para explicar o valor da moeda. Segundo Gustavo Franco, o papel do preço do café na formação da taxa de câmbio não deveria, portanto, ser superestimado; apesar de verificarmos uma média de superávits na balança comercial brasileira entre os anos de 1876 e 1897, a conta corrente mostrouse negativa. O saldo de serviços, fretes, seguros, rendas de capitais, além de empréstimos e amortizações explica essa situação. ${ }^{103}$ Abaixo temos uma estimativa para o Balanço de Pagamentos do Brasil entre os anos de 1876 e 1897 formulada por Gustavo Franco:

\section{TABELA 1}

Estimativa para o Balanço de Pagamentos do Brasil (1876-1897) (médias anuais em milhares de libras esterlinas)

\begin{tabular}{|l|l|l|l|l|l|}
\hline & $1876-90$ & $1881-85$ & $1886-89$ & $1890-94$ & $1895-97$ \\
\hline $\begin{array}{l}\text { Balança } \\
\text { comercial }\end{array}$ & 3.867 & 1.769 & 3.696 & 3.525 & 2.240 \\
\hline Exportações & 20.036 & 18.124 & 23.563 & 29.374 & 28.934 \\
\hline $\begin{array}{l}\text { Importações } \\
\text { Saldo de }\end{array}$ & 16.169 & 16.355 & 19.867 & 25.849 & 26.694 \\
\hline $\begin{array}{l}\text { Fretes erviços } \\
\text { Seguros }\end{array}$ & -2.691 & -2.731 & -2.575 & -2716 & -2.761 \\
\hline
\end{tabular}

\footnotetext{
${ }^{102}$ FRANCO, Gustavo, obra citada, p. 13.

${ }^{103}$ FRANCO, Gustavo, Reforma monetária e instabilidade durante a transição republicana. Rio de Janeiro: BNDES, 1893, p. 38.
} 


\begin{tabular}{|l|l|l|l|l|l|}
\hline $\begin{array}{l}\text { Rendas de } \\
\text { capitais }\end{array}$ & -1.275 & -1.351 & -2.106 & -2.445 & -2.525 \\
\hline $\begin{array}{l}\text { Outros } \\
\text { serviços }\end{array}$ & -211 & -294 & -583 & -2.102 & -2.388 \\
\hline $\begin{array}{l}\text { Transações } \\
\text { correntes }\end{array}$ & -310 & -2.607 & -1.568 & -3.738 & -5.434 \\
\hline $\begin{array}{l}\text { Movimentos } \\
\text { de capitais }\end{array}$ & 805 & 2.481 & 10.965 & 549 & 6.190 \\
\hline Empréstimos & 121 & 854 & 10.539 & 902 & 4.250 \\
\hline $\begin{array}{l}\text { Amortizações } \\
\text { Investimento }\end{array}$ & -632 & -669 & -4.984 & -455 & -465 \\
\hline direto & 1.315 & 2.666 & 5.410 & 102 & 2.405 \\
\hline Saldo geral & +495 & -126 & +9.297 & -3.189 & +756 \\
\hline
\end{tabular}

Fonnte: FRANCO, Gustavo, Reforma monetária e instabilidade durante a transição republicana. Rio de Janeiro: BNDES, 1983, p. 38.

Verificamos a partir dos dados da Tabela 1 que o período em questão (1876-1897) apresentou sucessivos superávits na balança comercial, característica esperada dado o boom da produção e exportação cafeeira à época e a boa aceitação do produto nos mercados estrangeiros. No que diz respeito ao saldo dos serviços, formado sobretudo por fretes, seguros e rendas de capitais, bem como pelas transações correntes, constatamos déficits. Apesar das amortizações de pagamentos e juros no exterior demonstrarem repetidos déficits para o Brasil, o saldo do movimento de capitais é positivo: segundo Gustavo Franco, o valor dos investimentos diretos superava as remessas financeiras para o exterior.

Encontramos perspectiva oposta na obra de Celso Furtado. Segundo o autor, a ampliação do estoque de capital estrangeiro no Brasil não pôde compensar a crescente necessidade de pagamentos financeiros. Por maior que tenha se tornado a entrada de capital estrangeiro a partir da primeira década republicana, ela foi sempre inferior ao 
serviço da dívida pública, isto é, o pagamento dos juros, as amortizações, comissões e descontos. ${ }^{104}$

Os dados a respeito da remessa de lucros, juros e comissões para o ano de 1907, época em que o investimento estrangeiro no Brasil passava por momento relativamente favorável, nos trazem uma ideia acerca da posição ocupada pelas companhias de seguros nesse contexto. As remessas da União para pagamento de juros e dividendos de títulos e ações, aluguéis, seguros de vida e fogo naquele ano totalizaram $£ 4.000 .000$; a título de comparação, os gastos com juros, amortização da dívida externa e garantias de investimentos foram de $£ 8.000 .000$; as remessas às sedes de companhias de estradas de ferro, bondes elétricos, gás, água e esgoto, £1.500.000; lucros de bancos e agências financeiras, $£ 1.000 .000$; lucros dos comerciantes estrangeiros, importadores $\mathrm{e}$ exportadores, $£ 1.000 .000$; e, por fim, passagens de viajantes e imigrantes, $£ 500.000$. $^{105}$

Era comum que as remessas para fora do país superassem o saldo positivo da balança comercial. Abaixo apresentamos os dados acerca do saldo comercial brasileiro entre os anos de 1901 e 1908:

${ }^{104}$ FURTADO, Celso, Formação Econômica do Brasil. Rio de Janeiro: Editora Fundo de Cultura, 1959, p. 189

${ }^{105}$ BRASIL, Correio Paulistano, Arquivo Público do Estado de São Paulo, 20 de junho de 1907, p. 02. 


\section{TABELA 2}

Saldo da balança comercial brasileira (1901-1908)

(valores em libras esterlinas)

\begin{tabular}{|l|l|}
\hline ANO & SALDO \\
\hline 1901 & 19.244 .723 \\
\hline 1902 & 13. XX8.038* \\
\hline 1903 & 12.675 .316 \\
\hline 1904 & 13.514 .713 \\
\hline 1905 & 14.813 .063 \\
\hline 1906 & 13.861 .248 \\
\hline 1907 & 13.634 .809 \\
\hline 1908 & 5.348 .452 \\
\hline
\end{tabular}

Fonte: BRASIL, Correio Paulistano, Arquivo Público do Estado de São Paulo 15 de dezembro de 1908, p. 04. *Número ilegível no documento original

A partir dos dados da Tabela 2 notamos uma diminuição significativa no saldo da balança comercial para o ano de 1908, cujo valor representava apenas $42 \%$ do segundo pior ano da série (1903). Inferimos que muito provavelmente a situação se deveu à crise norte americana de 1907, quando a perda de confiança e uma súbita corrida aos principais bancos dos EUA levaram a uma crise de liquidez que afetou a capacidade de consumo da população; o mercado consumidor norte americano estava dentre os principais importadores do café brasileiro, que a partir de então sofre com a queda da demanda e tem seu preço significativamente diminuído. ${ }^{106}$ As consequências sobre a balança comercial brasileira em 1908 fizeram-se visíveis.

No que diz respeito aos valores das remessas anuais para o exterior, temos os seguintes dados para o ano de 1907:

${ }^{106}$ BRASIL, Relatório do Ministério da Fazenda, 1909, Introdução, p. XIV. 
TABELA 3

Remessas anuais para fora do país (1907)

(valores em libras esterlinas)

\begin{tabular}{|l|l|}
\hline Sociedades anônimas estrangeiras & 2.858 .802 \\
\hline Serviço de empréstimos estaduais e municipais & 1.231 .940 \\
\hline Companhias estrangeiras de seguros & 200.000 \\
\hline Passageiros para o exterior e outras remessas & 600.000 \\
\hline Despesas com ouro do governo federal & 5.600 .090 \\
\hline Remessas particulares & 2.734 .030 \\
\hline Total & 13.224 .862 \\
\hline
\end{tabular}

Fonte: BRASIL, Correio Paulistano, Arquivo Público do Estado de São Paulo, 15 de dezembro de 1908, p. 04.

Considerando que durante o ano de 1908 os gastos com remessas para o exterior permanecessem o mesmo, ou ao menos próximos, aos de 1907, temos que para aquele ano o déficit em ouro seria de 7.876.410 libras esterlinas (isto é, um superávit comercial de $£ 5.348 .452$ subtraídos os gastos com remessas, de $£ 13.224 .862$ ). Nos termos utilizados pela imprensa para descrever a situação:

Como, porém, a vida economica e financeira do país não pode parar, as sociedades anonymas extrangeiras, as companhias de seguro, aos passageiros para o exterior e os particulares hão de ter necessidade de remeter cambiais, e como o saldo total de 5.348 .452 libras "não chegará" para a solução dos compromissos "oficiaes" conclue-se que (...) a collectividade terá de liquidar o exercício de 1908 com um déficit de ouro na importancia de 7.876 .410 libras esterlinas. ${ }^{107}$

O ritmo expressivo sob o qual as companhias de seguros, nacionais e estrangeiras, compravam os títulos da dívida pública nacional pode nos mostrar a importância do

${ }^{107}$ BRASIL, Correio Paulistano, Arquivo Público do Estado de São Paulo, 15 de dezembro de 1908, p. 04. 
referido serviço, bem como sua constituição em mecanismo capaz de simultaneamente promover o financiamento do Estado e a acumulação do capital privado. ${ }^{108}$ Talvez dentre os motivos pelos quais as seguradoras tornaram-se grande credoras do governo federal no Brasil esteja o fato de possuírem ampla capacidade para formação de poupança; em momentos de pouca ocorrência de sinistros, seus fundos de reservas tornavam-se maiores e disponíveis, o que estimulava sua inversão em compra de títulos ou em atividades produtivas.

A despeito do governo brasileiro à época não possuir boas condições de solvência, e apesar do país não ser dotado de mecanismos jurídicos eficientes e ter de conviver com insegurança no cumprimento de contratos, as apólices federais eram consideradas opções de investimento bastante seguras, e compunham os fundos de reservas da maior parte dos bancos (junto de outros títulos seguros, como as ações de companhias ferroviárias). Com o avanço da legislação reguladora das companhias de seguros, a compra dos títulos da dívida tornou-se uma obrigação para que as sociedades pudessem obter suas cartas patentes de funcionamento; a compra da dívida federal, no entanto, fez-se com muita frequência antes da promulgação dessa legislação, em 1895, e para além dela. Manter parte de suas reservas em apólices da dívida pública era algo atraente para as companhias de seguros devido à garantia e à segurança desses títulos.

Citamos como exemplo os dados da Companhia de Seguros Terrestres e Marítimos Lloyd Americano, sociedade britânica fundada em 1900, com sede no Rio de Janeiro e agências em todas as cidades marítimas brasileiras, cujo capital em 1905 era de Rs 1.000:000\$000, o valor em apólices federais de Rs 350.000\$000, os depósitos no Tesouro Federal de Rs 200:000\$000; os prêmios recebidos (até 30 de junho de 1903) eram de Rs 1.822:997\$370, e os sinistros pagos, Rs 738:224\$212. O lucro da companhia naquele ano foi de Rs 306:166\$935. ${ }^{109}$ A possibilidade de poupar via lucros advindos da concessão de seguros fez dessa companhia, como tantas outras, credora do Estado.

Também era esse o caso da Companhia de Seguros Sul América, sociedade brasileira fundada em 1896, e que em 1907 possuía 35\% do seu ativo advindo de apólices da dívida pública brasileira, num total de Rs 5.706:221\$392. Os valores investidos em imóveis totalizavam Rs 3.912:623\$031, e em outros títulos, Rs 1.190:000\$000. ${ }^{110}$ Em

\footnotetext{
108 BRASIL, Correio Paulistano, Arquivo Público do Estado de São Paulo, 12 de fevereiro de 1906, p.01; BRASIL, Actos do poder executivo, 1892, p. 720; BRASIL. Diário Oficial da União, 04 de abril de 1894, p. 1023 e p. 1024. Casos específicos a esse respeito serão apresentados mais à frente.

${ }^{109}$ BRASIL, Correio Paulistano, Arquivo do Estado de São Paulo, 12 de fevereiro de 1905, p. 06.

${ }^{110}$ BRASIL, Correio Paulistano, Arquivo do Estado de São Paulo, 9 de fevereiro de 1908, p. 05.
} 
maio de 1908 a participação das apólices da dívida pública no ativo da companhia havia diminuído para $30 \%$, mas o valor cresceu em termos absolutos, chegando a Rs $6.450: 321 \$ 932 .{ }^{111}$

Em fevereiro de 1893 a Companhia de Seguros Marítimos e Terrestres Indemnisadora possuía 120 apólices da dívida pública federal, com juros de 5\%, e outras 30 apólices dos mesmos títulos com juros de 4\%; dentre os papéis privados, era proprietária de 94 letras hipotecárias do Banco de Crédito Real de São Paulo. ${ }^{112}$

Outro exemplo de sociedade engajada na compra de títulos da dívida é o da seguradora alemã Albingia, original de Hamburgo, que em 1908 tinha 16\% do seu ativo vindo de rendas financeiras (dentre hipotecas, debêntures e os títulos da dívida). ${ }^{113} \mathrm{~A}$ sociedade era operada pela firma Herm. Stolz \& Cia, casa importadora fundada no Rio de Janeiro por um comerciante alemão, cujo trabalho fazia-se a partir da compra de artigos em Hamburgo e da remessa destes últimos para o Brasil (máquinas para indústria e para a lavoura; tecidos de algodão, papel, drogas químicas, cimento, materiais para construção, tais como madeira, aço e ferro; secos e molhados, cereais, comestíveis, etc). Conforme desenvolviam-se suas atividades, a firma deixava de apenas importar mercadorias e participava de instalações de maquinário para fábricas, minas, trens para estradas de ferro, ou até mesmo de um aeroplano. ${ }^{114}$

Na seção de despachos e embarques, a Herm. \& Stolz passou a ser agente de embarcações, como no caso da Norddeutscher Lloyd desde 1876, encarregando-se de desembarcar suas mercadorias. O envolvimento com o comércio marítimo serviu de estímulo para que a Herm. Stolz \& Cia se interessasse pelo setor de seguros, tornando-se agente de companhias europeias, sobretudo das cidades alemãs de Hamburgo e Bremen. ${ }^{115}$

Através da leitura dos balanços das companhias instaladas no Brasil encontramos o financiamento de dívidas de outros países, muitas vezes do próprio país sede da sociedade; é o caso da The Royal Insurance Company, original de Liverpool e em funcionamento no Brasil desde o ano de 1864. Em balanço publicado no Correio Paulistano referente a dezembro de 1907, a companhia faz referência a empréstimos sobre

\footnotetext{
${ }^{111}$ BRASIL, Correio Paulistano, Arquivo do Estado de São Paulo, 07 de maio de 1908, p. 04.

112 BRASIL, Diário Oficial da União, 19 de fevereiro de 1893, p. 846

113 BRASIL, Correio Paulistano, Arquivo do Estado de São Paulo, 30 de maio de 1908, p. 05.

${ }^{114}$ BRASIL, Impressões do Brazil no século XX. Lloyd's Greater Britain Publishing Company, Arquivo Municipal de Cubatão, 1913, p. 577.

115 BRASIL, Impressões do Brazil no século XX. Lloyd's Greater Britain Publishing Company, Arquivo Municipal de Cubatão, 1913, p. 577.
} 
apólices e ações, títulos do governo britânico, títulos municipais e estaduais brasileiros, e "títulos estrangeiros e coloniais." 116 Ao citar as obrigações e títulos de estradas de ferro e companhias de gás e docas que compõem o ativo da seguradora, novamente o balanço diferencia sociedades "inglesas, brasileiras e coloniais." Dentre os ativos restantes, chamam atenção as hipotecas sobre propriedades, prédios e terrenos e juros a receber. ${ }^{117}$

Em outros momentos as seguradoras poderiam ser credoras especiais do governo, emprestando dinheiro de maneira direta (e não via compra de títulos). Em fevereiro de 1892, o Ministério dos Negócios da Agricultura, Commercio e Obras Públicas destinou o valor de Rs 299:237\$537 à liquidação de suas dívidas; além de pessoas físicas, são citados como credores algumas empresas, dentre elas a Companhia de Seguros Fidelidade, das mais antigas em funcionamento no Brasil e credora do Ministério desde 1890. A dívida total era de Rs 8:517\$935 e fora destinada a prêmios de seguros marítimos e materiais importados utilizados pelo governo. ${ }^{118}$

É interessante chamarmos atenção para o fato de que a dependência de produtos agrícolas na sustentação do balanço de pagamentos e a subsequente vulnerabilidade cambial era algo notado pelas autoridades econômicas das primeiras décadas republicanas e, além disso, tomado como condição a ser superada. Os exemplos são abundantes, como notamos pela fala de Francisco Salles, ministro da Fazenda entre 1910 e 1913, no Relatório do Ministério da Fazenda de 1911:

Sobretudo é tempo de procurarmos obstinadamente outros productos para a grande exportação. (...) A produção daquele dois generos [café e borracha] apenas é um perigo permanente, é a instabilidade econômica, é a ameaça de abalos financeiros, dada uma crise de baixa do preço ou de falha na producção que, diminuindo a entrada de ouro estrangeiro, nos obrigue, para fazer face do custo da importação, lançar mão das nossas reservas metallicas, deprimindo a taxa de cambio. ${ }^{119}$

Ou mesmo Rivadavia da Cunha Correia, Ministro da Fazenda entre 1913 e 1914, que ao enfrentar um contexto marcado pela queda das exportações dos principais produtos brasileiros, considerava: “As afflictivas crises que, por vezes, tem pesado sobre o café e

\footnotetext{
${ }^{116}$ BRASIL, Correio Paulistano, Arquivo do Estado de São Paulo, 16 de agosto de 1908, p. 05.

117 Ibidem, p. 05

118 Ibidem, p. 42

${ }^{119}$ BRASIL, Relatório Ministério da Fazenda, 1910/1911, p.7
} 
sobre a borracha, não foram ainda bastantes para indicar aos nossos patrícios de não confiar somente nesses dous ricos productos de seu labor". ${ }^{120}$

\subsection{As companhias de seguros e as associações mútuas e de montepio}

A partir da década de 1890, constatamos o surgimento de uma série de instituições e associações mútuas preocupadas com a formação de poupanças familiares e individuais, com a concessão de auxílios, previdência e seguros de vida. Além de denotar maior atenção por parte das classes trabalhadoras com sua própria situação financeira e seu futuro, o movimento traduzia a preocupação do governo em estimular a formação de uma poupança nacional.

Como a maior parte dos países latino americanos, o Brasil de então tinha suas políticas macroeconômicas bastante dependentes dos ciclos dos produtos de exportação, cujos percalços variavam de acordo com a concorrência internacional, com as mudanças da demanda ou mesmo a partir do surgimento de produtos substitutos. ${ }^{121}$ Pode-se afirmar que a constatada instabilidade cambial brasileira influenciou as possibilidades de atuação financeira das companhias de seguros que aqui se instalaram, cuja constante formação de poupanças, inerente ao seu funcionamento, interessava ao governo, sobretudo nos momentos de escassez de reservas. Buscaremos tratar essa questão inserindo a discussão acerca das companhias de seguros no debate mais amplo a respeito do crédito.

Como exemplo de sociedade cuja atuação levava à contínua formação de poupança, citaremos o caso da Companhia Brazileira de Seguros para a Vida, que passa a funcionar em maio de 1889. A Companhia operava de maneira um tanto específica: após a venda das apólices de seguros de vida aos interessados, eram pagos aos segurados valores trimestrais que aumentariam gradualmente, na razão dos falecimentos dos segurados de cada grupo de fundos, até que os próprios fundos se extinguissem; tinha-se em funcionamento uma instituição financeira cujo fim principal era a manutenção da renda e a formação de poupança de terceiros. ${ }^{122}$

Segundo as expectativas apresentadas pelo seu estatuto, a Companhia duraria por 90 anos após sua data de inauguração e funcionaria na sua sede, Rio de Janeiro, podendo abrir agências em todo o território nacional sob condição de autorização do governo. Era

\footnotetext{
${ }^{120}$ BRASIL, Relatório Ministério da Fazenda, 1913 (I), p. vi.

${ }^{121}$ BÉRTOLA, Luis \& OCAMPO, José Antonio, O desenvolvimento econômico da América Latina desde a Independência. Rio de Janeiro: Elsevier, 2015, p. 106.

122 BRASIL, Actos do Poder Executivo, 1899, p. 731.
} 
proibido que realizasse operações estranhas aos seus fins principais e não poderia ressegurar seus contratos em companhias estrangeiras, sob pena de ter cassada sua autorização para funcionar. Seu capital era de Rs 400:000\$000, divididos em 2.000 ações de Rs $200 \$ 000$ cada. Da renda líquida eram retirados 10\%, no mínimo, para constituição de seu fundo de reserva, até que se atingisse o capital social de Rs 400:000\$000; no caso de seu capital social sofrer perdas, o fundo de reserva serviria para suprir o que fosse necessário para constituí-lo.

Os segurados poderiam obter duas categorias distintas de seguros: misto ou especial. A categoria de seguros mistos poderia ser concedida a segurados de qualquer idade, e os especiais seriam os grupos com idade determinada na ocasião de emissão da apólice. O valor nominal das apólices da categoria mista era de Rs 500:000\$000, enquanto o grupo especial pagava Rs 250:000\$000. Os capitais dos segurados formavam um fundo especial, denominado Patrimônio dos Segurados, que contava com administração específica. $^{123}$

A renda vitalícia a qual os segurados tinham acesso era, nos quatro primeiros trimestres de cada apólice, paga na razão de $10 \%$ ao ano, sempre calculados sobre o valor nominal da apólice. Após os quatro primeiros trimestres, porém, a renda era resultado de uma partilha proporcional do rendimento do patrimônio existente. Nas vezes que esse patrimônio não foi suficiente para pagamento da renda vitalícia dentre todos os segurados, os fundos sociais da Companhia foram utilizados para suprir o que fosse necessário. A Companhia não poderia emitir novas apólices sem que a administração do patrimônio estivesse em posse de $75 \%$ de seu valor respectivo. ${ }^{124}$

Os capitais sociais e do fundo de reserva que excediam às necessidades de custeio poderiam ser empregados em outros investimentos, como empréstimos de imóveis urbanos ou suburbanos, sempre mediante hipotecas; adiantamento de juros da dívida pública da União; empréstimos mediante depósitos de ouro, prata ou pedras preciosas, não sendo cada operação de valor inferior a um conto de réis; compra de imóveis urbanos ou suburbanos. Segundo seu estatuto: "Além dessas operações, a administração poderá adoptar outras que offereçam segurança e boa renda." ${ }^{125}$

Outro exemplo de seguradora preocupada com a formação de poupanças era a Associação de Seguros sobre Vida, Contrafogo e de Crédito e Montepio Comercial -

\footnotetext{
${ }^{123}$ BRASIL, Actos do Poder Executivo, 1899, p 733

${ }^{124}$ BRASIL, Actos do Poder Executivo, 1899, p.735

125 BRASIL, Actos do Poder Executivo, 1899, p. 737
} 
Brazil, formada no Rio de Janeiro em janeiro de 1893. Novamente dispomos apenas dos dados de seu estatuto, publicado nos Atos do Poder Executivo de 1899; a partir das expectativas da documentação, sabemos que a companhia se propunha a conceder seguros de vida e de fogo, bem como "facilitar a todas as pessoas, ainda as menos abastadas, a accumulação de suas economias pela criação de capitaes, pensões, heranças, rendas, etc., por meio de contribuições feitas, quer por uma só vez, quer annualmente ou por semestre e trimestres." 126

A Associação dividia suas operações entre seguros de vida, seguros de fogo e seguros de crédito e montepio comercial, e era autorizada a funcionar após a subscrição total de ao menos Rs 800:000\$000. Os rendimentos que entrassem na Associação via concessão de seguros de vida eram imediatamente usados para compra de apólices da dívida pública, bem como outros títulos de crédito garantidos pelo governo federal ou pelos Estados. Esse mesmo montante poderia ficar em conta corrente a juros nos estabelecimentos de crédito "de confiança da direção geral", sobretudo no caso de os títulos do governo não representarem rendimento suficiente. ${ }^{127}$

Já o dinheiro que entrasse através dos seguros contrafogo seria remetido aos mesmos estabelecimentos de crédito escolhidos pela direção e não teria outra aplicação além de um fundo de Rs 200:000\$000 para pagamento de sinistros. O mesmo ocorria com os valores advindos via concessão de seguros de crédito e montepio comercial; aplicados em conta corrente, seus juros serviriam apenas para o pagamento das pensões do segurado, isto é, optava-se por manter o dinheiro parado em conta corrente ao invés de usá-lo para financiar o governo ou outras companhias privadas via compra de títulos.

As operações de seguro de crédito e montepio comercial eram consideradas benevolentes pela Associação, que pagava regularmente um valor, denominado pensão ou passivo, aos segurados que estivessem sob ameaça de insolvência ou risco de falência. O estatuto da companhia previa "agenciar o maior número possível de subscriptores, concorrendo assim para o maior desenvolvimento do philanthropico e humanitário grupo de seguro de crédito e montepio comercial." ${ }^{128}$ Instituições de crédito e de seguros preocupadas em atingir camadas da população pouquíssimo familiarizadas com a ideia de rendimentos financeiros eram fundamentais para a construção de um mercado de

\footnotetext{
${ }^{126}$ BRASIL, Actos do Poder Executivo, 1899, p. 555.

${ }^{127}$ BRASIL, Actos do Poder Executivo, 1899, p. 556.

${ }^{128}$ BRASIL, Actos do Poder Executivo, 1899, p. 561.
} 
capitais no Brasil, que não poderia desenvolver-se sem a existência de uma poupança nacional.

Os segurados dessas associações, no entanto, deveriam se submeter a regras rígidas para resgatar suas pensões. Para o recebimento dos valores a título de alimento por insolvência ou falência, o credor deveria penhorar todos seus bens e conferir à Associação poderes especiais sobre o valor do que fosse penhorado, como por exemplo a permissão de liquidá-los. O Conselho Fiscal da Associação era preocupado em evitar fraudes e enganos; se fosse comprovado o caso de o devedor associado ser insolvente desde antes de sua entrada no Montepio Comercial, ele perderia quaisquer direitos de indenização, além de ser proibido de fazer parte da sociedade e de recolher o prêmio a ela dado.

Era normal que membros de associações de classe se organizassem para a formação de um patrimônio comum e para concessão de seguros de vida. A Associação dos Empregados no Comércio do Rio de Janeiro, instituição igualmente organizada como beneficente instrutiva, foi fundada por um pequeno número de caixeiros em 1880 e em 1909 já ocupava um suntuoso palacete na Avenida Rio Branco. Os associados contavam com serviços de saúde, medicamentos, pensões a famílias, pensões por invalidez, auxílios a viagens, e uma seção de seguros de vida, organizada sob a base da mutualidade. ${ }^{129}$

Em 1903 foi fundada em São Paulo a Caixa Mútua de Pensões Vitalícias, associação de previdência formada por imigrantes italianos. Em 1905 foi aberta uma filial no Rio de Janeiro e aos poucos as agências se espalharam pelo Brasil, com casas do Amazonas ao Rio Grande do Sul; a nacionalidade italiana deixou de ser um pré-requisito e em 1911 a sociedade possuía um fundo de Rs 2.451:824\$207 dividido entre hipotecas, depósitos em bancos e apólices da dívida federal. ${ }^{130}$

Em 1909 foi criada a Sociedade de Auxílios Mútuos, ou Montepio da Família, cujo objetivo era a concessão de seguros de vida por mutualidade via pagamento aos herdeiros do sócio falecido. As condições de admissão na sociedade incluíam a submissão a exame médico, ter de 21 a 55 anos de idade; pagar a joia de Rs 1:000\$000, de uma só vez ou por prestações, e mais Rs $15 \$ 000$ cada vez que falecesse um associado dentro do

\footnotetext{
${ }^{129}$ BRASIL, Impressões do Brazil no século XX. Lloyd's Greater Britain Publishing Company, Arquivo Municipal de Cubatão, 1913, p. 521.

${ }^{130}$ Ibidem, p. 666.
} 
prazo de 20 dias. Até o ano de 1913, cerca de Rs 450:000\$000 haviam sido pagos em pecúlios aos associados. ${ }^{131}$

Por fim, citaremos o caso da União Mútua, Companhia Construtora e de Crédito Popular, proprietária de agências no Rio de Janeiro, São Paulo, Santos e Belo Horizonte. A companhia concedia os chamados "pecúlios de vida", além de adiantar os capitais necessários para compra ou construção de moradias, a serem restituídos em pequenas prestações mensais. Até janeiro de 1912, a União Mútua havia pago cerca de Rs 557:500\$000 em pecúlios; seu capital mutuário subscrito era de Rs 25:000\$000 e o capital acionista de Rs. 1.000:000\$000. ${ }^{132}$

Conforme desenvolviam-se as sociedades de montepios e pecúlios, novos sistemas de administração de poupança surgiam. Já em 1897 foi instituída a Companhia de Seguros de Vida Auxiliadora, com sede e foro jurídico no Rio de Janeiro. Efetuava seguros sobre a vida "por todos os planos e combinações já existentes e pelo novo sistema -seguro tontina em conta de participação(...)" ${ }^{133} \mathrm{O}$ sistema em questão é descrito pelo próprio estatuto como tendo por finalidade fomentar a previdência em todas as classes sociais "por meios fáceis e ao alcance de todos"; em pequenas prestações, em um tempo mais ou menos longo, seria possível aos segurados constituir o direito ou posse de um capital, a ser resgatado, por exemplo, por herdeiros e sucessores legais.

Nas palavras do memorial da companhia que descreve tal sistema: "A estructura deste novo systema de seguros sobre a vida - systema verdadeiramente popular - e o meio prático e fácil de contribuir e retribuir, são a própria garantia e probabilidade de bom êxito $(\ldots)^{\prime \prime 134}$

Os segurados nesse sistema seriam considerados contribuintes e/ou remidos. Os contribuintes eram aqueles que, como prêmio do seguro, efetuavam contribuição mínima de 30\$000 mensais, recebendo em troca cupons representativos da contribuição. Remidos seriam os possuidores de 10.000 desses cupons; era através da posse destes últimos, bem como da apólice dos seguros, que poderia se provar os anos de contribuição e, portanto, o resgate de indenizações. ${ }^{135}$

\footnotetext{
${ }^{131}$ BRASIL, Impressões do Brazil no século XX. Lloyd's Greater Britain Publishing Company, Arquivo Municipal de Cubatão, 1913, p. 699.

${ }^{132}$ BRASIL, Impressões do Brazil no século XX. Lloyd's Greater Britain Publishing Company, Arquivo Municipal de Cubatão, 1913, p. 699.

${ }^{133}$ Ibidem, p. 699 (destaques meus)

${ }^{134}$ BRASIL, Actos do Poder Executivo, 1897, p.264.

135 BRASIL, Actos do Poder Executivo, 1897, p.264.
} 
Já no século XX, constatamos o mesmo estímulo à formação de poupança pessoal via companhias de seguros e associações de montepio, por vezes referidas na imprensa como "economias forçadas." ${ }^{36}$ Apólices de seguros estavam dentre os bens transmitidos, herdados e encontrados em cofres, como no caso da loja de confecções paulistana Casa Alemã, cujos cofres após incêndio em 1909 contavam com letras da câmara de Santos, debêntures de firmas, títulos ao portador, joias e muitas apólices de seguros. ${ }^{137}$ Em 1910, o Relatório do Ministério da Fazenda refere-se ao funcionamento do Instituto de Montepio Civil Nacional, e expressa as expectativas do Ministério da Fazenda em tornálo uma instituição cada vez mais autônoma e menos dependente das receitas do Tesouro, isto é, se autofinanciando a partir dos recursos dos próprios mutuários. Segundo o Relatório:

Seria conveniente uma reorganização do instituto do montepio civil que o habilitasse a ter vida própria ou dependente apenas de pequeno auxilio, aliás justificável, dos cofres publicos. A vingar esta idéa, o critério a adoptar-se seria o de estabelecer novas condições de admissão. ${ }^{138}$

Em 1906 surgiram as primeiras discussões para regulamentar a pensão de funcionários do Estado, a saber, os magistrados do Poder Judiciário. Na Constituição de 1891 verificamos a existência do assunto no art. 87: “a lei garante montepio aos magistrados segundo as leis que forem estabelecidas em regulamento pelo governo, approvado pelo Congresso."139 Desde 1891, no entanto, a lei não havia ainda sido regulamentada pelos deputados, segundo o relator da legislação, "por um receio, talvez exaggerado, mas sempre louvável, de pesar sobre os cofres do Estado." ${ }^{140}$ Para o referido deputado a criação de um montepio para o Poder Judiciário era urgente:

Devemos, pois, fazel-o sem demora, tanto mais quando se descobre uma formula feliz que, satisfazendo à bemfazeja aspiração, não acarreta o mínimo encargo nem responsabilidade certa ou incerta, actual ou futura, prevista ou eventual, para os cofres do Thesouro Publico. ${ }^{141}$

E completava:

\footnotetext{
${ }^{136}$ BRASIL, Correio Paulistano, Arquivo Público do Estado de São Paulo, 21 de agosto de 1906.

${ }^{137}$ BRASIL, Correio Paulistano, Arquivo Público do Estado de São Paulo, 01 de dezembro de 1909, p. 04.

${ }^{138}$ BRASIL, Relatório do Ministério da Fazenda, 1910/11, p. 150.

${ }^{139}$ BRASIL, Correio Paulistano, Arquivo Público do Estado de São Paulo, 24 de julho de 1906, p. 04.

140 Ibidem, p. 04.

${ }^{141}$ Ibidem, p. 04
} 
Sabemos que no mundo inteiro se tem cogitado da garantia de um patrimonio para as familias dos servidores publicos; e difícil, sinão impossível, tem sido conciliar os interesses, garantindo esse patrimonio, sem arruinar o erário publico. ${ }^{142}$

Segundo o deputado Marques de Azevedo, todas as tentativas anteriores para formação de poupança de funcionários, públicos ou não, haviam dado errado. Logo no início da República, Rui Barbosa propôs o montepio obrigatório, no qual cada funcionário contribuiria mensalmente com o equivalente a um dia de seu ordenado, de modo que sua família pudesse contar mensalmente com metade do valor. O projeto foi posto em prática, mas não se mostrou sustentável e não durou, obrigando o governo republicano a extinguir as pensões; "a perpetuidade das pensões, cujo limite não se pode medir, é, pois, impraticável". afirmou o primeiro Ministro da Fazenda republicano. ${ }^{143}$

O projeto apresentado por Marques de Azevedo propunha que o regime de pensão vitalícia fosse substituído pela entrega de um "pecúlio considerável”, de uma só vez; ao contrário de Rui Barbosa, Marques de Azevedo não propunha um sistema de pensões para todos os funcionários, pois sua preocupação era apenas com os magistrados. Segundo ele, o projeto era um "mixto de seguro de vida cooperativamente organizado. "144 Nas suas palavras:

E, si o meu projeto não se refere à classe inteira dos funcionários publicos, é porque faltou tempo ao estudo do problema geral, que é um dos mais complexos e dificeis. ${ }^{145}$

Em 1909, novamente discutiu-se a formação de outra associação de proteção aos funcionários públicos; a Comissão de Fazendas e Contas do Senado analisou projeto para criação da Caixa Beneficente dos Empregados Públicos do Estado de São Paulo, cujo fim principal era socorrer o funcionário público que, a partir de quatro anos de serviço, fosse obrigado a deixar o cargo por invalidez física e sem direito à aposentadoria. A esse indivíduo seria concedido o usufruto de uma poupança em apólices da dívida pública do Estado, a depender do tempo de contribuição e salário; o valor, no entanto, não poderia nunca ser nem superior a Rs 30:000\$000 nem inferior a Rs 5:000\$000. A receita da Caixa Beneficente seria composta por um dia de trabalho dos funcionários, não tendo o Estado

\footnotetext{
${ }^{142}$ BRASIL, Correio Paulistano, Arquivo Público do Estado de São Paulo, 24 de julho de 1906, p. 04

${ }^{143}$ Ibidem, p. 04

${ }^{144}$ Ibidem, p. 04

${ }^{145}$ Ibidem, p. 04
} 
nenhuma responsabilidade pelo pagamento dos valores, ficando a seu cargo unicamente a arrecadação, administração e entrega do patrimônio da Caixa. ${ }^{146}$

A associação definia a si mesma como uma sociedade de seguros mútuos onde os segurados eram os próprios seguradores. Em defesa do projeto no Congresso Legislativo do Estado de São Paulo, foi dito que a Caixa Beneficente, ao contrário das companhias de seguro, não necessitaria de despesas com administração para funcionar e não tinha como objetivo o lucro ou o pagamento de dividendos, daí sua possibilidade de cobrar prestações mais baixas de seus interessados. A ideia era que os mutuários pudessem formar poupanças significativas se aplicassem o dinheiro em títulos do governo, pois, segundo o deputado autor do projeto da Caixa Beneficente, referindo-se às altas taxas de juros brasileiras, “é certo que o capital entre nós obtém maior renda do que na Europa, mesmo em títulos públicos da maior segurança."147

O projeto de lei citava ainda a ampla disponibilidade de capital que a Caixa Beneficente, ao final aprovada, possuía em comparação às companhias de seguros, cujos recursos disponíveis para fazer frente a possíveis sinistros eram sempre no máximo 30\% das receitas totais; no caso da Caixa Beneficente, no lugar de apenas 30\%, um total de $40 \%$ ia para a poupança de acidentes futuros, e outros $30 \%$ para despesas de administração e lucros de capital. ${ }^{148}$

Não cabe aqui entrarmos em detalhes a respeito do projeto de pensões para a classe dos magistrados; apresentamos a discussão apenas com o intuito de chamar atenção ao anseio dos políticos republicanos para com a formação de poupanças no "paiz novo e pobre", nas palavras do Correio Paulistano. ${ }^{149}$ Através dos exemplos apresentados, notamos uma onda bastante expressiva de instituições de seguros, crédito e previdência sendo formadas no final do século XIX brasileiro, em consonância com as mudanças pelas quais o capitalismo passava no período em questão. A maior importância dos circuitos financeiros nacionais e estrangeiros também tem seu reflexo na formação de poupanças, cada vez mais expressivas, fossem elas familiares, públicas ou de grandes sociedades e companhias. O setor de seguros, cujo funcionamento possui estreita ligação com a formação de grandes poupanças, conhece nesse período um aprofundamento de suas funções financeiras, para além das mercantis.

\footnotetext{
${ }^{146}$ BRASIL, Correio Paulistano, Arquivo Público do Estado de São Paulo, 15 de dezembro de 1909, p. 02 ${ }^{147}$ BRASIL, Correio Paulistano, Arquivo Público do Estado de São Paulo, 15 de dezembro de 1909, p. 02 148 Ibidem, p. 02

${ }^{149}$ Ibidem, p. 02
} 


\subsection{Crédito e expansão financeira}

A referida vulnerabilidade cambial da economia brasileira influenciará de maneira direta as condições de atuação, tanto mercantil quanto financeira, das companhias de seguros. Sabemos que entre 1889 e 1914 a atuação destas empresas conheceu uma expansão financeira bastante significativa; para além das apólices concedidas às plantações, embarcações, fretes e contrafogo, as sociedades seguradoras passam também a oferecer crédito privado e a comprar títulos privados e públicos, sobretudo os títulos da dívida pública do governo brasileiro. As implicações na economia nacional são diretas: como dito acima, aos poucos assiste-se à formação de uma pequena poupança, nacional e privada, cujos recursos serão utilizados no financiamento da máquina pública e de empreendimentos particulares.

Conforme se complexificam as relações capitalistas de uma economia pouco monetizada como a brasileira do final do século XIX e início do XX, as companhias de seguro se inserem como instituições financeiras e passam a vender serviços antes inexistentes, e muito pouco relevantes, no contexto brasileiro. Como exemplo, citamos a Companhia Sul América, que em agosto de 1905 anuncia no Correio Paulistano uma "apólice de acumulação" para seguros de vida. Após pagarem o prêmio correspondente e adquirirem a apólice, os segurados poderiam tomar empréstimos a partir do segundo ano de vigência do contrato de seguro e sob juros de $5 \%$ ano. ${ }^{150}$ Considerando que os bancos paulistas na década de 1910 cobravam entre 8 e 12\% pelos empréstimos concedidos, temos que a taxa proposta pela Sul América era bastante atraente. ${ }^{151}$ Os recursos "ociosos" não utilizados pela seguradora tornavam-se base de empréstimos e permitiam sua inserção financeira como credora. Segundo anúncio da Sul América no referido jornal:

Nestas condições, com tão extraordinárias vantagens, qual o chefe de família que se negará a instituir um seguro de vida na Sul América para garantir a seus filhos

\footnotetext{
${ }^{150}$ BRASIL, Correio Paulistano, Arquivo Público do Estado de São Paulo, 09 de agosto de 1905, p. 04. ${ }^{151}$ As taxas de desconto praticadas pelos bancos paulistas do interior eram mais altas que na capital. Para a capital paulista em 1914, vemos serem praticadas taxas de juros de $11 \%$ ao ano, em um empréstimo concedido pelo British Bank of South America à Sociedade Incorporadora, instituição que organizava o crédito cooperativo em São Paulo. CORREA, Fábio Rogério Cassimiro, Os Bancos de Custeio Rural e o crédito agrícola em São Paulo (1906-1914). 2014. 199 f. Dissertação (Mestrado em História). Faculdade de Filosofia, Letras e Ciências Humanas, Universidade de São Paulo, São Paulo, 2014.
} 
ou à esposa uma herança certa e líquida, em dinheiro à vista, dado o caso de seu fallecimento prematuro, e que ao mesmo tempo será um capital que elle mesmo poderá liquidar em vida, para seu proprio gosto? ${ }^{152}$

Considerando as precárias características do mercado de capitais brasileiro à época, marcado pelo pequeno número de bancos comerciais, elevados índices de concentração bancária e acesso ao crédito permeado por personalismo e certa arbitrariedade, tem-se que o custo do capital era bastante alto. Obter empréstimos invariavelmente envolvia o pagamento de elevadas taxas de juros; essa parece ter sido a condição de um mercado financeiro formado tardiamente. Podemos apontar como elemento encarecedor das taxas de juros a dificuldade de os tomadores de empréstimos apresentarem garantias; desde a década de 1880, a propriedade agrícola escravista, sobretudo a fluminense, se desvalorizava na eminência da abolição da escravidão e com a expectativa das profundas transformações a serem sofridas pela força de trabalho nacional. Em 1884, quatro anos antes da abolição, o Banco do Brasil deixara de aceitar escravos como garantia para empréstimos. ${ }^{153}$ Os insucessos nas tentativas de implementação do crédito hipotecário no Brasil, tema a ser tratado mais à frente, também demonstram as dificuldades de mobilizar a renda e o patrimônio como garantidores de empréstimos.

A ideia da valorização financeira via acumulação de juros aos poucos passava a fazer parte do cotidiano dos poucos brasileiros que mantinham dinheiro nos bancos, compravam debêntures, títulos da dívida pública, ou possuíam apólices de companhias de seguros. Em 1907, apesar do país já ter superado a crise do Encilhamento, causava espanto e era motivo de muita cobiça o fato da seguradora nacional Equitativa ter pago cerca de Rs 30:000\$000 a um segurado cujo pagamento do prêmio havia sido de apenas Rs $1: 751 \$ 400 .{ }^{154}$

O aprofundamento das relações financeiras no Brasil, cujo desenrolar ultrapassou o âmbito privado e atingiu a estrutura do Estado, levanta interessantes questões teóricas a respeito do crédito como instrumento utilizado na esfera pública e privada. Buscaremos

\footnotetext{
152 BRASIL, Correio Paulistano, Arquivo Público do Estado de São Paulo, 09 de agosto de 1905, p. 04. (grifos originais).

153 SCHULZ, John, obra citada, p. 16

${ }^{154}$ BRASIL, Correio Paulistano, Arquivo Público do Estado de São Paulo, 05 de junho de 1907, p. 05.
} 
desenvolver esta questão a partir das proposições a esse respeito apresentadas por Rudolf Hilferding em $O$ Capital Financeiro ${ }^{155}$.

Em sua análise a respeito do crédito e do dinheiro, afirma o autor ser necessária a diferenciação deste último como meio de circulação e como meio de pagamento. Sob a primeira classificação, o dinheiro se apresenta como simples intermediário da circulação de bens, como forma pela qual o valor da mercadoria se expressa de maneira socialmente válida; na impossibilidade de servirem como expressão direta de seu próprio valor de troca, as mercadorias devem ser permutadas a partir de um equivalente universal que seja também, ele próprio, um valor passível de compra e venda. ${ }^{156}$

Como meio de pagamento, porém, a forma dinheiro enseja uma relação econômica mais complexa. Tal denominação refere-se às transações em que a venda da mercadoria e seu respectivo pagamento não coincidem temporalmente, isto é, quando a mercadoria é vendida porém paga mais adiante. A relação social intrínseca ao contato entre vendedor e comprador se estabelece, portanto, antes que o dinheiro apareça e exerça sua função; a consumação do ciclo da mercadoria, nesse caso, não é completada. ${ }^{157}$ Ela é entregue em troca de uma letra de câmbio ou de uma nota promissória, e cria-se uma dívida privada entre os sujeitos da troca. ${ }^{158}$

Tem-se aqui importante momento na teoria do dinheiro de Hilferding, de especial interesse para esta pesquisa, pois o autor faz a definição do que considera ser moeda fiduciária. Diferentemente de outras definições que a denominam como papel-moeda estatal de curso forçado, segundo Hilferding a moeda fiduciária define-se justamente por ser a que pagará a dívida particular estabelecida entre o vendedor e o comprador que realizarem sua troca através do dinheiro como meio de pagamento. Ela é garantida de forma privada, a partir de uma relação especifica entre os contraentes, ao contrário do

155 HILFERDING, Rudolf, O Capital Financeiro. São Paulo: Nova Cultural. Coleção Os Economistas. 1985. Nota-se que a análise do curso do dinheiro, bem como da sua função como meio de pagamento, foi anteriormente realizada por Marx no Livro I do Capital. MARX, O Capital. São Paulo: Abril Cultural, 1983. Volume I, tomo I, capítulo III, p. 114.

${ }^{156}$ HILFERDING, Rudolf, O Capital Financeiro. São Paulo: Nova Cultural. Coleção Os Economistas. 1985 , p. 44.

${ }^{157}$ Ibidem, p. 65.

${ }^{158}$ Cabe aqui chamar atenção para o fato de que, para Marx, não deve haver dicotomia entre circulação e capital; o dinheiro pode circular tanto na sua forma rendimento (meio de circulação) quanto na sua forma capital (meio de pagamento). MARX, Karl, obra citada, vol. III, t. I, cap. XXVIII, p. 337. 
papel-moeda estatal de curso forçado, que é emitido pelo Estado e garantido socialmente. ${ }^{159}$

Para além das implicações da definição específica de moeda fiduciária feita por Hilferding, tal formulação é pertinente por apresentar os mecanismos pelos quais as relações capitalistas se complexificam conforme se desenrolam; a emergência do dinheiro como meio de pagamento e não mais como simples meio de circulação, a perda de simultaneidade do momento da obtenção e o momento de pagamento da mercadoria, a concessão de letras de câmbio que funcionam como moeda fiduciária e adiam a entrada da riqueza real no ciclo de trocas, todos esses aspectos parecem denotar o modo como as condições de circulação tornam-se mais complexas ao longo da evolução do capitalismo.

Partindo do pressuposto de que a maior parte das relações de compra e venda na economia brasileira do período em questão se estabelece através do dinheiro como meio de pagamento e que não mais se faz obrigatória a relação imediata entre os atos de compra e pagamento das mercadorias, o crédito de fato apresenta-se como tema digno de análise para que se compreenda a história econômica brasileira do período. ${ }^{160}$

Para que se continue a apresentá-lo a partir dos seus pressupostos teóricos, devese atentar à diferenciação do crédito como empréstimo a juros fornecido pelo proprietário do dinheiro (crédito de capital) e como crédito simples advindo da transformação do dinheiro de meio de circulação para meio de pagamento (crédito de circulação). Segundo

\footnotetext{
${ }^{159}$ MARX, obra citada, vol. III, t. I, cap. XXVIII, p. 67. "O papel moeda estatal não se fundamenta, em contrapartida, em nenhuma relação de crédito, sendo de todo errôneo qualifica-lo de dívida do Estado ou de moeda fiduciária."

${ }^{160} \mathrm{O}$ tema do crédito, cuja importância para a produção capitalista é apresentada por Marx no Livro III do $O$ Capital (t. I, cap. XXVII, p. 331), foi bastante tratado na historiografia econômica. A conhecida controvérsia do colapso envolvendo os membros da social democracia alemã do final do século XIX e início do XX dividiu opiniões a respeito do sistema de crédito e da função dos cartéis. Autores como R. Hilferding e E. Bernstein afirmaram que as crises econômicas seriam atenuadas pela concentração industrial e pelo domínio dos bancos sobre as fábricas; em oposição, R. Luxemburgo tratou os fatores da suposta atenuação das crises como aceleradores das contradições inerentes ao capital. A questão já havia sido tratada por Marx na sua apresentação da condição dialética do crédito, ele próprio uma estrutura econômica contraditória que, ao mesmo tempo em que estimula (Aufhebung) e protege o movimento do capital, também o destrói, pois acirra as crises de superprodução e acelera a passagem da apropriação privada dos meios de produção para as sociedades por ações, constitutivas da fase final do capitalismo. MARX, obra citada, Livro III, t. II, c. XXX, p. 22.

Cita-se como exemplo de obras que trataram do crédito no âmbito da economia brasileira: Flávio Azevedo Saes, Crédito e bancos no desenvolvimento da economia paulista (1850-1950). São Paulo: Instituto de Pesquisas Econômicas, 1986; Gail Triner, Banking and economic development: Brazil, 1889-1930. New York: Palgrave, 2000; Anne Hanley, Native Capital: financial institutions and economic development in São Paulo, Brazil, 1850-1920. Stanford: Stanford University Press, 2005. A respeito do crédito concedido pela figura do comissário, cita-se: Maria Sylvia de Carvalho Franco, Homens livres na ordem escravocrata. São Paulo: Kairós, 1983; Stanley Stein, Grandeza e decadência do café no Vale do Paraíba. São Paulo: Editora Brasiliense, 1961; Wilson Cano, Raízes da concentração industrial em São Paulo. São Paulo: Hucitec, 1990.
} 
Hilferding, o crédito de circulação é aquele que, em uma função menos complexa, apenas permite a compra da produção na ausência de moeda corrente, de modo a se estabelecer a dívida privada entre contraentes já referida acima. ${ }^{161}$

O crédito de capital, por sua vez, tem como principal função converter dinheiro ocioso em capital monetário ativo. ${ }^{162}$ Afirma o autor que uma parte do capital global dos ciclos produtivos poderá, em determinado momento, se encontrar ocioso. Tal ociosidade, porém, é perniciosa ao desenvolvimento capitalista; a metamorfose desse capital monetário estéril em ativo torna-se uma necessidade para a contínua produção de lucros. Este processo de transferência se desenvolverá mediante o instrumento do crédito em sua nova função, a de reduzir ao mínimo a ociosidade do capital. ${ }^{163}$

Afirma Hilferding que nos processos produtivos descontínuos e vulneráveis (como exemplo cita-se a agricultura) a periodicidade da liberação de capital ocioso é bastante frequente; caberia aqui acrescentar, portanto, que os ciclos da economia cafeeira brasileira do século XIX, cujas mercadorias produzidas dependem de condições sazonais e definem-se pela ineslasticidade da demanda ${ }^{164}$, encaixam-se nesta definição de atividade capaz de gerar ampla disponibilidade de capital ocioso. $\mathrm{O}$ vazamento de capital do núcleo agrícola da economia cafeeira em direção às indústrias embrionárias, explicativo do processo de formação de capital industrial próprio a São Paulo, poderia servir de exemplo empírico dessa transferência. ${ }^{165}$ É possível concluir que se a economia cafeeira era favorável à liberação de capital monetário, era também fonte para a formação do crédito em suas bases primitivas. A própria emergência da necessidade de outros agentes, para além dos bancos nacionais ou estrangeiros, capazes de suprir a demanda por crédito na economia brasileira pode ser identificada como sinal da sua maior dinamização, além de comprovar um aumento da importância do capital financeiro nos circuitos de valorização. ${ }^{166}$

\footnotetext{
${ }^{161}$ HILFERDING, obra citada, p. 90.

$162 \mathrm{O}$ crédito de capital define-se, pois, como uma das atividades constitutivas do capital bancário tratadas por Marx: "A maior parte do capital bancário é, portanto, puramente fictícia e consiste em títulos de dívidas (letras de câmbio), títulos de dívida pública (que representam capital passado), e ações (direitos sobre rendimentos futuros)". MARX, obra citada, vol. III, t. II, cap. XXIX, p. 9.

${ }^{163} \mathrm{O}$ valor de uso do dinheiro é funcionar como capital, isto é, produzir mais valia; o dinheiro que produziu valor torna-se capital realizado e é pago ao prestamista na forma do juro. MARX, obra citada, vol. III, t. I, cap. XXI, p. 267.

${ }^{164}$ NETTO, Antônio Delfim, O problema do café no Brasil. São Paulo: Faculdade de Ciências Econômicas e Administrativas, Universidade de São Paulo, 1959.

${ }^{165}$ CARDOSO DE MELLO, João Manuel, O Capitalismo Tardio. São Paulo: Brasiliense, 1994.

${ }^{166} \mathrm{O}$ surgimento de novas instituições ligadas às finanças altera o quadro da concessão de crédito no período em questão. Cita-se como exemplo de agentes financiadores de então: negociantes, lavradores, comerciantes, "capitalistas", comissários, bancos nacionais e internacionais.
} 
A inexistência de bancos de financiamento no Brasil de então e a restrita política de incentivo ao comércio fez do crédito um mecanismo bastante incerto, fruto sobretudo do excedente das próprias empresas; pode-se dizer que a acumulação de capital no Brasil anterior a 1930 era dependente de lucros não gastos e de saldos ociosos de companhias bem sucedidas, numa época em que a produção do centro do capitalismo já se fazia em larga escala, sob ampla concentração de capital e fontes de financiamento externas às próprias companhias. Com a produtividade voltada para atender as massas, Estados Unidos, Inglaterra, Alemanha e outros países europeus contavam cada vez mais com opções complexas de capitalização, e obtinham recursos via venda de ações nas bolsas de valores, além dos bancos industriais que se coligavam às próprias empresas. $\mathrm{O}$ financiamento da indústria brasileira, bastante incipiente na segunda metade do século XIX, fazia-se via política cambial e tributária. De fato, a política cambial foi, até a década de 1940, o locus privilegiado da política econômica, pois a ausência de um mercado de capitais limitava a transferência de recursos intersetoriais. ${ }^{167}$

Como exemplo dessas transações intersetoriais, citamos as casas importadoras de maquinaria britânicas; elas estimulavam o consumo local de bens de capital via concessão de crédito aos compradores do maquinário que importavam. O capital utilizado para essa operação vinha de bancos ingleses, interessados em financiar indiretamente os consumidores industriais brasileiros. Segundo Richard Graham, "já era praxe que as tradicionais firmas importadoras concedessem um extenso crédito aos compradores brasileiros." ${ }^{168} \mathrm{Em}$ outros momentos as poupanças das firmas financiavam umas às outras, como no caso da Companhia de Seguros Sul América e seu empréstimo de Rs 1.000:000\$000 à Companhia das Docas de Santos, em fevereiro de 1908. ${ }^{169}$

O destino dado aos saldos ociosos das companhias variou ao longo do tempo. As sociedades abertas a partir de 1889, de acordo com seus regulamentos privados, não possuíam ampla liberdade na utilização do capital dos fundos de reserva, podendo apenas engajar-se em investimentos que servissem diretamente às atividades principais. ${ }^{170} \mathrm{Como}$ exemplo tem-se o caso da Mannheimer Versicherunggesselschaft, sociedade alemã cujo estatuto limitava a aquisição de prédios à utilização para atividades da companhia ou para garantia de dívidas ativas. Essa mesma sociedade permitia que seus fundos fossem

\footnotetext{
${ }^{167}$ MALAN, Pedro, Política Econômica e industrialização no Brasil. IPEA, 1977, p. 11.

168 GRAHAM, Richard, obra citada, p. 140

169 BRASIL, Correio Paulistano, Arquivo Público do Estado de São Paulo, 11 de fevereiro de 1908, p. 02.

${ }^{170}$ BRASIL, Actos do poder executivo, 1893 p. 598
} 
empregados na compra de títulos, desde que emitidos pelo governo alemão ou corporações alemãs. A regra, no entanto, admitia exceções no caso da companhia se expandir em direção a outros mercados; se no contexto de exportação de capital os Estados estrangeiros e receptores das firmas exigissem a compra de títulos, públicos ou privados, como condição ao funcionamento em seu território, o estatuto poderia ser flexibilizado. ${ }^{171}$

Nesse capítulo, buscamos inserir a atuação das companhias de seguro no Brasil nos marcos da expansão financeira do centro; vimos o quanto a ampliação do capital estrangeiro rumo a periferia representou o crescimento do investimento externo direto no Brasil, e o quanto essa situação influenciou a conta de capitais e o valor da moeda. Buscaremos agora tratar da política econômica na República, apresentando o contexto de mudanças estruturais pelas quais o país passava no final do século XIX e início do XX.

${ }^{171}$ BRASIL, Actos do poder executivo, 1893 p. 598 


\section{Capítulo 2 - A política econômica na República}

Este capítulo apresentará o momento de construção de uma legislação específica para o setor de seguros no Brasil. A partir do início da década de 1890, quando a economia internacional passava por momentos de inflexão, a parca legislação construída nos tempos do Império não era mais capaz de regular devidamente o setor. A crescente inserção do Brasil nos circuitos de crédito e comércio internacionais naturalmente significou uma complexificação das companhias de seguros, cujo rol de atividades aos poucos deixava de ser predominantemente mercantil e passava a incluir atuações financeiras. Um novo corpo de leis seria promulgado no ano de 1895, mas será apenas em 1901 que as principais mudanças regulatórias do setor terão lugar.

O capítulo também tratará a respeito da política econômica da Primeira República, cujos percalços, sobretudo ao longo da década de 1890, foram bastante marcantes. Desde a proclamação da República, em 1889, até os primeiros anos do século XX, distintas concepções a respeito do funcionamento da economia passaram pelo Ministério da Fazenda, alternando entre si os anos no poder. O país conheceu desde a rígida aplicação do padrão ouro até a pouca ou nenhuma preocupação com o lastro do papel moeda, emitido em quantidades excessivas que acabaram por causar inflação. A profunda conexão entre as possibilidades de atuação macroeconômica do governo e os fluxos monetários internacionais também será apresentada neste capítulo.

Abordaremos o famoso episódio do Encilhamento, emblemático por representar a ânsia do novo governo republicano em liberar a economia brasileira dos entraves do período imperial; apresentaremos as principais consequências do Encilhamento e sua influência na formação do capital industrial brasileiro, chamando atenção à importância que as instituições exerceram sobre esse processo; a crise da superprodução cafeeira e a necessidade do Convênio de Taubaté; e, por fim, os principais aspectos da economia brasileira às vésperas da Primeira Guerra Mundial

\section{$\underline{2.1 \text { - Legislação de seguros durante a República }}$}

A instituição de uma legislação nacional que regulasse o funcionamento das seguradoras ocorre apenas após a Proclamação da República, quando é promulgado o primeiro regulamento de seguros no país com a Lei no 294 , de 5 de setembro de 1895; 
essa legislação, no entanto, regulava apenas o setor dos seguros de vida. ${ }^{172}$ A lei decretada pelo Congresso Nacional e sancionada pelo presidente Prudente de Morais restringia o espaço de atuação das companhias de seguros estrangeiras no Brasil, obrigando-as a uma série de condições e fiscalizações a fïm de poderem funcionar. Em até 60 dias após a publicação da referida lei (Decreto $n^{\circ}$ 294, 05 de setembro de 1895, regulamentado pelo Decreto $\mathrm{n}^{\mathbf{0}} 2153$, em 01 de novembro do mesmo ano), as companhias deveriam apresentar ao governo a relação minuciosa de todos os seguros por elas garantidos e em vigor no território brasileiro, indicando o número da apólice e o nome da pessoa segurada, bem como o capital segurado, o prêmio anual, e o quanto havia de reserva para a dita apólice. $^{173}$

Com a lei decretada, o governo passou a regular de forma mais rígida as companhias. As sociedades de seguro de vida deveriam a partir de então manter todas suas reservas no Brasil, investindo o dinheiro em bens nacionais como imóveis, hipotecas, estradas de ferro, bancos, companhias industriais ou depósitos de longo prazo em bancos que operassem no Brasil. A grande motivação por trás dessas medidas era impedir a remessa de lucros para o exterior, acusação comum desde o grande boom do capital estrangeiro no Brasil, a partir da década de 1860.

O governo preocupava-se com as seguradoras que, ao remeterem parte substantiva de seus ganhos para fora, se tornassem insolventes e incapazes de assumir os compromissos com os sinistros a serem pagos. $\mathrm{O}$ contexto ainda dizia respeito à crise creditícia pós Encilhamento, quando a insolvência se tornou regra e as obrigações quanto aos pagamentos foram, decerto, adiadas. Podemos considerar a regulamentação do setor de seguros de 1895 como exemplo de mudança legislativa levada adiante em resposta a um choque macroeconômico (no caso, a crise originária do Encilhamento), característica comum também ao setor bancário. ${ }^{174}$ De fato, companhias como as britânicas Imperial Fire Insurance e Liverpool \& London Globe Insurance Co. e a portuguesa Garantia remetiam para fora todos os seus prêmios de seguros. Em contraste, a Royal Insurance Company de Liverpool depositava os prêmios recebidos no Brasil. ${ }^{175}$

Após a formulação de uma legislação mais dura, a partir de 1895 a New York Insurance Co. cancelou muitas de suas operações no Brasil. Seu caso tornou-se

\footnotetext{
${ }^{172}$ BRASIL, Decreto n 29405 de setembro de 1895, Actos do Poder Legislativo, Rio de Janeiro, 1895, p. 17.

${ }^{173}$ BRASIL, Actos do poder legislativo, 1895, p. 17.

${ }^{174}$ ABREU, Marcelo de Paiva e FERNANDES, Felipe T., obra citada, p. 05.

${ }^{175}$ ABREU, Marcelo de Paiva e FERNANDES, Felipe T., obra citada, p. 8
} 
emblemático pois além de ter sofrido negativamente as consequências do novo marco regulatório, alguns anos antes a companhia viu um dos seus agentes de vendas nacional abandonar suas funções e abrir um negócio próprio, e concorrente, no Rio de Janeiro do início da República. Após ter representado a companhia norte americana por cerca de dez anos, o negociante carioca Antônio Sanchez tornou-se proprietário de outra companhia de seguros, a Sul América, no ano de $1893 .{ }^{176} \mathrm{O}$ caso foi descrito por Warren Dean como exemplo, no plano dos serviços, de característica comum às atividades fabris, a saber, importadores brasileiros que desafiavam seus fornecedores estrangeiros de mercadorias, tornando-se eles próprios produtores dos artigos antes importados. Dean afirma que devido a sua posição estratégica na estrutura do comércio, além de facilidade de acesso ao crédito e conhecimento dos canais para distribuição do produto acabado, muitos importadores de firmas internacionais realizaram a transição à abertura de manufaturas. ${ }^{177}$

De acordo com a nova legislação, na petição em que solicitasse autorização para funcionar, a companhia deveria assumir a obrigação de manter sua agência principal na cidade do Rio de Janeiro. Após o pedido de autorização, o governo brasileiro tomaria sua decisão baseando-se nas "condições da companhia e garantias que offerecer de solvabilidade e boa administração."178 Nenhuma companhia de seguro estrangeira poderia funcionar no Brasil sem a obtenção da carta patente de declaração, expedida pelo governo e entregue mediante o depósito de Rs 200:000\$000 no Tesouro Nacional via compra de apólices da dívida pública. O depósito serviria como garantia da sociedade para responder às obrigações contraídas. ${ }^{179}$ Apesar do padrão ser de Rs 200:000\$000, encontramos momentos em que as companhias depositaram valores maiores no Tesouro Nacional, como no caso da Companhia Paulista de Seguros, que em julho de 1907 comprou Rs 400:000\$000 em títulos da dívida pública para obter sua carta patente. ${ }^{180}$

A lei previa que o valor total de todas as reservas de apólices vigentes no Brasil de então deveria ser empregado em valores nacionais, tais como bens imóveis, hipotecas, ações de bancos, estradas de ferro, empresas industriais, etc... No caso de as diretorias optarem apenas por deixar seus recursos em bancos, deveriam fazê-lo em estabelecimentos bancários que funcionassem no Brasil e em depósitos de longo prazo; o

\footnotetext{
176 DEAN, Waren, obra citada, p. 30.

${ }^{177}$ Idem, p. 26.

178 BRASIL, Actos do poder executivo, 1895, p. 563.

${ }^{179}$ BRASIL, Actos do poder executivo, 1895, p. 565.

${ }^{180}$ BRASIL, Correio Paulistano, Arquivo Público do Estado de São Paulo, 30 de julho de 1907, p. 6.
} 
sistema financeiro brasileiro da época não contava com aplicações que ultrapassassem o curto prazo, impedindo a formação de uma consistente poupança nacional. ${ }^{181}$

De fato, a baixa propensão da população em reter moeda na forma de depósitos bancários era uma limitação estrutural e impedia que os bancos expandissem seus empréstimos. Segundo os dados de Gustavo Franco, em 1890 a revista The Economist afirmou ser raro no Brasil "o uso de cheques, com o hábito comum ali de reterem os indivíduos em seu poder largas quantias em vez de depositá-las em bancos. Os pequenos negociantes, os taverneiros, por exemplo, no Rio de Janeiro, apenas excepcionalmente depositam nos estabelecimentos. De ordinário, preferem ter consigo o seu dinheiro até a época de pagamentos (...), satisfazendo então os seus débitos com as somas acumuladas em casa no decurso de seis a nove meses. (...) Os agricultores e outros habitantes do interior amuam grandes somas, para satisfazer às suas necessidades; e esse dinheiro leva meses, ou anos, para ir ter aos bancos." 182

O baixo valor para o multiplicador bancário não permitia a ampliação do crédito, e a relação encaixe/depósitos colocava as instituições financeiras em posição bastante vulnerável, numa situação de "inelasticidade do meio circulante." ${ }^{183}$ Além disso, a conjuntura inflacionária constante da década de 1890, fruto das frequentes desvalorizações cambiais, também tornava os depósitos bancários pouco atrativos.

É sob este contexto que a legislação formulada procurou encaminhar as companhias de seguros à manutenção dos recursos no país. As companhias deveriam tomar suas principais decisões de aceite de propostas de seguros, recusando-as ou aceitando-as, via agências filiais no Brasil; o reconhecimento e liquidação dos sinistros e das reclamações dos segurados também deveria receber a palavra final da agência principal, obrigatoriamente situada no Rio de Janeiro. Aquelas que não seguissem tais regras teriam sua permissão de fazer novos contratos de seguros no Brasil cassada, limitando-se a executar os compromissos já vigentes. ${ }^{184}$ As companhias já instaladas, mas que não demandassem nova autorização do governo de acordo com a nova legislação, teriam que recolher junto ao Tesouro nacional 10\% das prestações embolsadas com os contratos ilegais, até que solicitassem a referida autorização. A licença de funcionamento

\footnotetext{
${ }^{181}$ BRASIL, Actos do poder executivo, 1895, p. 564.

182 FRANCO, Gustavo, Reforma monetária e instabilidade durante a transição republicana. Rio de Janeiro: BNDES, 1983

${ }^{183}$ FRANCO, Gustavo. "A primeira década republicana". em Marcelo de Paiva Abreu (org.). A ordem do progresso. Dois séculos de política econômica no Brasil. Rio de Janeiro. Editora Campus, 1995, p. 17. ${ }^{184}$ BRASIL, Actos do poder legislativo, 1895, p. 18.
} 
das companhias poderia ser igualmente cassada no caso das diretorias se recusarem a apresentar os seus livros e documentos aos fiscais do governo ou se nos seus relatórios e balanços fossem identificadas declarações inexatas. ${ }^{185}$

O grau de fiscalização do governo brasileiro sobre as companhias era apresentado pela nova legislação como bastante intenso. Sempre que achasse necessário, o Ministério da Fazenda poderia mandar "pôr empregados de sua confiança proceder a minucioso exame na escripturação das companhias de seguros estrangeiras, a fim de verificar si é feita com a precisa regularidade; si as companhias observam todas as prescripções da lei e deste regulamento, bem como si são exactas as declarações feitas nos seus relatórios, balanços e comunicações officiaes". ${ }^{186}$

Os EUA possuíam legislação semelhante no que diz respeito à necessidade de depósito de fundos em poder do governo; em muitos casos os valores eram mantidos em fundos estaduais. Em 1889, a Equitable Life Assurance Society Company, no Brasil desde 1878, depositou em poder do conferente do Estado de Nova York 100.000 dólares de fundos de $5 \%$ nos EUA, conforme o artigo 463 da lei formulada em 1853, responsável pela incorporação das companhias de seguro de vida e saúde. ${ }^{187}$ A Companhia teve seu estatuto reformulado em maio de 1899, sob a rígida administração de Joaquim Murtinho, quando lhe foi expressamente proibido ressegurar seus seguros em companhias estrangeiras, dentro ou fora do país. ${ }^{188}$

A regulamentação mais desenvolvida era voltada especialmente para o setor de seguros de vida, ramo pouco conhecido no país e, até o início do século XX, dominado por empresas estrangeiras. A lei procurava garantir fiscalização sobre as companhias, com a obrigação de que apresentassem suas operações e que aplicassem os prêmios e as reservas técnicas no país (com imóveis, hipotecas, ações de empresas nacionais ou depósitos a prazo fixo). O receio dos parlamentares que aprovaram a lei era de que empresas estrangeiras, ao remeterem para suas matrizes as reservas aqui acumuladas, encerrassem suas operações gerando elevados prejuízos para os assegurados, sem que as autoridades pudessem intervir legalmente. ${ }^{189}$

\footnotetext{
${ }^{185}$ BRASIL, Actos do poder executivo, 1895, p. 566.

186 Ibidem, p. 566

187 BRASIL, Actos do poder executivo, 1889, p. 45

${ }^{188}$ BRASIL, Actos do poder executivo, 1899, p. 644.

${ }^{189}$ ALVIM, Pedro. A intervenção do Estado no mercado de seguro privado. São Paulo: Edição de Manuais Técnicos de Seguro, 1980, p.60-1; COSTA, Ricardo Cesar Rocha da. "A atividade de seguros nas primeiras décadas da República". ALBERTI, Verena (coord.). Entre a solidariedade e o risco: história do seguro privado no Brasil. Rio de Janeiro: FGV-RJ e Funenseg, 2001, p.37.
} 
Segundo Marcelo de Paiva Abreu e Felipe Fernandes, a legislação de 1895 atingiu resultados positivos, mas trouxe também certos prejuízos. Se por um lado foi bemsucedida em submeter as companhias à regulação do Ministério da Fazenda e em determinar a formação de um amplo fundo de reserva público, por outro exigiu que as contribuições das seguradoras tivessem sempre o mesmo valor, independentemente do tamanho das operações, o que penalizaria as companhias pequenas. Além disso, afirmam os autores, o fato das companhias de seguros de vida serem obrigadas a deixar todas suas reservas em um país periférico como o Brasil, cuja propensão a crises e vulnerabilidade externa eram imensas, poderia desestimular a entrada de capital estrangeiro, tida pelos autores como fundamental ao desenvolvimento do país. A própria exigência de que companhias deixassem suas reservas por aqui tornava-as muito mais aptas às instabilidades e crises do sistema financeiro nacional; basicamente, seria formado um canal de contágio entre as poupanças vítimas de especulação e as próprias companhias. ${ }^{190}$

Em 10 de dezembro de 1901, promulgou-se o Decreto $n^{\circ} 4.270$, conhecido como Regulamento Murtinho. A nova legislação assemelhava-se à lei de setembro de 1895; mantinha grande parte das propostas desta última, mas ampliava a regulamentação estatal para além de companhias de seguro de vida, incluindo seguradoras marítimas e terrestres, nacionais e estrangeiras, já existentes ou que viessem a se organizar no território nacional. Além de ter estendido as normas de físcalização a todas as seguradoras que operavam no país, o Regulamento Murtinho criou a Superintendência Geral de Seguros, diretamente subordinada ao Ministério da Fazenda.

Com a criação da Superintendência foram concentradas em uma única repartição especializada todas as questões atinentes à fiscalização de seguros, antes distribuídas entre diferentes órgãos. Sua jurisdição alcançava todo o território nacional e as fiscalizações realizadas poderiam ser preventivas, exercidas após o exame da documentação da sociedade que requeria autorização para funcionar, ou repressivas, sob a forma de inspeção direta e periódica das companhias. Posteriormente, em 12 de dezembro de 1903, através do Decreto $n^{\circ}$ 5.072, a Superintendência Geral de Seguros foi substituída por uma Inspetoria de Seguros, também subordinada ao Ministério da Fazenda.

${ }^{190}$ ABREU, Marcelo de Paiva e FERNANDES, Felipe T., obra citada, p. 08. 
Futuros Ministros da Fazenda se refeririam ao Regulamento Murtinho e a sua rígida fiscalização do capital estrangeiro como "rigoroso"; ${ }^{191}$ por outro lado, afirmou-se também que o governo brasileiro não poderia ficar indiferente à crescente especulação por parte das empresas internacionais, que assumiam amplos compromissos no Brasil e desviavam as reservas destinadas aos pagamentos de sinistros para fora do país. Sob a administração de Murtinho, empresas cujo capital realizado resultava em Rs 200:000\$000 assumiam responsabilidades no valor de Rs 55.000:000\$000, denotando pouquíssima capacidade de assumir riscos e pagar sinistros. ${ }^{192} \mathrm{O}$ sistema de fiscalização inaugurado tinha como objetivo central acabar com tais circunstâncias. Murtinho argumentou que as companhias estrangeiras eram caracterizadas por possuírem "segredos impenetráveis sobre seus processos, reservas e capitais" ${ }^{193}$

A proibição de acumulação de funções por parte das empresas, distinguindo-se de forma rígida a concessão de seguros de vida dos seguros terrestres ou marítimos, era, segundo Murtinho, característica das seguradoras de outros países e que deveria ser aplicada no Brasil. Para o Ministro, a criação da Superintendência tinha dentre seus objetivos esclarecer o funcionamento das sociedades estrangeiras, cujas atividades no Brasil eram marcadas por pouca publicidade e praticamente nenhuma prestação de contas. Nas suas palavras:

Ao contrario do regimen de maior publicidade, adoptado nos paizes onde ellas tem as suas matrizes, ou naquelles em que funcionam como simples agencias, as companhias estrangeiras no Brazil cercearam sempre suas operações e sua vida de um segredo impenetravel, de modo a não se poder julgar com segurança dos seus processos, dos seus capitaes e das suas reservas. ${ }^{194}$

No Relatório do Ministério da Fazenda de 1901, ao justificar a importância do decreto 4.270, Joaquim Murtinho faz referência ao cenário do Encilhamento: "Companhias havia que compromettiam os capitais entregues à sua guarda em ruinoso jogo de bolsa e outas especulações identicas." 195 Tem-se nesse caso exemplo bastante

\footnotetext{
${ }^{191}$ De fato, Leopoldo de Bulhões classificou a diferenciação jurídica no tratamento de empresas nacionais e estrangeiras, presente na legislação de Murtinho de 1903, como um "vexame". BRASIL, Relatório do Ministério da Fazenda, 1903, p. 109. A legislação proposta pelo ministro de Campos Salles também foi considerada "xenófoba" em ABREU, Marcelo de Paiva e FERNANDES, Felipe T. "The insurance industry in Brazil: a long-term view”. Working paper 10-109, Harvard Business School, 2010, p. 11. 192 BRASIL, Relatório do Ministério da Fazenda, 1903, p. 111.

${ }^{193}$ ABREU, Marcelo de Paiva e FERNANDES, Felipe T., obra citada, p. 10.

194 BRASIL, Relatório do Ministério da Fazenda, 1901, p. 280.

195 BRASIL, Relatório do Ministério da Fazenda, 1901, p. 279.
} 
claro de mudança regulatória levada adiante em resposta a uma conjuntura econômica específica, a saber, a ampla entrada de companhias estrangeiras.

Muitas das firmas estrangeiras que possuíam agências no Rio de Janeiro não aceitaram a nova legislação, e o Relatório do Ministério da Fazenda pressupôs que haviam esgotado suas atividades no país. Praticamente todas tinham sido acusadas de evasão de divisas e remessa ilegal de fundos, justamente no momento em que governo de Campos Salles lutava pela valorização da moeda. A rígida política que tentava frear a evasão de capitais das companhias de seguros era parte constitutiva do principal plano de Joaquim Murtinho, a saber, a retomada do padrão ouro no Brasil; após a fuga das principais firmas estrangeiras o Ministro afirmou que estas sociedades não fariam falta, pois sem elas haveria mais espaço para o desenvolvimento das companhias nacionais.

De fato, entre os anos de 1901 e 1902, quando muitas seguradoras saíram do país, houve grande aumento no valor das emissões de apólices por parte das companhias brasileiras, de Rs 4.600.000\$000 para Rs 17.900.000\$000. ${ }^{196}$ A consolidação do setor nacional de seguros esteve bastante vinculada à promulgação da lei de 1901.

Dentre as companhias nacionais, apenas A Equitativa não aceitou as novas mudanças, e teve sua autorização para funcionar cassada em junho de $1902 .{ }^{197}$ A alemã Nord Deutsche Versicherungs Gesellschaft teve suspensa sua autorização para funcionar em agosto de 1902. ${ }^{198}$ Outras duas, Atalaya e Bonança, entraram em liquidação. Em oposição ao Regulamento Murtinho, especialmente no que diz respeito às regras que impediam às seguradoras concederem seguros de vida e de outras categorias ao mesmo tempo, a Equitativa publicou na imprensa suas opiniões contrárias à nova legislação. ${ }^{199}$

Realizaram o depósito de 200 contos de réis para garantia de suas operações, dentre as sociedades nacionais: Companhia Argos Fluminense, Previdente, Vera Cruz, Confiança, Garantia, Mercurio, Integridade, Indemnisadora, Nacional do Seguro Mutuo, Varegista e União dos Proprietários. Pediram prazo para assumirem tal exigência a Vigilancia, Lloyd Americano, Geral de Seguros e Prosperidade. ${ }^{200}$

Segundo o próprio Joaquim Murtinho, dentre todas as trinta companhias de seguros estrangeiras funcionando no Brasil nos anos de 1901 e 1902, apenas uma constou

\footnotetext{
${ }^{196}$ ABREU, Marcelo de Paiva e FERNANDES, Felipe T., obra citada, p. 11.

${ }^{197}$ BRASIL, Actos do Poder Executivo, 1902, p. 256.

198 BRASIL, Actos do Poder Executivo, 1902, p. 326

${ }^{199}$ BRASIL, Relatório do Ministério da Fazenda, 1901, p. 279

${ }^{200}$ BRASIL, Relatório do Ministério da Fazenda, 1901, p. 279
} 
como tendo pago os impostos devidos na Prefeitura Municipal do Rio de Janeiro; de acordo com os dados apresentados, todas as empresas nacionais, ao contrário, teriam pago.

A partir dos dados coletados no Retrospecto do Jornal do Commercio referentes a 1905, temos que ao final deste ano funcionavam no Brasil 54 companhias de seguros, entre nacionais e estrangeiras, marítimas e terrestres. A distribuição das companhias fazia-se de acordo com a tabela a seguir:

TABELA 4 - Companhias de seguros em funcionamento no Brasil em 1905

\begin{tabular}{|c|c|c|c|}
\hline & $\begin{array}{l}\text { Seguros } \\
\text { marítimos e } \\
\text { terrestres }\end{array}$ & $\begin{array}{l}\text { Seguros de } \\
\text { Vida }\end{array}$ & \\
\hline $\begin{array}{l}\text { Companhias } \\
\text { nacionais }\end{array}$ & 36 & 4 & \\
\hline $\begin{array}{l}\text { Companhias } \\
\text { estrangeiras }\end{array}$ & 13 & $1 *$ & \\
\hline Total & 49 & 5 & 54 \\
\hline
\end{tabular}

*New York Life Insurance Company. Fonte: BRASIL, Retrospecto do Jornal do Commercio. Rio de Janeiro: Typographia do Jornal do Commercio de Rodrigues, 1906, p. 88.

No que diz respeito às companhias de seguros marítimos e terrestes funcionando no Brasil de 1905, apresentamos os seguintes dados: 
TABELA 5 - Depósitos, prêmios e sinistros de companhias de seguros marítimos e terrestres, nacionais e estrangeiras, 1905 (valores em mil réis)

\begin{tabular}{|c|l|l|l|l|}
\hline & $\begin{array}{l}\text { Depósito no } \\
\text { Tesouro } \\
\text { Nacional }\end{array}$ & $\begin{array}{l}\text { Total de valores } \\
\text { segurados }\end{array}$ & $\begin{array}{l}\text { Total dos } \\
\text { prêmios } \\
\text { recebidos }\end{array}$ & Sinistros pagos \\
\hline $\begin{array}{l}\text { Companhias } \\
\text { nacionais }\end{array}$ & $4.950: 000 \$ 000$ & $2.252 .354: 527 \$ 000$ & $12.274: 889 \$ 000$ & $6.286: 251 \$ 000$ \\
\hline $\begin{array}{l}\text { Companhias } \\
\text { estrangeiras }\end{array}$ & $653: 335 \$ 000$ & $476.279: 433 \$ 000$ & $2.084: 664 \$ 000$ & $1.057: 804 \$ 000$ \\
\hline Total & $5.603: 335 \$ 000$ & $2.738 .633: 960 \$ 000$ & $14.359: 566 \$ 672$ & $7.344: 056 \$ 000$ \\
\hline
\end{tabular}

Fonte: BRASIL, Retrospecto do Jornal do Commercio. Rio de Janeiro: Typographia do Jornal do Commercio de Rodrigues, 1906, p. 88.

Dentre as companhias que compõem os dados da tabela acima, 15 tinham sua sede no Rio de Janeiro, 7 no Pará, 2 no Maranhão, 4 em Pernambuco, 2 na Bahia, 5 no Rio de Grande do Sul, 7 na Inglaterra, 1 na França e 5 na Alemanha. ${ }^{201}$ No final do ano de 1905 , as companhias de seguros marítimos e terrestres nacionais possuíam o capital realizado de Rs 20.331:455\$000, enquanto as estrangeiras eram representadas pelo baixo valor de Rs 200:000\$000; as primeiras possuíam reservas de Rs 9.178:755\$934, enquanto os valores referentes às reservas das segundas não foram computados. ${ }^{202} \mathrm{~A}$ partir dos dados apresentados podemos deduzir que as companhias de seguros nacionais possuíam maior representatividade no setor do que as estrangeiras, que não possuíam a mesma capacidade de inserção no mercado doméstico. O baixo valor do capital realizado no Brasil por parte das firmas estrangeiras e ausência do valor total de suas reservas possui estreita relação com a queda do Regulamento Murtinho em 1903 e o início de uma Legislação para o setor de seguros estrangeiros, marítimos e de vida, muito mais branda, sob administração de Leopoldo de Bulhões, como veremos a seguir neste mesmo capítulo.

Para o caso das companhias de seguros de vida, temos os seguintes dados:

\footnotetext{
${ }^{201}$ BRASIL, Retrospecto do Jornal do Commercio. Rio de Janeiro: Typographia do Jornal do Commercio de Rodrigues, 1906, p. 88.

202 Ibidem, p. 88
} 
TABELA 6- Reservas, seguros efetuados, pagos e em vigor para companhias de seguros de vida, nacionais e estrangeiras, 1905 (valores em mil-réis)

\begin{tabular}{|l|l|l|l|l|}
\hline & $\begin{array}{l}\text { Reservas } \\
\text { técnicas }\end{array}$ & $\begin{array}{l}\text { Seguros } \\
\text { efetuados }\end{array}$ & Seguros em vigor & Sinistros pagos \\
\hline $\begin{array}{l}\text { Companhias } \\
\text { nacionais }\end{array}$ & $23.721: 322 \$ 000$ & $43.131: 504 \$ 000$ & $152.154: 536 \$ 000$ & $2.787: 838 \$ 000$ \\
\hline $\begin{array}{l}\text { Companhias } \\
\text { estrangeiras* }\end{array}$ & $663.842 \$ 000$ & $7.804: 689 \$ 000$ & $12.959: 045 \$ 000$ & $85.704 \$ 000$ \\
\hline Total & $24.385: 164 \$ 000$ & $50.936: 193 \$ 000$ & $165.113: 581 \$ 000$ & $2.873: 542 \$ 000$ \\
\hline
\end{tabular}

*Apenas uma, New York Life Insurance Company. Fonte: BRASIL, Retrospecto do Jornal do Commercio. Rio de Janeiro: Typographia do Jornal do Commercio de Rodrigues, 1906, p. 88.

A maior parte das companhias de seguro de vida em funcionamento no Brasil em 1905, incluindo a New York Life Insurance Company, operava através do sistema de mutualidade, isto é, via contribuição coletiva de quotas capazes de formar uma poupança coletiva, a serem resgatadas pelos mutuários. ${ }^{203}$

A partir dos dados da Tabela 4, concluímos que o setor de seguros de vida no Brasil de então era menos desenvolvido que o de seguros marítimos e terrestres, estes últimos mais bem estabelecidos no território nacional e estreitamente conectados com os fluxos de comércio aos quais a economia brasileira estava exposta. A Tabela 6 complementa a análise específica do setor de seguros de vida ao nos apresentar a controle que as firmas nacionais possuíam no setor, dotado nessa época de uma única sociedade estrangeira, a New York Life Insurance Company.

Após apresentarmos os dados a respeito das companhias de seguros em funcionamento no Brasil ao final do ano de 1905, temos abaixo novos valores referentes à 1906; as tabelas 4, 5 e 6 apresentam dados do Retrospecto do Jornal do Commercio, enquanto a tabela 7, logo abaixo, possui dados do Relatório do Ministério da Fazenda de 1906.

${ }^{203}$ BRASIL, Retrospecto do Jornal do Commercio. Rio de Janeiro: Typographia do Jornal do Commercio de Rodrigues, 1906, p. 88. 
TABELA 7 - Capital emitido, capital realizado e depósito no Tesouro das companhias de seguros, 1906 (valores em mil réis)

\begin{tabular}{|c|c|c|c|}
\hline Nome & $\begin{array}{l}\text { Capital emitido } \\
\text { no Brasil }\end{array}$ & $\begin{array}{l}\text { Capital realizado } \\
\text { no Brasil }\end{array}$ & $\begin{array}{l}\text { Depósito no } \\
\text { Tesouro Federal }\end{array}$ \\
\hline Vera Cruz & 1.000:000\$000 & 500:000\$000 & 200:000\$000 \\
\hline Mercúrio & $2.000: 000 \$ 000$ & $910: 135 \$ 000$ & 200:000\$000 \\
\hline Confiança & $2.000: 000 \$ 000$ & 500:000\$000 & 200:000\$000 \\
\hline Argos Fluminense & $3.000: 000 \$ 000$ & 1.200:000\$000 & 200:000\$000 \\
\hline $\begin{array}{l}\text { Nacional de } \\
\text { Seguros Mútuos } \\
\text { contra Fogo }\end{array}$ & Mutualidade & & 200:000\$000 \\
\hline Garantia & 2.500:000\$000 & 500:000\$000 & $200: 000 \$ 000$ \\
\hline Previdente & 2.500:000\$000 & 1.000:000\$000 & 200:000\$000 \\
\hline Indemnizadora & $1.000: 000 \$ 000$ & 400:000\$000 & 200:000\$000 \\
\hline $\begin{array}{ll}\text { União } & \text { dos } \\
\text { Proprietários } & \\
\end{array}$ & 500:000\$000 & $250: 000 \$ 000$ & 200:000\$000 \\
\hline Integridade & $2.000: 000 \$ 000$ & 500:000\$000 & $200: 000 \$ 000$ \\
\hline $\begin{array}{l}\text { União Comercial } \\
\text { dos Varegistas }\end{array}$ & $1.000: 000 \$ 000$ & 250:000\$000 & 200:000\$000 \\
\hline Lloyd Americano & 1.000:000\$000 & 400:000\$000 & 200:000\$000 \\
\hline Geral & $2.000: 000 \$ 000$ & 4000:000\$000 & $200.000 \$ 000$ \\
\hline Minerva & $2.000: 000 \$ 000$ & $300: 000 \$ 000$ & 200:000\$000 \\
\hline $\begin{array}{l}\text { Equitativa dos } \\
\text { Estados Unidos do } \\
\text { Brasil }\end{array}$ & & & \\
\hline Brasil & $1.000: 000 \$ 000$ & $400: 000 \$ 000$ & $150: 000 \$ 000$ \\
\hline Amazonia & $1.000: 000 \$ 000$ & 1.000:000\$000 & \\
\hline Lealdade & $1.000: 000 \$ 000$ & 1.000:000\$000 & \\
\hline Lloyd Paraense & 1.000:000\$000 & 1.200:000\$000 & \\
\hline Commercial & $600: 000 \$ 000$ & 6000:000\$000 & 200:000\$000 \\
\hline Alliança & $1.000: 000 \$ 000$ & 1.000:000\$000 & 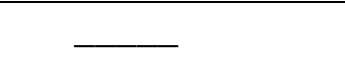 \\
\hline Paraense & 600:000\$000 & $600: 000 \$ 000$ & \\
\hline Segurança & $2.000: 000 \$ 000$ & 1.997:800\$000 & - \\
\hline Maranhense & $1.000: 000 \$ 000$ & $200: 000 \$ 000$ & 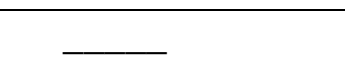 \\
\hline Esperança & $1.000: 000 \$ 000$ & $150: 000 \$ 000$ & $200: 000 \$ 000$ \\
\hline Amphitrite & $1.000: 000 \$ 000$ & 400:000\$000 & 200:000\$000 \\
\hline $\begin{array}{l}\text { Phenix } \\
\text { Pernambucana }\end{array}$ & $1.000: 000 \$ 000$ & $300: 000 \$ 000$ & $200: 000 \$ 000$ \\
\hline Thetys & $500: 000 \$ 000$ & $300: 000 \$ 000$ & $200: 000 \$ 000$ \\
\hline
\end{tabular}




\begin{tabular}{|l|l|l|l|}
\hline Interesse Público & $2.000: 000 \$ 000$ & $800: 000 \$ 000$ & $200: 000 \$ 000$ \\
\hline Rio Grandense & $1.000: 000 \$ 000$ & $400: 000 \$ 000$ & $200: 000 \$ 000$ \\
\hline
\end{tabular}

Fonte: BRASIL, Relatório do Ministério da Fazenda, 1906, p. 54 e 55.

É fácil notarmos a pressão das companhias de seguros nacionais, que se manifestavam contra a ausência de regulação das empresas estrangeiras, situação que durou até o ano de 1895. Muitas se manifestaram na imprensa de forma veemente contra a concorrência do capital estrangeiro. No Relatório da Fazenda de 1901, Murtinho cita o caso da diretoria da Companhia Vigilancia, que publicou em seu relatório de 1891 o seguinte texto:

As companhias nacionais continuam assoberbadas pela concurrencia de agencias das companhias estrangeiras, e nada teríamos a oppor a essa liberdade, si, niveladas quanto a direitos, também estivessem a nós equiparadas a deveres. Infelizmente, assim não succede, e dessa desigualdade emanam taes inconvenientes, que chegam a fallar ao patriotismo do poder publico, pedindo a sua intervenção nesse grave e momentoso assunpto. ${ }^{204}$

A esse respeito também tratou a Companhia Prosperidade:

Esforçam-se as companhias nacionaes por merecer a confiança de todas as classes, como o demonstram os seus relatórios; infelizmente, porém, continuamos a encontrar os maiores embaraços na propaganda feita em favor das companhias estrangeiras. $\mathrm{O}$ exportador não se contenta com o seguro de toda a exportação de café, ainda impõe ao ensacador a ao commissairio o seguro em transito pelos armazéns a titulo de maior garantia. Parece, à primeira vista, não haver diferença alguma para o commercio, em segurar nas companhias estrangeiras de preferencia às nacionaes, mas é um engano que a razão esclarecida dos negociantes não tardará em reconhecer, mormente quando se capacitarem de que não prejudicam somente companhias nacionaes, mas sim também a praça desta capital, porque mais de dous mil contos de prêmios são enviados anualmente ao estrangeiro, não fallando no seguro de exportação que monta a milhares de contos. ${ }^{205}$

Após a entrada em vigor do seu Regulamento, Joaquim Murtinho buscou defender a legislação sancionada e afirmou que o capital realizado por companhias nacionais da praça do Rio de Janeiro havia aumentado, passando de Rs 4.200:000\$000 para Rs

${ }^{204}$ BRASIL, Relatórios do Ministério da Fazenda, 1901, p. 282

${ }^{205}$ BRASIL, Relatórios do Ministério da Fazenda, 1901, p. 283 
6.500:000\$000. Ao referir-se ao funcionamento das companhias de seguros nacionais para o ano de 1900, o Ministro apresenta os seguintes dados: sinistros equivalentes a Rs 1.200:000\$000 sobre uma responsabilidade assumida de Rs 952.048:000\$000, produzindo como prêmios cerca de Rs 3.800:000\$000. Os acionistas obtiveram prêmios que variaram entre 8\% a 40\% ${ }^{206}$ Segundo Marcelo de Paiva Abreu e Felipe Fernandes, o comportamento do Ministro Joaquim Murtinho se coadunava com outras experiências na América Latina de então, onde governos estabeleceram, nas palavras dos autores, "cruzadas" contra o capital estrangeiro e sobretudo contra as companhias de seguros. ${ }^{207}$

Alguns anos depois, em 1908, companhias de seguros brasileiras vangloriavamse na imprensa de "não drenarem seu capital para fora do país". Segundo a diretoria da Companhia Sul América:

Por seu intermédio não se drena capital do Brasil para o exterior, a não ser o que corresponda a dividendos de accionistas, que ninguém pode impedir de residirem no extrangeiro, e o necessário para aí manter suas agencias. A Sul América emprega aqui seus capitais, em títulos da divida publica, primeiras hypotecas e papeis de crédito facilmente realizável. ${ }^{208}$

A permanência desse capital no Brasil exercia um impacto direto no câmbio, na composição do mercado de capitais nacional e nas possibilidades de financiamento. A partir do trecho cima transcrito podemos concluir que a importância da compra dos títulos da dívida pública nacional ia além do financiamento do Estado, da garantia de acumulação de capital privado e da formação de uma poupança nacional; aos poucos os depósitos realizados pelas companhias de seguros no Tesouro Federal tornaram-se sinônimo de boas condições de solvência das seguradoras, e passaram a ser publicizados por essas últimas. Uma disputa ocorrida na imprensa entre as companhias brasileiras Sul América, Equitativa e Garantia da Amazônia, com a primeira acusando as últimas de pouco confiáveis em suas reservas e poupanças, é um exemplo bastante emblemático.

Nos exemplares do jornal Correio Paulistano de março de 1908 podemos ler o desenrolar da disputa. A Equitativa publicou sucessivos textos com a manchete "Superioridade da Equitativa sobre a Sul América", enquanto esta última se referia ao

\footnotetext{
${ }^{206}$ BRASIL. Relatório do Ministério da Fazenda, 1901, p. 284

207 ABREU, Marcelo de Paiva e FERNANDES, Felipe T., obra citada, p. 10.

208 BRASIL, Correio Paulistano, Arquivo Público do Estado de São Paulo, 23 de fevereiro de 1908 , p. 02. 
mal estado das contas da concorrente com o título: “Comparações necessárias!! Verdade às claras!!."209

A rivalidade entre a Sul América e a Equitativa se acirrou, e as acusações da primeira contra a segunda passaram a se referir à ausência dos depósitos no Tesouro Federal. Citaremos alguns exemplos:

Não consta na Caixa de Amortização que a Equitativa tenha apólices da dívida pública. Até hoje e apesar de intimidada pelo fiscal de seguros do governo federal, a Equitativa não fez, como é de lei, o depósito de 200 contos em apólices no Thesouro, para poder funcionar, a exemplo de suas congeneres. Para fugir desse depósito legal, ella lança mão de chicanas, allega que a lei não tem effeito retroactivo, diz uma inanidade de cousas, e afinal não entra com o deposito para o Thesouro da República. ${ }^{210}$

\section{Continua a Sul América:}

Compare-se com a seriedade da Sul América, que possue mais de 6 mil contos em apólices da dívida pública. E a Sul América não fez questão, entrou logo com o depósito de 200 contos para o Thesouro, é este seu acto, além de ser uma obediência à lei, despertou todas as sympathias e a confiança do público em favor da Sul América. A Equitativa prefere questionar, levar mais de 8 annos a gastar o dinheiro dos segurados do que "dar o braço a torcer" perante o público, do que cumprir com uma justa disposição de lei.

E si a Equitativa possue apólices da dívida pública, que faça constar isso nos jornaes, nos seus balanços, balanços que há perto de 3 annos os segurados ignoram. Tendo como deve ter um movimento de despeza, diga qual a sua receita? A sua fortuna? Quantos prédios possue? ${ }^{211}$

A discussão termina com a Sul América questionando onde a Equitativa teria empregado os valores declarados em seus balanços e, por fim, acusando-a de não possuir os valores que declara na imprensa:

\footnotetext{
${ }^{209}$ BRASIL, Correio Paulistano, Arquivo Público do Estado de São Paulo, 04 de março de 1908, p. $03 ; 06$ de março de 1908, p. 05.

${ }^{210}$ BRASIL, Correio Paulistano, Arquivo Público do Estado de São Paulo, 12 de março de 1908, p. 06.

211 Ibidem, p. 06
} 
Ninguém sabe onde a Equitativa empregou 3.879:715\$500, contando do seu último balanço, publicado em 1904! Quanto tem empregado em hypotecas de predios? Venha pela imprensa e diga que tem uma - uma só já satisfaz a curiosidade do publico.

Qual! A Equitativa não possue cousa alguma: o seu último balanço, dado em 1904, accusou um saldo de 3.879:715\$500, constante unicamente de um documento de letras descontadas de um banco que falliu e que ainda é liquidante o atual presidente da Equitativa. ${ }^{212}$

As acusações continuavam, com a Sul América apontando as altas cifras dos salários dos presidentes da Equitativa e a ausência de uma estrutura democrática na composição dos votos dos segurados. Dentre as acusações mais fortes, no entanto, está a afirmativa de que a Equitativa teria subornado a imprensa para que publicasse seus balanços como sustentáveis e superavitários. ${ }^{213}$

Podemos considerar o referido conflito como uma emblemática disputa entre duas companhias nacionais de porte razoável, ambas preocupadas com o domínio do mercado, com a destruição da concorrência e, acima de tudo, com a construção de uma legitimidade para com o público, característica fundamental para a prosperidade de instituições financeiras. Adjetivos como moralizada, prestigiosa e inatacável, usados pela Sul América para definir a si mesma, ${ }^{214}$ bem como referências a valores, dignidade e orgulho, presentes no seu discurso de acusação, são bastante frequentes; por se tratarem de instituições administradoras de dinheiro de terceiros e formadoras de poupanças, era natural que em um incipiente mercado de capitais como o brasileiro de então houvesse razoável nível de desconfiança perante os bancos e as companhias de seguros, sua solvência e capacidade de cumprir com obrigações.

A desconfiança e receio por parte do público em relação às companhias de seguros, sobretudo dos brasileiros, pouco familiarizados com o funcionamento de estruturas financeiras, podem ser constatados por casos apresentados na imprensa. Em setembro de 1905, o Correio Paulistano publicou texto de um leitor denunciando as más condições financeiras da empresa estrangeira New York Insurance Company; a companhia era acusada de realizar operações de empréstimo fictícias, de pagar salários desproporcionais ao presidente e ao corpo administrativo, e de não possuir suficientes reservas para

\footnotetext{
${ }^{212}$ BRASIL, Correio Paulistano, Arquivo Público do Estado de São Paulo, 12 de março de 1908, p. 06.

${ }^{213}$ BRASIL, Correio Paulistano, Arquivo Público do Estado de São Paulo, 12 de março de 1908, p.06

${ }^{214}$ Ibidem, p. 06
} 
pagamento de sinistros. Dado o "avultuado número de segurados da New York Life Insurance no Brasil", o governo solicitou explicações a Thomas Buckner, vice-presidente da companhia em Nova York. ${ }^{215}$ Como resposta vinda da sede nos EUA, a companhia alegava um ativo de mais de 300 milhões de dólares, uma reserva de 47 milhões de dólares, perfeitas condições de funcionamento e total capacidade de solvência; também aproveitava a oportunidade para questionar as reais condições de funcionamento da sua principal concorrente, a Equitable, que supostamente teria sérias dificuldades de administração. ${ }^{216}$

Além das disputas entre o capital, nacional e estrangeiro, em busca de espaço no emergente mercado de seguros brasileiro, constatamos sucessivos casos de fraudes no setor, a maior parte noticiada pela imprensa.

Em maio de 1889, o jornal The Rio News publicou a respeito de uma grande tentativa de fraude envolvendo a carga de mercadorias de um navio, avaliada em cerca de Rs 21.000\$000. A mercadoria havia saído da região de Penedo, no Sul do estado do Rio de Janeiro, e encaminhava-se em direção ao porto da capital, quando os subscritores e segurados receberam a notícia de que estava sendo planejada a destruição do navio. Os representantes da seguradora, cujo nome não foi revelado na notícia publicada, telegrafaram para o dono do navio a fim de cancelar o seguro; apesar da situação, as contas do carregamento e as letras de câmbio contra o navio puderam ser recebidas e honradas. $^{217}$

Anos depois no Rio de Janeiro, em fevereiro de 1904, foi noticiada a existência de um "sindicato" que se propunha a montar diversas casas de secos e molhados, segurandoas depois por altas somas em companhias de seguros. Em seguida as casas eram incendiadas e as companhias obrigadas a pagarem o valor dos seguros feitos; em outros casos, os armazéns de secos e molhados decretavam falência. ${ }^{218}$ No mesmo ano de 1904 encontramos exemplos de publicações nos jornais denunciando o não pagamento de sinistros pelas companhias, como no caso de Alexandre Herculano Guilherme, que entrou com uma ação contra a Companhia de Seguros Lloyd Americano afim de obter desta última Rs 23:000\$000 de um seguro feito anos antes.

\footnotetext{
215 BRASIL, Correio Paulistano, Arquivo Público do Estado de São Paulo, 17 de setembro de 1905, p. 04. ${ }^{216}$ BRASIL, Correio Paulistano, Arquivo Público do Estado de São Paulo, 17 de setembro de 1905, p. 04. ${ }^{217}$ BRASIL, The Rio News. Rio de Janeiro: A. J. Lamoureux , 27 de maio de 1889, p. 02

${ }^{218}$ BRASIL, Correio Paulistano, Arquivo do Estado de São Paulo, 22 de fevereiro de 1904, p. 02.
} 
Um ano mais tarde, em janeiro de 1905, o Correio Paulistano publicou os detalhes do julgamento do negociante Dante Bertuccelli, membro de uma "quadrilha de incendiários" que operou por cerca de um ano e meio no bairro do Brás, em São Paulo. Dante foi considerado responsável pelo incêndio da noite de 23 de junho de 1903, que destruiu um armazém de secos e molhados na rua Monsenhor Andrade, esquina com a Benjamin de Oliveira. ${ }^{219}$

Citaremos ainda um outro exemplo de fraude: em novembro de 1905, foi anunciada a notícia de um incêndio proposital realizado na Alameda dos Andradas, em São Paulo; a proprietária de um imóvel deixara vestígios de ter incendiado a própria casa, como panos embebidos em querosene, e latas e garrafas do inflamável. Seu filho, no entanto, ao ser ouvido pela polícia, atribuiu a origem do fogo à inimigos seus. A casa, avaliada em Rs 15:000\$000, estava segura em Rs 9:000\$000 pela companhia Vera Cruz, e em Rs 7:000\$000 pela Previdente. ${ }^{220}$

Segundo o jornal Correio Paulistano, "a pacata população de São Paulo" ficou profundamente marcada pelo caso Cerveira, fraude ocorrida em setembro de 1901 mas julgada e esclarecida sete anos depois: ${ }^{221}$

Ninguém houve que por elle não se interessasse; São Paulo inteiro commentou-o e devorava as edições das folhas que melhores detalhes encerravam nas suas longas descripções. Francisco Henrique Cerveira, a alma de toda essa mystificação, a cabeça pensante da quadrilha de intelligentes estellionatários, celebrizou-se logo, como era natural. ${ }^{222}$

O jornal afirmou ainda que Francisco Henrique Cerveira "illudiu com rara habilidade a companhia de seguros Sul América", e logo em seguida engajou-se ao lado de nova quadrilha em um crime contra a companhia Garantia da Amazônia. Após a morte do segurado Manuel Bernardino Gonçalves, a companhia concedeu o pecúlio referente ao seu seguro de vida; algum tempo depois, após investigação policial, descobriu-se que o referido segurado não estava morto e em seu caixão havia dois sacos de terra. A

\footnotetext{
${ }^{219}$ BRASIL, Correio Paulistano, Arquivo Público do Estado de São Paulo, 14 de janeiro de 1905, p. 02. ${ }^{220}$ BRASIL, Correio Paulistano, Arquivo Público do Estado de São Paulo, 28 de novembro de 1905, p. 04 .

${ }^{221}$ BRASIL, Correio Paulistano, Arquivo Público do Estado de São Paulo, 27 de março de 1908, p. 02.

222 Ibidem, p. 02
} 
quadrilha se beneficiara do valor do seguro, dando a Manuel uma pequena porcentagem do total. ${ }^{223}$

A versão oficial das seguradoras com frequência incluía a desconfiança de fraudes e quadrilhas que forjavam sinistros. Em julho de 1906, as suspeitas recaíram sobre uma fábrica de tabaco do Rio de Janeiro, que, após ter sofrido terrível incêndio, reivindicou seu altíssimo seguro de Rs 500:000\$000, valor verossímil para a proteção de estabelecimentos fabris à época. ${ }^{224}$ Situações contrárias também ocorriam; quando as seguradoras se recusavam a pagar sinistros a acidentes, a imprensa tendia a noticiar e os casos ganhavam certa notoriedade. Na edição de 11 agosto de 1909, o Correio Paulistano relatou o processo pelo qual respondiam na Segunda Vara da capital paulista as companhias Integridade e União Commercial dos Varegistas. Após se recusarem a pagar o sinistro de uma fábrica de chapéus incendiada, ambas as companhias teriam que entregar, cada uma, a quantia de Rs 37:500:000 ao proprietário do estabelecimento. ${ }^{225}$

No que diz respeito à legislação recém promulgada e às companhas estrangeiras, seus rumos ainda sofreriam novas mudanças. Em 1903, sob a presidência de Rodrigues Alves, Leopoldo de Bulhões assumiu o Ministério da Fazenda. Apesar de sua administração pouco ter mudado em relação à de Joaquim Murtinho, Bulhões apresentou divergências com este último no que diz respeito à regulação do capital estrangeiro. Afirmou o novo Ministro da Fazenda:

Porque companhias nacionaes desviavam as reservas destinadas ao pagamento de sinistros em ruinosas especulações da Bolsa, acarretando desastrosas liquidações; porque outras, extrangeiras, praticavam tal ou qual abuso, a necessidade de legislar levou-nos a exigências, que se poderiam classificar de impertinentes, se não constituíssem antes verdadeiras disposições proibitivas. ${ }^{226}$

$\mathrm{O}$ argumento da ausência de capitais esteve por trás dos apelos pela mudança de legislação:

Sem attenção às condições de tempo e de logar, e, principalmente, a de sermos um país novo, onde os capitais escasseam sempre, sendo necessario recorrer constantemente ao

\footnotetext{
${ }^{223}$ BRASIL, Correio Paulistano, Arquivo Público do Estado de São Paulo, 27 de março de 1908, p. 02

${ }^{224}$ BRASIL, Correio Paulistano, Arquivo Público do Estado de São Paulo, 03 de julho de 1906, p. 05.

${ }^{225}$ BRASIL, Correio Paulistano, Arquivo Público do Estado de São Paulo, 11 de agosto de 1909, p. 06.

${ }^{226}$ BRASIL. Relatório do Ministério da Fazenda, 1902, p. 101
} 
extrangeiro, creamos uma legislação, cujo menor inconveniente é ser de todo ponto illusoria nos seus intuitos. ${ }^{227}$

Leopoldo Bulhões se referia ainda à impossibilidade de que os saldos ociosos das companhias de seguros serem produtivamente empregados no Brasil, dada a indisponibilidade de investimentos e a pouca quantidade de negócios num país tão jovem:

Essa legislação, se afugenta do país as companhias extrangeiras, pela impossibilidade de empregarem nelle todas as reservas que produzirem todas as suas apólices (...), não tem ao menos o merecimento de evitar que os cidadãos desse paiz façam inscrever os seus seguros em companhias estrangeiras, com selos fora dele ${ }^{228}$

Cabe aqui considerarmos a percepção do novo Ministro da Fazenda no que diz respeito às possibilidades de investimento que o Brasil da época oferecia; ser um país recém-saído do pacto colonial, pouco industrializado e com ausência de capitais parecia, para Bulhões, características que apenas afastariam companhias estrangeiras, que pela pouca diversificação produtiva deixariam de investir no nosso território. Por outro lado, a capacidade de absorção de novos capitais por uma economia periférica do século XIX pode ser considerada muito mais ampla e abrangente em relação ao centro, sobretudo a partir da crise da década de 1870; o debate a esse respeito está presente na discussão indireta travada entre Joaquim Murtinho e Leopoldo Bulhões. Em última instância, temse entre ambos os Ministros diferentes visões a respeito do investimento em uma economia jovem e periférica.

Para Celso Furtado, Joaquim Murtinho pode ser considerado como o primeiro Ministro da Fazenda brasileiro a adotar um conjunto de medidas econômico-financeiras coordenadas e visando a um objetivo definido, a saber, a redução da pressão sobre a balança de pagamentos, a estabilização do valor da moeda, e o retorno do acesso ao crédito exterior. A política econômica levada adiante entre 1898 e 1902 refletia um novo equilíbrio de forças na sociedade brasileira, não mais inteiramente assentada numa estrutura agrícola. Novos grupos de pressão e uma ascendente classe assalariada e urbana, capaz de se organizar em levantes militares e revoltas, posicionaram-se contra a contínua depreciação cambial como mecanismo de proteção do núcleo agrícola. As disputas em

\footnotetext{
${ }^{227}$ BRASIL. Relatório do Ministério da Fazenda, 1902, p. 102

${ }^{228}$ BRASIL. Relatório do Ministério da Fazenda, 1902, p. 101 
torno do câmbio no Brasil passariam cada vez mais a refletir a ascensão política de novos grupos socais cujas rendas não derivavam diretamente da propriedade. ${ }^{229}$

Sabemos que após a promulgação do Regulamento Murtinho o mercado de seguros no Brasil conheceu maior espaço para firmas nacionais, sobretudo após a saída de muitas companhias estrangeiras. Como dito anteriormente, essa situação levou a um aumento da emissão de capital por parte de seguradoras nacionais que, entre 1901 e 1902, elevaram o capital emitido em 4,6 mil contos, de 13,3 mil contos para 17,9.230 Já em 1903 muitas firmas estrangeiras passam a pressionar o congresso brasileiro a favor do fim da legislação restritiva, posicionando-se contra a legislação de Joaquim Murtinho. A pressão foi bem-sucedida e o Decreto 4270 caiu, sendo substituído lei 5072, de 12 de dezembro de 1903.

A Superintendência Geral de Seguros Terrestres e Marítimos deixou de existir e foi substituída por uma instituição mais modesta, dependente do Ministério da Fazenda e sob o título de Inspetoria de Seguros. Funcionariam ainda subinspetorias regionais, em oposição ao Regimento, considerado excessivamente centralizador. ${ }^{231}$ Essa nova legislação abriu espaço para a existência dos resseguros e instituiu mudanças na quantidade de reservas que deveriam permanecer no Brasil - $20 \%$ no caso de seguros marítimos e $100 \%$ no caso de seguros de vida.

A Inspetoria, bem como a própria Superintendência anterior, era financiada pelas próprias companhias, pois o órgão não possuía independência financeira e tornou-se capaz de se auto sustentar apenas em 1911. ${ }^{232}$ Segundo Leopoldo de Bulhões:

Envolver o governo na gestão dos negócios das companhias, seria attribuir-lhe para com terceiros uma responsabilidade, pelo menos moral, que não lhe cabe, não se devendo supor que ele a possa assumir. (...) o rigorismo excessivo occasionaria o retrahimento de capitaes e o prejuízo da própria rendas do Thesouro ${ }^{233}$

O Congresso Nacional aprovou as modificações propostas pela legislação de 1903; de fato, houve até mesmo a flexibilização das regras por parte do Legislativo. O documento enviado previa que as companhias de seguros terrestres e marítimas não

\footnotetext{
${ }^{229}$ FURTADO, Celso, obra citada, p. 204.

${ }^{230}$ BRASIL. Relatório do Ministério da Fazenda, 1902, p. 101

${ }^{231}$ BRASIL. Relatório do Ministério da Fazenda, 1903, p. 107.

${ }^{232}$ ABREU, Marcelo de Paiva e FERNANDES, Felipe T., obra citada, p. 11. A submissão direta da Superintendência e das Inspetorias ao controle do capital privado ilustra quão incipientes eram as instituições públicas, ainda em formação, no Brasil do início da República.

${ }^{233}$ BRASIL. Relatório do Ministério da Fazenda, 1903, p. 108
} 
assumissem riscos em cada seguro isolado superiores a $40 \%$ de seu capital. Segundo o texto aprovado pelo Congresso:

A essas companhias, porem, será lícito excederem esses limites, desde que o excesso seja, no mesmo dia da emissão da apólice, ressegurado em outra companhia que esteja autorizada a funcionar e isto conste da apólice emitida. ${ }^{234}$

O artigo 70/1903 estabelecia que todas as companhias de seguro nacionais e estrangeiras eram iguais perante a lei; segundo Leopoldo de Bulhões, a distinção anterior, de autoria de Joaquim Murtinho, era "um vexame, ou, melhor, uma lesão de direito, contra a qual os tribunaes se pronunciariam, enfraquecendo assim a lei e a autoridade encarregada de executal-a." ${ }^{235}$ Segundo Leopoldo de Bulhões, argumentando contra o protecionismo:

O systema consagrado no regulamento vigente permittio que algumas companhias extrangeiras voltassem a funcionar no paiz e continuar suas operações. Esse facto, ao contrário dos que pensam os adeptos de um nativismo prejudicial aos paizes novos e aos próprios interesses commerciais, vem corroborar a confiança nos poderes públicos. ${ }^{236}$

E a respeito da importância da concorrência entre as companhias:

Só a concorrência pode alentar o commercio de seguros e a confiança que taes contatos exigem, não a obtem as associações pela circumstancia da nacionalidade a que pertençam, mas por um systema de garantias que faça realçar a probidade de suas administrações, a realidade do capital e a segurança de suas transacções.

Em 1904, constatou-se insuficiência de pessoal para o trabalho na inspetoria de seguros. Foi proposta então a criação de subinspetorias, criadas para funcionarem nos Estados, de modo que as tarefas pudessem ser divididas entre a União e os governos estaduais. $^{237}$

No Relatório do Ministério da Fazenda de 1906, afirma o Ministro David Campista ser necessário ampla dedicação do governo para permitir o bom funcionamento da Inspetoria de Seguros, cujo descuido institucional e paralisação dos trabalhos acarretariam "graves prejuízos, não só ao governo como, em maiores proporções, às

\footnotetext{
${ }^{234}$ BRASIL, Relatório do Ministério da Fazenda, 1903, p. 109

235 BRASIL, Relatório do Ministério da Fazenda, 1903, p. 109

${ }^{236}$ Ibidem, p. 111

${ }^{237}$ BRASIL, Relatório do Ministério da Fazenda, 1904, p. 596
} 
classes conservadoras do paiz." ${ }^{238}$ Devido ao mau funcionamento do órgão, o Ministério da Fazenda permitiu a contratação de "colaboradores extranumerários" que, após contratados, permitiram que "os serviços fossem postos em dia com maxima regularidade”. Nas palavras do próprio Ministro:

Não se tem o Governo se descurado deste importante ramos de atividade publica, que em todos os paizes cultos tem merecido os zelos de uma organização meticulosa e que agora mesmo na França vem de constituir a mais importante secção de um duodesimo Ministerio.

A despeito do referido cuidado do governo para com o órgão, David Campista cita embaraços e resistências por parte das companhias de seguros, nacionais e estrangeiras, no que diz respeito aos serviços de fiscalização levados adiante pela Inspetoria Estatal. Segundo o Ministro, o relatório anual do chefe da repartição fazia referência a dificuldades em se realizar uma fiscalização "completa, energica e efficaz":

Estamos em verdadeiro período de experiencia e ensaio, de hesitação e apalpadelas, depois de havermos conseguido ver promulgada sobre o assumpto uma lei quasi perfeita e que consignava os aquisitos e reformas dos paizes mais adeantados, - onde o serviço de fiscalização passou por lenta e laboriosa gestação. 239

A importância de um corpo legislativo eficiente e capaz de exercer funções de fiscalização já era algo notado e destacado pelo Ministério da Fazenda brasileiro naquele ano de 1906. A expectativa de se implantar no Brasil uma legislação inspirada pelos "paizes mais adeantados" sugere o reconhecimento, sobretudo por parte do setor público, acerca da necessidade de um sistema de regras e regulações que poderiam condicionar a atuação do setor privado. Uma legislação eficiente e capaz de regular o setor de seguros constituir-se-ia como uma instituição nacional, cuja atuação estimularia um adequado ambiente às trocas e ao desenvolvimento econômico.

Com o passar dos anos, é possível visualizar o resultado da queda do Regulamento Murtinho e da implementação da nova legislação que regulasse o setor; a partir de 1903, aos poucos as companhias de seguros estrangeiras voltaram a operar no Brasil. O número, no entanto, nunca mais voltou a ser como antes da legislação de Murtinho. No ano de

${ }^{238}$ BRASIL, Relatório do Ministério da Fazenda, 1906, p. 52

${ }^{239}$ BRASIL, Relatório do Ministério da Fazenda, 1906, p. 52 (destaque meu). 
1908 haviam 53 seguradoras funcionando no país, das quais 41 eram nacionais e 12 estrangeiras. A respeito do funcionamento das companhias de seguros marítimos no país, apresentamos os seguintes dados para o ano de 1908:

TABELA 8 - Capital emitido e prêmios recebidos: companhias de seguros marítimos estrangeiras e nacionais, 1910 (valores em mil réis)

\begin{tabular}{|l|l|l|l|}
\hline & Prêmios recebidos & $\begin{array}{l}\text { Capital total } \\
\text { emitido }\end{array}$ & $\begin{array}{l}\text { Pagamentos de } \\
\text { dividendos }\end{array}$ \\
\hline $\begin{array}{l}\text { Companhias } \\
\text { nacionais }\end{array}$ & 12.500 .000 .000 & 17.200 .000 .000 & 1.400 .000 .000 \\
\hline $\begin{array}{l}\text { Companhias } \\
\text { estrangeiras }\end{array}$ & 3.300 .000 .000 & 528.000 .000 & \\
\hline
\end{tabular}

Fonte: BRASIL, Relatório do Ministério da Fazenda, 1910, p. 318

A partir dos dados apresentados, temos que em 1908 a maior parte das companhias de seguros marítimos funcionando no Brasil, mesmo após a revogação do Regulamento Murtinho, eram nacionais.

No que diz respeito às companhias de seguros de vida, à época temos um total de 8 companhias funcionando no Brasil, 7 nacionais e uma estrangeira. A única firma internacional do setor era a New York Life Insurance Company 
TABELA 9 - Capital emitido e prêmios recebidos: companhias de seguros de vida estrangeiras e nacionais, 1910 (valores em mil réis)

\begin{tabular}{|l|l|l|l|l|}
\hline & $\begin{array}{l}\text { Valores totais } \\
\text { em contratos }\end{array}$ & Reservas totais & $\begin{array}{l}\text { Prêmios } \\
\text { recebidos }\end{array}$ & Sinistros pagos \\
\hline $\begin{array}{l}\text { Companhias } \\
\text { nacionais }\end{array}$ & 69.197 .200 .000 & 41.700 .000 .000 & 15.000 .000 .000 & 4.700 .000 .000 \\
\hline $\begin{array}{l}\text { Companhias } \\
\text { estrangeiras }\end{array}$ & 2.800 .000 & 1.800 .000 .000 & 1.900 .000 .000 & 163.000 .000 \\
\hline
\end{tabular}

Fonte: BRASIL, Relatório do Ministério da Fazenda, 1910, p. 318

Podemos concluir que a despeito do Apesar do Regulamento Murtinho ter sido alterado e esvaziado em 1903, em momentos posteriores podemos notar a preocupação com o desenvolvimento de companhias nacionais, como em longo texto publicado pelo jornal Correio Paulistano em maio de 1904, à época auto intitulado como "órgão do Partido Republicano". Este jornal publicava em suas páginas os casos bem-sucedidos de concessões de seguros de vida após o falecimento do segurado; a maioria dos casos são de maridos que morriam e deixavam algum montante às viúvas. Naquele mesmo mês temos que a Companhia Sul América realizou indenizações de Rs 50:000\$000 a uma viúva. ${ }^{240}$ Também em 1914 faleceu em São Paulo "o estimado corretor desta praça e conceituado capitalista", Alberto José Guignard, deixando à viúva Leonor Veiga Guignard o valor de Rs 200:000\$000, soma considerada bastante expressiva pelo jornal. ${ }^{241}$

O referido seguro deixado a Leonor Veiga Guignard despertou, durante todo o mês de maio de 1904, a atenção do jornal a respeito da importância dos seguros de vida em uma sociedade onde, pouco a pouco, "desaparecia a força da superstição". ${ }^{242}$ Segundo texto publicado no jornal pela companhia Sul América:

\footnotetext{
${ }^{240}$ BRASIL, Correio Paulistano, Arquivo do Estado de São Paulo, 01 de maio de 1904, p. 03.

${ }^{241}$ BRASIL, Correio Paulistano, Arquivo do Estado de São Paulo, 01 de maio de 1904, p. 01

${ }^{242}$ A respeito da superstição existente em torno da compra de seguros de vida, considerados portadores de mau agouro para o proprietário da apólice, conforme avançavam as décadas de 1890 e 1910 estes passaram a ser mais bem aceitos pela sociedade. Em 1889 um suicídio no Jardim Botânico chocou a sociedade carioca da época por ter se tratado de um rapaz jovem, membro da importante família Teixeira Leite; o ocorrido foi associado ao fato de que a vida do rapaz esta segurada pela New Yotk Life Insurance Company. BRASIL, The Rio News. Rio de Janeiro: A. J. Lamoureux ,16 de dezembro de 1889, p. 6.
} 
O seguro de vida tornou-se hoje uma imposição da previdência, e cada vez mais alarga-se mais a sua esphera de acção em toda a parte do mundo. Todos os factores de resistencia foram pouco a pouco desapparecendo, apesar de repousarem primitivamente numa das forças mais invencíveis da natureza humana, a força da superstição; e hoje o seguro de vida entra triuphalmente, como um indispensável apparelho, nos habitos de toda a sociedade. Não temos sinão louvores para os progressos que elle tem feito no Brasil. Evidentemente podia ser muito maior o seu desenvolvimento: mas, si compararmos a marcha ascendente que ele tem tido neste ultimo deccenio, verificar-se-á que nos sobram motivos de contentamento. Uma causa principalmente, tem concorrido para isso, e é a seriedade provada das nossas companhias: de facto, raras tem sido as questões sobre pagamento dos sinistros, e em regra a liquidação é feita com a maior presteza e a maior solicitude. ${ }^{243}$

Há também uma reflexão acerca do papel das companhias de seguros como instituições capazes de substituir o Estado no que diz respeito à formação de caixas de previdência:

Não há dúvida que as companhias de seguros estão destinadas a substituir o Estado nas pensões e montes-pios. Não se trata de uma questão a discutir, porque é um caso resolvido: não haveria orçamento capaz de supportar a progressão das despesas com a chamada classe dos inactivos. O que se vai dar, mesmo nos países onde permaneceram as pensões e os montes pios, é a adaptação dessas instituições de seguro, entrando como factores indispensaveis a edade, as prestações, a capitalização, as reservas. De resto se isso não quer ceder, será uma simples ilusão para o Estado e ainda pior para os contribuintes: a catastrophe final é inevitável. ${ }^{244}$

O mesmo texto, mais adiante, faz uma comparação com as circunstâncias dos EUA e de países europeus, que segundo o Correio Paulistano possuíam ampla tradição em seguros de vida e faziam-no nas mais variadas situações:

Devíamos ir pensando um pouco neste problema, aliás já tão bem estudado entre nós. E quanto ao seguro de vida, que hoje é feito nos EUA e na Europa até em pequenas viagens em caminhos de ferro, até para pequenos acidentes de trabalho,

${ }^{243}$ BRASIL, Correio Paulistano, Arquivo do Estado de São Paulo, 26 de março de 1904, p. 02.

${ }^{244}$ Ibidem, p. 02 
toda a propaganda é pouca para generalisal-o, tanto são os benefícios que delle resultam..$^{245}$

Mas o que realmente nos interessa é mostrar a posição da Companhia Sul América e do Correio Paulistano no que diz respeito à monopolização dos serviços realizada por companhias estrangeiras em anos anteriores, antes da promulgação das leis que favoreceram o setor nacional, em 1901:

Isto era tanto mais necessario, quanto as companhias extrangeiras, por assim dizer, monopolizavam esse serviço. Era insdispensavel que a inatacável correcção dessas companhias não tivesse soluções de continuidade ao momento em que a lei brasileira favorecia a organização de companhias nacionaes; e felizmente assim tem sido, mesmo tratando-se de avultadas sommas, como a de 200:000\$000 paga a semana passada pelo seguro de vida a que nos referimos. ${ }^{246}$

A Sul América vangloriava-se nos jornais por realizar sorteios semestrais e gratuitos de apólices de seguros de vida; em fevereiro de 1905 organizou um grande evento em sua sede no Rio de Janeiro, sorteando 45 títulos no Brasil, Chile e na Argentina. Segundo texto publicado no Correio Paulistano:

Eleva-se a Rs 8:000\$000 aproximadamente a somma paga pela Sul América às viúvas e orphams de seus segurados fallecidos, sem que uma só vez fosse necessaria a intervenção judicial para a liquidação dos seguros. A única família onde os chefes de família devem confiar o futuro dos que lhe são caros é a Sul América. ${ }^{247}$

A filantropia por meio de sorteios era fundamental para o lucro e bom funcionamento de muitas companhias, pois a concessão dos seguros de vida gratuitos pressupunha a compra anterior de alguma outra apólice e estimulava a permanência na instituição. Os trechos transcritos chamam atenção, no entanto, pela alusão à valores burgueses pouco condizentes com a estrutura política e econômica do Brasil de então, como preocupação com o futuro, poupança e sacrifício, todos conceitos recém introduzidos em uma sociedade cujas heranças escravistas e coloniais faziam-se bastante

\footnotetext{
${ }^{245}$ BRASIL, Correio Paulistano, Arquivo do Estado de São Paulo, 26 de março de 1904, p. 02.

${ }^{246}$ Ibidem, p. 02

${ }^{247}$ BRASIL, Correio Paulistano, Arquivo Público do Estado de São Paulo, 22 de fevereiro de 1905, p. 03.
} 
visíveis. Os referidos sorteios, no entanto, foram suspensos em dezembro do ano de 1906.248

Citaremos outro exemplo de resistência para com as companhias de seguros estrangeiras. As notícias nos diários semanais, além de trazerem à tona os casos de fraudes de companhias de seguros e segurados, também faziam registros públicos de casos bemsucedidos. O Correio Paulistano cedia espaço em suas páginas para que sociedades ou pessoas físicas elogiassem supostos rápidos pagamentos de sinistros e casos de eficiência das seguradoras.

Em 12 de janeiro de 1905, o Correio transcreveu carta publicada alguns dias antes no Jornal do Comércio, de autoria do advogado Heitor Peixoto, na qual elogiava a maneira como a Companhia Minerva agiu quando o Grande Hotel dos Estados, localizado na cidade do Rio de Janeiro, sofreu grave incêndio. Segundo o advogado "não foram precisos nenhum esforço nem o menor dispendio de argumentos ou empenhos para que aquella respeitavel companhia se promptificasse à satisfação do damno sofrido." A afirmação nos leva a concluir que muitas companhias dificultavam o acesso dos clientes às indenizações nos momentos de ocorrência de sinistros.

A apólice detida pelo hotel era do valor de Rs 25:000\$000, não muito alta se a compararmos com valores de apólices contrafogo de residências e lojas, de maneira geral em torno dos Rs 100:000\$000 (muitas vezes divididos entre mais de uma companhia). ${ }^{249}$ Ao final de sua carta, acrescenta o advogado:

Acredito que rendo apenas uma homenagem de justiça tornando conhecida liquidação, maximé tratando-se de uma companhia nacional, para as quaes os poderes publicos nem sempre tem olhado com as mesmas attenções que, não raro, procuram dispensar às estrangeiras.

Conforme desenvolvia-se a estrutura financeira nacional, ampliavam-se as possiblidades de inserção das companhias de seguros, cujas apólices vendidas refletiam os investimentos levados adiante no Brasil. Como dito acima, a legislação desse setor respondia de maneira bastante direta às mudanças econômicas sofridas pelo país, e até o

\footnotetext{
${ }^{248}$ BRASIL, Correio Paulistano, Arquivo Público do Estado de São Paulo, 14 de dezembro de 1906, p. 02.

${ }^{249}$ BRASIL, Correio Paulistano, Arquivo Público do Estado de São Paulo, 12 de janeiro de 1905, p. 03. Estabelecimentos comerciais podiam ter seu seguro em mais de uma sociedade, como o caso do comerciante paulista Cyrinco Ferraz, cujo estabelecimento era seguro nas companhias Mercurio, Minerva e Lloyd. BRASIL, Correio Paulistano, Arquivo Público do Estado de São Paulo, 14 de maio de 1905, p.02.
} 
ano de 1914 não ocorreram novas mudanças no corpo de leis regulador do setor. Podemos considerar que os avanços, disputas e conflitos em torno da formulação de um corpo de leis capaz de coordenar o funcionamento do mercado de seguros no Brasil diziam respeito à construção dos laços capitalistas locais. A partir dos dados referentes ao ano de 1908, contatamos que no início do século $\mathrm{XX}$ um setor de seguros propriamente nacional desenvolvia-se com relativo vigor no Brasil, bastante influenciado pela legislação restritiva às atividades das companhias estrangeiras promulgada por Joaquim Murtinho em 1901.

\section{$\underline{2.2-O \text { Encilhamento }}$}

Talvez o boom financeiro que marcou as economias fluminense e paulista no início da década de 1890, o famoso Encilhamento, possa ser considerado um marco de diferenciação da política econômica do Império e da República. Por mais que as raízes do referido boom, bem como da subsequente crise que o acompanhou, possam ser identificadas já nos estertores do Império, sob o Ministério do Visconde de Ouro Preto, toda a euforia do Encilhamento refletiu o estado de espírito experimentado pelo país após anos sob uma legislação financeira bastante restritiva. ${ }^{250}$ Sabemos que durante o Império reconheceu-se a inadequação da concessão de crédito baseada em relações familiares e pessoais; também formaram-se instituições de financiamento desprovidas desses laços e foram impostas contínuas restrições à atuação de bancos, companhias de seguros e sociedades anônimas, impondo obstáculos à iniciativa privada local.

O período do Império, portanto, foi marcado pela tensão entre o potencial de crescimento econômico proporcionado pelo café e as limitações ao setor financeiro impostas pelo governo. Essa tensão explodiu logo após a proclamação da República, quando a política econômica do novo regime se preocupou em livrar o país das amarras da época do Império; as contradições e conflitos desse processo podem ser ilustrados de maneira emblemática pela crise do Encilhamento, a ser apresentada adiante.

Em uma breve análise a respeito das forças políticas que constituíam a base de apoio à proclamação da República, constata-se que logo nos primeiros meses do novo

\footnotetext{
${ }^{250}$ HANLEY, Anne, Native Capital: financial institutions and economic development in São Paulo, Brazil, 1850-1920. Stanford: Stanford University Press, 2005, p. 85. Como exemplo de legislação restritiva da época do Império citamos a Lei 1.083 de 1860, conhecida como "Lei dos Entraves", que reduziu a emissão de papel moeda e vales pelos bancos privados e impôs maior controle sobre a abertura e organização de Sociedades Anônimas.
} 
governo a classe dominante passou a discordar entre si e entrou em disputa no que diz respeito às decisões fundamentais no âmbito da política monetária e cambial.

De fato, a relação por vezes conflituosa entre o Estado e as frações de classe hegemônicas pode ter como consequência disputas acerca da política econômica a ser adotada. $^{251}$ A constituição interna das referidas classes altas passou à época por um relativo processo de fracionamento, cujas razões explicam-se em grande parte devido à diversificação e complexificação das suas atividades produtivas. Nas palavras de Emília Viotti da Costa:

As forças que momentaneamente se tinham unido em torno das ideias republicanas entraram em choque. Os representantes do setor progressista da lavoura, fazendeiros de café das áreas mais dinâmicas e produtivas, elementos ligados à incipiente indústria, representantes das profissões liberais e militares, nem sempre tinham as mesmas aspirações e interesses. As divergências que os dividiam repercutiam em conflitos no Parlamento e eclodiam em movimentos sediciosos que polarizavam momentaneamente todos os descontentamentos, reunindo desde monarquistas até republicanos insatisfeitos. $^{252}$

Para autores como Winston Fritsch e Renato Perissinoto, a análise política e econômica da primeira República brasileira não deveria perpassar por explicações que atribuam aos interesses cafeeiros todo o controle da máquina estatal da época; tampouco seria razoável enxergar o Estado como uma instituição plenamente autônoma e alijada dos interesses exportadores. O ideal seria identificar uma relação estreita entre esses interesses e o Estado, levando em conta, no entanto, a existência de motivações propriamente estatais na formulação de políticas econômicas. ${ }^{253}$

A complexidade das relações entre Estado e capital cafeeiro teria, para ambos os autores, seu exemplo mais expressivo no Funding Loan de 1898 e nas políticas restritivas de Campos Sales, cujos desdobramentos permitiram a entrada do Brasil no padrão ouro;

\footnotetext{
${ }^{251}$ PERISSINOTTO, Renato, Estado e capital cafeeiro em São Paulo (1889-1930). São Paulo: Annablume/FAPESP, 2000.

${ }^{252}$ VIOTTI DA COSTA, Emília, Da Monarquia à República: momentos decisivos. São Paulo: UNESP, 1999 , p. 395.

${ }^{253}$ PERISSINOTO, Renato, obra citada, p. 36 e 72. FRITSCH, Winston. “Apogeu e crise na Primeira República: 1900-1930”. Marcelo de Paiva Abreu (org.). A ordem do progresso. Dois séculos de política econômica no Brasil. Rio de Janeiro. Editora Elsevier, 2014, p. 35.
} 
tais medidas definitivamente não se coadunavam com as expectativas dos exportadores de café, sempre apoiadores do câmbio baixo. ${ }^{254}$

As novas forças políticas em questão apareceram e adquiriram importância no decorrer do Império. Suas atividades relacionavam-se diretamente ao núcleo agrícola fundamental da economia brasileira, porém refletiam a expansão e diversificação econômica pela qual o país vivia: eram comerciantes ligados ao comércio de importação e exportação, trabalhadores livres, industriais, banqueiros, além de uma classe média urbana em ascensão formada por profissionais liberais e oficiais do exército. Em meio a esse contexto de diversificação, as companhias de seguros encontraram mais opções de inserção econômica.

A entrada do capital estrangeiro a partir da década de 1860 fez com que, à época da proclamação da República, já se tivesse formado um interesse da elite do Rio de Janeiro e de São Paulo em se associar às firmas estrangeiras, tornando-se sócia minoritária nos empreendimentos do capital forâneo e participando, mesmo que de forma relativamente subordinada, do processo de expansão do capitalismo no Brasil.

Dentre as referidas fricções no seio da classe dominante, citaremos aquela que talvez tenha se tornado a mais evidente e mais tratada pela literatura econômica: a disputa no que diz respeito ao câmbio. A importância do debate em torno da cotação da moeda e a amplitude de sua baixa a partir do chamado Encilhamento, no ano de 1891, serão tratados a seguir.

Ao assumir como Ministro da Fazenda no governo provisório de Deodoro da Fonseca, Rui Barbosa levou adiante a política econômica expansionista do último gabinete do Império, aprofundando-a em certos aspectos. Em 17 de janeiro de 1890 foi promulgado o Decreto 165, que previa a organização de bancos de emissão espalhados pelas regiões Norte, Centro e Sul do país, cada qual com capitais de, respectivamente, Rs 150.000:000\$000, Rs 200.000:000\$000 e Rs 100.000:000\$000. ${ }^{255}$ A tentativa de espalhar o meio circulante pelo país fazia-se urgente, dado que $80 \%$ dos depósitos bancários estavam concentrados no Rio de Janeiro. ${ }^{256}$

\footnotetext{
${ }^{254}$ FRITSCH, Winston. “Apogeu e crise na Primeira República: 1900-1930”. Marcelo de Paiva Abreu (org.). A ordem do progresso. Dois séculos de política econômica no Brasil. Rio de Janeiro. Editora Elsevier, 2014, p. 35

${ }^{255}$ BRASIL, Coleção de Leis do Brasil. 1890, Vol. I, p. 94.

${ }^{256}$ FRANCO, Gustavo. "A primeira década republicana". em Marcelo de Paiva Abreu (org.). A ordem do progresso. Dois séculos de política econômica no Brasil. Rio de Janeiro. Editora Campus, 1995, p. 17.
} 
O lastro das emissões poderia ser feito na forma de títulos da dívida pública; segundo Rui Barbosa, as reservas metálicas não deveriam ser utilizadas para a conversibilidade e sim para monetizar o grande território nacional, remunerar a mão de obra livre e constituir o capital fixo e circulante do país. Para o primeiro Ministro da Fazenda republicano, a manutenção do padrão ouro servia apenas para deixar entesourados os metais necessários à modernização do país.

Segundo Celso Furtado, a proclamação da República e a abolição da escravidão significaram o início do desequilíbrio da balança de pagamentos brasileira, que ao longo do Império havia sido praticamente inexistente, ou pelo menos pouco preocupante. Para o autor, a economia escravista desestimulava o consumo local e restringia a necessidade de importações, o que tornava o volume de exportações igual ou maior que a demanda por moeda. ${ }^{257} \mathrm{O}$ nível de consumo desprezível tornava baixo o volume de bens importados, e a balança superavitária permitia que o país vivesse em confortável situação fiscal.

Em contraposição a essa visão, temos a análise de William Summerhill, cujo enfoque, no entanto, não está na balança comercial e nem no consumo de bens importados em uma economia escravista, e sim na conta de capitais. Para o autor, o século XIX imperial foi sim marcado por contínuas crises fiscais, já que desde o primeiro empréstimo britânico em 1824 até a proclamação da República, o Brasil teria acumulado uma dívida externa de 30 milhões de libras esterlinas. Em 1889, cerca de dois terços desse valor foi refinanciado e o prazo do pagamento foi ampliado por mais cinquenta e seis anos. Além disso, nesse mesmo período a dívida interna tornara-se ainda maior, superando os valores da dívida estrangeira e atingindo a soma de 50 milhões de libras esterlinas. ${ }^{258}$

A preocupação com a monetarização nacional, no entanto, não impediu o governo republicano de diminuir a concessão de crédito aos proprietários agrícolas decadentes. Tentava-se "opor um dique à onda impetuosa e avolumada de empréstimos à lavoura, sistema lesivo, assim para o Tesouro como para o trabalho nacional." ${ }^{259}$ Buscou-se fazêlo reduzindo contratos de empréstimos num total de Rs 39.000:000\$000, valor a ser poupado pela União. Nas palavras de Rui Barbosa, a suspensão dos "falsos auxílios à

\footnotetext{
${ }^{257}$ FURTADO, Celso, obra citada, 1959, p. 190.

258 SUMMERHILL, William, obra citada, p. 03.

${ }^{259}$ BRASIL, Relatório Ministério da Fazenda, 1893, p. 25.
} 
lavoura" permitiu a poupança de uma despesa correspondente à quarta parte de todo o orçamento anual. ${ }^{260}$

Apesar das restrições como a redução dos empréstimos à agricultura, a política econômica republicana iniciou-se, como dito acima, de forma bastante expansionista, sob forte aceleração das emissões e desvalorização cambial. As tentativas de estímulo do crédito levadas adiante pelo Visconde de Ouro Preto não comprometeram a paridade da moeda, que no final do Império estava valorizada e valia 27d/mil réis. Em 1892, durante a crise do Encilhamento, a moeda chegara a 12 d/mil réis e em 1898, a 5 d/mil réis.

Referindo-se ao período em questão, Serzedelo Correia, Ministro da Fazenda durante o governo de Floriano Peixoto, afirmou: "o câmbio, termômetro infalível do malestar geral, anunciava a elevação da temperatura, precursora da tormenta." ${ }^{261}$ De fato, a conjuntura era de crise. A desvalorização cambial, a imensa massa de papel moeda inconversível e a trajetória explosiva da inflação levaram à inúmeras falências. Mesmo instituições relativamente sólidas não puderam resistir à queda do valor dos títulos, que abarrotavam em quantidade a bolsa de valores do Rio de Janeiro.

Em seu Relatório como Ministro da Fazenda referente ao ano de 1892, Rodrigues Alves tratou da ampliação do gasto público e das emissões não lastreadas durante o ministério Rui Barbosa. Este último, quando senador entre os anos de 1890 e 1892, teria dito que "os governos revolucionários não podem ser econômicos" 262 , e o grande déficit deixado pelo governo provisório havia sido inevitável. Nas palavras de Rodrigues Alves:

O exercício de 1890, o da sua gestão [Rui Barbosa], não seria, provavelmente, liquidado com déficit inferior a Rs 62.000:000 $\$ 000$, porque, como era bem de prever, as rendas publicas não puderam acompanhar a progressão ascendente das despezas extraordinárias, obrigadas pelas reformas em quase todos os serviços, em tempos completamente anormaes, e de condescendencias e transacções. ${ }^{263}$

A justificativa dos gastos públicos excessivos serem decorrência de um período excepcional, de consolidação de um novo regime político, esteve presente no discurso dos políticos de então. Segundo Felisbello Firmo de Oliveira Freire, Ministro da Fazenda entre abril de 1893 e agosto de 1894:

\footnotetext{
${ }^{260}$ BRASIL, Relatório Ministério da Fazenda, 1893, p. 31.

${ }^{261}$ BRASIL, Relatório Ministério da Fazenda, 1892, p. 69.

${ }^{262}$ BRASIL, Relatório do Ministério da Fazenda, 1892, Introdução, p. 03.

${ }^{263}$ BRASIL, Relatório do Ministério da Fazenda, 1892, Introdução, p. 03.
} 
O equilíbrio orçamentário, que deve ser preoccupação constante de todo o governo sensato, não é uma utopia entre nós. Mas, desde que não logramos chegar a uma justa equação entre a receita e a despesa durante quase meio seculo de paz e florescimento, na phrase dos preconisadores do passado regimen, depois das agitações sanguinolentas, que precederam constitucionalismo imperial, como esperal-o já da República, ainda no seu período de organização, tão conturbado por elementos de uma conspiração latente e pertinaz, cegamente coadjuvada por espíritos que esquecem o dever jurado de servir e defender as instituições $(. . .)^{264}$

Os erros e excessos da política econômica doméstica, no entanto, faziam parte de um contexto mais amplo, a saber, a entrada dos países periféricos nos circuitos financeiros internacionais. As tensões não diziam respeito apenas às articulações internas, e cada vez mais as moratórias e calotes desencadeavam crises de pagamento, liquidações e falências de instituições de diferentes países. No ano de 1890 e no mesmo contexto do Encilhamento, assistiu-se à crise bastante semelhante na Argentina, quando uma forte queda dos preços do trigo desestabilizou a balança de pagamentos e impossibilitou o país de pagar seus credores estrangeiros, dentre eles o banco britânico Baring Brothers. O banco quebrou, tendo sido socorrido por uma capitalização dos Rothschilds; estes últimos também realizaram empréstimos de emergência à Argentina, cuja política econômica, a partir de então, deveria obedecer a regras claras de saneamento econômico.

Após a quebra do Baring Brohers, os títulos sul americanos por algum tempo deixaram de ser confiáveis ou desejáveis pelos ingleses, e perderam valor em Londres; a crise, no entanto, não foi capaz de afetar a economia em níveis mundiais. ${ }^{265}$

A situação era bastante parecida no Brasil. A condição de credores permitiu aos Rothschilds se manifestarem no que dizia respeito à política monetária e cambial brasileira. Suas constatações foram publicadas no Relatório do Ministério da Fazenda de 1891:

(...) a baixa do câmbio e a depressão dos stocks brasileiros denotam mui seria crise financeira, devida principalmente ao temor de novas emissões de papel

\footnotetext{
${ }^{264}$ BRASIL, Relatório do Ministério da Fazenda, 1893, p. 04.

${ }^{265}$ SUMMERHILL, William, obra citada, p. 225. De acordo com o autor: Brazil was not alone in starting the 1890s in a weaker position in external credit markets. The de cade had an inauspicious beginning for Latin American sovereign borrowers in general. There is evidence that the Argentine debt crisis of 1890 led to a reappraisal of default risk in London for the region as a whole.
} 
moeda, que seriam consideradas muitissimo prejudiciais ao credito do Brazil e a todo o paiz. ${ }^{266}$

Ou ainda, a respeito do câmbio, afirmaram:

(...) a sua baixa deveria ser atribuída primeiramente, mas só em pequena parte, às dificuldades do transporte de café e outros produtos do interior e respectivo embarque, mas a razão principal é o grande aumento que tem tido nos últimos tempos a emissão de papel moeda no Brazil; e não só os recentes acontecimentos no sul da América, mas também a história de semelhantes factos no passado, mostram quão perigosa e futil é uma tal politica financeira para augmentar o crédito ou beneficar por qualquer forma as finanças de vosso paíz. ${ }^{267}$

Sabe-se que a presença dos bancos estrangeiros no Brasil, cuja vinda remete à década de 1860, alterou o funcionamento da concessão de crédito no país. A nova dinâmica no mercado financeiro deu-se sobretudo a partir dos primeiros bancos ingleses, que substituíram os comissários e as Casas Bancárias no financiamento da cafeicultura no Vale do Paraíba fluminense. A concorrência com as instituições estrangeiras e sobretudo os efeitos restritivos da Lei dos Entraves de 1860 provocaram sucessivas falências das Casas Bancária nacionais, sendo o caso da Casa Souto e Cia., a maior do país, um dos mais conhecidos. ${ }^{268}$ Os canais de financiamento sofreriam então a polarização entre o Banco do Brasil e os bancos estrangeiros; estes últimos saíram fortalecidos pelas quebras das instituições locais.

Apesar da identificação de gargalos estruturais que geravam inflação, os credores referiam-se sobretudo à emissão inconversível como principal culpada pela desvalorização da moeda; a identificação com crises semelhantes no contexto latino americano era bastante evidente pela referência aos "acontecimentos no sul da América".

As medidas para recuperação da economia iniciaram-se a partir de tentativas de valorização do câmbio. Serzedelo Correia, Ministro da Fazenda sob o governo de Floriano Peixoto e defensor de estímulos à indústria nacional, propôs a retirada de moeda em circulação já em dezembro de 1890. Em Decreto de 17 de dezembro de 1890, o Ministro propunha a retirada do equivalente a Rs 160.000:000\$000 em papel moeda, a

\footnotetext{
${ }^{266}$ BRASIL, Relatório do Ministério da Fazenda, 1891, p. 24

${ }^{267}$ BRASIL, Relatório do Ministério da Fazenda, 1891, p. 24

${ }^{268}$ TANNURI, Luiz Antonio, obra citada, p. 24 e 25.
} 
fim de valorizá-lo. ${ }^{269}$ A lei foi elogiada pelos Rothschilds, que enviaram telegrama no qual afirmavam que a aplicação das referidas medidas "conduzirão à prosperidade do Brazil e à manutenção de seu crédito no exterior." ${ }^{270}$ Apesar das referidas tentativas de saneamento e controle da emissão de moeda, a efetiva valorização cambial só seria alcançada no final da década de 1890, sob o Ministério de Joaquim Murtinho.

No que diz respeito à atuação dos Rothschilds no Brasil dessa época, sabemos que durante os empréstimos concedidos nos anos de 1893 e 1895 os banqueiros europeus não exigiram a implementação de medidas econômicas ortodoxas como contrapartida. Durante toda a década de 1890, a necessidade do novo regime republicano de emitir moeda foi bastante alta, sobretudo se considerarmos os conflitos políticos pelos quais o Brasil de então atravessava, dentre eles a Revolução Federalista e a Guerra de Canudos. Levando em conta as duas guerras civis brasileiras e com medo de passar por uma situação de bancarrota, os Rothschilds optaram por não pressionar o país a sanar suas contas em meio a um contexto politicamente instável. ${ }^{271}$

As exigências quanto à adoção de política fiscal e monetária mais austeras por parte dos Rothschilds vieram apenas a partir de 1898, com o Funding Loan, quando o governo republicano não mais lidava com as pressões das guerras civis e vivia uma profunda crise da dívida, sob constante eminência de tornar-se insolvente. Seguindo as exigências dos Rothschilds, a atuação de Joaquim Murtinho no Ministério da Fazenda entre 1898 e 1902 elevou o valor da moeda e estabilizou a inflação, sob o custo político de desagradar cafeicultores interessados na desvalorização cambial e na competição do café no mercado externo. Em contrapartida à rigidez das medidas ortodoxas implementadas, o Brasil teve suas possibilidades de crédito no exterior expandidas e foi bem-sucedido na aquisição de futuros empréstimos, como no ano de 1901, quando a administração Campos Sales tomou emprestado 17 milhões de libras esterlinas para investir em estradas de ferro. ${ }^{272}$

Após um curto período de domínio dos militares, a República brasileira consolidou-se em torno das oligarquias cafeicultoras, cujos governos firmavam-se sobre a base da riqueza cafeeira e das exportações. O governo do paulista Prudente de Morais

\footnotetext{
${ }^{269}$ BRASIL, Relatório do Ministério da Fazenda, 1892, p. 73

${ }^{270}$ Ibidem, P. 73

${ }^{271}$ WELLER, Leonardo, « Rothschilds' 'Delicate and Difficult Task': Reputation, Political Instability, and the Brazilian Rescue Loans of the 1890s ». Entreprise \& Society : Cambridge University Press, maio de 2015, p. 26.

${ }^{272}$ WELLER, Leonardo, obra citada, p. 25 e 26. 
iniciou-se em 1894 e foi sucedido em 1898 por outro político de São Paulo, Campos Salles, famoso pela implementação da conhecida "política dos governadores". Após o fracasso de se construir um partido de elites em nível nacional (vide a tentativa malsucedida de hegemonia por parte do Partido Republicano Federal), a política dos governadores colocava-se como uma alternativa de organização das oligarquias locais no plano federal. ${ }^{273}$ De fato, temos que os fazendeiros cafeicultores, base de apoio da monarquia, rapidamente aderiram aos moldes republicanos e passaram a sustentar o novo regime.

Os primeiros anos de presidência civil foram marcados pela descentralização política e pela ascensão das oligarquias locais, que passam aos poucos a dominar e conduzir os assuntos regionais de suas províncias, em forte contraponto à centralização dos tempos do Império; em troca à essa relativa autonomia, as elites provinciais concediam o apoio necessário à esfera federal. O novo arranjo político fez-se mais visível sobretudo a partir da entrada em vigor da Constituição federalista de 1891. ${ }^{274}$

Como exemplo das propostas federalistas da primeira Constituição republicana, citamos a descriminação da renda da União da dos Estados, além de especificação dos impostos que seriam arrecadados pelo nível federal e pelo provincial. Segundo o texto, à medida que os Estados fossem se organizando nos moldes do novo pacto federalista, caberia ao governo central abrir créditos especiais que liquidassem seus serviços e pagamentos. ${ }^{275}$ Podemos a partir daí concluir que a formação dos orçamentos dos Estados já era uma preocupação à época da entrada em vigor da Constituição de 1891.

As oscilações do câmbio no final do século XIX e início do XX estão estreitamente associadas ao principal produto de exportação do Brasil à época: nos momentos de alta do preço do café, assistiu-se majoritariamente à adoção de políticas econômicas restritivas e de câmbio valorizado; nas baixas, seguia-se política econômica expansionista e, na busca pela compensação dos maus preços, estimulava-se a exportação via desvalorização da moeda. ${ }^{276}$

\footnotetext{
${ }^{273}$ CARDOSO, Fernando Henrique. "Dos governos militares a Prudente-Campos Sales", em FAUSTO, Boris. História Geral da Civilização Brasileira. Tomo III, vol. 2. Rio de Janeiro: Bertrand Brasil, 2006, p. 49.

${ }^{274}$ VIOTTI DA COSTA, Emília, obra citada, p. 397.

275 BRASIL, Relatório do Ministério da Fazenda, 1892, p. 05.

${ }^{276}$ NETTO, Antônio Delfim, O problema do café no Brasil. São Paulo: Editora UNESP, 2009, p. 26. Segundo o autor, os movimentos da taxa cambial são determinantes para que se amorteça a queda dos preços no mercado externo. A respeito da corrosão do preço da força de trabalho, fruto da inflação e das desvalorizações cambiais, cita-se Celso Furtado, Formação Econômica do Brasil. Rio de Janeiro: Editora Fundo de Cultura: 1959.
} 
Esse procedimento resultava em uma transferência de renda dos setores que pagavam as importações para aqueles que vendiam as exportações, na conhecida "socialização das perdas" apresentada por Celso Furtado. ${ }^{277}$ Sabemos que o denominado "grande capital cafeeiro", devido à diversificação das suas atividades para além do núcleo agrícola, não necessariamente sofria com momentos de câmbio baixo, ao contrário da parcela de fazendeiros estreitamente ligados à produção e exportação dos grãos, o chamado "pequeno e médio capital cafeeiro". 278

Optar por seguir o padrão ouro em determinados momentos e em outros não era decisão cara à política econômica inglesa, que em épocas de crise ou de más colheitas suspendia o lastro metálico de suas emissões. ${ }^{279}$ Verificamos semelhante situação no Brasil do final do século XIX.

Deve-se levar em conta, no entanto, que apesar da famosa afirmação de Eugenio Gudin ("café é câmbio") a cotação da moeda no Brasil de então não era determinada apenas pela sazonalidade dos grãos e sim subordinada a outras múltiplas variáveis, dentre elas o preço de outros produtos básicos no mercado externo (cita-se como exemplo a borracha, que conheceu forte boom produtivo entre 1902 e 1906, no governo de Rodrigues Alves) e o nível do fluxo de capital estrangeiro. ${ }^{280}$

Para melhor compreendermos as disputas em torno do valor da moeda e da política econômica do início da República, cabe retornarmos à análise a respeito da classe dominante e as mudanças pela qual passou no período em questão. Como dito acima, a partir da segunda metade do século XIX observa-se significativa transformação da burguesia cafeeira, sobretudo paulista, cujas atividades aos poucos ultrapassam as plantações e passam a incluir operações comerciais e até mesmo o financiamento de outros fazendeiros. Os grandes proprietários se afastaram da supervisão direta das plantações e se engajaram na política, bem como na participação acionária de ferrovias, como no caso da Companhia Paulista de Estradas de Ferro, da Sorocabana e da

\footnotetext{
${ }^{277}$ FURTADO, Celso, obra citada, 1959, p. 106.

${ }^{278}$ SAES, Flávio Azevedo, A grande empresa de serviço público na economia cafeeira (1850-1930). São Paulo: Hucitec, 1986, p. 139

${ }^{279}$ MARX, Karl, O Capital, livro III, Tomo I, p. 308.

${ }^{280}$ A respeito da relação estreita entre café e câmbio, cita-se Celso Furtado, obra citada, p. 194. Sobre a viabilidade da submissão do câmbio ao café e a análise de outras variáveis, ver Maria Teresa Versiani, "Café e câmbio no Brasil (1890-1906)", in Pesquisa e Planejamento Econômico, 15, dez. 1985. Para a relação entre o nível do câmbio e os fluxos de capital estrangeiro: Pedro Paulo Zaluth Bastos, A dependência em progresso: fragilidade financeira, vulnerabilidade comercial e crises cambiais no Brasil (1890-1954). Campinas: UNICAMP. IE, p. 96.
} 
Mogiana. ${ }^{281}$ Estiveram igualmente envolvidos no setor bancário, tendo participado ativamente da formação dos primeiros bancos paulistas; segundo Flávio Saes, estes últimos constituíram-se baseados mais na expansão da produção cafeeira do que a partir de uma política monetária expansionista. ${ }^{282}$

Constatamos, portanto, uma ampliação das funções do capital cafeeiro, que se diversifica e passa a ser constituído por diferentes frentes: era formado pelo capital agrário, industrial, bancário e comercial. ${ }^{283}$ A partir dessa ampliação dos investimentos, os membros do capital cafeeiro não poderiam mais "enfurnar-se nas longínquas fazendas do interior paulista." ${ }^{284}$ Ferrovias, bancos, casas importadoras e exportadoras exigiam a presença da elite nos centros urbanos em expansão, e o grande capital cafeeiro detinha a maior parte das concessões dos serviços públicos; ademais, tal presença permitia melhores possibilidades de contato e pressão sobre as decisões do governo a respeito da política econômica a ser adotada. Pode-se afirmar que expansão do grande capital cafeeiro não se fez sem antes gerar fortes oposições no seio da classe dominante. ${ }^{285}$

Esse processo de diferenciação interna da classe proprietária e a ampliação de suas atividades para além do núcleo agrícola acabou por criar diferentes expectativas, dentro da elite paulista e fluminense, no que diz respeito ao câmbio. Sabemos que o período conhecido como Encilhamento, cujas origens remontam ao gabinete Ouro Preto ainda no Império e teve seu auge sob o Ministério de Rui Barbosa, foi marcado por excessiva emissão de títulos não lastreados em riqueza real, além de uma intensa desvalorização do câmbio. Para além das repercussões diretas do Encilhamento na economia brasileira da época, a desvalorização da moeda constituía-se como mecanismo de defesa de parte do

\footnotetext{
${ }^{281}$ SAES, Flávio, As ferrovias de São Paulo, 1870-1940. São Paulo: Hucitec, 1981, p. 190. Citamos o caso do Barão de Tietê, presidente da seguradora União Paulista de Seguro e um dos principais acionistas da Estrada de Ferro Mogiana.SAES, Flavio, A grande empresa de serviços públicos na economia cafeeira, 1850-1930, p. 46.

282 SAES, Flávio, Crédito e bancos no desenvolvimento da economia paulista (1850-1950). São Paulo: Instituto de Pesquisas Econômicas, 1986, p. 81.

${ }^{283}$ SILVA, Sérgio, Expansão cafeeira e origens da indústria no Brasil. São Paulo: Alfa-ômega, 1976, p. 60. Para o autor, dentre as referidas diferenciações internas à burguesia cafeeira, a atividade comercial destacou-se sobre as outras; seria possível, portanto, considerar o capital cafeeiro brasileiro do final do século XIX como predominantemente comercial. Essa dominância do comércio seria resultado do fraco desenvolvimento das relações de produção capitalistas no país. Nas suas palavras: "Em outros termos, a acumulação capitalista realiza-se sobretudo ao nível do comércio, o que acarreta um desenvolvimento mais lento das forças produtivas."

${ }^{284}$ PERISSINOTTO, Renato, obra citada, p. 66.

${ }^{285}$ SAES, Flávio Azevedo, A grande empresa de serviço público na economia cafeeira (1850-1930). São Paulo: Hucitec, 1986, p. 139 e p. 155. Afirma o autor: “(...) a identidade de interesses entre o grande capital e os médios fazendeiros, possível até certo momento, desfez-se nos anos noventa."
} 
núcleo agrícola da classe dominante, que aos poucos entrou em choque com as expectativas de outros grupos sociais.

Para os comerciantes ligados ao comércio estrangeiro, as melhores possibilidades de importação advinham do câmbio valorizado. Já o capital industrial em formação poderia se beneficiar da desvalorização monetária para exportar bens de consumo leves, mas por outro lado era prejudicado quando precisava importar máquinas e equipamentos. O capital estrangeiro, cada vez mais presente na economia nacional, posicionava-se favorável ao câmbio alto a fim de evitar a corrosão dos seus rendimentos quando os remetesse às respectivas sedes. As instituições financeiras cujo funcionamento baseavase na formação de poupanças, como os bancos e as companhias de seguros, também tendiam a apoiar a valorização da moeda e o cumprimento do padrão ouro, para que seus fundos não fossem comprometidos e reduzidos pela inflação. ${ }^{286}$

Apesar das companhias de seguros terem expressiva representação na totalidade do capital estrangeiro aportado no Brasil (como dito anteriormente, entre 1886-1896 as estrangeiras representavam cerca de $30,7 \%)^{287}$, o número total das seguradoras instaladas ou organizadas no país era relativamente pequeno; entre 1890 e 1896 apenas 16 novas instituições passaram a funcionar. ${ }^{288}$ No período compreendido entre 1808 e 1864 podese constatar situação parecida pois, apesar de numericamente pouco relevantes (formavam apenas 3,1\% do total das empresas de então), correspondiam à expressiva quantia de $23,1 \%$ do capital das sociedades formadas. ${ }^{289}$

A menor participação das seguradoras na economia brasileira em termos numéricos (mas não no que se refere aos aportes de capital) levou alguns autores a afirmarem que a bolha financeira do início da República, conhecida como Encilhamento, não teria influenciado diretamente as companhias de seguros no que diz respeito à abertura de novas casas. ${ }^{290}$ Por mais que as seguradoras não tenham sido tão afetadas pelo Encilhamento como de fato o foram outras instituições financeiras, consideraremos que

\footnotetext{
${ }^{286}$ Segundo Celso Furtado, a enorme expansão do crédito após as reformas do Governo Provisório em 1889 e a criação dos bancos emissores regionais levou à uma maior depreciação cambial, que corroeu a capacidade de compra das classes médias e resultou em intranquilidade social. A pressão se fez presente sobretudo nos setores urbanos, demostrando que a partir de então o interesse diretamente ligado à exportação teria que lidar com outros grupos, para os quais a desvalorização da moeda não era positiva. FURTADO, Celso, obra citada, 1959, p. 203.

${ }^{287}$ CASTRO, Ana Célia, obra citada, p.61.

${ }^{288}$ ABREU, Marcelo de Paiva e FERNANDES, Felipe T. "The insurance industry in Brazil: a long-term view”. Working paper 10-109, Harvard Business School, 2010, p. 07.

${ }^{289}$ SAES, Alexandre \& GAMBI, Thiago, "A formação das companhias de seguro na economia brasileira (1808-1864)". História Econômica e História de Empresas. XII. 2, 2009, p. 01.

${ }^{290}$ ABREU, Marcelo de Paiva e FERNANDES, Felipe T., obra citada, p. 07.
} 
a euforia especulativa envolveu as companhias de seguro de maneira indireta. Como trataremos mais à frente, a crise financeira estimulou significativas mudanças na legislação que determinava o funcionamento das instituições de crédito e de companhias de seguro, tornando as regras de ambas mais duras e inflexíveis.

No ano de 1889, apenas uma nova companhia de seguro foi criada no Brasil: a Companhia de Seguros de Vida Argos Beneficente, com um capital de Rs 300:000\$000, expressivo se o compararmos com o capital da Companhia de Navegação Esperança Marítima, de Rs 120:000\$000, e ao da Companhia Brazileira de Commercio e Industria, de Rs 200:000\$000, mas inferior ao Banco Agrícola do Brazil, com capital de 10,000:000\$000 ou ao Banco Intermediário do Rio de Janeiro, de 1,000:000\$000, todos também abertos em $1889 .{ }^{291}$

Segundo os dados de Maria Bárbara Levy, em 1891, ano em que as economias fluminense e paulista ainda sofriam os efeitos do Encilhamento, o Rio de Janeiro possuía em sua praça o expressivo número de 72 companhias de seguros cotadas na Bolsa de Valores com capital realizado num total de Rs 57.000:000.

TABELA 10 - Companhias cotadas na Bolsa do Rio de Janeiro, 1891

\begin{tabular}{|l|l|l|l|}
\hline $\begin{array}{l}\text { Setor de } \\
\text { atividade }\end{array}$ & Quantidade & $\begin{array}{l}\text { Capital } \\
\text { realizado (em } \\
\text { mil contos) }\end{array}$ & $\begin{array}{l}\text { Distribuição do } \\
\text { capital (\%) }\end{array}$ \\
\hline $\begin{array}{l}\text { Bancos e } \\
\text { casas } \\
\text { bancárias }\end{array}$ & 231 & 1712 & 35,6 \\
\hline $\begin{array}{l}\text { Estradas de } \\
\text { ferro }\end{array}$ & 117 & 944 & 19,6 \\
\hline $\begin{array}{l}\text { Serviços } \\
\text { públicos }\end{array}$ & 72 & 534 & 11,1 \\
\hline Agropecuária & 80 & 247 & 5,1 \\
\hline
\end{tabular}

${ }^{291}$ BRASIL, Retrospecto do Jornal do Commercio. Rio de Janeiro: Typographia do Jornal do Commercio de Rodrigues, 1889, p. 128. 


\begin{tabular}{|l|l|l|l|}
\hline $\begin{array}{l}\text { Construção } \\
\text { civil }\end{array}$ & 29 & 130 & 2,7 \\
\hline Navegação & 57 & 106 & 2,2 \\
\hline Colonização & 16 & 87 & 1,8 \\
\hline Comércio & 33 & 86 & 1,8 \\
\hline Mecânica & 12 & 60 & 1,2 \\
\hline Seguros & 72 & 57 & 1,2 \\
\hline $\begin{array}{l}\text { Fiação e } \\
\text { tecidos }\end{array}$ & 36 & 48 & 1,0 \\
\hline Mineração & 20 & 47 & 1,0 \\
\hline $\begin{array}{l}\text { Alimentos e } \\
\text { bebidas }\end{array}$ & 61 & 45 & 0,9 \\
\hline $\begin{array}{l}\text { Material de } \\
\text { construção }\end{array}$ & 35 & 44 & 0,9 \\
\hline Açúcar & 46 & 32 & 0,4 \\
\hline Café & 8 & 22 & 0,5 \\
\hline Couros & 7 & 557 & 11,6 \\
\hline $\begin{array}{l}\text { Vestuário e } \\
\text { armarinho }\end{array}$ & 43 & $\mathbf{4 8 1 5}$ & 0,7 \\
\hline $\begin{array}{l}\text { Outros e não } \\
\text { identificados }\end{array}$ & 364 & $\mathbf{3 3}$ & \\
\hline TOTAL & & & \\
\hline
\end{tabular}

Fonte: Levy, M. B. A indústria do Rio de Janeiro através de suas sociedades anônimas. Rio de Janeiro: Editora UFRJ, 1994, p. 131.

Como constatamos através dos dados da tabela, em 1891 havia mais companhias de seguros do que de navegação em funcionamento no Brasil, apesar do capital realizado na Bolsa de Valores destas últimas ser maior. Em 1889, no entanto, temos que as companhias de seguros estavam dentre as sociedades de capital aberto mais capitalizadas, perdendo apenas para bancos e ferrovias. Logo após as seguradoras vinham as companhias de navegação, as têxteis, e em último lugar os engenhos centrais de açúcar. ${ }^{292}$

292 CAVAlCANTI, A. O Meio Circulante Nacional, 1808-1831. Brasília, Editora Universidade de Brasília, 1983 (publicado originalmente em 1893) p. 355. Apud SCHULZ, John, obra citada, p. 79. 
De fato, o início da década de 1890 já estava marcado pela consolidação do número de companhias de seguros no Brasil, e o número de firmas nacionais mostravase maior que o de estrangeiras. Aos poucos a concorrência era uma variável com a qual as seguradoras tinham cada vez mais que lidar; segundo o Relatório da diretoria da Companhia de Seguros Marítimos e Terrestres Indemnisadora, publicado no Diário Oficial em fevereiro de 1893, o lucro líquido de Rs 47:239\$155 referente ao ano de 1892 da sociedade havia sido bastante razoável, "não obstante as grandes difficuldades com que se luta para obter seguros na presente época; pois não desconheceis o accrescido número de companhias congeneres que existem nessa praça, esforçando-se em fazer concurrencia umas às outras." 293

A mesma companhia Indemnisadora referia-se a problemas nos seus balanços no ano de 1892, quando o contexto de crise brasileiro provocou interrupções de pagamentos em cadeia e afetou diversas instituições financeiras devedoras entre si. Em março daquele ano o Banco Industrial e Mercantil do Rio de Janeiro encontrava-se em terrível situação e suspendeu o pagamento a seus credores, impossibilitando que todos os depósitos em seus cofres fossem resgatados; a situação afetou a seguradora, que possuía cerca de Rs 8:462\$300 depositados no Banco. ${ }^{294}$ A Companhia Indemnisadora continuou a financiar o Estado brasileiro durante o período do Encilhamento. Em seu balanço de 31 de dezembro de 1892 temos que seu ativo possui Rs 155:757\$959, isto é, 7,3\% do ativo total, provenientes de amortização e juros de 150 apólices da dívida pública federal. ${ }^{295}$

Sabemos que após a independência e durante o processo de formação do Estado Nacional, observou-se a consolidação do serviço da dívida pública brasileira; entre 1827 e 1889, o valor total devido a credores internos aumentou na proporção de 108 vezes. ${ }^{296}$ O crescente endividamento possui clara relação com a conjuntura do setor agrícola. Desde os estertores do Império, quando as crises na lavoura cafeeira do Vale do Paraíba fluminense comprometiam a renda dos fazendeiros e minavam a base de apoio do regime, o último Primeiro Ministro da monarquia, Visconde de Ouro Preto, engajou-se em tentativas de reformas com o propósito de retomar a base de suporte do governo. $\mathrm{O}$ programa de reformas, proposto pelo último gabinete de Ministros para salvar o Império, acabou por não ser bem-sucedido, e as mudanças não foram aplicadas a tempo. ${ }^{297} \mathrm{O}$

\footnotetext{
${ }^{293}$ BRASIL, Diário Oficial da União, 19 de fevereiro de 1893, p. 843,

${ }^{294}$ Ibidem, p. 846.

${ }^{295}$ Ibidem, p. 847.

${ }^{296}$ BRASIL, Relatório Ministério da Fazenda, 1889-1890, p. 114.

${ }^{297}$ PRADO JR., Evolução Política do Brasil e outros estudos. São Paulo: Brasiliense, 1963, p. 94.
} 
desprestígio das instituições monarquistas permaneceu; o Senado Vitalício e o Conselho de Estado tornaram-se exemplos de estruturas políticas anacrônicas que freavam o progresso do país. Foi sob tal conjuntura que o Império "agonizou". ${ }^{298}$

No que diz respeito à maior necessidade de crédito, esta era bastante notada pelos governos desde o último gabinete do Império. Em novembro de 1888, Ouro Preto propôs uma Lei Bancária que alteraria as disposições da Lei do Entraves de 1860, permitindo o retorno da pluralidade bancária e do aumento de emissões. As companhias que se propusessem a realizar operações bancárias poderiam emitir bilhetes ao portador e à vista, possíveis de serem convertidos em moeda. A emissão, no entanto, só seria permitida desde que fosse depositado na Caixa de Amortização o valor equivalente ao emitido e na forma de apólices da dívida pública interna. ${ }^{299}$ De fato, as referidas mudanças, bem como o retorno à paridade de $27 \mathrm{~d}$./mil réis, puderam ser levadas à cabo por Ouro Preto devido ao aumento da exportação de café, à maior entrada do capital estrangeiro e ao avanço da circulação monetária característicos dos últimos anos da monarquia

A Lei Bancária de 1888 também estabelecia que os bancos só poderiam emitir até 2/3 do seu capital realizado, ou no máximo 20 mil contos de réis. Era previsto que as companhias e instituições financeiras dessem preferência aos empréstimos para a lavoura, sempre num prazo máximo de três anos. ${ }^{300}$ É bastante claro que o objetivo da medida era ampliar a liquidez e consequentemente a capacidade de remuneração da mão de obra livre, permitindo a consolidação de um mercado de trabalho nacional, inexistente nos anos de escravidão. A lei inspirava-se nos moldes do Crédit Mobiliér francês; formado em 1852 na França pelos irmãos Pereire e o sob o governo de Luis Bonaparte, a referida sociedade foi, ao lado do Crédit Foncier, uma das primeiras a mobilizar as economias da classe média francesa e utilizá-las em amplos empreendimentos estrangeiros, como construção de estradas de ferro, minas, navios transatlânticos, fornecimento de serviços urbanos como água e luz, além de participação em companhias de seguros. ${ }^{301}$

\footnotetext{
${ }^{298}$ VIOTTI DA COSTA, Emília, obra citada, p. 426.

${ }^{299}$ O Decreto 3.403, de 24 de novembro de 1888, foi regulamentado pelo Decreto 10.144 , de 05 de janeiro de 1889. BRASIL, Coleção de Leis do Império do Brasil, 1888, Vol. 01, p. 78.

300 TANNURI, Luiz Antonio, obra citada, p. 44.

${ }^{301}$ Reproduzimos aqui trecho do periódico The Rio News a respeito dos perigos da expansão do crédit foncier na América do Sul: "Há agora uma epidemia atormentado este país e as Repúblicas do Rio da Prata (...) - a criação de bancos crédit foncier para distribuição de empréstimos desnecessários a uma classe improvidente. Não é uma questão de incentivar ou ajudar a agricultura, mas, antes, um objetivo de estender a assistência a especuladores indignos e homens que estão procurando levar a cabo grandes empreendimentos com capital emprestado. Não é intenção ajudar os pequenos agricultores, para os quais sabemos que tais empréstimos têm sido negados pelos bancos, mas para fornecer capital barato a políticos
} 
A reação esperada pelo governo, apesar dos esforços, não veio. Os banqueiros incomodaram-se com a limitação de valor e prazo dos empréstimos, e não ampliaram a concessão de crédito. O insucesso da Lei Bancária de 1888 levou o governo a lançar mão do que seria a cartada final, isto é, a concessão de crédito por parte do Tesouro Nacional. Em 06 de julho de 1889 foi promulgado o Decreto 10.262, conhecido como Auxílio à Lavoura. A partir de então os bancos nacionais contariam com um repasse de Rs 87.500:000\$000 do Tesouro para que realizassem empréstimos diretos aos proprietários agrícolas. O limite a ser emprestado poderia ser de até o dobro dessa quantia, os juros seriam de $6 \%$ ao ano e os prazos eram muito maiores do que aqueles propostos pela Lei Bancária de 1888; o empréstimo direto do Tesouro aos bancos poderia ser pago entre sete e vinte e dois anos, e o crédito dos bancos aos clientes variava entre um e quinze anos. ${ }^{302}$ No início da República, o Tesouro era credor de grande parte dos bancos. ${ }^{303}$

A ampla disponibilidade de recursos repassada pelo governo ao setor financeiro gerou expectativas quanto à recuperação e a solvência da lavoura cafeeira fluminense, bem como à dinamização de outras áreas da economia. De fato, após os repasses, notouse o aumento da capitalização de diversas instituições; a representação do capital das companhias de seguros na Bolsa de Valores do Rio de Janeiro à época, por exemplo, era de Rs 35.700:000\$000, menor apenas que a dos bancos (Rs 572.000:000\$000) e ferrovias (Rs 176.000:000\$000), mas maior que companhias de navegação (Rs 26.000:000\$000), fábricas têxteis (Rs 25.000:000\$000) e engenhos de açúcar (Rs 9.000:000\$000). Chama atenção o fato da Bolsa de Valores fluminense ser dominada por bancos e empresas de serviços. A pouca participação do capital industrial, no entanto, era uma condição também para o mercado de ações britânico desse mesmo período. ${ }^{304}$

2.3. As companhias de seguros e as possibilidades de crédito urbano, imobiliário e $\underline{\text { hipotecário }}$

À época do Encilhamento e da crise da lavoura cafeeira fluminense, as possibilidades de financiamento eram escassas. A colocação de títulos privados no mercado brasileiro era uma novidade com relativa dificuldade de aceitação, e hipotecas e debêntures levavam tempo para se consolidarem. Além de pouco interesse do público na

\footnotetext{
que vivem nas cidades e gastam mais do que suas propriedades podem produzir [...]." BRASIL, The Rio News. Rio de Janeiro: A. J. Lamoureux, 8 de julho de 1889, apud SCHULZ, obra citada, p. 160.

302 TANNURI, Luiz Antonio, obra citada, p. 61.

${ }^{303}$ BRASIL, Relatório Ministério da Fazenda, 1892, p. 68.

${ }^{304}$ SCHULZ, A crise financeira da abolição. São Paulo: Edusp, 2013, p. 79.
} 
compra de papéis privados, os empréstimos realizados por esse setor ainda eram pouco desenvolvidos, o que levava à preferência pelo crédito público. Na maior parte das vezes esses empréstimos possuíam datas de vencimento menores que os do setor público (em geral cerca de dois anos), sofriam menos os impactos da inflação, e tinham como garantia propriedades de terra e escravos. ${ }^{305}$ Essas características marcaram a economia brasileira durante todo o Império e durante as primeiras décadas republicanas.

Os bancos de crédito real, cujo principal objetivo era o de servir à lavoura, não foram bem-sucedidos e acabaram por deixar de funcionar; o Banco de Crédito Popular, criado sob o ministério de Rui Barbosa em 1890 e transformado em Banco Hipotecário em 1893, não teve grande sucesso. Segundo o Relatório do Ministério da Fazenda de 1912, não era possível aos bancos hipotecários exercerem suas funções por ser o Brasil um país pobre, sem economias e sem possibilidades de absorver uma ampla emissão de letras hipotecárias. Estas últimas não eram capazes de competir com os títulos da dívida do governo, oferecidos ao público com praticamente as mesmas vantagens das letras hipotecárias e com maiores garantias. O pequeno capital disponível, fruto da diminuta poupança nacional, optava pelos títulos mais garantidos e conservadores; é nesse contexto que a instituição da hipoteca não pôde salvar a lavoura decadente de café do Vale do Paraíba fluminense. ${ }^{306}$

Muito foi discutido nesse período a respeito de novos mecanismos de crédito à lavoura. As operações hipotecárias eram tidas como inviáveis, dentre outros motivos, devido à precipitação da abolição do trabalho escravo; os credores sabiam que em pouco tempo a produção agrícola sofreria mudanças estruturais em relação ao valor da terra e à remuneração da mão de obra, e a eminência do fim da escravidão tornava os empréstimos com garantia na propriedade fundiária cada vez mais escassos. Segundo Maria Bárbara Levy, o governo tentou atrair o capital estrangeiro ao ramo, propondo a venda de letras hipotecárias com garantia de juros de $5 \%$ e amortização o prazo de 30 anos. O interesse pelos títulos, no entanto, mostrou-se fraco; o capital forâneo percebeu a velocidade com

\footnotetext{
305 SUMMERHILL, William, obra citada, p. 03.

${ }^{306}$ BRASIL, Relatório do Ministério da Fazenda, 1913 (I), p. 9. Desde o final do século XIX e no início do XX a produção de café se complexifica e passa a contar com o investimento de grandes somas de capital em máquinas importadas; a necessidade do crédito à lavoura faz-se cada vez mais evidente. Em 1909 os fazendeiros poderiam gastar até 6:500\$000 em uma máquina para separação dos grãos de café. BRASIL, Correio Paulistano, 8 de agosto de 1909, p. 08.
} 
que a propriedade rural brasileira se desvalorizava diante da perspectiva do fim da escravidão. ${ }^{307}$

Já em meio à crise do Império e no estertor do regime monarquista brasileiro, João de Sinimbú, senador por Alagoas, presidente do Banco Nacional entre 1875 a 1878 e presidente do Conselho de Ministros, afirmou em sessão junto à Câmara, em janeiro de 1879:

[a propriedade agrícola] era justamente o ponto vulneravel do systema. Nossa propriedade está atravessando uma época de transição delicada, perigosa mesmo, posso dizel-o. O trabalho servil tem de acabar, e logo seremos obrigados a substituil-o pelo trabalho livre. ${ }^{308}$

O governo republicano provisório, no entanto, apostou na hipoteca como forma de empréstimo, e a respeito do medo sobre a viabilidade da garantia hipotecária, afirmou Rui Barbosa:

Taes interrogações explicam-se nos que imaginam que a organização geral do crédito hipotechario pode cogitar em viver apenas da propriedade existente, dos valores já consolidados e immobilizados hoje na terra, na agricultura, na edificação urbana. Mas a grande funcção do credito hipotechario não é subsistir do que achou feito: é crear a propriedade hypothecavel.

Elle extrahe de si, por assim dizer, os seus elementos de vida. Transforma os baldios em campos cobertos de mésses, a poder dos recursos que offerece ao trabalho, cujos fructos o virão remunerar. ${ }^{309}$

Durante o Encilhamento, muitos industriais e empresários faliram por carência de capital circulante. Após a euforia e o excesso de emissões, o retraimento do numerário levou diversas instituições à ruína, e muitos bancos engajaram-se nas primeiras concessões de crédito hipotecário; de acordo com o Relatório do Ministério da Fazenda de 1892, fizeram-nos inspirados sobretudo pelo modelo de crédito mobiliário e agrícola da França de Napoleão III, sempre mediante recebimento da primeira hipoteca e por meio de penhor mercantil. ${ }^{310}$

\footnotetext{
${ }^{307}$ LEVY, Maria Bárbara, História da Bolsa de Valores do Rio de Janeiro. Rio de Janeiro: IBMEC, 1977, p. 104.

${ }^{308}$ BRASIL, Relatório do Ministério da Fazenda, 1910/1911, p. 162.

${ }^{309}$ BRASIL, Relatório do Ministério da Fazenda, 1889, p. 183.

${ }^{310}$ BRASIL, Relatório do Ministério da Fazenda, 1892, p. 74
} 
O aprofundamento das hipotecas deu-se sobretudo a partir de novembro de 1890 , quando foi criado o Banco de Crédito Popular. A instituição foi organizada a partir do Banco Colonial do Brasil, tinha sede no Rio de Janeiro e caixas filiais em outros pontos do país. As operações se dividiam entre caixa de penhor nacional, crédito geral popular e empréstimos a operários e pequenos proprietários agrícolas; estes últimos davam como garantia aos empréstimos a antecipação de suas colheitas e safras futuras, mecanismo bastante comum e anterior à consolidação da hipoteca. Além disso, o Banco de Crédito Popular contava com carteira comercial e industrial e podia subscrever ações, incorporar companhias e emitir debêntures. Segundo Rui Barbosa, Ministro da Fazenda à época de sua criação:

Corresponde a creação desse estabelecimento a uma das mais imperiosas necessidades sociaes, preenchendo entre as nossas instituições bancarias lacuna deploravel, qual a que se traduz na ausencia de estabelecimentos de credito popular. ${ }^{311}$

Em março de 1893, o Banco de Crédito Popular do Brasil foi autorizado a se transformar em Banco Hipotecário, sob condição de reduzir seu capital e assumir a dívida da instituição anterior junto do Tesouro Nacional. O Banco passou então a ter duas carteiras - a de crédito popular e a hipotecária. ${ }^{312}$

Aos poucos a hipoteca, agrícola ou urbana, passava a compor as instituições financeiras brasileiras. Ao empregarem seus fundos na concessão dessa modalidade de crédito, as companhias de seguros ampliaram as fontes de financiamento e as possibilidades de concessão de garantias numa economia pouco monetizada e recémsaída da escravidão. Já no século XX, era comum a existência de estabelecimentos, fabris inclusive, que construíam suas sedes com base no crédito hipotecário, como no caso da Companhia Vidraria Santa Marina, fundada em 1895 pelo futuro prefeito de São Paulo Antonio da Silva Prado, em 1909 considerada a maior fabricante de garrafas da América do Sul. ${ }^{313}$

A fábrica detinha o monopólio do uso das modernas máquinas da marca, capazes de fabricar nove milhões de garrafas de cerveja por ano; possuía força motriz elétrica, matriz energética de origem recente no país; três grandes fornos pra fundição de vidros,

\footnotetext{
${ }^{311}$ BRASIL, Relatório do Ministério da Fazenda, 1889/1890, p. 105

312 BRASIL, Relatório do Ministério da Fazenda, 1910 e 1911, p. 108

313 BRASIL, Correio Paulistano, Arquivo Público do Estado de São Paulo, 14 de maio de 1909 , p. 05. 
quatro fornos para resfriamento gradativo dos produtos, três grandes chaminés para o serviço dos fornos, um laboratório químico, jazidas de areia para fabricação do vidro, e um serviço de viação férrea interno da fábrica com cerca de 3.000 metros de extensão e duas chaves para a São Paulo Railway. Toda a indústria e as instalações descritas serviam como garantia ao empréstimo de mil contos de réis, solicitado publicamente por meio da emissão de debêntures. ${ }^{314}$ Todo o estabelecimento era segurado pelas companhias London \& Lancashire Insurance Company e Royal Insurance Company; cabe chamarmos atenção ao fato de que a apólice de seguro era tida como ativo da fábrica e entrava como parte da garantia ao empréstimo via hipoteca. ${ }^{315}$

Observamos exatamente a mesma situação para o caso da Companhia de Fiação e Tecidos São Bento, formada em 1908 na cidade de São Paulo. Em maio de 1899 dois sócios comerciantes paulistas haviam comprado a fábrica de tecidos São Bento, situada em Jundiaí, de seu antigo proprietário, o Banco da República do Brasil, a fim de ampliar sua atuação. Desde seu início a companhia já contava com capital aberto na Bolsa de Valores no total de Rs 1.500:000\$000 divididos em 7.500 ações de Rs $200 \$ 000$ cada. $^{316}$

A emissão pública de empréstimo via debêntures teria como garantia hipotecária a fábrica da Companhia em Jundiaí, cujo terreno possuía 8 mil metros quadrados; na sua própria descrição realizada no Correio Paulistano do dia 20 de maio de 1909, a Companhia cita seus "quatrocentos teares e respectivas fiações magnificamente installados em vasto pavilhão, grande e perfeito motor a vapor com força de cerca de 600 H.P, três grandes caldeiras, condenzadores e economisadores, completa instalação de machinas de preparação com os mais aperfeiçoados apparelhos (...), e toda a grande installação elétrica que abrange todas as dependencias da fábrica." Assim como no caso da Companhia Vidraria Santa Marina, a garantia hipotecária do empréstimo solicitado pela São Bento incluía as apólices de seguros da fábrica, concedidos pelas companhias Commercial Union Assurance Company, Previdente, Companhia Paulista de Seguros e Guardian Insurance Company. ${ }^{317}$ No seu balanço para o ano de 1909, temos que a São Bento possuía apólices de seguros no valor de Rs 11:930\$150, praticamente o mesmo valor de seu caixa, de Rs 11:659\$170. ${ }^{318}$

\footnotetext{
${ }^{314}$ BRASIL, Correio Paulistano, Arquivo Público do Estado de São Paulo, 14 de maio de 1909, p. 05.

315 Ibidem, p. 05

${ }^{316}$ BRASIL, Correio Paulistano, Arquivo Público do Estado de São Paulo, 20 de maio de 1909, 07.

${ }^{317}$ BRASIL, Correio Paulistano, Arquivo Público do Estado de São Paulo, 20 de maio de 1909, p. 07.

318 SCHOMPRÉ, Émile Quoniam. La Bourse de São Paulo. Typographia Casa Garrauz. São Paulo, 1911, p. 201.
} 
Mais adiante, no ano de 1906, as possibilidades de crédito urbano e imobiliário foram ampliadas e uma série de sociedades de crédito a moradia foram fundadas. Já em 1906 surge a Companhia Construtora e de Crédito Popular, em forma de sociedade anônima e com o capital de Rs 500:000\$000; possuía agências em São Paulo, Campinas e Santos. A companhia foi das primeiras a se instalar em São Paulo com o objetivo de construir prédios para seus mutuários mediante prestações mensais e juros baixos. Sua seção construtora responsabilizava-se pelas construções, reformas e consertos de casas. No ano de 1910, a companhia construiu 115 moradias, gastando cerca de Rs 1.014:264\$000 (Rs 8.819\$000 despendidos para cada casa) e pôde distribuir dividendos de $8 \%$ aos seus acionistas. A ampla demanda por crédito imobiliário do Brasil de então permitiu que a sociedade prosperasse e elevasse seu capital, no ano de 1910, de Rs 2:000:000\$000 para Rs 5:000:000\$000. ${ }^{319}$

Ainda em 1910 foi fundada em São Paulo a Companhia Urbana Predial, proprietária de vastos terrenos no bairro da Água Branca. Os $2.000 .000 \mathrm{~m}^{2}$ de propriedade da companhia foram divididos em lotes de $700 \mathrm{~m}^{2}$ e os prédios construídos pela própria companhia foram descritos como "cercados por jardins, modernos, bonitos e confortáveis". Poderiam ser pagos via concessão de crédito: um décimo pago na ocasião de se tomar posse da casa e o restante a prazo, em pagamentos mensais de até 10 anos, cobrando a Companhia juros de $8 \%$ ao ano. ${ }^{320}$

Também em São Paulo na primeira década do século XX passa a funcionar a Companhia Mútua de Crédito Predial, organizada por mutualidade para conceder crédito imobiliário e seguros de vida. Logo as agências se espalharam para Santos, Campinas, Curitiba, Belo Horizonte, Porto Alegre, Pelotas, Rio de Janeiro, Niterói, Pernambuco e Bahia. A Predial aplicava seus capitais em construções de prédios, e seus mutuários poderiam tornar-se proprietários dos edifícios via pagamento de prestações mensais. Tinham a possibilidade de realizar seguros de vida de Rs 30:000\$000, os quais poderiam, junto das moradias, deixar como patrimônio a seus herdeiros. ${ }^{321}$

Citaremos ainda a Companhia Iniciadora Predial, sociedade mutuaria de construções fundada com o capital de Rs 1.350:000\$000, desde seu início organizada como sociedade aberta, com 6750 ações no valor nominativo de Rs $200 \$ 000$ cada.

\footnotetext{
${ }^{319}$ BRASIL, Impressões do Brazil no século XX. Lloyd's Greater Britain Publishing Company, Arquivo Municipal de Cubatão, 1913, p. 366.

${ }^{320}$ BRASIL, Impressões do Brazil no século XX. Lloyd's Greater Britain Publishing Company, Arquivo Municipal de Cubatão, 1913, p. 666

${ }^{321}$ Ibidem, p. 666 
Seu objetivo era construir edifícios nos valores de até Rs 25:000\$000 ou Rs $30.000 \$ 000$ e oferecer empréstimos aos mutuários para que comprassem apartamentos, sempre mediante juros de $10 \%$. Segundo a própria companhia, no início do século XX era possível comprar terrenos em boas condições de preço, de modo a construir sobrados populares e habitações simples, de um só pavimento, para que operários pudessem alugálas. O setor de crédito popular ia bem e em fins de 1910 foi possível à Iniciadora Predial distribuir dividendos de $8 \%{ }^{322}$ No início do século XX, o crédito imobiliário voltado para habitação das classes trabalhadoras já era uma realidade em São Paulo e no Rio de janeiro.

Por fim, cabe chamarmos atenção para outro caso, ocorrido cerca de vinte anos antes do anterior e em contexto bastante diverso, mas que nos apresenta novo exemplo do setor imobiliário expandindo sua atuação e concedendo seguros; é o caso do Banco de Funcionários Públicos do Rio de Janeiro, formado no contexto do Encilhamento. Apesar de constatarmos razoável número de empréstimos e financiamentos realizados por seguradoras, a existência de seguros concedidos por bancos era mais rara. ${ }^{323}$

O banco formou-se em setembro de 1890 no Rio de Janeiro, envolvido sobretudo no auxílio aos trabalhadores do governo, facilitando-lhes a compra de apartamentos, concedendo-lhes cartas de fiança para aluguel e fazendo adiantamentos financeiros; além disso, o banco possuía a curiosa função de proporcionar a compra de gêneros de primeira necessidade por preços inferiores aos do mercado. Constituído com o expressivo capital de Rs 2.000:000\$000, os empréstimos eram feitos mediante seguro de vida. Além dos juros de $8 \%$ ao ano sobre o capital devido, o banco também cobrava cotas de seguro de vida e seguro de fogo a serem pagas para uma terceira companhia, devidamente aceita pelos membros da sociedade. Apesar de não ser capaz de conceder diretamente seguros de vida e fogo, o banco previa, em seu estatuto, a construção de uma seção interna para tanto.

Foi apenas em fevereiro de 1900 que o Banco de Funcionários Públicos do Brasil passou a conceder seguros por conta própria e independentemente dos empréstimos realizados. A pré-condição para tanto era que seu capital atingisse o valor de Rs 2.000:000\$000; para a concessão de empréstimos para compra de prédios e apartamentos,

\footnotetext{
322 BRASIL, Impressões do Brazil no século XX. Lloyd's Greater Britain Publishing Company, Arquivo Municipal de Cubatão, 1913, p. 666

${ }^{323}$ Em maio de 1891, em meio ao desarranjo econômico do Encilhamento, o periódico The Rio News publicou que o conhecido Banco Vitalício, em funcionamento no Rio de Janeiro, "não era banco coisa nenhuma, e sim uma companhia de seguro tendo o Gen. Dr. Conselheiro Ruy Barbosa à sua frente." BRASIL, The Rio News. A. J. Lamoureux. Rio de Janeiro, 19 de maio de 1891, p. 05.
} 
o capital necessário era de Rs 1.000:000\$000. Em fevereiro de 1900, o banco possuía Rs 750:000\$000, e estes empréstimos e concessões de seguros não podiam, portanto, ser realizados. Mas desde então os funcionários públicos poderiam escolher as condições de alguns de seus empréstimos, determinando se obtinham crédito com seguro de vida, com garantia especial ou com amortização fixa; no primeiro caso, o seguro de vida seria concedido apenas mediante exame de sanidade realizado por médicos do próprio banco.

Com a nova condição do Banco de Funcionários Públicos, isto é, seu envolvimento direto na concessão de seguros, o ritmo e o valor de suas transações financeiras naturalmente aumentou. A ampliação do mercado de crédito para o mercado de seguros garantiu à instituição maior liberdade para contrair empréstimos em dinheiro, desde que com juros e amortizações pré-fixados, de modo que pudesse alargar suas transações. A experiência com a concessão direta de seguros, no entanto, durou pouco; já em abril de 1902 o banco fechou sua carteira de seguros de vida.

\subsection{Companhias de seguros e casas exportadoras}

As companhias de seguros e as casas exportadoras e importadoras possuíam uma relação bastante evidente desde o final do século XIX, sobretudo no estado de São Paulo, como veremos neste item. Sabemos que a inserção das firmas exportadoras na economia brasileira ampliava-se conforme perdia importância a figura do comissário; este último aos poucos tornava-se incapaz de lidar com o amplo crescimento do volume transportado desde a fazenda até o porto, e seus fretes não necessariamente eram menos custosos do que os das firmas exportadoras. Joaquim Nabuco já havia constatado que a concessão de crédito no segundo reinado fez do fazendeiro "o empregado agrícola que o comissário ou o acionista de banco tem no interior para fazer seu dinheiro render acima de 12\%". 324

De fato, a participação do comissário fez-se mais presente no Vale do Paraíba fluminense do que entre os fazendeiros paulistas. No primeiro caso, a descapitalização do proprietário agrícola devido ao pagamento de juros ao intermediário mercantil, que cobrava valores mais altos que os das casas exportadoras, foi bastante evidente. Aos poucos muitos fazendeiros construíram suas próprias casas comissárias como mecanismo de defesa da cobrança de juros. Segundo Maria Sylvia de Carvalho Franco, "(...) nem o fazendeiro podia desvencilhar-se facilmente de seu credor, a quem ficava cada vez mais

${ }^{324}$ FAORO, Raimundo, Os Donos do Poder. Porto Alegre: O Globo, 1979, p. 211. 
preso por dívidas que não chegava a saldar, nem podia deixar o comissário de acudir seu cliente." ${ }^{325}$

Em Santos, sede do comissariado paulista, a chegada das casas exportadoras e seu engajamento direto na concessão de crédito despertou a oposição dos comissários locais. A presença das casas estrangeiras alterou o padrão da comercialização do café, sobretudo a partir da década de 1890, quando passaram a comprar os estoques diretamente nas fazendas do interior e anularam a função intermediária dos comissários. ${ }^{326}$ A eliminação destes últimos, afastados do processo de comercialização dos grãos, também significou sua ausência dos circuitos financeiros. Os comissários, cujo crédito concedido não oferecia boas condições de prazo e era de curto prazo, passam a ter dificuldade de competir com as exportadoras, sobretudo as estrangeiras, que possuíam armazéns onde mantinham o café comprado dos fazendeiros e vendiam-no apenas quando estes demandassem. ${ }^{327}$ Além disso, a construção dos armazéns, garantidores da nova forma de comercialização do café, tinha seus juros garantidos pelo governo. ${ }^{328}$

O controle das casas exportadoras era bastante concentrado e não contou com expressiva participação do grande capital cafeeiro brasileiro. Era formado por um pequeno número de grandes firmas, alemãs, francesas e americanas, que dominavam o mercado exportador. Entre 1895 e 1906, 18,5\% de toda a exportação de café do porto de Santos foi realizada pela maior companhia de todas, a Theodor Willie \& Co., original de Hamburgo e com agências no Rio de Janeiro, Santos e em São Paulo desde 1855, e que além de café exportava borracha, peles, chifres e madeira. ${ }^{329}$ A referida casa exportadora esteve envolvida no setor de seguros, não os concedendo diretamente, mas tendo em seus estabelecimentos agentes que vendiam apólices de outras companhias, dentre elas a já citada The Royal Insurance Company, cujo capital em 1891 era de 2 milhões de libras

\footnotetext{
${ }^{325}$ FRANCO, Maria Sylvia de Carvalho, Homens livres na ordem escravocrata. São Paulo: Kairós, 1983, p. 168

${ }^{326}$ SAES, Flavio, A grande empresa de serviços públicos na economia cafeeira, (1850-1930). São Paulo: Editora Hucitec, 1985, p. 140.

${ }^{327}$ SAES, Flavio, Crédito e bancos no desenvolvimento da economia paulista (1850-1950). São Paulo: Instituto de Pesquisas Econômicas, 1986, p. 68. Segundo o autor, os comissários não tinham condições de oferecer crédito de longo prazo.

${ }^{328}$ SAES, Flavio, A grande empresa de serviços públicos na economia cafeeira, (1850-1930). São Paulo: Editora Hucitec, 1985, p. 140.

${ }^{329}$ HOLlOWAY, Thomas, Vida e Morte do Convênio de Taubaté. Rio de Janeiro: Paz e Terra, 1978, p. 51.
} 
esterlinas; eram também agentes de seguros marítimos da NordDeutsche Versicherungs Gesellschaft e agentes de seguros contra fogo da Northern Insurance Company Ltd. ${ }^{330}$

Outro exemplo era a Williams \& Cia., conhecida casa exportadora britânica estabelecida no Brasil em 1900. Seus principais produtos, exportados para o sul do Brasil e para toda a Europa, eram açúcar, algodão, caroço de algodão, borracha de mangabeira e milho. Os donos da firma eram agentes das companhias de navegação Mala Real Inglesa, Lamport \& Holt e Houston Line, e da Companhia de Seguros Northern Insurance \& Co., de Londres, além de diretores da usina de açúcar Conceição de Sinimbu, no Alagoas. ${ }^{331}$

Apesar do profundo estreitamento de seus laços financeiros, já salientado ao longo deste trabalho, o Brasil do período constituía-se fundamentalmente como uma economia agrário exportadora, cuja base de sustentação e arrecadação fazia-se sobretudo via exportação do café, daí o amplo interesse das companhias de seguros em se aliarem às principais casas exportadoras e garantirem a constante concessão de seguros marítimos para os estoques exportados. A exportação de café era, portanto, um grande negócio para as seguradoras, nacionais e estrangeiras, inseridas no mercado do Sudeste brasileiro.

Casas importadoras também tinham relação com as companhias de seguros; a tradicional Casa Baruel, firma paulista que importava remédios, especialidades farmacêuticas, artigos para indústria, perfumaria e instrumentos de cirurgia, era dirigida por Francisco Nicolau Baruel, também diretor do Banco de São Paulo e da Companhia Brasileira de Seguros. ${ }^{332}$

Dentre as casas de comércio mais importantes de São Paulo estava a Charles Hü \& Cia., fundada em 1893, importadora de vinhos, licores, conservas e gêneros alimentícios; era incorporadores da Companhia Franco Brasileira de Conservas Alimentícias e agentes da Companhia de Seguros Contrafogo L'Union e da Compagnie pour la Fabrication des Compteurs et Matériel d'Usines à Gas, ambas de Paris. ${ }^{333}$

Fora do eixo Rio de Janeiro e São Paulo existiam outros exemplos de estabelecimentos comerciais inseridos na área de seguros. Citamos a Kramer Leaens \& Cia., casa importadora e exportadora da cidade de Uruguaiana, no Rio Grande do Sul,

\footnotetext{
${ }^{330}$ BRASIL, Impressões do Brazil no século XX. Lloyd's Greater Britain Publishing Company, Arquivo Municipal de Cubatão, 1913, p. 577.

${ }^{331}$ Ibidem, p. 1057

332 BRASIL, Impressões do Brazil no século XX. Lloyd's Greater Britain Publishing Company, Arquivo Municipal de Cubatão, 1913, p. 710.

${ }^{333}$ Ibidem, p. 710
} 
fundada em 1896. Suas importações consistiam em secos e molhados recebidos da Europa e da América do Norte, farinha da Argentina, açúcar de Pernambuco e café do Rio de Janeiro; exportava sobretudo produtos regionais como couro e lã, sobretudo para Buenos Aires. Devido à inserção da casa no comércio nordestino, os sócios Bernardo Kramer, Firmino Leaens e Otto Ewe eram também agentes da Companhia de Seguros Aliança da Bahia. ${ }^{334}$

Em Ilhéus, na Bahia, foi fundada em 1911 a Ayre \& Cia. pelo britânico Charles Henry Bennet Ayre, ex executivo do London \& Brazilian Bank. A firma negociava como casa importadora de diversos artigos, mas também como cultivadora e compradora e cacau, sobretudo da firma F. Stevenson \& Co. Funcionavam também como agentes no distrito da Companhia de seguros Garantia da Amazônia. ${ }^{335}$

Em Manaus havia a casa comercial importadora W. Peters \& Cia, dos sócios alemães Cyril F. Kieman, W. Peters, sendo o segundo cônsul da Grécia em Manaus e diretor da Associação Comercial do Amazonas. Essa firma tornou-se conhecida por ser agente de várias firmas, nacionais ou estrangeiras, dentre elas companhias de seguros como a Garantia da Amazônia, Companhia de Seguros Marítimos Contrafogo Amazonense, e a Companhia Interesse Público. Além disso, exportavam em larga escala produtos como borracha, couro, castanhas e chifres e vendiam ferragens e artigos para seringueiros. ${ }^{336}$

A Companhia de Seguros Equitativa do Brasil, que entre 1907 e 1908 estampou uma polêmica pública com a Companhia Sul América a respeito da solvência dessa última, foi criada pelo advogado recifense Franklin Sampaio, proprietário da Companhia Internacional Comércio e Indústria e fundador do Banco do Estado do Rio de Janeiro e do Banco Construtor do Brasil. Era também presidente da sociedade anônima O Paiz e liquidador do Banco Rural e Hipotecário. ${ }^{337}$ A firma era representada na Paraíba pela casa comissária e importadora Militão Bivar, que também era representante de um altíssimo número de outros estabelecimentos, nacionais e estrangeiros. ${ }^{338}$

\footnotetext{
${ }^{334}$ BRASIL, Impressões do Brazil no século XX. Lloyd's Greater Britain Publishing Company, Arquivo Municipal de Cubatão, 1913

335 Ibidem, p. 889.

${ }^{336}$ BRASIL, Impressões do Brazil no século XX. Lloyd's Greater Britain Publishing Company, Arquivo Municipal de Cubatão, 1913, p. 998

${ }^{337}$ BRASIL, Impressões do Brazil no século XX. Lloyd's Greater Britain Publishing Company, Arquivo Municipal de Cubatão, 1913, p. 533

${ }^{338}$ Ibidem, p. 999
} 
No que diz respeito às possibilidades de armazenagem dos produtos agrícolas à época, era comum as casas exportadoras emitissem cupons denominados warrants, comprados pelos fazendeiros que pretendiam trocá-los por moeda quando o café fosse efetivamente vendido. Além disso, os warrants funcionavam como títulos de crédito, e os fazendeiros poderiam realizar pagamentos e obter empréstimos com seus cupons. $\mathrm{O}$ procedimento creditício era, portanto, mais complexo e sofisticado do que aquele levado adiante pelas casas comissárias, e por mais que os fazendeiros reclamassem da pressão baixista das casas exportadoras, que por vezes obrigavam-nos a vender a safra a preços não compensadores, passaram a obter a maior parte de seus empréstimos com estas últimas. ${ }^{339}$ Era a partir do armazenamento do café, realizado sobretudo por firmas estrangeiras, que os fazendeiros poderiam formar um estoque amortecedor, isto é, uma parcela da produção cafeeira capaz de ser inserida nos mercados internacionais nos momentos de alta excessiva do preço do produto. ${ }^{340}$

Conforme expandia-se a exportação cafeeira, sobretudo a partir da década de 1890, a armazenagem das sacas tornava-se aos poucos um ramo de investimento atraente para o capital estrangeiro. A Brazilian Warrant Company, registrada em Londres em 1909 com o capital de $£ 300.000$, absorveu as instalações de armazenagem e benefício, além de ter comprado firmas de corretores, fazendeiros e agências de navegação. ${ }^{341}$ Rapidamente a nova empresa de armazenagem de café ultrapassou as duas companhias locais do ramo: a Companhia Registradora de Santos, que registrava os contratos de compra e venda de café, e a Companhia Paulista de Armazéns Gerais, que dava facilidade para o depósito dos grãos e se orgulhava de ser "a única companhia de armazéns gerais fiscalizada pelo governo." 342 A primeira contava com capital de Rs 1.000:000\$000, e a segunda com Rs 400:000\$000. ${ }^{343}$ Pelo valor de 650 réis por saca, o produtor de café tinha direito ao “carreto da estação até o porto, ensaque à máquina, barbante, marcação e separação dos sacos, tiragem de amostras, seguro contra fogo e armazenagem por até 6 meses." ${ }^{344}$ No ano de 1911, a Companhia Paulista de Armazéns Gerais possuía uma dívida de Rs

\footnotetext{
${ }^{339}$ PERISSINOTO, Renato, obra citada, p. 65

${ }^{340}$ HOLLOWAY, Thomas, obra citada, p. 24.

${ }^{341}$ DEAN, Warren, A industrialização de São Paulo (1880-1945). São Paulo: Difusão Europeia do Livro, 1971 , p. 62.

342 BRASIL, Correio Paulistano, Arquivo Público do Estado de São Paulo,06 de julho de 1909, p. 08.

343 BRASIL, Impressões do Brazil no século XX. Lloyd's Greater Britain Publishing Company, Arquivo Municipal de Cubatão, 1913, p. 707.

${ }^{344}$ BRASIL, Correio Paulistano, Arquivo Público do Estado de São Paulo, 19 de dezembro de 1909, p. 9 
1.067:249\$215 com a Brazilian Warrant Company, cuja atuação mais competitiva no mercado contribuiu para desbancar sua concorrente nacional. ${ }^{345}$

Em 1903 legislou-se pela primeira vez a respeito dos warrants, conhecidos como títulos dos armazéns gerais. Em 21 de novembro daquele ano, sob o Ministério da Fazenda de Leopoldo de Bulhões, foi promulgada a lei 1102 de 1903; a partir de então o governo federal designava quais eram as alfândegas em condições de emitir os títulos sobre as mercadorias recolhidas em seus armazéns. Estes últimos estavam sob fiscalização imediata das Juntas Comerciais, para onde os empresários deveriam remeter os balanços das mercadorias que tivessem entrado e saído, bem como uma demonstração do movimento dos títulos emitidos. ${ }^{346}$ As mercadorias armazenadas só poderiam servir de base à emissão dos títulos se seguradas contra riscos de incêndio, e os armazéns gerais tinham apólices especiais para este fim. ${ }^{347}$

Podemos ter uma ideia a respeito do valor dos seguros realizados para a exportação do café a partir dos dados da Companhia Docas de Santos sobre os warrants emitidos em 1914. A sociedade, comandada pelos comerciantes fluminenses Eduardo Guinle e Cândido Gafrée, era responsável pelo funcionamento do porto de Santos desde 1892, não possuía garantia de juros e passou a ser efetivamente lucrativa apenas no ano de 1896. ${ }^{348}$ Em 1914, sabemos que a companhia emitiu 82 recibos e dez warrants sobre 8.023 sacas de café armazenadas e prontas para serem exportadas. ${ }^{349}$ Para segurar essa quantidade de café foram gastos Rs 260.990\$000 com apólices; considerando os dados do Relatório do Ministério da Fazenda de 1914, segundo o qual o preço da saca de 60 quilos de café exportada por Santos, naquele ano, era de Rs 39\$016, tem-se que o gasto com seguros representou $83 \%$ do valor da saca. ${ }^{350}$

A título de comparação, sabemos que em 1907, quando o capital empregado na produção cafeeira em São Paulo era de aproximadamente Rs 1.700:000.000.000, gastavase cerca de Rs $15.300 \$ 000$ para produzir $50 \mathrm{~kg}$ de café. A essa soma, adicionava-se cerca de Rs $5.950 \$ 000$ de gastos com seguros, transportes, armazenagens e comissões. ${ }^{351}$ Em

\footnotetext{
345 SCHOMPRÉ, Émile Quoniam. La Bourse de São Paulo. Typographia Casa Garrauz. São Paulo, 1911, p. 162.

${ }^{346}$ BRASIL, Decreto 1102, 21 de novembro de 1903, Coleção de Leis do Brasil, vol. 01, p. 1900.

${ }^{347}$ Ibidem, p. 1900, artigo 16.

${ }^{348}$ SAES, Flávio Azevedo, A grande empresa de serviço público na economia cafeeira (1850-1930). São Paulo: Hucitec, 1986, p. 128.

349 BRASIL, Relatório do Ministério da Fazenda, 1914, p. 70.

${ }^{350}$ BRASIL, Relatório do Ministério da Fazenda, 1914, p. 91.

${ }^{351}$ BRASIL, Correio Paulistano, Arquivo Público do Estado de São Paulo. 19 de fevereiro de 1907, p. 01. Os valores em mil réis foram calculados a partir dos originais em francos, considerando que 425 réis equivaliam a 1 franco (câmbio apresentado pelo Correio Paulistano para a referida data.)
} 
novembro de 1908, um produtor de café de Jaú que quisesse exportar 100 sacas de sua produção para Santos gastaria Rs $64 \$ 000$ para conduzir os alqueires para as máquinas; Rs $120 \$ 000$ para beneficiar 400 arroubas de café; Rs $170 \$ 000$ para 100 sacos novos; Rs $422 \$ 000$ para o frete das 100 sacas para Santos; Rs $40 \$ 000$ para o carreto em Santos, cobrado pelo comissário; Rs $72 \$ 000$ de comissão (tomando por base a cobrança de $8 \%$ para cada Rs $4 \$ 000$, ou $10 \mathrm{~kg}$ ); Rs $40 \$ 000$ e carreto para bordo, a Rs 400 a saca; Rs $29 \$ 200$ em seguros contra fogo; Rs $30 \$ 000$ para as Docas; Rs $25 \$ 000$ para comissão despachante na Alfândega; Rs 248\$400 em juros não especificados e Rs 317\$000 para compra de moeda estrangeira. Temos, portanto, que os gastos da fazenda até Santos totalizavam Rs 1:577\$600. ${ }^{352}$

A Companhia Paulista de Armazéns Gerais, proprietária de depósitos da cidade de Santos, vendia seguros contrafogo para armazenar o café e cobrava cerca de 15 réis mensais por cada saca, ou 6 réis semanais. Além do seguro havia o preço do armazenamento, de 125 réis mensais por saca. Para o embarque do produto, incluindo carreto, marcação dos sacos e despacho na Mesa de Rendas, pagava-se 350 réis por saca; os ensaques eram feitos via máquinas, e desde 1909 a companhia possuía em seus armazéns aparelhos de beneficiamento ou rebeneficiamento dos grãos, serviço realizado no momento do ensaque e considerado de baixo custo, cujos efeitos aumentavam o valor da mercadoria exportada. ${ }^{353}$

A Companhia havia sido fundada como sociedade anônima em 1906 e desde então gozava de garantia de juros de 6\% por parte do Estado de São Paulo. Em seu balanço referente a junho de 1910, temos que as apólices de seguros constituintes de seu patrimônio tinham o baixo valor de Rs 13:240\$830, formando apenas 0,8\% do total dos ativos (o maquinário dos armazéns de Santos e São Paulo, por exemplo, representava cerca de 12,3\% do ativo total). ${ }^{354}$ A Companhia Paulista de Armazéns gerais também concedia seguros para os bens que armazenava, e através desse serviço obteve o valor de

\footnotetext{
${ }^{352}$ Cabe chamarmos atenção para o fato de que os valores citados foram obtidos a partir de transcrição parlamentar publicada Correio Paulistano em novembro de 1908, onde deputados de São Paulo debatiam o orçamento federal para o ano de 1909; injuriados contra o que consideravam excessiva tributação sobre a produção exportada, apresentaram os referidos dados ne tentativa de serem menos taxados. Diante das possibilidades de taxação apresentadas pelo Tesouro, afirmaram os deputados paulistas: “(...) prenunciamos, deante disso, o perigo de greve geral neste Estado (...). Chegando a este máximo, é preciso retrogradar, e o governo do Estado não tem o direito de arrecadar tão grandes quantias, extorquidas da lavoura, quando é certo que ela morre de inanição". BRASIL, Correio Paulistano, Arquivo Público do Estado de São Paulo, 25 de novembro de 1908, p. 02.

${ }^{353}$ BRASIL, Correio Paulistano, Arquivo Público do Estado de São Paulo. 06 de julho de 1909, p. 08.

${ }^{354}$ SCHOMPRÉ, Émile Quoniam. La Bourse de São Paulo. Typographia Casa Garrauz. São Paulo, 1911, p. 162.
} 
Rs 12:333\$996, cerca de 2,6\% do lucro total para o ano social de 1910. A maior parte do lucro, no entanto (62\% do total), vinha do ensacamento do café.

Delegar serviços com necessidade de maquinaria moderna às companhias de armazenamento fazia sentido, sobretudo no caso dos pequenos produtores; em julho de 1909, a importante fazenda de café Rosa Branca, localizada em Caconde, no interior de São Paulo, teve sua principal máquina para beneficiamento do café inteiramente queimada. O equipamento não estava seguro e cerca de 800 arrobas de café também foram consumidas pelo fogo, o que acarretou um prejuízo total de Rs 30:000\$000. ${ }^{355}$

A pujança da produção e comercialização do café no Estado de São Paulo permitiu a formação de outras companhias de armazéns gerais, dedicadas à armazenagem e à emissão dos warrants. Além da Companhia Paulista de Armazéns Gerais, desde 1907 Santos e São Paulo também contavam com os serviços da Companhia Central de Armazéns Gerais, cujo capital social em 1911 era de Rs 500:000\$000, divididos em 2.500 ações de Rs $200 \$ 000$ cada, e as ações eram negociadas na Bolsa de Santos. ${ }^{356}$ Havia também a Companhia Internacional de Armazéns Gerais, igualmente fundada em 1907, com ações cotadas nas Bolsas de São Paulo e Santos e tendo como presidente Rodolfo Crespi, proprietário do famoso Cotonifício Crespi e da Banca Italiana di Sao Paolo. 357

Além da Companhia Nacional de Armazéns Gerais e sua equivalente paulista, a Companhia Paulista de Armazéns Gerais, também funcionava no Brasil, desde 1912, a Companhia Internacional de Armazéns Gerais, cujo alcance financeiro e a relação com seguradoras era mais ampla que suas congêneres nacionais. A partir dos balanços da Companhia para o ano de 1912 temos que sob sua responsabilidade estavam muitas apólices de seguros de sociedades estrangeiras que totalizavam valores bastante altos, como a Northern Assurance (Rs 1.100:000\$000), a Preussische National (Rs 800:000\$000), a Alliance Assurance (Rs 700:000\$000) e a Royal Insurance (Rs 500:000\$000), além das nacionais Companhia Paulista de Seguros ( Rs 756:000\$000), a Equitativa (Rs 500:000\$000) e a Albingia (Rs 300:000\$000), num total de Rs 4.656:000\$000 em apólices de seguros que compunham seu ativo. ${ }^{358} \mathrm{O}$ estoque depositado no armazém naquele mesmo período correspondia a Rs 4.022:312\$000, e a Companhia Internacional de Armazéns Gerais também concedia, ela própria, seguros às

\footnotetext{
355 BRASIL, Correio Paulistano, Arquivo Público do Estado de São Paulo, 19 de julho de 1909, p. 03.

${ }^{356}$ SCHOMPRÉ, Émile Quoniam. La Bourse de São Paulo. Typographia Casa Garrauz. São Paulo, 1911, p. 160.

357 Ibidem, p. 160.

${ }^{358}$ BRASIL, Correio Paulistano, Arquivo Público do Estado de São Paulo, 30 de março de 1913, p. 08.
} 
mercadorias armazenadas em seu espaço; desse serviço, em 1913, obteve Rs 5:794\$100 em prêmios.

Em março de 1908 o Banco União do Commercio, da cidade de São Paulo, foi obrigado a pedir liquidação devido a transações creditícias má sucedidas, após envolverse com a compra de warrants de café no valor de Rs 5.000:000\$000. As dificuldades em recuperar o dinheiro investido nos títulos, bem como uma corrida dos depositantes, levaram o estabelecimento à falência, não sem antes ter buscado recuperar sua liquidez tentando descontar letras de Rs 400:000\$000 no Banco da República, que se recusou a realizar a operação. ${ }^{359}$

O caso chama atenção pois logo após os boatos a respeito da insolvência do Banco União do Commercio terem se espalhado e atingido a imprensa, uma série de instituições vieram a público declararem não terem sido afetadas negativamente pela falência do banco, dentre elas a Associação de Empregados no Comércio e a Companhia de Seguros Mercúrio. ${ }^{360} \mathrm{Em} 1908$, a possibilidade de crises financeiras afetarem a produção era uma ameaça já conhecida e possível de ser antecipada pelo público, e os encadeamentos de crédito tornavam a interrupção de pagamentos de uma única instituição um problema de razoável gravidade, daí a preocupação por parte das instituições de crédito de declararem publicamente sua boa situação de solvência. A crise em questão era em grande parte fruto da interrupção de pagamentos de estoques de café por parte dos EUA, logo após a entrada em vigor da Lei dos Trustes (Sherman Act), a qual nos referiremos mais adiante. ${ }^{361}$

Já mencionamos a mudança no padrão de comercialização do café, cuja monopolização pelas casas exportadoras estrangeiras tornou anacrônica a figura do comissário. Cabe agora relacionarmos a referida mudança no padrão de exportação cafeeiro ao papel das companhias de seguros entre os anos de 1889 e 1914. De fato, a infraestrutura das casas exportadoras estrangeiras possibilitou a ampliação do volume de café exportado; parece-nos bastante verossímil a hipótese de que, sob as novas condições de distribuição da mercadoria, as seguradoras passassem a exercer papel cada vez mais relevante na cadeia de valor do café. Podemos comprovar a relação estreita entre as

\footnotetext{
${ }^{359}$ BRASIL, Correio Paulistano, Arquivo Público do Estado de São Paulo, 06 de março de 1908, p. 01. 360 Ibidem, p. 01.

${ }^{361}$ Sabemos que desde sua promulgação em 1890 e durante as primeiras décadas do século XX, a Sherman Act foi responsável por punições e processos de companhias de seguros acusadas de monopólios e formação de trustes, como no caso de cento e nove seguradoras processadas pelo Supremo Tribunal dos EUA em abril de 1913, todas acusadas de transgredirem as disposições daquela lei. BRASIL, Correio Paulistano, Arquivo Público do Estado de São Paulo, 28 de abril de 1913, p. 04.
} 
companhias de seguros e as casas exportadoras de Santos a partir dos dados do Arquivo Histórico de Cubatão.

Dentre as mais importantes casas exportadoras de café do final do século XIX e início do XX no Brasil estava a E. Johnston \& Co., companhia inglesa com escritório central em Londres que se estabeleceu no Rio de Janeiro no ano de 1842 e em Santos em 1882. ${ }^{362}$ Para a exportação do café, a E. Johnston \& Co. possuía sucursais em Taubaté, Amparo, Espírito Santo do Pinhal, São José do Rio Pardo, Ribeirão Preto, São Carlos do Pinhal, Jaboticabal, Jaú e São Manoel; em 1910 exportou um total de 642.119 sacas de café. Também funcionou como importadora, tendo trazido artigos manufaturados como máquinas e balanças das firmas britânicas Avery \& Co. Ltd e Sack Sewing and Filling Syndicate Ltd.

Em 1911 a E. Johnston passou a ter seu próprio departamento de seguros, negociando sistematicamente a proteção das sacas de café com a Guardian Assurance Co., firma britânica fundada em 1821 e de quem a própria E. Johnston era agente. O departamento estava a cargo de Robert Alexander Landall, cônsul inglês em Santos; segundo dados da época, "de ano para ano se tem registrado um aumento contínuo no departamento de seguros da E. Johnston \& Co.”. 363

Dentre as poucas firmas exportadoras brasileiras que funcionavam à época, citamos a Companhia Exportadora de Café de Santos. A respeito da inserção do capital nacional no âmbito do comércio exportador, em 1913 dizia-se que "o elemento brasileiro (...) tem aberto olhos à importância da sua participação no comércio de exportação de café e várias empresas se têm organizado com tal objetivo."364

A companhia formou-se em princípios de 1911, após absorver as funções da antiga casa exportadora Barbosa \& Co., esta última fundada em 1901 e com papel proeminente no comércio de Santos. Logo do início do seu funcionamento, a Companhia Exportadora de Café de Santos possuía o capital de Rs 1.000:000\$000, dividido em 5.000 ações de Rs $200 \$ 000$ cada, valor rapidamente subscrito, na sua maioria, por fazendeiros do Estado de São Paulo e por comissários de Santos. Além de cuidar da exportação, a firma comprava diretamente o café nas fazendas, tomava consignações para importação de produtos estrangeiros, e representava companhias de navegação e de seguros, fossem

\footnotetext{
${ }^{362}$ BRASIL, Impressões do Brazil no século XX. Lloyd's Greater Britain Publishing Company, Arquivo Municipal de Cubatão, 1913, p. 723.

${ }^{363}$ BRASIL, Impressões do Brazil no século XX. Lloyd's Greater Britain Publishing Company, Arquivo Municipal de Cubatão, 1913, p. 720

${ }^{364}$ Ibidem, p. 720
} 
nacionais ou estrangeiras. Segundo texto publicado no almanaque Impressões do Brasil no Século XX, a companhia brasileira tinha atividades muito "racionais" e altas pretensões de crescimento, com vistas de estabelecer agências em Nova York, Hamburgo, Havre e "outros centros, como permitirem as circunstâncias." 365

Citaremos o caso de uma firma importadora que se interessou pela exportação e, em consequência, pelo ramo de seguros. A Schmidt, Trost \& Cia possuía matriz em São Paulo e uma casa filial em Santos que operava como agência de remessas de mercadorias consignadas à casa matriz; dentre os bens importados havia aço, madeira, cimento, cutelaria, e materiais de construção. Segundo os dados do mesmo Impressões do Brazil no século XX, a Schmidt, Trost \& Cia. "no gênero de importação e exportação em geral, sustenta importante negócio, e em linhas de navegação e companhias de seguros representa avultados interesses." 366 Na sua seção de importação, a firma negociava ferragens, ferro bruto, aço, arame, metais, materiais para construção, ferramentas, óleos e tintas. Seu acesso aos produtos europeus fazia-se via uma casa de compras localizada na importante cidade portuária de Hamburgo, Alemanha, posição privilegiada que também a possibilitava de, ocasionalmente, operar em transações bancárias com firmas europeias. A exportação, por outro lado, consistia apenas em café, produzido em propriedades da própria firma no Estado de São Paulo; no período de 1895-06 a 1908-09, 1.078.570 sacas de café foram exportadas de Santos por esta firma. No ano 1909-10, as suas exportações foram de 112.236 sacas. ${ }^{367}$

No âmbito das casas comissárias, cuja inserção a partir da década de 1890 começa a minguar, citaremos o caso de uma firma que ainda no século XX participava da cadeia de comercialização do café, a Ernesto Whitaker \& Cia. Fundada em 1908 por fazendeiros paulistas, a companhia comprava e exportava cerca de 100.000 sacas de café anuais, comércio que por sua vez sustentava o adiantamento de serviços e a concessão de crédito aos fazendeiros. ${ }^{368}$ A esse respeito, sabemos que à época os comissários compradores de mercadorias e fornecedores de crédito eram os próprios fazendeiros de café. ${ }^{369}$

\footnotetext{
${ }^{365}$ BRASIL, Impressões do Brazil no século XX. Lloyd's Greater Britain Publishing Company, Arquivo Municipal de Cubatão, 1913, p. 720

366 Ibidem, p. 707

${ }^{367}$ BRASIL, Impressões do Brazil no século XX. Lloyd's Greater Britain Publishing Company, Arquivo Municipal de Cubatão, 1913,p. 707

${ }^{368}$ Ibidem, p. 708.

${ }^{369}$ SAES, Flavio, A grande empresa de serviços públicos na economia cafeeira, (1850-1930). São Paulo: Editora Hucitec, 1985
} 
Um dos sócios e gerente geral Ernesto Whitaker \& Cia era o secretário da Associação Comercial de São Paulo, Frederico Ernesto de Aguiar Whitaker Jor, por sua vez primo do famoso José Maria Whitaker, ex-presidente da Associação Comercial de Santos, ex-presidente do Banco do Brasil, e futuro Ministro da Fazenda do primeiro governo de Getúlio Vargas. A Ernesto Whitaker \& Cia possuía títulos de empresas comerciais tais como a Companhia Exportadora de Frutas, de Santos, e a Companhia Brazileira de Seguros. ${ }^{370}$

2.5. As consequências do Encilhamento e o papel das companhias de seguros na formação $\underline{\text { do capital industrial brasileiro }}$

Já nos referimos às companhias de seguros como importantes instituições cujo funcionamento permitiu a contínua precaução ao risco por parte das firmas brasileiras no final do século XIX e início do XX. A garantia ao transporte de mercadorias e a acidentes no maquinário de fábricas, por exemplo, proporcionaram maiores possibilidades de acumulação de capital, já que os custos de transação se reduziam e os ganhos de produtividade aumentavam. A existência de uma rede de proteção capaz de garantir a ocorrência de sinistros serviu de estímulo ao investimento e à construção de novos negócios; é a partir desse cenário que podemos afirmar a importância das companhias de seguros para a aceleração do processo de formação do capital industrial brasileiro. Ao diminuírem a possibilidades de acidentes e prejuízos, as firmas seguradoras estimulavam o investimento e as tomadas de riscos por parte das manufaturas nacionais, em especial ascensão desde a década de 1890 .

A discussão em torno do processo de formação do capital industrial brasileiro perpassa necessariamente pelo momento do Encilhamento e pela função que este último desempenhou para a construção da indústria nacional. Cabe aqui chamarmos atenção para o fato de que alguns autores interpretaram o clima de euforia do Encilhamento como capaz de ter legado heranças positivas para a economia real brasileira. ${ }^{371} \mathrm{O}$ crescimento da indústria têxtil durante a década de 1890 e nos anos seguintes, por exemplo, denotaria a possibilidade de investimentos sólidos a partir da bolha especulativa, da desvalorização

\footnotetext{
${ }^{370}$ BRASIL, Impressões do Brazil no século XX. Lloyd's Greater Britain Publishing Company, Arquivo Municipal de Cubatão, 1913, p. 708

${ }^{371}$ SUMMERHILL, William, Inglorious Rvolution: Political Institutions, Sovereign Debt, and Financial Underdevelopment in Imperial Brazil. Yale University Press, 2015, p. 221. Segundo o autor: « The stock market speculation that began in 1889 and continued unti 1891 had some durable effects on the real sector of the economy, but not many. »
} 
cambial e da inflação. O período de alta do câmbio, entre 1889 e 1890, seguido pela desvalorização de 1891, permitiu, respectivamente, o aumento da importação de bens de capitais e um melhor posicionamento das mercadorias nacionais no mercado estrangeiro. ${ }^{372}$ Tem-se assim um duplo beneficiamento para o incipiente capital industrial nacional: as importações de bens de capital da Inglaterra, em libras, aumentaram cerca de $70 \%$ entre 1885-1889 e 1890-1894. ${ }^{373}$ As fábricas de tecido tiveram seu capital aumentado quatro vezes num período de três anos, e das 198 fábricas em operação no ano de 1912, 33 foram fundadas no período 1885-1889. ${ }^{374}$

De fato, pode-se comprovar uma significativa mudança no padrão das importações, cujos efeitos para a expansão da indústria mostraram-se fundamentais. Como dito acima, a partir de 1870 os produtos que aqui aportaram deixaram de basear-se apenas nos bens de consumo e passam a incluir maquinário, insumos e capital circulante. Se em 1850-4 a maquinaria importada representava apenas 0,85 do valor das importações advindas da Inglaterra, trinta anos depois passa a valer 6,52 por cento, para chegar a 9,96 entre 1905-09. ${ }^{375}$ A importação de carvão também conheceu crescimento expressivo, passando de 4,13 por centro do que era importado da Grã-Bretanha em 1850-4 para 13,91 em 1900-04. ${ }^{376}$

À época do Encilhamento, as firmas importadoras britânicas obtinham empréstimos junto ao Banco da Inglaterra para obter dinheiro em caixa e, dessa forma, concederem elas próprias crédito aos brasileiros para que comprassem máquinas importadas. ${ }^{377}$ Por meio das casas importadoras, a incipiente indústria doméstica obtinha possibilidades de acesso à bens de capital estrangeiros; apesar da conjuntura de crise e falências, a primeira década republicana de alguma forma legou consequências permanentes à inciativa empresarial nacional.

Por mais que se verifiquem algumas heranças sólidas advindas da euforia do Encilhamento, rapidamente buscou-se controlá-lo, sobretudo devido à trajetória ascendente da inflação. As primeiras tentativas de saneamento vieram por parte do Congresso, após a saída de Rui Barbosa do Ministério da Fazenda, em fevereiro de 1891.

\footnotetext{
372 TANNURI, Luiz Antonio, obra citada, p. 73.

${ }^{373}$ FISHLOW, A., "Origens e consequências da substituição de importações no Brasil", Estudos econômicos, (6), dezembro de 1962, P. 7-75, apud TANNURI, Luiz Antonio, obra citada, p. 72.

${ }^{374}$ FISHLOW, Albert, "Origens e consequência da substituição de importações no Brasil", em Formação

Econômica do Brasil: a experiência da industrialização, série ANPEC, Edição Saraiva, 1977, p. 11.

${ }^{375}$ GRAHAM, Richard, obra citada, p. 139.

376 Ibidem, p. 134.

377 GRAHAM, Richard, obra citada, p. 140.
} 
Seu sucessor, Tristão de Araripe, permaneceu muito pouco tempo no cargo, sendo rapidamente substituído pelo barão de Lucena. Este último de fato se propôs a dar continuidade à política expansionista dos meses anteriores; socorreu a praça financeira com a concessão de Rs 25.000:000\$000, aumentou o limite de emissões e utilizou recursos para a reorganização do Banco da República. ${ }^{378}$

A euforia do esquema de Rui Barbosa, no entanto, não era mais bem aceita pelo Congresso, que em julho do mesmo ano, via requerimento do deputado Demétrio Ribeiro, votou pelo projeto de lei que restringia a emissão de moeda. ${ }^{379}$ Segundo Prudente de Moraes, à época presidente do Senado, durante a formulação do orçamento para o ano de 1892, o Congresso trabalhava na direção de restringir os gastos e mudar o rumo da política fiscal levada à cabo até então:

As comissões de orçamento do Congresso, de uma das quais eu tinha a honra de fazer parte, (...) haviam adoptado patrioticamente o alvitre de reduzir as despesas sem desorganizar serviços uteis, indo buscar na receita o imprescindível para equilibral-as com aquellas, quando foi sorprehendida a Nação pelo ato dictatorial da dissolução do Congresso, cujos trabalhos ficaram interrompidos. ${ }^{380}$

Os limites impostos às propostas de política econômica do barão de Lucena, aliado de Deodoro da Fonseca, impulsionaram o golpe de Estado de 03 de novembro de 1891, batizado à época como o "golpe da bolsa". ${ }^{381}$ Deodoro fechou o Congresso, porém rapidamente renunciou e entregou a presidência ao se vice, Floriano Peixoto, em 23 de novembro de 1891. Agora, sob a gestão de Rodrigues Alves na pasta da Fazenda, iniciavase o "irreversível combate ao Encilhamento". ${ }^{382}$

Ao assumir seu novo posto, afirmou Rodrigues Alves:

Tem sido objeto das mais sérias preocupações no paiz a crise econômica e financeira com que lutamos affectivamente ha muitos mezes. A baixa constante do cambio, attingindo a uma taxa desesperadora, a desvalorização de todos os

\footnotetext{
${ }^{378}$ BRASIL, Relatório do Ministério da Fazenda, 1892, p. 68

${ }^{379}$ Ibidem, p. 68

${ }^{380}$ Ibidem, p. 68

${ }^{381}$ FAORO, Raimundo, obra citada, vol. II, p. 516.

382 Ibidem, p. 516.
} 
títulos, a retraccção do capital, o receio do decrescimento das rendas publicas de um lado, e o de outro a carestia de generos de primeira necessidade. ${ }^{383}$

Segundo o novo Ministro da Fazenda, no entanto, os altos preços do café, sustentados pela forte demanda externa, seriam garantia de uma saída da crise financeira:

Si a colheita, de café principalmente, de 1892 e 1893 deve ser menor do que a antecedente, os preços do produto tem se conservado em alta, que muito provavelmente acompanhará as flutuações do cambio. Com a riqueza de taes produtos e seu grande valor de exportação, não é lícito desanimar ante dificuldades de qualquer natureza. ${ }^{384}$

A alta do preço do café manteve-se entre os anos de 1886 e 1896; segundo Ana Célia Castro, os cafeeiros plantados até 1886 se tornariam plenamente produtivos apenas em 1891, época morna no que diz respeito à demanda do mercado externo. ${ }^{385} \mathrm{O}$ início da década de 1890 foi marcado pelo paradoxo entre a queda dos preços do produto, menos consumido internacionalmente que outrora, e as desvalorizações cambiais, que estimulavam a busca por novas plantações. ${ }^{386}$

A alta inflação e a deterioração do mil réis, que marcaram a economia desde 1890 até o saneamento de 1900, reduziram o valor da dívida interna enquanto tornaram a externa mais cara. Os problemas fiscais acumularam-se ao longo da década e culminaram no calote de 1898; era a primeira vez que o país vivenciava um calote junto de seus credores externos. ${ }^{387}$ Apesar de ao longo de todo o Império o Brasil ter sido bem-sucedido no cumprimento de suas obrigações financeiras, em 1898 o governo não liquidou sua dívida com Londres. Após ter sido reinserido no mercado de capitais várias vezes logo no início do século XX, em 1914 o país deu novo calote e rapidamente passou a compor o rol dos excluídos dos fluxos de capital financeiro estrangeiro. ${ }^{388}$

Ainda que o saneamento da economia pós Encilhamento seja consensualmente apresentado como referente ao governo Campos Salles (entre 1898 e 1902, quando Joaquim Murtinho esteve à frente do Ministério da Fazenda), pode-se tomar como primeira tentativa para resolução da crise as medidas da administração de Serzedelo

\footnotetext{
${ }^{383}$ BRASIL, Relatório do Ministério da Fazenda, 1891, p. 17

${ }^{384}$ BRASIL, Relatório do Ministério da Fazenda, 1891, p. 19.

${ }^{385}$ CASTRO, Ana Célia, obra citada, p. 59.

386 Ibidem, p. 59.

387 SUMERHILL, William, obra citada, p. 223.

388 SUMERHILL, William, obra citada, p. 13.
} 
Correia no mandato de Floriano Peixoto; neste governo buscou-se o fim da emissão excessiva a fim de estabilizar a moeda. Alguns autores foram taxativos ao afirmarem que "Floriano e Serzedelo fizeram o governo mais pró indústria que o Brasil teve até 1930." 389

No que diz respeito ao debate teórico acerca da origem do capital industrial brasileiro, este último é extenso e considera o final do século XIX como um momento bastante emblemático. ${ }^{390}$ Apesar de não pretendermos entrar nessa discussão, chamaremos atenção para alguns fatos a respeito do desenvolvimento industrial brasileiro, cujo escopo abrange o recorte temporal deste trabalho.

É sabido que durante o período da abolição e da imigração, o Brasil conheceu maior necessidade de importar alimentos e wage goods, isto é, bens de consumo manufaturados que compõem a cesta dos trabalhadores assalariados. ${ }^{391}$ Os primeiros ensaios da industrialização brasileira substituíram uma faixa de bens leves e relativamente fáceis de serem produzidos no âmbito da economia doméstica. Dessa forma os salários do complexo exportador foram garantidos internamente, isto é, o que era consumido pelo mercado de trabalho em formação era produzido no Brasil. Se a reprodução da força de trabalho era realizada internamente, outros bens e fatores de produção mais complexos precisavam ser importados. ${ }^{392}$

Cabe, no entanto, chamarmos atenção ao fato de que essa substituição ocorria na fase primário exportadora da economia nacional e não poderia, portanto, ser denominada como um processo de industrialização propriamente dito. De acordo com essa visão, as substituições não ocorreram devido a choques adversos, os quais o Brasil conheceria tão bem a partir da Primeira Guerra Mundial, e sim a partir de um grande volume de exportação, sobretudo de café. ${ }^{393} \mathrm{Na}$ industrialização por expansão das exportações, haveria apenas adição de novas unidades de produção similares às preexistentes, mediante importação de equipamentos; a industrialização por expansão das exportações, portanto, não criaria seu próprio dinamismo, pois a demanda não era autogerada.

Em linhas gerais, pode-se dizer que o processo acima descrito diz respeito à formação do capital industrial paulista, cujo percurso histórico difere do fluminense em

\footnotetext{
389 SCHULZ, John, obra citada, p. 34.

${ }^{390}$ A respeito das principais interpretações acerca do processo de industrialização brasileiro, seus debates e questões não resolvidas, Cf. SUZIGAN, Wilson, Indústria Brasileira: origem e desenvolvimento. São Paulo: Editora Brasiliense, 1986, p. 22.

${ }^{391}$ CARDOSO DE MELLO, João Manuel, O Capitalismo Tardio. São Paulo: Editora Brasiliense, 1982

392 Idem, p. 105. Afirma o autor: "A acumulação de meios de produção e o consumo capitalista se financiam com a capacidade para importar do próprio complexo exportador cafeeiro."

393 CARDOSO DE MELLO, João Manuel, O Capitalismo Tardio. São Paulo: Editora Brasiliense, 1982p. 90.
} 
alguns pontos centrais. Sabe-se que a indústria do Rio de Janeiro, antes da ascensão paulista, era a mais avançada; o porto permitiu ao desenvolvimento local a rápida importação de combustíveis e insumos, e o mercado financeiro da praça carioca, cenário do Encilhamento, já na década de 1880 era bastante desenvolvido. ${ }^{394}$ A partir da década de 1870/80, o Rio de Janeiro perdeu espaço como cidade exportadora de café para Santos; o declínio da produção do Vale do Paraíba fluminense não pode, no entanto, ser generalizado como equivalente a um declínio de toda a economia local. Aos poucos a província garantiu seu dinamismo econômico assumindo-se como centro de distribuição de mercadorias importadas, bem como através do desenvolvimento do seu porto e da condição política central, ligada à burocracia estatal residente. ${ }^{395}$

As companhias de seguros participaram desses primeiros ensaios da industrialização brasileira como instituições diminuidoras de riscos e prejuízos, atuando em distintas frentes como garantidoras de acidentes com operários e destruição de maquinário. A seguir apresentaremos sucessivos exemplos da atuação dessas firmas no processo de construção do capital industrial nacional.

Sabemos que após a abolição da escravidão, em 1888, o Sudeste brasileiro conheceu uma ampla entrada de imigrantes que, junto dos antigos escravos e da classe de homens livres pobres, lentamente formavam um mercado de trabalho nacional. No final do século XIX e início do XX, aos poucos o trabalho livre (e por vezes assalariado) espalhava-se pelo país, sobretudo nos centros urbanos como Rio de Janeiro e São Paulo. Já nessa época era possível encontrar seguros para máquinas e contra acidentes no trabalho, bem como associações de formação de pecúlio específicas para trabalhadores, seguros para fábricas, máquinas e operários. Esses casos denotam a complexificação produtiva do país, cujo processo de formação de um mercado interno estava em marcha.

As notícias a respeito do aperfeiçoamento da legislação trabalhista na Europa, bem como sobre a construção de companhias de seguro operárias, chegavam aos poucos ao Brasil via imprensa, e podemos concluir que influenciaram a construção do nosso próprio setor. Em dezembro de 1906, o Correio Paulistano publicava e existência de uma lei de seguros operários contra moléstias na Alemanha, a partir da qual cerca de Rs

\footnotetext{
${ }^{394}$ LEVY, Maria Bárbara, A indústria do Rio de Janeiro através das suas sociedades anônimas. Rio de Janeiro: Editora UFRJ, 1994. p.136. Para os autores da tradição do capitalismo tardio, o Encilhamento marca o início de uma acumulação de capital industrial no Brasil. $\mathrm{M}^{\mathrm{a}}$ Barbara Levy os critica por tratarem do caso paulista como referencial para todo o processo de industrialização brasileiro, e por reduzirem os distintos processos de industrialização no Sudeste ao binômio café/indústria.

${ }^{395}$ LEVY, Maria Bárbara, A indústria do Rio de Janeiro através das suas sociedades anônimas. Rio de Janeiro: Editora UFRJ, 1994, p. 135
} 
7.000:000\$000 seriam gastos por empregadores e governo no tratamento de tuberculose de trabalhadores entre os anos de 1901 e $1905 .{ }^{396}$ Dois anos mais tarde, o jornal publicava o fato da Alemanha contar com 600 cooperativas para construção de casas populares para funcionários das fábricas, e que as companhias de seguro locais contribuíram com Rs 20.000.000 de marcos para a construção de moradias operárias em 1904. 397

Aos poucos, no Brasil, o número de operários crescia. Entre 1889 e 1920 os trabalhadores fabris nacionais passaram de 50.000 para 300.000 , parte expressiva da ampliação da população urbana. ${ }^{398}$ A fundação no Rio de Janeiro, no início de 1897, da Sociedade de Seguros Mútuos Operária, preocupada com a criação de dotes, pecúlios e heranças via emissão de seguros, é bastante emblemática nesse sentido. Também no Rio de Janeiro, em 1908, foi fundada a Companhia de Seguros Cruzeiro do Sul, constituída como sociedade anônima com o capital de Rs 800:000\$000. Logo no início de seu funcionamento, a Cruzeiro do Sul possuía o alto valor Rs de 300:000\$000 depositado em títulos da dívida pública no Tesouro Nacional e cerca de 60.000 segurados contra acidentes. $^{399}$

A maioria dos seguros concedidos eram de vida, e a companhia tinha sucursais no Rio Grande do Sul, Paraná, Santa Catarina e no Pará. Em fevereiro de 1909, foi formada uma seção de seguros industriais contra acidentes, e em 1911 uma específica para acidentes contrafogo. Eram concedidos seguros individuais e coletivos; nesta última categoria, várias fábricas faziam entrar seus operários, cujo número, como sabemos, crescia de maneira notável no Brasil do século XX. ${ }^{400}$ Em 1909 a Cruzeiro do Sul segurava os operários da fábrica de tecidos Sant'Anna, em São Paulo, e Santa Luzia, no Rio de Janeiro, ambas propriedades da Companhia Nacional de Tecidos de Juta. ${ }^{401}$

Muitos são os exemplos da ampliação do capital industrial brasileiro no período em questão. Encontramos alguns casos de estabelecimentos fabris cujos donos estavam envolvidos com companhias de seguros, tendo participado de sua fundação ou mesmo da diretoria.

Foi o caso da Companhia de Seguros Mútuos Providência, em funcionamento no Rio de Janeiro desde 1898, que também segurava estabelecimentos fabris. Os seguros

\footnotetext{
${ }^{396}$ BRASIL, Correio Paulistano, 02 de dezembro de 1906, p. 05.

${ }^{397}$ BRASIL, Correio Paulistano, 18 de junho de 1908, p. 04.

398 VIOTTI DA COSTA, Emília da, obra citada, p. 423

${ }^{399}$ BRASIL, Correio Paulistano, 18 de junho de 1908, p. 04

400 VIOTTI DA COSTA, Emília da, obra citada, p. 475

${ }^{401}$ BRASIL, Correio Paulistano, Arquivo Público do Estado de São Paulo, 02 de setembro de 1909, p. 02.
} 
concedidos protegiam propriedades móveis ou imóveis, urbanas ou rurais, contra "fogo accidental ou proveniente de raio ou explosão a gaz"; também eram seguradas mercadorias embarcadas por mar ou por terra, em via férrea ou não, para qualquer parte do Brasil ou do exterior. ${ }^{402}$

Em 1907 foi fundada a Vasconcelos \& Cia., grande fábrica de selins, arreios, ações e equipamentos militares, cujo maquinário funcionava todo com energia elétrica. A firma, com sede em São Paulo, era também agente da Companhia Brasileira de Seguros, que operava seguros de vida, marítimos, terrestres e acidentes, e possuía sua própria seção bancária. Os seguros eram realizados para o território brasileiro, mas também para Portugal, Espanha, Itália e França, o capital era de Rs 250:000\$000 e eram empregados cerca de 60 operários na fábrica e 18 funcionários no escritório de seguros. ${ }^{403}$

Por fim citaremos o caso da Lebre Filho \& Cia, estabelecimento fabril e grande firma comercial formada no Rio de Janeiro no ano de 1894, ocupada com negócios de ferragens, tintas e munições. Também produzia e vendia peneiras, cordas, cabos de arame, ferro e aço, além de outros artigos de tecidos metálicos, todos artefatos à época difíceis de serem encontrados no Brasil e de alto valor agregado; em grande parte por isso, esses produtos alcançaram um amplo mercado para além de São Paulo, sendo exportados para outros Estados brasileiros. A firma era depositária da marca de ferro Leão, do sabão Perolina, do formicida Pascoal e dos vinhos da casa A. Romariz Filho; era também agente da Companhia de Seguros Aliança da Bahia, e contratava viajantes que vendiam seus produtos, dirigidos por atacado, a fazendas do interior. ${ }^{404}$

Já no final do século XIX identificamos no Sudeste brasileiro estabelecimentos manufatureiros cujos balanços citam gastos com seguros. Essas redes de prevenção ao risco construídas pelos próprios proprietários fabris garantiam mais segurança e estimulavam o risco, o que por sua vez levava à maior acumulação de capital por parte do negócio. Em balanço do segundo semestre de 1896, a Companhia de Fiação e Tecelagem Carioca fez referência ao gasto de Rs 27:576\$370 com seguros fabris, cerca de $8,5 \%$ de seus débitos totais para o período. ${ }^{405}$ No mesmo balanço a fábrica trata das suas más condições financeiras para o primeiro semestre de 1896, devidas sobretudo a

\footnotetext{
402 BRASIL, Actos do Poder Executivo, 1898, p. 682

${ }^{403}$ BRASIL, Impressões do Brazil no século XX. Lloyd's Greater Britain Publishing Company, Arquivo Municipal de Cubatão, 1913, p. 558.

${ }^{404}$ Ibidem, p. 689.

405 BRASIL, Diário Oficial da União, 18 de abril de 1897, p. 1782
} 
um forte aumento do preço do algodão, principal matéria prima utilizada pela manufatura. ${ }^{406}$

Também em 1896 funcionava em Belo Horizonte a Companhia de Fiação e Tecelagem Industrial Mineira, que em sua demonstração da conta de lucros e perdas para o primeiro semestre daquele ano gastou $9 \%$ dos débitos totais com seguros da fábrica. $\mathrm{O}$ estabelecimento cita gastos crescentes com maquinários para aperfeiçoamento do pano e classifica suas novas aquisições como "imprescindíveis em vista das exigências do mercado". ${ }^{407}$ A manufatura cita ainda os altos custos com fretes e transportes, os impostos e o câmbio baixo, encarecedor dos insumos importados, como responsáveis por maus resultados nos seus balanços daquele ano. ${ }^{408}$

Os seguros específicos às indústrias eram considerados pelas companhias os de maiores riscos; no caso de incêndio e destruição de objetos e construções das fábricas, na maior parte dos casos, as companhias tinham o direito de escolher se restituíam o segurado via substituição dos objetos em seu estado anterior ao sinistro, ou pagamento do dano a prazo, em letras de seis meses. No caso do sinistro a ser pago ser equivalente ou exceder o fundo de reserva ordinário, a companhia poderia escolher entre utilizar os recursos do fundo de receita extraordinário ou entregar ao segurado letras e mais juros de $10 \%$ ao ano. ${ }^{409}$

Em alguns momentos verificamos a realização de seguros totais, que garantiam o pagamento do sinistro de um estabelecimento inteiro; outras vezes o proprietário optava por realizar diferentes seguros, às vezes em distintas companhias, para proteger separadamente os diversos setores da propriedade. Em julho de 1909 o estabelecimento de torrefação do Café Guilherme, marca de propriedade do fazendeiro Antonio Carlos Melchert, sofreu um incêndio de grandes proporções, tendo sido arrasados os grãos e todo o maquinário. A propriedade era segurada em Rs 90:000\$000 pelas companhias Lloyd Americano e Previdente; as máquinas possuíam seguro separado de Rs 25:000\$000 e a armação da casa em Rs 5:000\$000 pela Companhia Paulista de Seguros. O prédio era alugado pelo Café Guilherme e estava seguro em Rs 30:000\$000 pela companhia Integridade. $^{410}$

\footnotetext{
${ }^{406}$ BRASIL, Diário Oficial da União, 18 de abril de 1897, p. 1780

${ }^{407}$ Ibidem, p. 1783

${ }^{408}$ Ibidem, p. 1783

${ }^{409}$ BRASIL, Impressões do Brazil no século XX. Lloyd's Greater Britain Publishing Company, Arquivo Municipal de Cubatão, 1913, p. 688

${ }^{410}$ BRASIL, Correio Paulistano, Arquivo Público do Estado de São Paulo, 21 de julho de 1909, p. 05.
} 
Em agosto de 1909, problemas nos fios elétricos da fábrica de tecidos Mariangela, de São Paulo, colocaram em risco a vida dos 400 operários contratados, desprovidos de seguros de vida e de qualquer tipo de proteção. Ao final os prejuízos ao proprietário foram poucos e puderam ser cobertos pelo seu seguro de Rs 4:000\$000. ${ }^{411}$ No mesmo mês de agosto e na mesma cidade, dias antes do referido ocorrido, um incêndio de imensas proporções destruiu por completo uma fábrica de véus para gás incandescente da firma Ghedini \& Prandini. A fábrica extraía substâncias de areias movediças (dentre elas o thorium) para o trabalho feito com gás; ao reivindicar o pagamento do sinistro pelas companhias de seguros União de Paris, Brazil e União dos Varegistas, afirmou ser o único estabelecimento na América Latina a realizar tal atividade. ${ }^{412}$

As apólices em cada seguradora totalizavam cerca de Rs 150:000\$000, quantia insuficiente para reparar os estragos causados pelo fogo e pela água. Antes do incêndio a firma tinha boas condições financeiras e maquinaria de boa qualidade, totalizando um capital de Rs 40:000\$000; além disso, os proprietários tinham planos de transformar a fábrica em uma sociedade anônima, cujo capital seria constituído por 2 mil ações integralizadas. ${ }^{413}$

Citaremos outros exemplos de estabelecimentos fabris segurados. A Sociedade Anônima Moinho Santista, fundada na cidade de Santos em 1905, gastou cerca de Rs 18:772 \$150 com seguros diversos, o equivalente a 5\% de seus débitos totais (mais do que o total contabilizado para gastos com impostos e comissões). ${ }^{414}$ A firma Peixoto \& Costa, formada em 1903 e que em 1913 possuía o capital de Rs 300:000\$000, estava envolvida no comércio de arroz, manufaturava tecidos de algodão e negociava a matéria prima para suas fábricas. As fábricas de tecidos ficavam em Alagoas e na Bahia, onde eram utilizados 200 teares da companhia britânica Henry Rogers \& Cons. No total, eram empregados cerca de 400 operários. O diretor da fábrica na Bahia, Fernando Peixoto, havia sido por algum tempo diretor da Companhia de Seguros Aliança. ${ }^{415}$

Em Pernambuco, na década de 1910, funcionava a Fonseca Irmãos \& Cia., importante casa importadora de cimento, madeira, querosene e banha, produtos vindos de Nova York, Inglaterra, Alemanha e Buenos Aires. Como em tantos outros casos no Brasil,

\footnotetext{
${ }^{411}$ BRASIL, Correio Paulistano, Arquivo Público do Estado de São Paulo, 21 de julho de 1909, p. 05.

412 Ibidem, p. 04.

413 Ibidem, p. 04.

${ }^{414}$ SCHOMPRÉ, Émile Quoniam. La Bourse de São Paulo. Typographia Casa Garrauz. São Paulo, 1911, p. 294.

${ }^{415}$ Ibidem, p. 888.
} 
a casa importadora se engajou ela própria no setor manufatureiro, e passou a produzir sabão e velas em edifício vizinho ao seu escritório. ${ }^{416}$

A fábrica de sabão e velas era de grandes proporções, empregava cerca de 100 operários, contava com máquinas e aparelhos ingleses e duas caldeiras a vapor, e exportava sua produção para estados vizinhos do Nordeste. O fundador da casa, Corbiniano d'Aquino Fonseca, era presidente da Associação Comercial de Pernambuco e um dos fundadores da Companhia de Seguros Thetis. ${ }^{417}$

A década de 1910 foi a mais próspera para a antiga firma exportadora B. R. de Azevedo, fundada em 1852 em Curitiba. A casa exportava sobretudo mate para a Argentina, Uruguai e Chile, e possuía um engenho com maquinismo aperfeiçoado; as barricas para o acondicionamento do mate não eram importadas como de costume, mas feitas na serraria do próprio engenho, e no total eram empregados cerca de 60 operários. As principais marcas do mate produzidos pela B. R. de Azevedo eram A. R. Santos, Blanca, Loro, El Toro, Olivia e Iguassí, e a firma era também agente da Companhia de Seguros Alliance, de Londres. ${ }^{418}$

Outro exemplo da expansão de casas industriais no período é a Companhia Chimica Industrial de São Paulo, fundada em agosto de 1909 com o capital de Rs 100:000\$000, quatro anos depois aumentado para Rs 400:000\$000. O desenvolvimento fabril paulista na primeira década do século $\mathrm{XX}$ estimulou a formação de indústrias subsidiárias, dentre elas a de produtos químicos, sobretudo do ácido sulfúrico e clorídrico, elementos indispensáveis em vários tipos de manufaturas e à época bastante difíceis de serem importados. A fabricação de produtos químicos inseria-se como indústria subsidiária cuja ascensão no século XX era notável; em 1913, a Companhia Chimica Industrial de São Paulo contava com 290 operários, laboratório, almoxarifado e tipografia. Possuíam duas grandes caldeiras dos fabricantes britânicos Wolf \& Marshall Sons, de quem havia igualmente importado alambiques a vapor e a fogo direto, máquinas para fabricar comprimidos, água oxigenada, magnésia fluida, pó-de-arroz, polvilhos alcoolatos, perfumarias diversas, ácido fênico, cresil, creolina, benzina. ${ }^{419}$

Os operários da Companhia Chimica Industrial eram segurados pela acima referida Companhia Cruzeiro do Sul; as fábricas e suas dependências, por sua vez, tinham

\footnotetext{
${ }^{416}$ SCHOMPRÉ, Émile Quoniam. La Bourse de São Paulo. Typographia Casa Garrauz. São Paulo, 1911, p. 945

${ }^{417}$ Ibidem, p. 945

${ }^{418}$ Ibidem, p. 945

${ }^{419}$ Ibidem, p. 965
} 
seguros da Equitativa Brasileira, Indemnisadora e Companhia Paulista de Seguros. A Chimica Industrial referia-se a si mesma como "de grande prosperidade e com ótima situação financeira, estando em ótimas relações fiduciárias com os principais estabelecimentos de crédito, quer nacionais, quer estrangeiros." ${ }^{420}$

Também em 1909 foi fundada em São Paulo outra fábrica de produtos químicos e farmacêuticos, a L. Queiroz \& Comp. Em janeiro de 1910 a firma fazia emissão pública de debêntures pela imprensa; a subscrição era para um empréstimo de Rs 500:000\$000, dividido em 5.000 debêntures de Rs $100 \$ 000$ cada. O objetivo público da L. Queiroz era adquirir crédito para ampliar seu equipamento e maquinário de modo a "supprir o crescente consumo de seus productos", que respondiam à demanda de regiões com centros industriais em expansão, como São Paulo, Paraná, Santa Catarina e Rio Grande do Sul. ${ }^{421}$ Afim de convencer os investidores a comprarem seus títulos, a companhia fazia referência à necessidade de indústrias subsidiárias nacionais "para que uma bôa parte dos lucros oriundos dessa nascente indústria não emigrasse para o estrangeiro" devido a importação de insumos. ${ }^{422}$

Como garantia ao empréstimo via debêntures, foram citados os ativos da firma, compostos sobretudo por máquinas, caldeiras, alambiques e moinhos, além de terrenos e edifícios na cidade de São Paulo. A L. Queiroz possuía um terreno na rua Bernardino de Campos, sobre o qual pretendia construir uma de suas principais usinas e aproveitar o fato do espaço ser limitado em uma de suas laterais pela linha férrea da São Paulo Railway. ${ }^{423}$ A fábrica, seus maquinismos, acessórios e mercadorias estavam segurados em Rs 200:000\$000, divididos em quatro apólices de Rs 50:000\$000 em distintas companhias de seguros, as quais a Companhia União Commercial Varegista, Companhia Previdente, Companhia Paulista e Companhia Alliança da Bahia. ${ }^{424}$

Como dito acima, consideramos que a existência de apólices que seguravam estabelecimentos fabris inteiros ou mesmo parte de seu maquinário constituiu-se como importante fator de estímulo ao risco e de garantia às perdas. Por meio da consolidação de um setor de seguros nacional, aos poucos cresciam as possibilidades de contrapartidas

\footnotetext{
${ }^{420}$ BRASIL, Impressões do Brazil no século XX. Lloyd's Greater Britain Publishing Company, Arquivo Municipal de Cubatão, 1913, p. 688

${ }^{421}$ BRASIL, Correio Paulistano, Arquivo Público do Estado de São Paulo, 20 de janeiro de 1910, p. 08.

${ }^{422}$ Ibidem, p. 08.

${ }^{423}$ Ibidem, p .08

${ }^{424}$ Ibidem, p. 08 
às tomadas de risco, o que por sua vez estimulava a expansão dos negócios. A consequência era uma maior acumulação de capital por parte das manufaturas brasileiras.

\subsection{As companhias de seguros e o Convênio de Taubaté}

A partir dos anos de 1902 e 1903, constatamos uma preocupação por parte do governo brasileiro no que diz respeito ao excesso de café colhido na região Sudeste e sua subsequente desvalorização. Em 1903, os preços tinham baixado a 30 francos por 50 quilos; calculando o franco de 1903 a 27 d. por mil réis, tem-se que 50 quilos equivaliam a Rs 1.850. A título de comparação, no período áureo do café, entre 1886 e 1896, os preços do café oscilavam de 70 a 132 francos por 50 quilos (Rs 2.500 a 4.800) no porto de Havre, França. ${ }^{425}$

No Relatório do Ministério da Fazenda do ano de 1903, por exemplo, encontramos a seguinte passagem:

(...) discutem-se muito no Brasil as medidas que convém adotar para valorizar o café, afim de que a agricultura possa tirar justa remuneração do seu trabalho e dos capitaes nela empregados. Muitos projectos tem sido lembrados; o único acceitavel, porém, será aquelle que tiver por fim a diminuição da produção e o augmento sensível do consumo, que, como se verá, não obstante a grande baixa dos preços e as facilidades offerecidas pelos stocks accumulados em todos os principaes centros, mui pequeno accrescimo teve e não está de modo algum em relação com a producção brasileira. ${ }^{426}$

\section{Ainda no mesmo Relatório:}

Em resumo, a situação está longe de ser animadora e de tudo quanto se tem escripto sobre o assumpto um unico ponto é indiscutivel: a causa da crise que atravessamos é o excesso de producção. Tomadas as medidas que todos, de comum acordo, julgam necessarias, sanar-se-há certamente o mal; mas que nossos agricultores se lembrem que o café não é o único producto que pode subir do nosso solo. ${ }^{427}$

${ }^{425}$ BRASIL, Impressões do Brazil no século XX. Lloyd's Greater Britain Publishing Company, Arquivo Municipal de Cubatão, 1913, p. 348.

${ }^{426}$ BRASIL, Relatório do Ministério da Fazenda, 1903, p. 167.

${ }^{427}$ BRASIL, Relatório do Ministério da Fazenda, 1903, p. 160 
Estas expressões de alarme são um prenúncio da preocupação com o preço do café, condição que acompanharia para sempre os cafeicultores brasileiros a partir de então e que culminaria em 1906 com a formulação do Convênio de Taubaté. Antes disso, outras propostas para impedir a queda do preço haviam sido avaliadas. A partir de 01 de janeiro de 1903, a lei orçamentária paulista tentou conter a expansão dos cafeeiros a partir da cobrança de impostos proibitivos de Rs 2:000\$000 por 2,42 ares ou fração superior a 1,21 ares de terras ocupadas por plantações de café (sendo 1 are o equivalente a $100 \mathrm{~m}^{2}$ ). ${ }^{428}$

Ao final do ano de 1903, o Retrospecto do Jornal do Commercio mostrava-se preocupado com a situação do produtor de café brasileiro, cuja mercadoria perdia valor no mercado, mas os custos para sua manutenção, como seguros e crédito, permaneciam iguais. Nas palavras do jornal:

(...) é claro e intuitivo que o detentor de uma enorme quantidade de qualquer genero, que dia a dia vai encarecendo de preço com as despezas forçadas de seguros, aramazenagens e juros de capital empatado, só póde ter um interesse, no caso perfeitamente identico ao do productor, o de valorizal-o, mas nunca o de diminuir-lhe o valor. ${ }^{429}$

É sabido que nesse contexto de superabundância do café, países com elevado nível de importação do produto mostravam-se interessados em que a baixa persistisse. Os EUA, à época maiores consumidores de café do mundo, já no ano de 1902 promoveram uma Conferência Internacional em Nova York para tratar do tema, reunião que rapidamente chamou a atenção do Ministério da Fazenda brasileiro. ${ }^{430}$

O projeto mais radical para levar a cabo a valorização dos grãos, no entanto, veio em 1906, com o Convênio de Taubaté. Para de fato compreendermos as origens desse plano, cabe tratarmos da inelasticidade demanda-preço do referido produto. Na prática, essa inelasticidade significava pouca sensibilidade dos consumidores em relação aos altos e baixos dos preços da mercadoria, pois se o valor do café aumentasse, a demanda permaneceria a mesma. Por outro lado, em momentos de queda dos preços, não se verificava um aumento do consumo, o que invariavelmente produzia estoques excedentes. Considerando a posição quase monopolista que o café brasileiro possuía no mercado

\footnotetext{
${ }^{428}$ FAUSTO, Boris, "Expansão do café e política cafeeira", História Geral da civilização brasileira, v. I, t. III, 6 ${ }^{a}$ edição, Rio de Janeiro: Bertrand Brasil, 1997, p. 209.

${ }^{429}$ BRASIL, Retrospecto do Jornal do Commercio. Rio de Janeiro: Typographia do Jornal do Commercio de Rodrigues, 1903, p. 79.

${ }^{430}$ BRASIL, Relatório do Ministério da Fazenda, 1903, p. 195.
} 
mundial, era óbvio que o aumento da oferta teria um impacto bastante negativo sobre as receitas do produto. ${ }^{431}$

Foi a posição monopolista do café brasileiro, no entanto, que deu viabilidade ao projeto de valorização. Por controlarem quase que inteiramente a oferta cafeeira em nível mundial, os fazendeiros do Sudeste viram-se capazes de determinar o preço das sacas via compra e armazenagem do excedente. Conforme surgiam as expectativas de uma super safra a ser colhida no ano de 1906, os anseios em relação à queda do preço dos grãos tornavam-se mais palpáveis; as possibilidades de restrição da oferta para controle dos preços, no entanto, só seriam possíveis se contassem com algum financiamento da compra dos estoques. ${ }^{432}$ Considerando a escassa poupança brasileira à época, tem-se que o sistema bancário doméstico não conseguiria conceder o crédito necessário; a solução encontrada foi pedir financiamento externo. ${ }^{433}$

A partir daí formou-se o Convênio de Taubaté, um acordo entre os principais estados produtores de café da época, Minas Gerais, São Paulo e Rio de Janeiro, cujo objetivo era garantir o plano de valorização via crédito estrangeiro. Frente à demanda dos cafeicultores do Sudeste, o governo federal surpreendentemente negou-se a conceder garantia aos empréstimos forâneos. ${ }^{434} \mathrm{O}$ plano foi então sustentado a partir do crédito dado por grandes importadores estrangeiros e por garantias do Estado de São Paulo; a realidade do acordo inicial do Convênio não prosperou, e o projeto posto em prática foi bastante distinto daquele acordado entre os governadores dos três Estados. Por não terem disposto de ajuda federal, aos poucos Minas Gerais e Rio de Janeiro se retiraram do plano, deixando-o todo sob os encargos de São Paulo. ${ }^{435}$

Junto do plano de compra do excedente do café, o Convênio propôs a criação de uma Caixa de Conversão, isto é, um caixa que fixasse a taxa cambial em mil réis a partir de depósitos em ouro. A partir das reservas que pudesse acumular o Brasil estaria apto a estabilizar sua taxa de câmbio. Segundo Thomas Holloway:

\footnotetext{
${ }^{431}$ FRITSCH, Winston, obra citada, p. 38.

${ }^{432}$ Após a colheita de 1901-02, o estoque mundial de café subiu a 11.305.000 sacas; para o ano de 1906, no entanto, eram previstas cerca de 17.000.000 sacas a serem colhidas, o que representaria a ruína dos fazendeiros. BRASIL, Impressões do Brazil no século XX. Lloyd's Greater Britain Publishing Company, Arquivo Municipal de Cubatão, 1913, p. 350.

${ }^{433}$ FRITSCH, Winston, obra citada, p. 39

${ }^{434}$ Ibidem, p. 39

${ }^{435}$ HOLLOWAY, Thomas, obra citada, p. 65.
} 
Pode-se dizer que os políticos por detrás da cláusula da Caixa de Conversão no Convênio de Taubaté entenderam que para o plano de valorização do café ser bem-sucedido e que para o planejamento a longo prazo contra as flutuações de preços prosperar fazia-se necessário estabilizar a cotação da moeda. ${ }^{436}$

Após a formulação da Caixa de Conversão, cuja existência pressupunha a aprovação do Congresso, o câmbio brasileiro de fato manteve-se estável até o início da Primeira Guerra Mundial. Em 1907, um ano após a entrada em vigor das novas medidas, encontramos as seguintes afirmações no Relatório do Ministério da Fazenda a respeito do câmbio:

Na história financeira do Brasil, o ano de 1907 ficará assignalado como o primeiro em que a estabilidade cambial foi inflexivelmente mantida, chegando nos últimos tempos à fixidez absoluta que ainda hoje perdura, apezar do momento que passamos, caracterizado normalmente pelo enfraquecimento do mercado

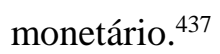

Ao explicar o sucesso da estabilidade do câmbio a partir de 1906, David Campista, Ministro da Fazenda do governo de Afonso Pena, afirmou:

Houve indubitavelmente um elemento novo, cujo concurso poderoso não pode ser desconhecido, e esse foi a Caixa de Conversão. É inútil insistir na demonstração tantas vezes e tão claramente feita da acção que exerce a Caixa de Conversão na estabilidade do câmbio. Funciona como aparelho automatico, dizia eu no relatório anterior, recebendo ouro na época em que é mais abundante e lançando-o ao mercado quando se faz mais necessário. Quando outra influencia não tivesse esse instituto senão a de impedir as altas cambiais ephemeras, que o Banco do Brasil não pudera anteriormente evitar, bastaria essa influencia para dar à Caixa de Conversão a parte decisiva que lhe confere na estabilidade do câmbio. ${ }^{438}$

A partir da entrada em vigor do Convênio de Taubaté e da Caixa de Conversão, instituições preocupadas com a estrutura financeira nacional, constatamos no Brasil um período de relativa tranquilidade econômica e solidez dos preços do café. A despeito da crise de 1907, da qual trataremos mais a frente, até o início da Primeira Guerra Mundial o país contou com boa inserção no mercado estrangeiro, e desde o ano de 1906 assistiu-

\footnotetext{
${ }^{436}$ Ibidem, p. 66

${ }^{437}$ BRASIL, Relatório do Ministério da Fazenda, 1907, Introdução, p. 10

${ }^{438}$ BRASIL, Relatório do Ministério da Fazenda, 1907, Introdução, p. 15. 
se à uma ampliação de investimentos estrangeiros e nacionais. A institucionalização do programa de valorização do café, tornado permanente, ampliou os fluxos de comércio estrangeiro e a normalização do câmbio, ancorado nas reservas em ouro da Caixa de Conversão; daí a garantia de estabilidade às transações comerciais e financeiras.

Todas essas variáveis tiveram impacto direto no funcionamento das companhias de seguros no Brasil, e de fato a estabilidade pós-1906 proporcionou a criação de novas companhias nacionais e a entrada de novas estrangeiras.

No que diz respeito às companhias de seguro de vida funcionando no Brasil no ano de 1906, um levantamento com importantes valores referentes às suas reservas técnicas, número de seguros realizados, receita de prêmios e capital empregado em apólices do Tesouro Federal foi publicado pelo Jornal do Commercio em 18 de janeiro de 1908:

TABELA 11 - Dados financeiros das companhias e seguros, 1906 (valores em mil-réis)

\begin{tabular}{|l|l|}
\hline Reservas Técnicas & $27.531: 754 \$ 520$ \\
\hline Seguros realizados & $57.021: 420 \$ 980$ \\
\hline Receita de prêmios & $11.899: 768 \$ 602$ \\
\hline $\begin{array}{l}\text { Capital empregado em apólices do } \\
\text { Tesouro Federal }\end{array}$ & $5.981: 200 \$ 000$ \\
\hline
\end{tabular}

BRASIL, Correio Paulistano, 01 de março de 1908, p. 05. Dados referentes à 1906 originalmente publicados no Jornal do Commerico em 18/01/1908.

Ainda a respeito da influência da estabilidade pós Convênio de Taubaté sobre a atuação das companhias de seguros, temos que relação entre estas últimas e o câmbio variava conforme o produto segurado; se nos detivermos na exportação de café, já sabemos que nos momentos de queda do preço desse produto no mercado externo era necessário desvalorizar a moeda para torná-lo mais competitivo. Companhias de seguro inseridas no comércio de navegação responsáveis pelo produto naturalmente apoiariam a desvalorização cambial. Por outro lado, aquelas que segurassem casas importadoras seriam beneficiadas pela valorização monetária, cujo efeito mais imediato era a ampliação da capacidade de importar da moeda. As seguradoras que estivessem inseridas no mercado financeiro veriam vantagens em taxas de juros e câmbio altas, que permitissem 
um bom retorno do capital que procurasse render; o câmbio alto também agradava às companhias de seguro estrangeiras, habituadas à remeterem suas rendas para suas sedes.

A posição das seguradoras frente às flutuações do câmbio, portanto, variava conforme a inserção econômica de cada sociedade; da mesma forma que o capital cafeeiro, conforme se complexificava, adquiria distintas expectativas frente ao câmbio, as companhias de seguros, inseridas em contextos mercantis, comerciais e financeiros, também possuíam diferentes preferências no que diz respeito ao valor da moeda.

Dentre as companhias de seguros, nacionais e estrangeiras, que se formaram durante o contexto de estabilidade e abundância de capital estrangeiro pós 1906, citaremos alguns casos mais emblemáticos.

Em 1906 foi fundada a Companhia Paulista de Seguros Marítimos, Terrestres e de Vida, administrada por “considerados negociantes da praça de São Paulo e de Santos”. Já no ano de 1906 possuía agências em São Paulo, Santos e em Campinas, e seu alto capital de RS 2.000:000\$000 era dividido em 10.000 ações no valor de Rs 200\$000 cada. Durante o ano de 1906 suas operações aumentaram continuamente, acompanhando a estabilização da complicada condição do café no Brasil. O boom de transações econômicas que marcou o ano de 1906, pós valorização do café, levou a um total de Rs 22.172:69\$000 em operações, tido como um valor "considerável” pela imprensa, "demonstrando deste modo a confiança que a Paulista de Seguros desperta no público". 439

As indenizações de segurados naquele ano foram no valor de Rs 188:412\$550, e parte do seu capital realizado, no total de Rs 800:000\$000, estava empregado em 800 ações da Companhia Paulista de Estradas de Ferro, 300 ações da Mogyana, 200 apólices da dívida pública federal e 200 apólices da dívida do Estado de São Paulo. ${ }^{440}$ Em julho de 1909 a seguradora permanecia como acionista das estradas de ferro Paulista e Mogyana, tendo aumentado sua participação para 1000 ações de ambas as sociedades, num total de Rs 265:820\$000; continuava financiando o Estado de São Paulo, sendo proprietária de 857 apólices de sua dívida, num total de Rs 228:000\$000. ${ }^{441}$

A partir dos dados desse mesmo balanço referente a julho de 1909, temos que a Companhia Paulista de Seguros possuía Rs 27:040\$000 em juros e dividendos a serem

\footnotetext{
${ }^{439}$ BRASIL, Correio Paulistano, Arquivo Público do Estado de São Paulo, 30 de novembro de 1906, p. 05 .

440 BRASIL, Correio Paulistano, Arquivo Público do Estado de São Paulo, 30 de novembro de 1906, p. 05.

${ }^{441}$ SCHOMPRÉ, Émile Quoniam. La Bourse de São Paulo. Typographia Casa Garrauz. São Paulo, 1911, p. 90.
} 
recebidos, além de Rs 66:801\$015 em títulos do Banco de São Paulo. Considerando que nesse período a companhia contava com o total de Rs 1.200:000\$000 em ações próprias compradas por acionistas, e outros Rs 400:000\$000 fruto da propriedade de apólices não especificadas, temos que parte muito expressiva do seu ativo, cerca de $73 \%$, era composta por títulos financeiros; o valor advindo de prêmios pagos por proprietários de apólices no referido balanço era de apenas Rs 18:045\$180, isto é, menos de $1 \%$ do total dos ativos. ${ }^{442}$

Os dados de seu balanço para o ano de 1907 informam cerca de Rs 40:000\$000 a serem distribuídos em dividendos; a título de comparação, o Banco do Commercio e Industria de São Paulo, naquele mesmo ano, distribuiu também em dividendos cerca de Rs 800:000\$000. ${ }^{443}$ Os números demonstram maior visibilidade e credibilidade da instituição bancária do que a seguradora na Bolsa de Valores de São Paulo, o que de maneira geral pode ser comprovado em outros momentos. A Paulista de Seguros recebia menos em dividendos do que distribuía: naquele mesmo ano recebera Rs 15:400\$000 dos títulos que possuía sobre outras sociedades. ${ }^{444}$ Suas ações eram cotadas em Rs $86 \$ 000$; novamente a título de comparação, temos que a Companhia Industrial de São Paulo tinha suas ações avaliadas em Rs 105\$000, a Mogyana em Rs 295\$000, e a Paulista de Estradas de Ferro em Rs $300 \$ 000 .{ }^{445}$

Em maio de 1909, uma onda de rejeição às ações da Companhia Paulista de Estradas de Ferro trouxe excessiva calmaria ao mercado de títulos da Bolsa de Valores de São Paulo, que teve a velocidade de suas transações bastante reduzida. O menor volume de compras dos papéis da estrada de ferro enfraqueceu os títulos na Bolsa e os negócios foram rareando. Nesse momento de relativa paralisação das atividades da Bolsa as ações da Companhia Paulista de Seguros passaram a valer cerca de Rs 97 cada; o Banco de São Paulo possuía ações no valor de Rs 125 cada; a Companhia Mogyana, cujos títulos à época estavam dentre os mais negociados, teve ações vendidas por Rs 325; e a Estrada de Ferro de Araraquara vendeu seus papéis por Rs 95.446

No ano de 1914 a Companhia Paulista de Seguros permanecia envolvida na compra de títulos de outras empresas. O valor investido em títulos privados e públicos, alguns anos depois, era razoavelmente maior; cerca de Rs 2.600:000\$000 estavam investidos em

\footnotetext{
442 BRASIL, Correio Paulistano, Arquivo Público do Estado de São Paulo, 25 de julho de 1909, p. 06.

${ }^{443}$ BRASIL, Correio Paulistano, Arquivo Público do Estado de São Paulo, 12 de fevereiro de 1907, p. 02

444 Ibidem, p. 02

445 Ibidem, p. 02

${ }^{446}$ BRASIL, Correio Paulistano, Arquivo Público do Estado de São Paulo, 09 de maio de 1909, p. 04.
} 
apólices da União e do Estado de São Paulo, em ações das Estradas de Ferro Paulista e Mogiana, e em dinheiro depositado no Banco de São Paulo. ${ }^{447}$

Ainda a respeito do desempenho das companhias de seguros em meio à nova conjuntura de estabilidade cambial e dos preços altos do café, apresentaremos uma tabela formulada pela A Equitativa, companhia de seguros de vida de 1878, em que a própria seguradora apresenta uma trajetória ascendente entre os anos de 1897 e 1906.

FIGURA 1

Anúncio da Companhia de Seguros Equitativa no jornal Correio Paulistano

${ }^{447}$ BRASIL, Correio Paulistano, Arquivo Público do Estado de São Paulo, 12 de fevereiro de 1907, p. 02 


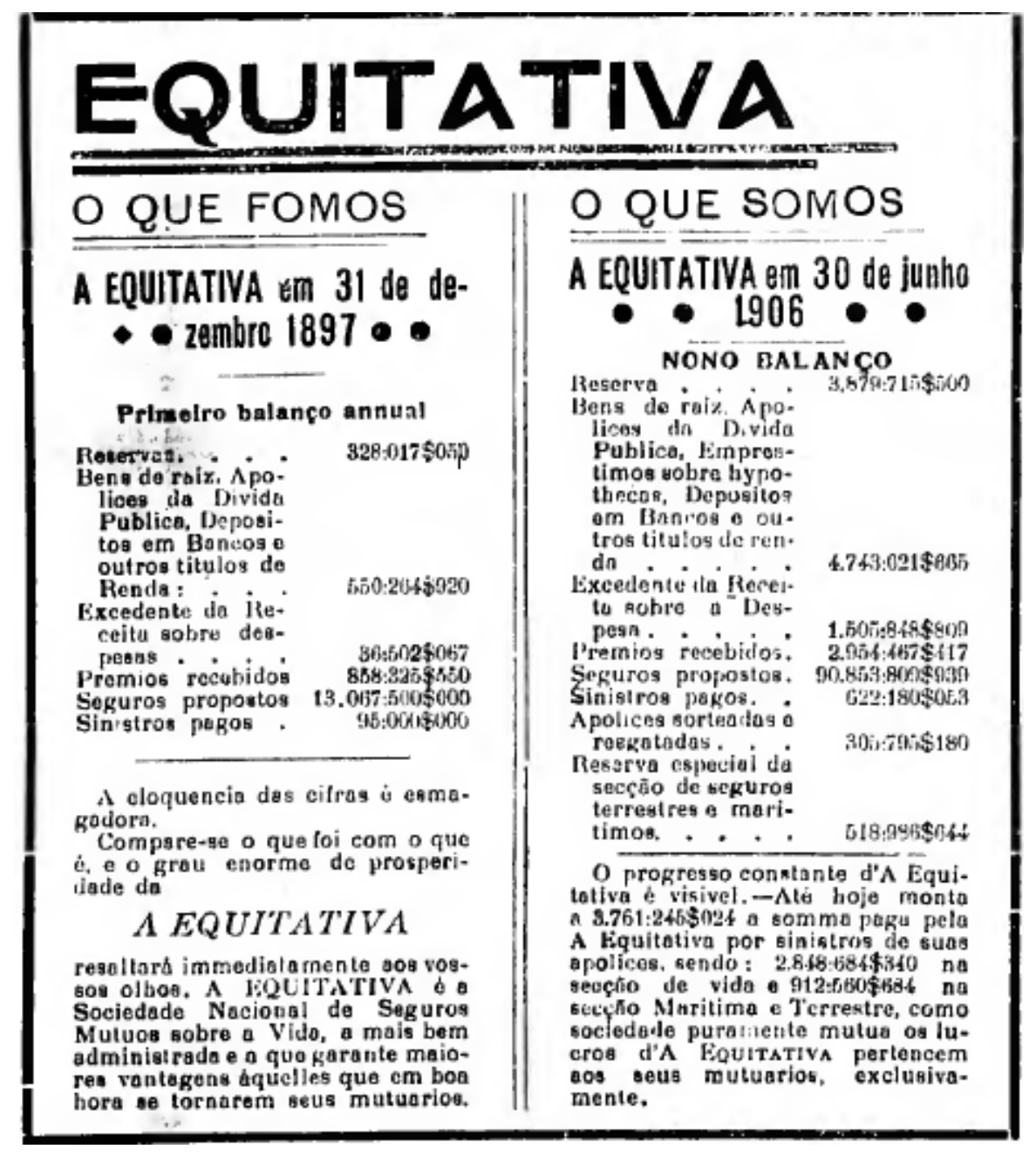

Fonte: BRASIL, Correio Paulistano, Arquivo Estadual de São Paulo, 14 de dezembro de 1906, p. 02 .

Na comparação entre o balanço anual de 1897 e o publicado no Correio Paulistano cerca de onze meses depois, notamos o aumento da reserva, isto é, da poupança líquida da companhia, após serem descontadas suas obrigações de pagamento. Além disso há um expressivo aumento de Rs 4.192:916\$745 no seu patrimônio, formado por bens de raiz, títulos da dívida pública e depósitos em bancos. A grande ampliação nos valores de prêmios demonstra o aumento na quantidade de transações, e mais gastos com sinistros representam ocorrências de acidentes que demandaram ressarcimento imediato da $\mathrm{A}$ Equitativa.

Outra seguradora importante da época teve seu desempenho melhorado a partir de 1906, no mesmo contexto de estabilidade econômica e cambial já referido. Abaixo está um quadro comparativo publicado pela Sul América em 1907, também no Correio Paulistano: 


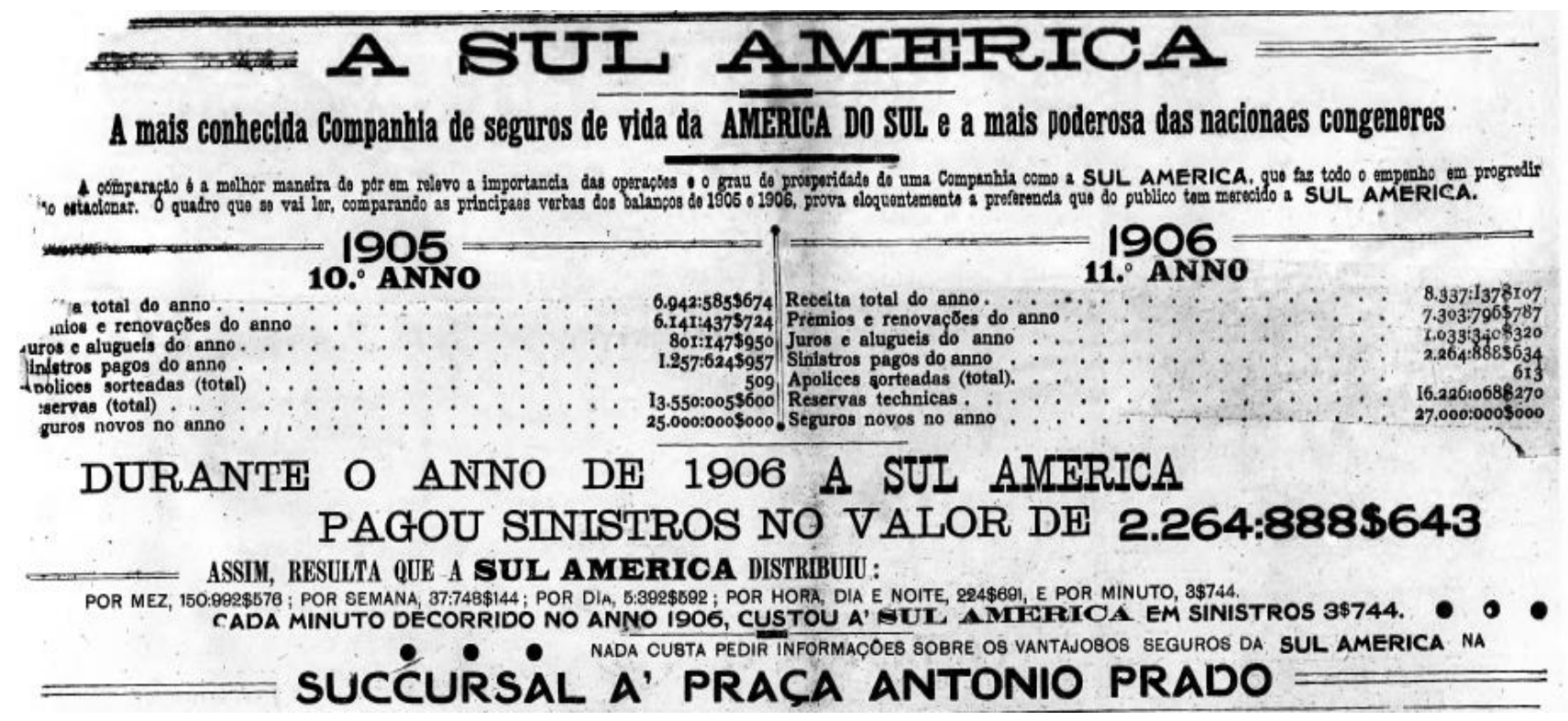

Fonte: BRASIL, Correio Paulistano, Arquivo do Estado de São Paulo, 01 de setembro de 1907, p.05.

A partir desta tabela temos que entre 1906 e 1907 a receita total da companhia cresceu em cerca de Rs 1.394:551\$433, o valor de seus prêmios em Rs 1.162:359\$063 e o valor com os seguros novos vendidos, em Rs 2.000:000\$000. O alto valor gasto com pagamentos de sinistros, obviamente, representa elevadas ocorrências de acidentes. No entanto podemos interpretar recorrentes pagamentos de sinistros como decorrência de um elevado número de contratos, o que por sua vez denotaria uma atmosfera propícia para a compra de apólices de seguros. Abaixo apresentamos uma tabela com os dados referentes às reservas, os ativos, o total de garantias, prêmios recebidos, os seguros em vigor e os novos seguros das principais companhias de seguros funcionando no Brasil no contexto pós Convênio de Taubaté. Todos os dados foram retirados do ano de 1907.

TABELA 12 - Reservas, ativos, garantias, prêmios e número de novos seguros em vigor no contexto pós Convênio de Taubaté, 1907 (valores em mil-réis)

\begin{tabular}{|l|l|l|l|l|l|}
\hline Sul América & $\begin{array}{l}\text { Caixa Geral } \\
\text { das Famílias }\end{array}$ & $\begin{array}{l}\text { Equitativa do } \\
\text { Brasil }\end{array}$ & $\begin{array}{l}\text { Garantia da } \\
\text { Amazônia }\end{array}$ & $\begin{array}{l}\text { New York } \\
\text { Life } \\
\text { Insurance Co. }\end{array}$ \\
\hline
\end{tabular}




\begin{tabular}{|l|l|l|l|l|l|}
\hline & & & & & $\begin{array}{l}\text { (seção } \\
\text { Brasil) }\end{array}$ \\
\hline Reservas & $13.550: 005 \$ 600$ & $608: 422 \$ 000$ & $3.031: 063 \$ 600$ & $5.441: 831 \$ 692$ & $663: 842 \$ 000$ \\
\hline Ativos & $15.956: 261 \$ 781$ & $794: 918 \$ 977$ & $3.780: 679 \$ 405$ & $10.144: 345 \$ 597$ & \\
\hline Garantia & $14.825: 267 \$ 247$ & $77: 849 \$ 038$ & $3.576: 400 \$ 810$ & $9.069: 633 \$ 910$ & $663: 842 \$ 000$ \\
\hline $\begin{array}{l}\text { Prêmios } \\
\text { recebidos }\end{array}$ & $6.141: 437 \$ 724$ & $346.530 \$ 060$ & $1.783: 308 \$ 997$ & $1.841: 110 \$ 390$ & $969.261 \$ 868$ \\
\hline $\begin{array}{l}\text { Seguros } \\
\text { em vigor }\end{array}$ & $107.369: 806 \$ 600$ & $8.948: 683 \$ 000$ & $38.736: 047 \$ 040$ & - & $12.959: 045 \$ 000$ \\
\hline $\begin{array}{l}\text { Novos } \\
\text { seguros }\end{array}$ & $25.000: 000 \$ 000$ & $1.207: 000 \$ 000$ & $16.924: 504 \$ 200$ & & \\
\hline
\end{tabular}

Fonte: BRASIL, Correio Paulistano, Arquivo Público do Estado de São Paulo. 20 de janeiro de 1907, p. 04.

Sabemos que em 1907 os valores das reservas das companhias de seguro nacionais, a partir das quais era possível investir em instituições financeiras ou em sociedades produtivas, valorizaram-se através da estabilização do câmbio. Considerando que o total das reservas de todas as companhias de seguro funcionando no Brasil no ano de 1907 era de Rs 24.885:164\$892 448 , verificamos que as companhias estrangeiras de fato remetiam a maior parte de seu capital para seus países de origem.

Naquele mesmo ano de 1907 foi inaugurada em São Paulo a Companhia de Seguros de Vida Mercúrio, cujo propósito declarado desde seu início era a venda de seguros populares, cujos preços variavam de Rs $500 \$ 000$ até Rs 4:000\$000. ${ }^{449}$ Nos registros encontrados, sabemos que a companhia também realizava seguros mais caros, como de uma loja de ferragens e louças na cidade de São Paulo, segurada em Rs 35:000\$000. ${ }^{450}$ Seu principal agente era Rodolpho Guimarães, que além de representar companhias de seguros encarregava-se de despachos na Alfândega de Santos e de transporte via cabotagem. Segundo seu próprio anúncio no Correio Paulistano em abril de 1904, Rodolpho Guimarães era o mais importante agente da Companhia de Seguros Marítimos e Terrestre Mercurio, além de depositário da manteiga mineira da marca Veado e dos produtos vindos das fazendas da "família Pirassunuga"; aceitava receber cargas para

\footnotetext{
${ }^{448}$ BRASIL, Correio Paulistano, Arquivo Público do Estado de São Paulo, 12 de fevereiro de 1907, p. 02 ${ }^{449}$ BRASIL, Correio Paulistano, Arquivo do Estado de São Paulo, 21 de abril de 1907, p. 05.

${ }^{450}$ BRASIL, Correio Paulistano, Arquivo do Estado de São Paulo, 12 de junho de 1904, p. 03.
} 
todos os portos da República e para todas as estradas de ferro paulistas, encarregando-se dos embarques e despachos. ${ }^{451}$

No que diz respeito aos gastos com seguros realizados por outras firmas, tivemos acesso sobretudo aos relatórios de bancos e a publicações do governo, cujos balanços nos apresentam a proporção dos gastos com companhias seguradoras. Citaremos o caso do Banco União de São Paulo, que em 1906 obteve a maior parte de seu lucro de juros sobre empréstimos ao comércio, sobre indústria e hipotecas. Em relação aos débitos, naquele ano o banco gastou 2,3\% de seus gastos totais com seguros; praticamente a mesma proporção era gasta com aluguéis; $4,2 \%$ iam para juros tomados pelo próprio banco, e $16,9 \%$ eram pagos em juros de letras hipotecárias. ${ }^{452}$

Em 1904, a Companhia Sul Paulista de Navegação e Mineração remeteu seus gastos à Inspetoria de Estrada de Ferro e Navegação, onde apresentava seu balanço entre ativos e débitos. Funcionando sobretudo na região do rio Juquiá desde 1903, a Navegação e Mineraçao realizava viagens com objetivos estritos de transporte, e no ano de 1904 havia transportado cerca de 592.800 toneladas de mercadorias e 67 toneladas de animais, obtendo assim um total de Rs 8:558\$090; no que diz respeito ao transporte de passageiros de primeira e segunda classe, havia faturado Rs 2:016\$420. Em relação aos gastos, naquele ano a companhia gastou 5,2\% de suas despesas totais com seguros. A maior parte das despesas vinha do tráfego das embarcações, que consumiam $54 \%$ do total; $4,1 \%$ eram despendidos com administração de oficinas e 4,6\% iam para manutenção de escritórios. 453

Envolvido na manutenção do serviço de navegação a vapor da província de São Paulo, em 1905 o governo gastou cerca de Rs 8:500:000 em seguros de material flutuante e Rs 15:500\$000 com os trechos entre Iguape e Juquiá. ${ }^{454}$ Em novembro do ano seguinte os gastos de manutenção dos principais prédios da prefeitura da cidade, ao lado dos impostos e aluguéis, totalizaram Rs 15:664:400.455

As crises de superprodução conhecidas pela economia cafeeira levaram à formação de instituições preocupadas com a consolidação do valor da moeda e do preço do café; a partir da consolidação das referidas instituições, apresentadas no presente item, verificamos a permanência das companhias de seguros em sua inserção financeira e

\footnotetext{
${ }^{451}$ BRASIL, Correio Paulistano, Arquivo Público do Estado de São Paulo, 25 de abril de 1904, p. 04

452 BRASIL, Correio Paulistano, Arquivo Público do Estado de São Paulo, 28 de abril de 1906, p. 04.

453 BRASIL, Correio Paulistano ,25 de abril de 1904, p.03.

${ }^{454}$ BRASIL, Correio Paulistano, 7 de dezembro de 1905, p. 03.

455 BRASIL, Correio Paulistano, 18 de novembro de 1906, p. 04
} 
mercantil na economia brasileira de então. Cabe agora compreendermos o contexto sob o qual funcionavam essas sociedades no momento anterior à Primeira Guerra

\subsection{A economia brasileira às vésperas da Primeira Guerra Mundial}

O período compreendido entre 1900 e 1913 foi definido por Winston Fritch como uma "década de ouro", momento em que a economia brasileira viveu um longo ciclo de crescimento com endividamento e as taxas do produto agregado passaram a ser de $4 \%$ ao ano. Nessa época o país contava com boa recepção do café no mercado externo, e até 1910 os preços da borracha cresciam, tornando a balança de pagamentos superavitária; além disso, a indústria conhecia um expressivo aumento na sua formação de capital. ${ }^{456}$

Apesar dos benefícios advindos com a consolidação do programa de valorização do café, a partir de 1910 o Brasil teve que lidar com manifestações contrárias ao plano por parte de seus principais mercados consumidores. Desde 1906 exportava-se café brasileiro sobretudo para os EUA, que naquele ano receberam 37,9\% dos grãos nacionais; em segundo lugar estava a Alemanha, com 21,8\%, e em terceiro a França, com 15,3\%. Santos era o principal porto de saída, exportando cerca de $72,8 \%$ do produto, e em segundo lugar estava o Rio de Janeiro, com 22,9\%. ${ }^{457}$

Fortemente interessados na baixa dos preços, particulares norte-americanos apresentaram aos tribunais locais a acusação de que o programa brasileiro incidia contra a Lei dos Trustes, a famosa Sherman Act de $1890 .{ }^{458}$ O tribunal decidiu que não. Segundo o Ministro da Fazenda Francisco Salles:

O plano de valorização nunca pretendeu, como, conjugando seus esforços, a especulação pretendia demonstrar, provocar a alta, retirando do mercado grandes quantidades de cafés, para que se produzisse notavel e premente desequilíbrio entre a oferta e procura. Proseguindo normalmente as suas operações, o plano da valorização, por sua natureza e fins bem diversos da organização dos trusts norte americanos, não podia de nenhum modo perturbar o livre commercio deste produto, nem tão pouco açambarcal-o e retel-o para a elevação exaggerada de seus preços. ${ }^{459}$

\footnotetext{
${ }^{456}$ FRITSCH, Winston, obra citada, p. 40.

${ }^{457}$ BRASIL, Relatório do Ministério da Fazenda, 1906, p. 89 e 91.

458 Segundo Winston Frisch: “ (...) em 1913, uma ação antitruste movida nos Estados Unidos contra os detentores da parcela dos estoques de café da supersafra de 1906, comprados com o aval do governo federal, ainda não vendidos e retidos em Nova York, obrigou à venda desses estoques, revertendo a tendência à alta dos preços."FRITSCH, Winston, obra citada, p. 40.

${ }^{459}$ BRASIL, Relatório Ministério da Fazenda, 1910/11, Seção Comércio Exterior, p. 168.
} 
Caso parecido ocorreu na França, onde um deputado local se manifestou contra o Convênio de Taubaté e a existência de estoques de café no Brasil, necessários para “amortecer" o preço; a acusação também foi levada à julgamento e o programa de valorização novamente foi considerado lícito. ${ }^{460}$

A reação brasileira às pressões externas fez-se através de uma razoável campanha nacionalista contra a presença do capital estrangeiro. $\mathrm{O}$ discurso contra as firmas vindas de fora agravava-se, e durante o ano de 1912 houve violenta polêmica na imprensa estimulada sobretudo pela ascensão do grupo Farquhar, grande capitalista inglês que, dentre outras tantas atividades levadas adiante no Brasil, participou do arrendamento da Estrada de Ferro Sorocabana em 1907. ${ }^{461}$ A partir da década de 1910 era possível constatar a partilha de direção das sociedades estrangeiras entre o capital externo e nomes nacionais; exemplo foi o próprio caso da Sorocabana, que após ser controlada por Farquhar contou com políticos paulistas em sua direção. ${ }^{462}$

O sentimento de revolta para com o capital estrangeiro continuava visível em 1910, mas já em 1913, quando a economia nacional mostrava sinais negativos, a reação nacionalista se dissipou. Sabemos que desde 1912 apareciam as primeiras preocupações no que diz respeito à deterioração do balanço de pagamentos nacional, já que os preços do café baixavam e os da borracha despencavam; em 1913, antes do início da Primeira Guerra, o Brasil já se encontrava em permanente crise de liquidez, agravada pelos maus resultados da balança de pagamentos e pela insistência do governo em permanecer fiel ao padrão ouro em meio à carestia de moeda (o que diminuía as reservas e as possibilidades de expansão monetária.) A consequência foi que a "economia entrou em profunda recessão bem antes do início das hostilidades na Europa", e o arrocho monetário fez necessário um novo funding loan junto a banqueiros estrangeiros em 1914. ${ }^{463}$

Após a entrada em vigor da Lei dos Trustes nos EUA e com a crise de 1907, algumas instituições financeiras brasileiras sofreram com interrupções de pagamentos e falta de capacidade de solvência. Como já nos referimos acima, encadeamentos de crises de pagamento já eram uma realidade no Brasil do final do século XIX, e as más condições

\footnotetext{
${ }^{460}$ Ibidem, p. 168

${ }^{461}$ SAES, Flavio, A grande empresa de serviços públicos na economia cafeeira, (1850-1930). São Paulo: Editora Hucitec, 1985, p. 186

462 Ibidem, p. 187. Segundo o autor “(...) este caso parece dar início a um tipo de procedimento das empresas estrangeiras, qual seja o de incluir em suas direções elementos brasileiros, ligados ou não à alta administração pública"

${ }^{463}$ FRITSCH, Winston, obra citada, p. 41. 
de uma instituição podiam facilmente afetar outra, sobretudo se fosse sua credora ou detentora de seus títulos.

Foi o que aconteceu com a Companhia de Seguros Mercúrio, que apenas um ano após sua fundação passou por profundas dificuldades no que diz respeito à suas reservas. Em março de 1908 o Banco União do Comercio, cuja diretoria era composta pelos mesmos membros diretores da Companhia Mercúrio e onde está última possuía depositada parte razoável de seu patrimônio, vai à falência, e a seguradora se vê incapacitada de pagar os cerca de Rs 400:000\$000 que devia aos segurados em forma de indenizações. A Mercúrio possuía ainda cerca de Rs 1.200:000\$000 de débitos com o referido banco e com o Banco do Brasil; quando da falência do União do Comércio, a Mercúrio é "arrastada de maneira deplorável”, segundo o Correio Paulistano. ${ }^{464}$ Nas palavras do jornal:

Não há dúvida alguma de que as instituições de crédito estão soffrendo uma depressão que a todos deve inquietar. Hontem ruia o Banco União do Commercio, causando prejuízos que ainda não são conhecidos na sua totalidade. Hoje, é a companhia Mercurio que se apresenta em um estado difficil de ser resolvido, e que vai talvez determinar a fallencia da companhia seguradora que mais se popularizou e que realizou transacções como nenhuma outra! ${ }^{465}$

Segundo o Correio Paulistano, a perspectiva de uma crise profunda na Companhia Mercurio já era sabida e esperada por outras instituições financeiras, sobretudo após um grande incêndio cujos sinistros foram assumidos pela seguradora:

Era sabido que junto ao Banco do Brasil eram feitas diligencias para evitar à Mercurio a crise em que se encontra, e fala-se no nome de um industrial como medianeiro que foi entre a companhia e o banco. Essas tentativas mallograram-se, o banco não pôde attendel-as e a situação da companhia aggravou-se com o grande incêndio da Bahia, que determinou prejuízos que nos dizem ser de Rs 150:000\$000. Em seguida à quebra do Banco União do Commercio, a Mercurio sentiu fundo abalo nas suas transacções, tendeo de despedir alguns empregados e reduzir despezas,

\footnotetext{
${ }^{464}$ BRASIL, Correio Paulistano, Arquivo Público do Estado de São Paulo, 27 de março de 1908, p. 03.

465 Ibidem, p. 03
} 
mas tudo isso era pouco para a gravidade da situação, para o qual o único remédio era a entrada de novo capital. ${ }^{466}$

A ameaça de clientes brasileiros partirem em direção a sociedades de seguros estrangeiras era colocada pelo jornal, que lamentava a perda de um mercado relativamente próspero para as companhias nacionais:

A situação desairosa da Mercurio vai talvez attingir as outras companhias nacionaes com desastrado reflexo, tendo fugido para as extrangeiras grande número de segurados que optavam pelas nossas companhias. ${ }^{467}$

Por fim, a publicação sugeria a intervenção da Inspetoria Geral de Seguros, responsável pela preservação dos Rs 200:000\$000 os quais as seguradoras depositavam quando obtinham suas cartas patentes de funcionamento, como forma de caução aos segurados; a quantia, no entanto, era pouco para fazer frente às indenizações da Mercúrio.

Já nos referimos ao boom da borracha, que teve seu fim em 1910, logo após o produto passar por um pico de preços no mercado externo. Com a concorrência da produção do Sudeste asiático, a borracha deixou de contribuir com a balança de pagamentos nacional e o Brasil voltou a ser bastante dependente do café. ${ }^{468}$ Com o início da guerra, o comércio exterior brasileiro foi afetado por uma interrupção do consumo no centro e uma subsequente estagnação da sua capacidade para importar; a recessão de 1913-1914 foi, portanto, agravada.

Rapidamente pioram as condições das companhias brasileiras e das estrangeiras funcionando no Brasil. O Relatório do Ministério da Fazenda de 1914 se refere a um aumento dos pedidos de autorização para funcionar de sociedades com pouca base sólida:

Em 1914, avolumou-se o numero de sociedades mutuas, sob todas as fórmas, que solicitaram autorização para funccionar. Sociedades, na sua maioria, fracas, sem base sólida de organização, comeccaram, já em fins desse anno, entrar em liquidação e fallencia, forçando o Governo a caçar-lhe a autorização concedida. Pode-se prever que dessa débacle só ficarão incólumes auquellas que realmente

\footnotetext{
${ }^{466}$ BRASIL, Correio Paulistano, Arquivo Público do Estado de São Paulo, 27 de março de 1908, p. 03 ${ }^{467}$ Ibidem, p. 03

${ }^{468}$ WEINSTEIN, Barbara, A Borracha na Amazônia: expansão e decadência (1850-1920). São Paulo: Hucitec/Edusp, 1993.
} 
tem elementos e garantias de existencia, fazendo-se, assim, a selecção necessaria. ${ }^{469}$

Verificamos o início da Primeira Guerra como um marco prejudicial para a economia, o que naturalmente prejudicou o funcionamento das companhias de navegação e de seguros, inteiramente dependentes dos fluxos do comércio mundial:

As operações de guerra marítima fizeram rarear os meios de vehiculação, elevaram os fretes e as taxas de seguros $\mathrm{O}$ desvio de vapores para outros transportes encontrou-nos insufficientemente apparelhados para acudir às necessidades com a frota mercante nacional. Desde logo, porém, procurou o Governo por intermédio do Lloyd brasileiro desenvolver a praça offerecida ao comércio exportador, mediante a criação de linhas novas e o fretamento de cargueiros. $^{470}$

Citaremos alguns exemplos das sociedades de seguros que funcionavam à essa época no Brasil. Em 1910, nos estertores do boom de exportação da borracha e com boas condições no mercado consumidor norte americano e europeu, é inaugurada a Weiss \& Schmid, importante firma curitibana fundada por alemães em 1910. Suas mercadorias eram importadas da América do Norte e da Alemanha, e seu estoque era formado por motores, dínamos, lustres, campainhas, telefones, e todo o material para instalações elétricas. Como constatamos desde a última década do século XIX, a presença de casas importadoras que se interessavam pela área de seguros permanecia recorrente.

A Weiss \& Schmid era sócia da firma alemã Mathias Bohn \& Cia, que atuava como correspondente de várias casas comerciais nacionais e européias em Paranaguá, no Paraná. Juntas, Weiss \& Schmid e Mathias Bohn \& Cia eram agentes de diversas companhias de navegação, como Hamburg-Amerika-Linie, Hamburg Südamerikanische Dampfschifffahrts-Gesellschaft, Norddeutscher Lloyd Bremen, Empresa de Navegação Espírito-Santo-Caravelas, Empresa L. Lorentzen do Pará, entre outras. ${ }^{471}$

Na seção de seguros, eram agentes de impressionante número de companhias: citamos as brasileiras Garantia do Amazônia, Alliança e Cruzeiro do Sul; a britânica Lloyd; Mannheimer Versicherungs-Gesellschaaft, de Mannheim; Norddeutsch, de Hamburgo; Compagnie d'Assurances Nationale Suisse, de Bâle; Compagnia Anonima di

\footnotetext{
${ }^{469}$ BRASIL, Relatório do Ministério da Fazenda, 1914, p. 228

${ }^{470}$ BRASIL, Relatório do Ministério da Fazenda, 1914, Introdução, p. 37.

${ }^{471}$ BRASIL, Relatório do Ministério da Fazenda, 1914, Introdução, p. 37.
} 
Assicurazione, de Gênova; e a The Union Marine Insurance Company, de Liverpool. Eram também comissários de avarias da companhia italiana de seguros e transportes Patria, de Nápoles. ${ }^{472}$

Outro exemplo de casa importadora que também trabalhava como agente de companhias de seguro era a firma Araújo \& Areosa, em funcionamento em Manaus desde 1910. A casa importava máquinas caseiras e grande quantidade de borracha, vendidas nas praças de Manaus e Belém. Eram agentes da Port of Pará, da Companhia de Navegação do Amazonas e de várias companhias de seguros marítimos e contrafogo. ${ }^{473}$

Na década de 1910 a Companhia Comércio e Navegação, fundada no Rio de Janeiro em setembro de 1905, conheceu um expressivo crescimento de suas operações e de seu lucro. Seus balanços semestrais mostram um aumento no volume dos negócios e nas fontes de receitas, sobretudo a partir de 1907. A Comércio e Navegação era proprietária de grande número de embarcações no porto do Rio de Janeiro e responsabilizava-se pela carga e descarga de vapores; mantinha no mesmo porto um serviço de reboques para navios nacionais ou estrangeiros de qualquer tonelagem. Durante seu funcionamento na primeira década do século XX brasileiro, a companhia nunca se ocupou com o transporte de passageiros, mantendo apenas linhas para serviço de carga para todos os portos nacionais. ${ }^{474}$

Em 1906, o valor do seu material flutuante era de Rs 2.563:000\$000, tendo atingido a cifra de Rs 4.199:972\$310 no ano de 1911; notamos em cinco anos um acréscimo de $60 \%$ sobre o total das aquisições. Outro aumento expressivo pôde ser verificado no valor das mercadorias e do material necessário para abastecer suas frotas, que de Rs 253:706\$315 em 1907 passou a Rs 577:271\$817 em 1911; o aumento dos referidos valores denota o desenvolvimento do setor e as necessidades cada vez maiores do serviço marítimo. ${ }^{475}$

Como em outros casos acima citados, a Companhia Comércio e Navegação decidiu, desde o início de suas operações, tomar o risco de seus vapores, criando na sua contabilidade uma conta especial para Fundo de Seguros. A ampliação no movimento da conta ao longo dos anos chama atenção. Em 1906, valia Rs 25:048\$580; em 1907, Rs

\footnotetext{
${ }^{472}$ BRASIL, Relatório do Ministério da Fazenda, 1914, Introdução, p. 37.

473 BRASIL, Impressões do Brazil no século XX. Lloyd's Greater Britain Publishing Company, Arquivo Municipal de Cubatão, 1913, p. 1006.

474 BRASIL, Impressões do Brazil no século XX. Lloyd's Greater Britain Publishing Company, Arquivo Municipal de Cubatão, 1913, p. 290

475 Ibidem, p. 290 
187:452\$070; em 1908, Rs 363:109\$310; em 1909, Rs 540:436\$890; em 1910, Rs 714:141\$830. Em 1911, a cifra do Fundo de Seguros diminuiu e chegou a Rs 379:413\$200, em consequência da perda dos dois paquetes carregados Parahyba e São Luiz. ${ }^{476}$

Constatamos que o início da Primeira Guerra legou à economia brasileira mudanças expressivas. As crises de liquidez já existiam antes do despontar do conflito, porém seu começo afetou ainda mais o fluxo dos pagamentos do comércio exterior; o governo federal foi obrigado a fechar a Caixa de Conversão, parar de seguir o padrão ouro e emitir moeda inconversível. É sabido ainda que a contração na produção manufatureira no centro e a iliquidez na periferia do período em questão dificultaram a capacidade de importação do Brasil, o que por sua vez criou dificuldades fiscais sérias ao país, cuja maior fonte tributária no âmbito federal vinha da taxação sobre os bens importados. ${ }^{477}$ No entanto, com as margens ociosas da indústria doméstica em meio à guerra e às restrições à importação, o Brasil conheceu um razoável impulso de sua produção manufatureira interna. $^{478}$

Podemos considerar que após os anos de política econômica restritiva no final da década de 1890, o país construiu mecanismos de defesa contra a instabilidade dos preços do café e do valor da moeda, bem como contra as descontinuidades na presença do capital estrangeiro; na primeira década do século XX, instituições como a Caixa de Conversão e a compra de estoques excedentes de café garantiam expressivo crescimento nacional, baseado, no entanto, em amplo endividamento. Sob o boom da borracha e com o bom desempenho do café entre os anos de 1900 e 1913, constatamos a permanência das companhias de seguros como instituições financeiras fundamentais e com papel cada vez mais expressivo na proteção das transações marítimas, cujos volumes aumentavam; ampliavam-se seguros de vida e acidentes para operários, que refletiam as mudanças no padrão da força de trabalho nacional e a complexificação do processo produtivo; as casas importadoras aumentavam a importação de máquinas e equipamentos, e seus agentes na maior parte das vezes eram também representantes de firmas seguradoras; e as companhias de seguros continuavam a comprar títulos da dívida pública e financiar o Estado brasileiro.

\footnotetext{
${ }^{476}$ BRASIL, Impressões do Brazil no século XX. Lloyd's Greater Britain Publishing Company, Arquivo Municipal de Cubatão, 1913, p. 290

${ }^{477}$ FRITSCH, Winston, obra citada, p. 43.

${ }^{478}$ CARDOSO DE MELLO, João Manuel, O Capitalismo Tardio. São Paulo: Editora Brasiliense, 1982, p. 90 .
} 
Por mais que profundamente dependente da renda agrícola e da exportação de bens primários, aos poucos o Brasil se distanciava da estrutura colonial de outrora, sobretudo no que diz respeito à remuneração da mão de obra e ao seu arranjo institucional, cujo impacto no funcionamento da economia e na condução das políticas econômicas era direto. Consideraremos que as companhias de seguros se inserem como exemplos de instituições que garantiam estabilidade à expansão do capital e ao funcionamento da economia real; a existência de firmas estrangeiras, mas também de casas nacionais, denota a percepção, à época, a respeito da importância dos seguros para o processo de acumulação capitalista. Faltava ao país, no entanto, oportunidades reais para incorporação do progresso técnico e para a formação de um mercado de capitais desenvolvido, capaz de servir ao financiamento produtivo. 


\section{Capítulo 3 - A dinâmica mercantil e financeira das companhias de} seguros no Brasil: exemplos empíricos.

Ao longo dos capítulos anteriores, buscamos apresentar a diversificação das atividades das seguradoras, que desde meados do século XIX ampliaram os tipos de seguros concedidos e mostraram-se fundamentais para o funcionamento do comércio e das relações, sobretudo mercantis, pelas quais o Brasil passou a se inserir na economia mundial. Conforme aproximava-se o final do século XIX, constatamos um aprofundamento da dimensão financeira dessas sociedades, cuja participação na esfera creditícia fazia-se clara. Essas características são encontradas nas fontes primárias analisadas, e nos capítulos anteriores apresentamos recorrentes casos de companhias de seguros nacionais e estrangeiras que investiam na dívida pública federal para além de sua obrigação (isto é, para além dos Rs 200:000\$000 os quais obrigatoriamente tinham que investir no Tesouro para poderem funcionar, de acordo com as regras da Legislação de 1895 e do Regulamento Murtinho de 1901.)

A emissão desses títulos tornava-se cada vez mais uma opção para o financiamento do Estado, cujas relações financeiras com o capital nacional e estrangeiro aos poucos ampliavam-se. Para o período em questão, temos que a dívida externa federal cresceu de 30,9 milhões de libras em 1890 para 44,2 milhões de libras em 1900 e 144,3 milhões de libras em 1913. ${ }^{479}$

Após realizarmos uma breve discussão teórica a respeito da composição do capital estrangeiro no Brasil da época, chegamos à conclusão de que, a despeito de expressivo, o número de companhias de seguros estrangeiras funcionando no Brasil entre 1889 e 1914 era menor que o total de firmas nacionais. $\mathrm{O}$ anteriormente apresentado Regulamento Murtinho, legislação promulgada pelo Ministro da Fazenda de Campos Sales em dezembro de 1901, afastou muitas das seguradoras estrangeiras aqui estabelecidas, que sofreram restrições e tiveram sua liberdade de atuação cerceada. Com o passar do tempo, e sobretudo após a revogação da legislação de Joaquim Murtinho em 1903, as companhias estrangeiras retornaram ao Brasil e voltaram a se estabelecer no mercado nacional, mas continuaram menos expressivas em termos quantitativos do que as firmas nacionais, como demonstramos nas Tabelas 4 e $5 .{ }^{480}$ Os dados a serem apresentados neste capítulo confirmam a hipótese de um significativo setor de seguros propriamente nacional no

\footnotetext{
${ }^{479}$ FRANCO, Gustavo, obra citada, p. 12.

${ }^{480}$ Página 70 deste trabalho.
} 
Brasil entre 1889 e 1914. O decreto de Joaquim Murtinho nos servirá como marco para a diferenciação de dois blocos temporais distintos neste capítulo, o primeiro indo de 1889 a 1901, e o segundo de 1901 a 1914. O primeiro bloco refere-se ao período anterior à promulgação do Regulamento Murtinho (Decreto $n^{\circ} 4.270$ ), época em que setor de seguros no Brasil era menos regulado e as sociedades estrangeiras não sofriam nenhum tipo de pressão ou constrangimento. Já o segundo bloco trata do momento posterior à regulamentação proposta pelo Ministro da Fazenda de Campos Salles, quando o setor passa a ser amplamente regulado e as firmas estrangeiras têm sua atuação severamente restringida no Brasil.

Após termos reconstituído o contexto político e econômico dos agitados primeiros anos da república brasileira, e apresentado os principais marcos na legislação normativa para o setor de seguros no Brasil, procuramos tratar dos principais casos encontrados nas fontes primárias; buscaremos, ao longo deste capítulo, aprofundar exemplos da dinâmica mercantil e financeira das companhias de seguros de então através de casos a respeito dos valores recebidos em forma de prêmios e juros, a inserção das firmas nos principais circuitos comerciais da época, a relação estabelecida com as companhias de navegação e estradas de ferro e o impacto da concessão de seguros em meio às reformas urbanas do início do século X. Finalizaremos apresentando o mapeamento e o cruzamento dos proprietários das companhias de seguros de então.

Até agora apresentamos análises de fontes primárias específicas, tais como os Relatórios dos Ministérios da Fazenda, jornais como Diário Oficial da União e Correio Paulistano, e o almanaque econômico Impressões do Brazil no Século XX. Neste capítulo trabalharemos a partir dos dados encontrados nos Anais do Poder Executivo e Legislativo entre os anos de 1889 e 1914; nessas fontes foi possível obter acesso aos estatutos das companhias de seguros, prestes a funcionar ou já em funcionamento, onde eram arrolados os principais objetivos e expectativas que estas sociedades possuíam no momento de sua fundação. Também pudemos encontrar descrições de operações de companhias já em funcionamento. Concluímos que o conteúdo presente nos estatutos dos Atos do Poder Executivo e Legislativo confirma os dados encontrados nas outras fontes primárias analisadas. 


\section{1- Análise empírica: 1889-1901}

Desde os estertores do Império, quando já era notável o movimento de entrada de capital estrangeiro no Brasil, notamos por parte do governo a preocupação em adequar leis e atos do poder executivo ao melhor rendimento das companhias, flexibilizando as medidas que pudessem afastar investidores do território nacional.

$\mathrm{O}$ anúncio público de mudanças e reformas nos estatutos das companhias, nacionais e estrangeiras, tornou-se obrigatório a partir da lei 3150, promulgada em 04 de novembro de $1882 .{ }^{481}$ A partir de então os aumentos e reduções de capitais, as alterações nas regras dos Conselhos e Assembleias e as mudanças no valor dos dividendos seriam informações conhecidas e acessíveis via imprensa.

O conteúdo da Coleção de Leis e dos Decretos Federais a partir de 1889 nos parece bastante claro nesse sentido, como nos momentos em que se permitiu a elevação de capital das sociedades forâneas e nacionais. A Companhia de Seguros Terrestres União dos Varegistas obteve, em janeiro de 1889, a permissão para elevar seu capital em até Rs 1.000:000\$000, dividindo-o em 5.000 ações de $200 \$$ cada uma. ${ }^{482}$ O limite ao aumento do capital de fundo das companhias era na maior parte das vezes determinado pelos próprios estatutos internos, como no caso da alemã Mannheimer Versicherunggeselschaft, que permitia aumento das emissões, porém apenas após a realização de ao menos $25 \%$ do capital nominal. ${ }^{483}$

Como dito anteriormente, devido à baixa taxa de poupança da economia brasileira à época, era esperado que as poucas rendas disponíveis rapidamente participassem da construção da dívida estatal. Ademais, o declínio do café fluminense a partir da década de 1870 tornou os títulos oficiais do governo bastante atraentes, levando os recursos do capital comercial nacional em direção à dívida pública. Entre os anos de 1898 e 1902, ao mesmo tempo em que grandes quantidades eram imobilizadas nos papéis estatais, o governo mantinha uma austera política monetária, cujo resultado foi uma conjuntura de baixa liquidez e escassez de papel moeda. ${ }^{484}$

A Imperial Fire Insurance Company, formada em 1803 na Inglaterra com o capital de um milhão e duzentas mil libras, ampliou seus negócios para o Brasil em setembro de 1863. A companhia incialmente concedia seguros para navios e embarcações em

\footnotetext{
${ }^{481}$ BRASIL. Decreto 3150, Actos do poder executivo, 1889, p. 593.

482 BRASIL. Decreto 10.171, Actos do poder executivo, 1889, p.133.

${ }^{483}$ BRASIL, Actos do poder executivo, 1889, p. 594.

484 TANNURI, Luiz Antonio, obra citada, p. 30.
} 
construção ancorados nos portos e docas, mas os seguros podiam se estender para navios em atividade, mercadorias por eles transportadas, edifícios e fazendas danificadas por fogo. Mesmo antes de sua expansão em direção à periferia do capitalismo, a sociedade já se propunha a realizar tais atividades em, nas suas palavras, "qualquer lugar do mundo". De acordo com seu estatuto, a firma iria: "fazer registrar a companhia ou reconhece-la em qualquer paiz, Estado ou logar no estrangeiro e fazer quaesquer empregos ou depositos e cumprir quaesquer condições necessarias ou convenientes de forma a realizar alli seus negocios." 485

De acordo com uma mudança de estatuto verificada em 1892, a Imperial Fire ampliou suas atividades e passou a realizar operações de seguro de acidentes de todos os ramos, e de fato se engajou em participações financeiras. As atividades previstas incluíam fusão com outras companhias, além da compra e absorção de operações com seguro de vida de outras sociedades e concessão de resseguros e contrasseguros. No que diz respeito às suas atividades no mercado de capitais, a atuação foi diversificada; empréstimos, depósitos e adiantamento de dinheiro, títulos e bens, além de emissão, saque e aceite de letras de câmbio, notas promissórias e debêntures.

Para além da convencional emissão, compra e venda de títulos, a companhia aprofundou sua dimensão financeira ao prestar serviços a outras sociedades auxiliandoas a vender, possuir ou remeter seus próprios títulos e ações. A Imperial Fire assumia a possibilidade de dirigir e fiscalizar os negócios de companhias em crise, em uma denominada "concessão recíproca" que abarcasse os interesses de ambas as partes. $\mathrm{O}$ auxílio prestado era definido como a realização de uma "sociedade ou ajuste para participar dos lucros, função de interesses, empresa ou cooperação com qualquer pessoa ou companhia (...) capazes de serem dirigidas de maneira direta ou indireta, beneficiar esta companhia e possuir (...) ações, ou capital, ou títulos, e subsidiar, garantir as apólices e contratos, e por outra forma auxiliar essa dita companhia e vender, possuir e remeter (...) e negociar com essa ações." 486

Se a participação das firmas estrangeiras em atividades subsidiárias à sua atuação original foi expressiva, deve-se levar em consideração o engajamento das elites locais nesses empreendimentos, situação característica das economias latino americanas do final do século XIX e início do XX. As empresas de serviços, crédito, a construção imobiliária e a especulação com a terra destacam-se como áreas onde os setores nacionais e

\footnotetext{
485 BRASIL, Actos do poder executivo, 1892, p. 829.

${ }^{486}$ BRASIL, Actos do poder executivo, 1892, p. 828.
} 
estrangeiros estiveram presentes. A Imperial Fire teve participação ativa no mercado imobiliário, e previa em seu estatuto "adquirir, arrendar, trocar, alugar, ou de qualquer forma adquirir quaesquer bens moveis ou imóveis em qualquer parte do mundo e quaesquer diretos ou privilegios que a companhia possa julgar necessario ou conveniente $(\ldots)^{\prime \prime} .487$

A companhia comprometia-se a reter as 400 mil libras que excedessem o capital realizado, de modo a formar um fundo de reserva para fazer face às possíveis reclamações contra as transações dos negócios. ${ }^{488}$ A busca por financiamento deveria ser realizada preferencialmente via debêntures. Os títulos estavam sujeitos a serem emitidos com um desconto, prêmios ou mesmo "privilégios especiais"489

Os registros que comprovam a compra dos títulos da dívida pública nacional por parte das companhias de seguros condizem com o crescimento desta última, que durante a primeira década republicana aumentou cerca de $53 \%$ em relação ao período anterior. ${ }^{490}$ Verificamos tal movimento nos balanços publicados na imprensa, e constatamos as expectativas que os estatutos das seguradoras possuíam, desde o momento de sua fundação, em adentrar a esfera financeira.

A Companhia de Seguro Mútuo contra Fogo Americana, formada em novembro de 1891 com sede no Rio de Janeiro, segurava propriedades móveis e imóveis, urbanas ou rurais, e de acordo com seu estatuto estavam previstas as concessões de seguros de "theatros, engenhos de café, canna de assucar e de serra, a vapor ou a mão, fabricas, officinas, salas e casas de espectaculos públicos e particulares, depósitos ou laboratórios (...) assim como mercadorias embarcadas, por mar ou por terra, em vias férreas, para qualquer ponto do paiz ou do estrangeiro, as quaes serão garantidas dos riscos de incendio, naufrágio, ou desastre casual." 491

Esta sociedade, assim como muitas outras apresentadas neste trabalho, mostrou predisposição para o envolvimento no mercado imobiliário e financeiro; fazia empréstimos sobre hipotecas de prédios urbanos, comprava e vendia apólices de outras sociedades, e alimentava a especulação imobiliária, em ascensão no Brasil durante e após o Encilhamento, através da construção e reconstrução de prédios em terrenos de terceiros,

\footnotetext{
${ }^{487}$ BRASIL, Actos do poder executivo, 1892, p. 828.

488 Ibidem, p.826

${ }^{489}$ BRASIL, Actos do poder executivo, 1892, p.843.

490 VILLELA, Anibal \& SUZIGAN, Wilson, Política do Governo e Crescimento da Economia Brasileira, 1889-1945. Rio de Janeiro, IPEA, 1973 apud CASTRO, Ana Celia, obra citada, p. 69.

${ }^{491}$ BRASIL, Actos do poder executivo, 1892, p. 720
} 
para venda imediata ou obtenção de aluguéis. Estavam previstas ainda as compras de ações, títulos e debêntures de bancos e companhias, bem como sua venda em momento apropriado. Comprava, vendia e descontava títulos da dívida do Governo Federal, e emprestava dinheiro sobre penhores de ouro e prata. $\mathrm{O}$ envolvimento com as obras de grande porte e com empresas de serviços públicos ocorria via liderança da Companhia de Seguro Contrafogo Americana em contratar "empreitadas" para construção de vias férreas, engenhos centrais, vilas, empreendimentos agrícolas, arrasamento de morros e abertura de ruas e calçamentos. Para finalizar suas amplas possibilidades de financiamento e investimento, estavam os empréstimos a "industriaes para a execução e desenvolvimento de qualquer invento proveitoso". ${ }^{492}$

Os prêmios obtidos eram depositados a juros em conta corrente em bancos considerados "de confiança por parte da diretoria". ${ }^{493}$ Os eventuais pagamentos de sinistros eram normalmente abatidos do fundo de reserva ordinário, cuja obrigação de abastecimento vinha antes dos pagamentos de dividendos. Porém, para além desse fundo, fazia-se necessário formar um fundo de reserva extraordinário, para o caso dos recursos dos prêmios e do fundo de reserva ordinário não serem suficientes para o pagamento de danos. O empréstimo seria pedido pela diretoria e poderia ser de até Rs 1.200:000\$000, com prazo de cinco anos e com juros de $8 \%$ ao ano.

\subsubsection{Prêmios e juros}

No que diz respeito à compra dos títulos da dívida pública, ao longo deste trabalho pudemos comprovar que esta atividade, apesar de extremamente recorrente nos balanços das companhias de seguros estudadas, não proporcionava sua maior fonte de renda. Raramente os valores dos juros das apólices adquiridas ultrapassavam os ganhos obtidos com os prêmios, que continuavam a ser a principal fonte de sustentação das firmas seguradoras. A seguir citaremos como exemplo alguns casos:

A Companhia Geral de Seguros, sociedade brasileira formada no Rio de Janeiro em 1878, recebeu Rs 241:792\$230 referentes a prêmios de seguros terrestres e Rs 183:849\$070 em seguros marítimos, totalizando Rs 425:641\$300. Os ganhos com juros

\footnotetext{
${ }^{492}$ BRASIL, Actos do poder executivo, 1892, p. 720

493 BRASIL, Actos do poder executivo, 1892. p. 794. 
totalizaram Rs 12:500\$000, referentes a 250 apólices da dívida pública no valor de Rs $1: 000 \$$ cada. $^{494}$

A Companhia de Seguros Marítimos e Terrestres Indemnizadora, em balanço referente ao ano de 1893, recebeu Rs 67:304\$230 em prêmios de seguros marítimos e Rs 45:121\$460 em terrestres, num total de Rs 112:425\$690. O recebimento de juros, por outro lado, fez-se em cima de 94 letras hipotecárias do Banco de Crédito Real de São Paulo, equivalentes a Rs 282\$000, 120 apólices da dívida pública com juros de 5\%, equivalentes a Rs 3:000\$000 e 30 apólices com juros de 4\% em ouro, equivalentes a Rs 1:383\$100. O ativo vindo dos juros da dívida pública para o ano de 1893 totalizava Rs 7:523\$900, muito menor, portanto, que os recursos recebidos via cobrança de prêmios. ${ }^{495}$

Essa mesma companhia, no referido ano de 1893, queixa-se das escassas operações com seguros marítimos de exportação ou importação decorrentes da instabilidade política em torno da Revolta da Armada, cujos efeitos geraram forte "apathia do comércio". Segundo Maria Barbara Levy, a Baía de Guanabara permaneceu cerca de seis meses fechada devido à Revolta, com evidentes efeitos negativos nos movimentos de importação. ${ }^{496}$ A situação instável teria levado a Sociedade a não distribuir dividendos no segundo semestre daquele ano; segundo Relatório apresentado à Assembleia Ordinária em abril de 1894, eram justamente os seguros marítimos os que melhor remuneravam as companhias de seguros, e os que produziam os melhores prêmios. Os seguros terrestres, sobretudo os dos prédios, dariam resultado pouco expressivo, incapazes de compensar as responsabilidades assumidas pela Companhia ao longo do referido ano. ${ }^{497}$

A Companhia de Seguros Marítimos e Terrestres Prosperidade ${ }^{498}$, sociedade brasileira formada no Rio de Janeiro em 1887, publicou no seu balanço de 1895 ganhos de Rs 242:730\$405 com prêmios; apesar de não haver a descrição dos juros ganhos pelos títulos da dívida pública, as apólices desta última totalizaram Rs 50:875\$380. ${ }^{499}$ Dez anos após a abertura de sua matriz no Rio de Janeiro, a companhia possuía filiais em Curitiba,

\footnotetext{
${ }^{494}$ BRASIL, Diário Oficial da União, 26 de fevereiro de 1897, p. 959, 960. Algumas exceções, no entanto, podem ser citadas. Em seu balanço referente à 1909 a Companhia Paulista de Seguros teve $73 \%$ de suas receitas vindas de títulos financeiros, superando os valores vindos dos prêmios. Seu caso será apresentado mais à frente. BRASIL, Correio Paulistano, Arquivo Público do Estado de São Paulo, 25 de julho de 1909, p. 06.

495 BRASIL. Diário Oficial da União, 04 de abril de 1894, 1023, 1024

${ }^{496}$ LEVY, Maria Barbara, História da Bolsa de Valores do Rio de Janeiro. Rio de Janeiro: IBMEC, 1977, p. 281.

${ }^{497}$ BRASIL. Diário Oficial da União, 04 de abril de 1894p. 1022.

498 Não confundir com a Companhia Prosperidade, formada no Rio de Janeiro em 1845, dedicada aos seguros de vida de escravos e já citada nestra trabalho

${ }^{499}$ BRASIL, Diário Oficial da União, 23 de abril de 1896, p.1912.
} 
Santos e São Paulo. A agência de Curitiba era comandada pelo chefe de um grande estabelecimento de erva mate local, cujo amplo comércio com as Repúblicas do Rio da Prata permitiu à Companhia de Seguros Marítimos e Terrestres Prosperidade substituir as sociedades estrangeiras na concessão de seguros ao mate exportado pelo Paraná. ${ }^{500}$

Segundo a diretoria da Prosperidade, em comentário a respeito do Encilhamento publicado no Diário Oficial em abril de 1893, os balanços de 1892 permaneciam razoáveis e a Prosperidade continuava a manter seus créditos, "apezar da crise financeira e depressão de negócios que atravessa a praça." O total dos prêmios faturados naquele ano totalizavam o montante de Rs 125:338\$060, bastante razoável para um contexto de crise, mas menor, por exemplo, que os Rs 242:730\$405 arrecadados em 1895, quando o Brasil já caminhava rumo à estabilização. ${ }^{501}$ Após o Encilhamento e com a melhora do cenário econômico, a companhia viu seu endividamento via letras diminuir pela metade; os Rs 88:640\$000 devidos em 31 de dezembro de 1891, passou para Rs 42:408\$400 em 31 de dezembro de 1892. Seu fundo de reserva também passou por melhorias, aumentando cerca de Rs $32 \$ 240 \$ 085$ entre 1891 e 1892.502

Apesar dos prêmios representarem a maior parte do lucro das companhias de seguros, analisamos sucessivos casos onde os juros sobre os títulos, sobretudo os da dívida pública, compunham parte importante dos rendimentos dessas firmas. O depósito obrigatório de Rs 200:000\$000 no Tesouro Nacional, desde 1895 exigido pelo governo como pré-condição para que as seguradoras ganhassem suas cartas de funcionamento, era apenas uma parte da relação entre essas firmas e as apólices federais. $\mathrm{O}$ envolvimento das companhias com a dívida pública nacional foi mais amplo, e compôs parte importante da crescente dimensão financeira de suas atividades.

\section{$\underline{\text { 3.1.3 - A companhias de seguros no Sul do Brasil e no circuito comercial do Rio da Prata }}$}

A inserção das firmas importadoras e exportadoras do Sul do Brasil no circuito comercial do Rio Prata era notável, e muitas funcionavam como agentes e representantes de companhias de seguros, nacionais e estrangeiras. Entre 1883 e 1913 funcionou de forma muito próspera no Rio Grande do Sul a casa Segismundo Kramer \& Filhos, importadora de secos e molhados de diversos países europeus, cereais da Argentina, açúcar de Pernambuco e café do Rio de Janeiro; exportava sobretudo couros e lãs para

\footnotetext{
${ }^{500}$ BRASIL, Diário Oficial da União, 23 de abril de 1896, p.1912.

${ }^{501}$ BRASIL, Diário Oficial da União, 28 de abril de 1893, p. 01.

502 Ibidem, p. 01.
} 
Montevideo. ${ }^{503}$ A firma era agente do London \& River Plate Bank; do London \& Brazilian Bank; da casa Superville \& Cia., de Buenos Aires; das companhias de seguros La Previsora e La Positiva, também de Buenos Aires; foram também agentes da famosa New York Life Insurance Company. ${ }^{504}$

Exemplos de estabelecimentos exportadores de mate que também funcionavam como agentes de companhias de seguros, estabelecidos no Sul do Brasil, foram encontrados nas fontes primárias; estes casos podem ser citados como exemplos da estreita relação entre as companhias de seguros e as companhias de comércio. Dentre as principais agentes da Guardian Insurance Co. de Londres estava a Guimarães \& Cia., fundada em Paranaguá em 1833 e exportadora de erva mate, sal, açúcar e arroz. A firma também mantinha grandes depósitos onde armazenava farinha de trigo importada, e possuía um engenho para beneficiar mate no próprio porto de Paranaguá. A exportação de mate beneficiado nas suas fábricas atingiu cerca de $6.000 .000 \mathrm{~kg}$ no ano de 1913 , a maioria enviado à Argentina e Uruguai; parte considerável, no entanto, ia para as firmas sucursais em Curitiba, Antonina e Ponta Grossa. ${ }^{505}$ Seus proprietários eram ainda agentes de companhias de vapores que percorriam o circuito Rio da Prata, Santos, Rio de Janeiro e Pernambuco, dentre as quais a Sociedad Anónima de Navegación Sud-Atlántica, a A. Lafranco \& Cia. e a Lamport \& Holt Line. ${ }^{506}$

Por fim, citamos o caso da A. Baptista \& Cia., casa de Joinville, Santa Catarina, firma importadora e exportadora considerada das mais prósperas do Sul do país. Fundada em 1896, era também uma propriedade fabril, com três engenhos de erva mate, fábrica de pregos, arame farpado, tecidos de arame, moinhos de arroz, serrarias a vapor, entre outros negócios. A produção de erva mate dos engenhos era de cerca de 3.700 .000 kg por ano; as outras fábricas produziam anualmente $900.000 \mathrm{~kg}$ de pregos, $5.000 \mathrm{~kg}$ de grampos, 7.000 rolos de arame farpado e 12.000 metros de tecidos de arame. A fábrica de manufaturados possuía 28 máquinas e empregava 52 pessoas. Interessante notar que os engenhos e moinhos, movidos a vapor, no ano de 1913 começavam aos poucos a trabalhar a partir de eletricidade. ${ }^{507}$

\footnotetext{
${ }^{503}$ BRASIL, Impressões do Brazil no século XX. Lloyd's Greater Britain Publishing Company, Arquivo Municipal de Cubatão, p. 867.

504 Ibidem, p. 867

505 BRASIL, Impressões do Brazil no século XX, (...), p. 970.

506 Ibidem, p. 970

${ }^{507}$ BRASIL, Impressões do Brazil no século XX. Lloyd's Greater Britain Publishing Company, Arquivo Municipal de Cubatão, 1913, p. 1019.
} 
A filial ficava na cidade catarinense de São Francisco do Sul, onde ao lado do principal porto funcionava o Trapiche do Comércio, ponto onde atracavam os vapores de cujas companhias a A. Baptista \& Cia. era agente. A firma representava as companhias de navegação Lloyd Brasileiro e Gulf Line, além da Companhia de Seguros Marítimos e Terrestres Pelotense. ${ }^{508}$

Todos os detalhes a respeito do comércio dessas firmas foram descritos com o intuito de apresentar quão amplas eram as possibilidades de inserção do capital no Brasil do início do século XX. Temos que o comércio de seguros era parte de uma vasta rede que incluía comerciantes, proprietários fabris, negociantes, casas importadoras e exportadoras e companhias de navegação. Os nomes por trás desses negócios envolviamse com as companhias de seguros sobretudo a partir da função de agentes, dados os contatos e as possibilidades de inserção no mundo dos negócios que possuíam de antemão.

\subsubsection{As companhias de seguros e as de navegação}

O interesse de companhias de navegação pela concessão de seguros também se fez presente. Citamos o caso da britânica Companhia Lupton, com agências em São Paulo desde o ano de 1891, que concedia seguros às mercadorias transportadas por seus próprios vapores. ${ }^{509}$ Outro exemplo é a Companhia Comércio e Cabotagem, formada no Rio de Janeiro em abril de 1891, cujo objetivo principal era estabelecer o serviço de cabotagem na costa brasileira, com navios à vela ou vapor, além de "fomentar e dar o mais amplo desenvolvimento ao serviço marítimo intermediário, na bahia do Rio de Janeiro e em outros portos (...) e comerciar, por conta própria, em generos alimenticios" ${ }^{\prime 510}$ Além dos objetivos acima descritos, outras atividades como construção e aquisição de estaleiros para construção de navios, fretes de embarcações e amplo envolvimento em operações de seguros e resseguros das mercadorias embarcadas nos navios da companhia, bem como de outras sociedades, também eram realizadas.

O envolvimento por parte das companhias de navegação no negócio de seguros significou que elas próprias emitiam e vendiam suas apólices de seguros contra acidentes marítimos. A maior parte dos compradores dos seguros vendidos pelas companhias de

\footnotetext{
${ }^{508}$ BRASIL, Impressões do Brazil no século XX. Lloyd's Greater Britain Publishing Company, Arquivo Municipal de Cubatão, 1913, p. 1019.

${ }^{509}$ BRASIL, Correio Paulistano, 01 de março de 1891, p. 4.

${ }^{510}$ BRASIL, Actos do poder executivo, 1891, p. 298.
} 
navegação eram seus próprios clientes, comerciantes que já usufruíam dos serviços de navegação da empresa. Podemos entender a construção de seções de seguros no âmbito das companhias de navegação como uma tentativa destas últimas baratearem seus custos operacionais, internalizando as funções de seguradoras e reduzindo seus custos de transação; na maior parte dos casos, no entanto, as embarcações utilizavam os serviços de outras companhias. ${ }^{511}$

O processo de construção do setor de seguros, bastante almejado, era desde o início da Companhia Comércio e Cabotagem algo previsto de ser realizado. Um fundo especial de seguros seria formado, e quando atingisse a soma de Rs 3:000\$000, as cotas destinadas semestralmente aos seguros de navios eram distribuídas aos acionistas como dividendo especial. ${ }^{512}$

A Comércio e Cabotagem pode ser citada como exemplo de sociedade que se auto financiava, já no início da primeira década republicana, via emissão de debêntures. ${ }^{513}$ Estas últimas eram títulos relativamente recentes na economia brasileira, e cabe aqui tratarmos a respeito das possibilidades de financiamento do capital privado de então. Desde 1882, ano em que foi revogada a Lei dos Entraves de 1860, tornou-se possível às sociedades anônimas brasileiras ou instaladas no Brasil organizarem-se sem a autorização legislativa do governo. É possível interpretar a revogação da Lei dos Entraves como o entendimento, por parte do governo na década de 1880, da impossibilidade de empresas em formação disporem de capacidade própria de financiamento. É nesse contexto em que foram autorizadas novas opões de captação de recursos, como a emissão de debêntures. ${ }^{514}$

Tanto as seguradoras quanto as companhias de navegação se beneficiavam conforme o comércio marítimo do final do século XIX e início do XX tornava-se mais ativo e os serviços mais complexos e melhor remunerados. Era comum em portos como no Rio de Janeiro, Santos ou Vitória que as firmas contratadoras de estivadores trabalhassem para as companhias de seguros e também de navegação, e que cumprissem

\footnotetext{
${ }^{511}$ A respeito da redução dos custos de transação via internalização de determinadas funções pela própria firma, no lugar de buscar a contratação dos serviços de terceiros, ver COASE, Ronald, The firm, the market and the law. Chicago: The Chicago University Press, 1988, p. 40, p. 55; WILLIAMSON, Oliver, "Transaction cost economics: The governance of contractual relations". Jornal of Law and Economics, 1979. In WILLIAMSON, Oliver, The Transaction Cost Economics Project: the theory and practice of the governance of contractual relations. Northampton: Edward Elgar Publishing, 2013, p. 25.

512 BRASIL, Actos do poder executivo, 1891, p. 304.

${ }^{513}$ Ibidem p. 302.

${ }^{514}$ LEVY, Maria Bárbara, A indústria do Rio de Janeiro através das suas sociedades anônimas. Rio de Janeiro: Editora UFRJ, 1994, p. 115.
} 
com o papel de agentes dessas sociedades. Citaremos como exemplo o caso de Antenor Guimarães, proprietário de cinco lanchas e 25 chatas e envolvido no comércio marítimo, sobretudo entre o Rio de Janeiro e Espírito Santo; seu capital em 1913 era de Rs 400:000\$000 e o movimento anual das mercadorias transportadas por estivadores era de Rs. 2.200:000\$000. ${ }^{515}$ Antenor Guimarães era representante de várias sociedades, dentre as quais a Companhia de Seguros Varejista, a Companhia Comércio e Navegação, a Empresa de Navegação Esperança, o Norddeutscher Lloyd, a Brazil Transport Line, a Hamburg Amerika Linie; representava também a Estrada de Ferro Vitória-Diamantina, da Société Minière et Industrielle Franco-Bresilienne de Paris (exportadores de areias monazíticas), a Hamburg Sudamerikanische, e a Companhia São João da Barra. ${ }^{516}$

Se nos detivermos sobre as condições sob as quais as companhias de seguros buscavam seu autofinanciamento, temos que os títulos emitidos pelo capital privado à época sofriam forte concorrência com a ampla disponibilidade de apólices da dívida pública estatal, cuja emissão, como já sabemos, cresceu de forma significativa a partir da década de 1870; além de muitos disponíveis, esses títulos públicos eram considerados seguros e dotados de relativa liquidez.

Sabemos que desde a década de 1830, isto é, no momento próprio de sua fundação, o Estado brasileiro optava por se financiar via colocação desses títulos públicos no mercado, embora por vezes também recorresse à emissão de moeda. ${ }^{517} \mathrm{O}$ expressivo crescimento da compra de títulos públicos tornava-se um padrão de investimento, sobretudo em época de crise do capital cafeeiro do Vale do Paraíba fluminense; a produção agrícola não era uma opção rentável como havia sido outrora, e os proprietários fundiários do Rio de Janeiro se sentiam seguros mantendo suas reservas sob a dívida nacional. Como consequência tem-se que a imobilização de recursos em títulos públicos, no contexto de uma economia muito pouco monetizada como a brasileira de então, redundou em escassez de numerário e crise de liquidez, característica que acompanha os anos entre $1870-1890.518$

É sob a referida crise de liquidez que serão implantadas as reformas de Rui Barbosa, que dentre outras medidas propôs que se lastreasse a moeda emitida em títulos

\footnotetext{
515 BRASIL, Impressões do Brazil no século XX. Lloyd's Greater Britain Publishing Company, Arquivo Municipal de Cubatão, 1913, p. 1034

${ }^{516}$ Ibidem, p. 1034

517 SUMMERHILL, William, Inglorious Revolution: Political Institutions, Sovereign Debt, and Financial Underdevelopment in Imperial Brazil. Yale University Press, 2015, p. 03.

518 TANNURI, Luiz Antonio, obra citada, p. 30.
} 
da dívida pública, e não mais em ouro; as reservas metálicas deveriam ser utilizadas para monetizar o grande território nacional, remunerar a mão de obra livre e constituir o capital fixo e circulante do país. A manutenção do padrão ouro, segundo o primeiro Ministro da Fazenda republicano, serviria apenas para manter entesourados os metais necessários à modernização monetária. Os títulos passam então a ter sua oferta no mercado restrita, situação que contribui para que a elite brasileira, acostumada apenas com os títulos estatais, se veja obrigada a procurar outros ativos como debêntures e ações..$^{519}$

\subsubsection{As propriedades móveis e imóveis e as companhias de estrada de ferro}

A concessão de seguros às propriedades urbanas, fossem particulares ou do governo, era frequente desde o final do Império. A Companhia de Seguros Mútuos Contrafogo Esperança, cujo funcionamento remete a 1889, tinha como fim a venda de seguros mútuos para proprietários que quisessem garantir de maneira recíproca as perdas advindas de incêndios, além de segurar os aluguéis dos prédios da Corte (ainda no Império), bem como aqueles de propriedade do novo governo republicano. Além das apólices da dívida pública, as reservas dessa seguradora eram investidas em letras hipotecárias ou em sociedades de crédito real. ${ }^{520}$ Os prêmios obtidos através dos diferentes seguros eram recolhidos por meios de bancos, definidos pelo diretor, de acordo com o conselho fiscal, e lá depositados a juros de conta corrente. ${ }^{521}$

O fundo de reserva não deveria ultrapassar os Rs 200:000\$000, tidos como valor padrão. Se passasse desse valor, o montante poderia ser utilizado para pagamento de dividendos. Notamos a importância do Fundo de Reserva como instituição financeira cuja manutenção vinha à frente mesmo da distribuição dos dividendos. A manutenção dos saldos ociosos, bem como a utilização produtiva destes últimos por meio de empréstimos, era algo bastante almejado pelo governo, sobretudo após as tentativas de recuperação do valor da moeda no pós Encilhamento.

A London Lancashire Fire Insurance Company, companhia inglesa de 1861 e no Brasil desde 1866, dividia seu capital entre Fundo Geral e Fundo de Reserva, o primeiro formado pelo capital realizado e prêmios, e o segundo por saldos e haveres extras que pudessem formar o crédito da companhia. As obrigações e demais pagamentos deveriam ser feitos em primeiro lugar pelos prêmios e juros de empréstimos concedidos. No caso

\footnotetext{
${ }^{519}$ LEVY, M ${ }^{\text {a }}$ Bárbara, obra citada, p. 128.

${ }^{520}$ BRASIL, Actos do poder executivo, 1889, p. 555

${ }^{521}$ Ibidem, p. 556
} 
de serem insuficientes, buscar-se-iam os recursos do fundo de reserva, e em último caso se entraria no capital da companhia. ${ }^{522}$ Novamente, a importância do fundo de reserva pode ser verificada pelo fato de que, enquanto este último não atingisse o montante de 100.000 libras, não se fazia distribuição alguma de dividendos no ano correspondente.

Em 1914 a seguradora continuava em funcionamento no Brasil, com suas principais agências no Rio de Janeiro e em São Paulo. A essa altura a companhia dividia seus fundos de reserva nas categorias incêndio, marítimos, acidentes e pensões, sendo o mais alto deles o destinado aos incêndios, que desde o final de 1913 e no primeiro semestre de 1914 ocorriam com frequência atípica nas capitais paulista e fluminense, numa onda suspeitosa de recorrentes fraudes. ${ }^{523}$

Em balancete publicado no Correio Paulistano referente a dezembro de 1913, notamos o quanto o ativo da London and Lancashire Company naquele período era composto sobretudo por seus títulos e operações financeiras. Aluguéis de prédios no Brasil, no Reino Unido e no que a companhia denominava como "colônias"; hipotecas e debêntures; apólices do governo britânico; ações garantidas e preferenciais de estradas de ferro britânicas e norte-americanas; apólices norte-americanas, municipais, estaduais e federais; apólices brasileiras; juros acumulados de diversos devedores e saldo de conta corrente com agentes e sucursais fora do Reino Unido compunham praticamente a totalidade de seu ativo, sendo o saldo dos prêmios da venda de seguros correspondentes a menos de $1 \%$ das operações totais que compunham o ativo daquele momento. ${ }^{524}$

Se no estatuto da London and Lancashire estava previsto que os prêmios acumulados pudessem ser investidos em diversas frentes, porém todas limitadas à GrãBretanha ou EUA, sabemos que com o passar dos anos essa realidade alterou-se, a julgar pela compra de diversos títulos dessa sociedade no Brasil. ${ }^{525}$ As operações da sociedade em São Paulo e no Rio de Janeiro eram administradas pelos agentes Zerrener \& Bülow. ${ }^{526}$

Em janeiro de 1894, foi aberta a Companhia de Seguros Mútuos contrafogo e sobre Vida Cruzeiro, com sede no Rio de Janeiro e filiais em outros Estados, concedendo seguros a qualquer propriedade móvel ou imóvel. Mesmo sofrendo com as consequências da crise do Encilhamento, àquela época o país convivia com a abertura de novas firmas e sociedades de capital aberto no ramo dos seguros. A companhia também previa a

\footnotetext{
522 BRASIL, Actos do poder executivo, 1889, p. 55

${ }^{523}$ BRASIL, Correio Paulistano, Arquivo do Estado de São Paulo, 03 de junho de 1914, p. 06.

${ }^{524}$ BRASIL, Correio Paulistano, Arquivo do Estado de São Paulo, 03 de junho de 1914, p. 06.

525 Ibibem, p. 06

${ }^{526}$ BRASIL, Correio Paulistano, Arquivo do Estado de São Paulo, 20 de fevereiro de 1905, p. 4. 
concessão de heranças por meio de contribuições semestrais, anuais ou de uma só vez; para tanto era necessário uma caixa de formação de pecúlio e dotes. ${ }^{527}$ As contribuições, de $25 \$$ durante 20 anos, ou de $50 \$$ por 10 anos, eram empregadas a juros compostos e formavam um patrimônio para aqueles que atingissem a idade de 20 anos. ${ }^{528}$ A companhia considerava-se apta a funcionar após ser subscrito o capital de Rs 500:000\$000, podendo este último ser elevado conforme o funcionamento da sociedade.

Como em outras companhias, os prêmios provenientes de seguros feitos durante o ano social eram recolhidos em conta corrente em um estabelecimento bancário de confiança da diretoria. ${ }^{529}$ Os recursos do fundo de reserva eram empregados sobretudo na compra de títulos da dívida pública nacional. ${ }^{530}$ Como dito acima, o fundo de reserva era considerado mecanismo central na regulação do patrimônio das companhias; a partir de sua constituição pagavam-se os sinistros e compravam-se os títulos, fossem da dívida pública do governo ou debêntures de outras sociedades. Considerando que o expressivo funcionamento da parte financeira das companhias de seguro dependia da constituição dos fundos de reserva, faz sentido constatarmos que os dividendos não reclamados no prazo de cinco anos, ao invés de serem distribuídos entre os acionistas, eram imediatamente remetidos ao fundo em questão. ${ }^{531}$

Em maio de 1894, o Ministério da Indústria, Viação e Obras Públicas aprovou o prolongamento da Estrada de Ferro da Bahia ao São Francisco. ${ }^{532}$ A estrada de ferro, inaugurada em 1863, ligava Salvador ao município de Alagoinhas, no litoral da Bahia, e era a primeira ferrovia daquele estado. Sua concessão fora dada a investidores ingleses e passou a se chamar Bahia and São Francisco Railway Company. Depois de ter sido propriedade da empresa franco-belga Compagnie des Chemins de Fer Fédéraux de l'Est Brésilien no começo do século XX, a ferrovia foi encampada pelo governo de Getúlio Vargas, em 1935.

Nas instruções para o transporte de passageiros e mercadorias na estrada de ferro são estabelecidas regras no que diz respeito ao frete, às mercadorias nocivas, armazenagens e indenizações. Os seguros poderiam ser realizados na própria estrada, sem que houvesse a necessidade de contratação de companhias; bastava declarar, no ato do

\footnotetext{
${ }^{527}$ BRASIL, Actos do poder executivo, 1894, p. 127.

${ }^{528}$ Ibidem, p. 136.

${ }^{529}$ BRASIL, Actos do poder executivo, 1894, p. 128.

${ }^{530}$ BRASIL, Actos do poder executivo, 1894, p. 128.

${ }^{531}$ Ibidem, p. 130.

532 BRASIL, Actos do poder executivo, 1894, p. 454.
} 
despacho, o valor segundo o qual o viajante gostaria de ser indenizado em caso de perda ou deterioração dos seus bens, não podendo haver seguro superior a Rs 1:000\$000 (valor de apólice elevado se comparado ao padrão da época).

No caso de perda total dos bens, o segurado recebia o valor total declarado; se apenas uma parte fosse danificada, recebia-se apenas o equivalente à perda parcial sofrida, e em nenhum caso a indenização poderia exceder o dano realmente sofrido pelo segurado. Essa exigência distingue a concessão de seguros da administração da estrada daquela realizada por companhias. No caso destas últimas, a enorme preocupação com os recursos do fundo de reserva permitia ampla cobertura dos sinistros.

\subsubsection{Diversificação das nacionalidades}

Conforme avançava a segunda metade do século XIX era possível verificar a diversificação do capital aportado no Brasil no que diz respeito a sua nacionalidade; a existência de empresas alemãs se fez cada vez mais presente a partir da década de 1870 . A Companhia de Seguros contrafogo Magburgo, formada em 1870 em Hamburgo, na Alemanha, iniciou suas atividades no Brasil em fevereiro de 1895, recebendo do governo autorização para estabelecer agências no Rio de Janeiro, na Bahia, Espírito Santo, São Paulo, Paraná e Rio Grande do Sul. ${ }^{533}$

O capital social da companhia era de Rs 5.000\$000 em moeda corrente na Prússia, divididos em 5.000 ações. As entradas de ações, assim como os fundos de reserva, seriam empregadas em "títulos públicos da Alemanha ou de um dos Estados alemães, letras de penhor, hypoteca, ou venda no interior do paiz, obrigações de cidades alemãs, acções privilegiadas ou de prelação ou ações garantidas de estradas de ferro nacionais, ou serão emprestadas contra garantia hypothecária perfeita ou outro penhor suficiente, com exclusão de mercadorias." ${ }^{234}$

O valor dos prêmios deveria ser empregado no desconto de boas letras; essa atividade só seria realizada se não representasse distorção do fim original da companhia e não lhe acarretasse prejuízo. O objetivo dessa proposta parece ser o de ampliar o número de pontos de desconto de letras, fazendo uso financeiro das poupanças disponíveis e consolidadas. Não sabemos se tal procedimento permaneceu funcionando quando a companhia ampliou sua participação para o Brasil; a possibilidade de se descontar letras

\footnotetext{
${ }_{533}$ BRASIL, Actos do poder executivo, 1895, p. 63.

534 BRASIL, Actos do poder executivo, 1895, p. 64. 
nas próprias companhias de seguro, no caso das matrizes alemãs, estabelecia uma relação direta entre a companhia e o devedor.

O fundo de reserva da companhia deveria ser de 1.500.000 marcos. No caso do fundo sofrer perdas e tiver seu valor reduzido, seria administrado separadamente e o rendimento dos juros deveria ser empregado para que o montante voltasse a atingir a referida soma. No caso de os juros não serem o suficiente para a reconstituição do fundo de reserva, seriam retirados $20 \%$ dos lucros. ${ }^{535}$

Apesar das semelhanças com companhias brasileiras no que diz respeito ao funcionamento do capital de reserva, a alemã Magdeburgo possuía maior preocupação com a constituição de um patrimônio de garantia. Dos lucros líquidos restantes após a distribuição de salários e dividendos, metade formava um segundo fundo, denominado fundo de economia, e a outra metade era distribuída aos acionistas como segundo dividendo. $\mathrm{O}$ fundo de economia servia, basicamente, para cobrir as perdas que o fundo de reserva não conseguisse administrar. Nos anos financeiros em que não houvesse necessidade de utilizar os recursos dos fundos para cobrir grandes sinistros, os dividendos distribuídos poderiam ser maiores. ${ }^{536}$

Ao longo do trabalho com as fontes primárias, poucos exemplos da chegada de capital italiano na área de seguros ao Brasil foram encontrados. Nos Atos do Poder Executivo achamos o caso da Societá Italiana di Esportazione Enrico Dell’Aqua, original de Milão, que abriu uma filial em São Paulo em outubro de 1899. A Sociedade fazia pagamentos, sacava, endossava e exigia cambiais, sendo proibida, no entanto, de aceitar ou emitir tais valores. Era responsável também por intervir em ajustes de contas, liquidações e partilhas, além de providenciar expedições e participar de contratos de transportes, de fretes e de seguros. No caso de falência de outras sociedades, a Enrico Dell’Aqua representava-as, declarava seus créditos e votava pelos pedidos de moratória. A participação financeira da sociedade exportadora ocorria nas compras e vendas de ouro para operações comerciais e para segurar contratos. ${ }^{537}$

Assim como a maior parte das companhias de exportação da época, a sociedade envolveu-se com atividade comercial e marítima, recebendo e administrando volumes e mercadorias dos depósitos das alfândegas. Segundo o estatuto da sociedade, era previsto "tirar de quaesquer escriptorios publicos ou particulares, cartas ordinárias registradas ou

\footnotetext{
${ }^{535}$ BRASIL, Actos do poder executivo, 1895, p. 72.

${ }^{536}$ BRASIL, Actos do poder executivo, 1895, p. 75.

${ }^{537}$ BRASIL, Actos do Poder Executivo, 1899, p. 1487
} 
outras, valores, dinheiros, mercadorias e quaesquer outros objetos, receber o importe dos valores postais ou outros, bem assim como quaesquer outros títulos e effeitos, tirar de quaesquer repartições, tesouros, bancos ou de particulares que em nome da sociedade achar-se-hão disponíveis, servindo-se para isso de cheques, saques, mandatos ou outros efeitos." ${ }^{\prime 538}$

A despeito da diversificação de origem das firmas aportadas no Brasil, sobretudo na última década do século XIX, o capital britânico continuou expressivo em termos absolutos. Em dezembro de 1896 passou a funcionar no Brasil a companhia inglesa Manchester Fire Assurance Company, com autorização para abrir agências no Rio de Janeiro, Salvador, Recife, São Paulo, Santos e Porto Alegre. De acordo com o Decreto $\mathrm{n}^{\circ}$ 2395 de 04 de dezembro de 1896, assinado pelo futuro Ministro da Fazenda e à época senador Joaquim Murtinho, a companhia era obrigada a ter um representante no Brasil "com plenos e illimitados poderes para tratar e definitivamente resolver as questões que se suscitarem, quer com o Governo da União ou dos Estados, quer com particulares." ${ }^{539}$

O trecho reivindica que sociedades estrangeiras cuidassem de uma disponibilidade administrativa local, de modo que seus problemas pudessem ser devidamente resolvidos no Brasil sem a necessidade de remessa de informações ao centro, cuja espera da resposta comprometia as condições de funcionamento da economia doméstica. Joaquim Murtinho também deixava claro que a Manchester Fire Assurance Company deveria se submeter às leis e jurisdições brasileiras, comprometendo-se a não reclamar exceções previstas em seus estatutos e muito menos, em casos de desrespeito à regulamentação nacional, buscar apoio em intervenções diplomáticas. O desrespeito das normas previstas acarretaria multas de Rs 200 a Rs 2:000\$000. ${ }^{540}$

A Manchester Fire Assurance Company havia sido originalmente criada em março de 1817, na cidade homônima, sob o nome de The Manchester Fire and Life Assurance Company, tratando de seguros de vida e contrafogo. A sociedade foi registrada na Inglaterra apenas em março de 1847, quando contava com capital de 2.000.000 libras esterlinas dividido em ações de 100 libras cada uma. Sua dissolução ocorreu em setembro de 1892, mas parte do corpo constitutivo de sua assembleia geral, diretoria e acionistas logo em seguida criou a nova sociedade sob o novo nome, comprometida apenas com seguros contrafogo.

\footnotetext{
${ }^{538}$ BRASIL, Actos do Poder Executivo, 1899, p. 1487

539 BRASIL, Actos do Poder Executivo, 1899, p.694 (destaques meus)

540 Ibidem, p. 694
} 
O capital dessa vez seria menor: 1.000 .000 libras esterlinas divididas em 10.000 ações de 100 libras cada, não podendo nunca ser elevado. A companhia teve desde seu início pretensões de expansão para além de Manchester, prevendo a exportação de seu capital para operações em quaisquer lugares que "a diretoria julgasse apropriados." ${ }^{541}$ Suas atribuições, originalmente restritas à concessão de seguros contra fogo, ampliaramse para proteção contra quaisquer perdas e danos a propriedades de qualquer natureza, imóveis, e mercadorias "em trânsito em terra ou por água". Eram também atividades da companhia:

fazer e effectuar todos e quaesquer negocios ou fazer todas as materias e cousas como acima dito, quer no Reino Unido quer em quaesquer dos seus domínios coloniais ou dependencias ou em qualquer paiz ou Estado estrangeiro, fazer e celebrar e levar a effeito quaesquer contractos ou contracto, para tomar a si (...) gerir, arrendar, hypotecar ou fazer outra qualquer transacção relativamente aos bens de raiz, moveis ou semoventes, adquiridos ou possuídos pela companhia de conformidade com a escriptura de accordo, e fazer operações de crédito para os fins da companhia (...). ${ }^{542}$

A extensão das atividades para a periferia do capitalismo submetia a atuação da Manchester Fire Assurance Company a circunstâncias absolutamente distintas daquelas de Manchester, cidade do Noroeste da Inglaterra cujo papel para o despontar da Revolução Industrial foi crucial. A concessão de crédito e seguros em um ambiente industrializado e altamente intensivo em capital era profundamente distinta daquela realizada em uma sociedade recém-saída do modelo escravista, cuja produção baseavase na exportação de bens primários, os mercados consumidor e de capitais eram quase inexistentes, as instituições fracas e as condições macroeconômicas pouco favoráveis ao investimento. Sabemos que em 1896, ano em que a Manchester Fire Assurance Company é estabelecida no Brasil, o país ainda sofria com as consequências da crise do Encilhamento, resolvida apenas em 1898 com as medidas saneadoras de Joaquim Murtinho. As atividades econômicas encontravam-se constantemente ameaçadas pela inflação e pela vulnerabilidade cambial, o que escancarava os limites encontrados pelo capital estrangeiro quando almejava sua expansão em direção à periferia.

A despeito dessas más condições, as firmas estrangeiras continuavam vindo para o Brasil a fim de expandirem suas atividades; se a partir de 1898 encontram melhores

${ }^{541}$ BRASIL, Actos do Poder Executivo, 1899, p. 698.

${ }^{542}$ BRASIL, Actos do Poder Executivo, 1899, p. 703 (destaques meus). 
possibilidades de investimento devido as reformas macroeconômicas levadas à cabo por Joaquim Murtinho, entre 1901 e 1904 o ambiente deixaria de ser tão favorável a essas companhias de seguros estrangeiras, que passam a ter que lidar com uma legislação restritiva a sua atividade idealizada pelo mesmo Ministro.

Até que ponto estes últimos desarranjos foram eliminados ou controlados conforme avançava a chegada do capital estrangeiro ao longo do século XIX e XX, temse muito o que discutir; pode-se afirmar desde já, no entanto, que sob o funcionamento das firmas estrangeiras o país não vivenciou rupturas estruturais com seu modelo primário e exportador. O que sabemos, e pudemos comprovar com as fontes primárias ao longo deste trabalho, é que mesmo após a revogação da legislação contrária às seguradoras estrangeiras de Joaquim Murtinho, o Brasil continuou com um setor de seguros nacional bastante dinâmico e mais expressivo que o estrangeiro.

Ao prosseguirmos com a análise a respeito da Manchester Fire Assurance Company, constatamos que seus fundos e bens os quais a diretoria não julgasse necessários para fazer frente às reclamações ou despesas imediatas, eram acumulados e rendiam juros compostos para, nas palavras do estatuto: "constituir competente saldo em poder dos banqueiros, ou para fazer face a quaesquer outros requisitos." ${ }^{543}$ Antes da abertura da filial da Manchester Fire no Brasil, os fundos e bens eram empregados em títulos parlamentares ou títulos públicos da Grã Bretanha, ações bancárias, títulos do Mar Meridional ou das Índias Orientais, letras do Tesouro ou da Marinha, títulos hipotecários da Grã Bretanha e Irlanda, títulos garantidos pela municipalidade de Manchester ou apólices de estradas de ferro, canais, navegação fluvial, empresas de fornecimento de água, barreiras, pontes, taxas paroquiais ou municipais "ou em quaesquer outros títulos que não sejam simplesmente obrigações pessoaes, ou na compra de acções de qualquer companhia de estrada de ferro que estiver effectivamente em trafego ou que se estiver construindo, ou em títulos hypothecarios, sobre apólices emitidas por qualquer associação ou companhia de seguros por toda a continuação da vida." ${ }^{544}$

A diretoria teria a possibilidade de, quando julgasse conveniente, dispor dos referidos títulos e convertê-los em dinheiro, "que por sua vez poderá tornar a ser empregado em acções, apólices ou outros títulos, letras do Thesouro e da Marinha,

${ }_{544}^{543}$ BRASIL, Actos do poder executivo, 1896, p. 703

${ }^{544}$ BRASIL, Actos do poder executivo, 1896, p. 735 
apólices da Índia, annuidades e mais títulos, que vão indicados, em qualquer época, como for mais conveniente." 545

Em 1900, sociedade original de Manchester passa a funcionar no Brasil; a famosa e já citada Lancashire Insurance Company, com capital de 3.000.000 libras dividido em 150.000 ações de 20 libras cada. Concedia seguros de vida "ou contra qualquer eventualidade que involva a duração da vida humana", seguros marítimos e contrafogo. Eram também previstas concessões de seguros contra danos causados por "relampago, saraiva, tormenta, tempestade, terremotos, explosões, cheia ou inundação de água ou outro accidente, bem como segurar o conteúdo de edifícios contra roubos, arrombamentos de casa, presas ou violencias." Os seguros concedidos valiam para patrões e empregados, sendo estes últimos indenizados no caso de danos e prejuízos no ambiente de trabalho. ${ }^{546}$

As operações da companhia estendiam-se para atividades financeiras, tais como concessão de seguros para pagamento de empréstimos com prazo fixo e celebração de contratos para estabelecimento e pagamento de fundos de amortização, depreciação ou renovação. Desde o princípio de sua constituição e de acordo com seu primeiro estatuto, a Lancashire já possuía pretensão de se expandir nos "Estados Unidos da America ou qualquer outro paiz estrangeiro, e estabelecer companhias locaes de conformidade com leis locaes com o fim de fazer qualquer negocio que a companhia esteja autorizada a fazer." No caso de expansão do capital para outras localidades, eram abertas agências e conselhos locais; a diretoria da matriz nomeava os membros, agentes e gerentes de tais conselhos e fixava os seus vencimentos. ${ }^{547}$

Sob permissão dos diretores, a Lancashire Insurance Company poderia empregar seus fundos em participações produtivas ou financeiras que, segundo o estatuto da própria companhia, fossem adequadas aos seus negócios. Os recursos eram investidos em valores ou fundos públicos do Reino Unido ou de qualquer outro governo e Estado estrangeiro. São citados ainda:

títulos, anuidades, apólices, obrigações ou valores do Governo ou do Secretário do Estado das Índias, ou do Governo de qualquer colonia ou dependencia britannica, ou de qualquer

\footnotetext{
${ }^{545}$ BRASIL, Actos do poder executivo, 1896, p. 735

${ }^{546}$ BRASIL, Actos do Poder Executivo, 1900, p. 294, 296, 297, 298.

${ }^{547}$ BRASIL, Actos do Poder Executivo, 1900, p. 324
} 
provincia, cidade ou corporação municipal ou autoridade local das Indias, de qualquer colonia ou dependencia britannica ou de qualquer paiz ou Estado estrangeiro. ${ }^{548}$

Os valores imobiliários e as terras eram constitutivos do patrimônio da companhia e concedidos, como vimos acima, como garantia para empréstimos e reembolsos. São mencionados como focos de investimento terra, censos, foros ou outras rendas e imóveis situados no Reino Unido ou em outras regiões. Era permitido à sociedade conceder empréstimo direto de dinheiro sob condições específicas. Aceitava-se como garantia aos valores concedidos títulos, ações ou garantias de qualquer companhia, além de garantia pessoal com dois ou mais fiadores e uma ou mais apólice de seguro sobre vida. ${ }^{549}$

Os mutuantes sócios tinham o direito de solicitar o reembolso de valores levantados, e eram reembolsados via emissão de debêntures ou valores hipotecários garantidos pelos bens da própria empresa. Deduz-se facilmente que se hipotecas eram dadas como garantia a companhia investia em bens móveis e imóveis. Apesar do direito do reembolso, aos mutuantes não cabia indagar a respeito das dívidas e seus limites. 550

No final de 1896, a Companhia contra os riscos de Transportes e Accidentes de toda natureza La Foncière, criada em Paris em 1893, abre uma filial no Rio de Janeiro. A sociedade era obrigada a ter um representante com plenos poderes atuando no Brasil, capaz de tomar decisões, resolver problemas e dialogar com particulares e governo. ${ }^{551}$ Sua sede social da sociedade era em Paris, com reserva para que se abrissem agências filiais nas colônias francesas e em outros países. Os seguros fornecidos eram de risco por transporte por terra, risco por navegação marítima, navegação interior e acidentes de qualquer natureza. Além disso, a companhia concedia empréstimos a riscos marítimos, empréstimos hipotecários sobre navios e, ao contrário de muitas sociedades da época, cobria riscos de guerra. O valor máximo que a La Foncière poderia conservar sobre um só risco era fixado em 1.500.000 francos, podendo esse valor ser ampliado sob a condição do excedente ser coberto por meio de resseguros. ${ }^{552}$

Como em tantos outros exemplos já citados, os fundos da sociedade não empregados nos gastos de serviços correntes eram utilizados na aquisição de prédios e bens imóveis, títulos de renda sobre o Estado, vales do Tesouro ou outros valores criados e garantidos pelo governo. Chamamos atenção para a contínua compra de ações do Banco

\footnotetext{
${ }^{548}$ BRASIL, Actos do Poder Executivo, 1900, p. 323

${ }^{549}$ Ibidem, 327

${ }^{550}$ BRASIL, Actos do Poder Executivo, 1900, p. 307

${ }^{551}$ BRASIL, Actos do poder executivo, 1896, p. 770.

552 BRASIL, Actos do poder executivo, 1896, p. 773.
} 
da França realizada pela Companhia desde o início de suas atividades, em 1893. Formado em 1800 por Napoleão Bonaparte, o banco detinha o monopólio da emissão da moeda francesa e passou pela ampliação de sua rede de sucursais ao longo do século XIX; sociedades bem-sucedidas cujas reservas não tinham aplicação engajaram-se no financiamento da instituição. ${ }^{553}$

Além dos investimentos acima citados, a La Foncière comprou obrigações das Estradas de Ferro que tivessem um mínimo de juros garantido pelo Estado. ${ }^{554}$ A crise pela qual os países da Europa central vinham passando desde a década de 70 do século XIX, quando as escassas possibilidades de aplicação do capital levaram à deflação e à superacumulação, ao certo influenciou as empresas a se engajarem em projetos cujos resultados se mostrassem bem-sucedidos no médio prazo. A garantia de juros pelo Estado tornava pesados investimentos em infraestrutura e serviços públicos atividades seguras; a compra de debêntures ou de quaisquer outros papéis que financiassem esses grandes projetos naturalmente era mais atraente conforme as perspectivas sobre a economia real fossem boas.

Citamos por fim o envolvimento da companhia com as comunas do Crédit Foncier da França. Fundada em 1852 por Luís Bonaparte, esta sociedade de crédito tinha como objetivo fornecer financiamento às atividades agrícolas via empréstimos sob hipotecas; melhores condições para o financiamento no campo eram reclamadas por pequenos e médios proprietários franceses, décadas antes beneficiados pela reforma agrária de Napoleão I mas impedidos de manter seus lotes de terra pela ausência de recursos. O destino da maior parte da poupança da classe média francesa, desde 1840, ia para as ferrovias, nacionais e estrangeiras, bem como para outros empreendimentos de expansão colonial. A formação do Crédit Foncier e a concessão de crédito agrícola garantiu a Napoleão III o apoio do campesinato, como descrito por Marx em O 18 Brumário de Luis Bonaparte. $^{555}$

Apesar de ter como foco o financiamento da terra, o Crédit Foncier, no entanto, não concedia apenas crédito agrícola, e aos poucos passou também a orientar as poupanças internas em direção à construção de ferrovias em países vizinhos. ${ }^{556} \mathrm{O}$ capital da companhia era fixado em 25.000.000 francos divididos em 50.000 ações de 500

\footnotetext{
${ }^{553}$ BRASIL, Actos do poder executivo, 1896, p. 773.

${ }^{554}$ Ibidem, p. 773

${ }_{555}$ MARX, Karl, O dezoito brumário de Luís Bonaparte. São Paulo: Boitempo, 2011, p. 150.

${ }^{556}$ CASTRO, Ana Célia, obra citada, p. 30.
} 
francos cada; a sociedade reservava-se no direito de aumentar ou diminuir seu capital quando julgasse oportuno. ${ }^{557}$ Dos lucros da companhia retiravam-se antecipadamente, todo ano, 20\% para formação do fundo de reserva e uma quantia suficiente para garantir aos acionistas o juro de $5 \%$ sobre o capital por eles realizado. ${ }^{558}$

Citaremos outro exemplo de expansão do capital francês em direção ao Brasil. Em janeiro de 1898, passou a operar no Rio de Janeiro a Companhia de seguros contrafogo L'Union. A companhia francesa formou-se em Paris em 1828, quando recebeu autorização para funcionar por 50 anos. A duração da sociedade foi prorrogada para um novo período de 99 anos, contados a partir de 01 de janeiro de 1877, salvos os casos de liquidação previstos em seu estatuto; a partir de então adquiriu liberdade para expandir suas atividades para além do território francês. ${ }^{559}$

As suas operações tinham por fim o seguro contrafogo de propriedades móveis ou imóveis, podendo estender sua atuação para danos causados por explosão, casos de insurreição política, guerra e terremotos. Os limites eram claros: o máximo concedido sobre um risco não poderia exceder 500.000 francos para seguros de espécies perigosas, e 100.000 francos para aqueles de espécies menos arriscadas. Através da análise dos documentos não foi possível verificar se os valores eram convertidos em réis de acordo com as variações do câmbio ou se permaneceriam fixos.

A companhia também previa cobrir riscos de resseguros, e os acionistas possuíam obrigações rígidas no que diz respeito às primeiras compras realizadas; deveriam comprar 1/4 (equivalente a 1.200 francos) da importância de cada ação logo que fossem lançadas, além de tomarem o compromisso de investirem mais em breve. Seu capital era fixado em 10 milhões de francos e dividido em 2 mil ações de 5 mil francos cada. Nos maus momentos da sociedade, quando os fundos de reserva sofressem perda, o Conselho de Administração poderia exigir dos acionistas uma entrada proporcional às necessidades da companhia. Os acionistas que não realizassem as entradas solicitadas dentro de vinte dias teriam suas ações vendidas por corretores. ${ }^{560}$

Apesar de não termos informações a respeito das atividades financeiras da Companhia L’Union, sabe-se que esta última também previa a formação de amplo fundo de reserva, construído a partir da dedução de um quinto dos seus lucros. ${ }^{561}$

\footnotetext{
${ }^{557}$ BRASIL, Actos do Poder executivo, 1896, p. 773

558 Ibidem, p. 781.

${ }^{559}$ BRASIL, Actos do Poder Executivo, 1898, p. 05.

${ }^{560}$ BRASIL, Actos do Poder Executivo, 1898, p. 06.

561 Ibidem, p. 12
} 
Por mais que tenha sido mais notável na primeira metade do século XIX, a presença do capital português ainda se fazia presente nos primeiros anos republicanos. Em janeiro de 1900, recebeu autorização para funcionar no Brasil a Sociedade Anonyma Mala Real Portugueza. A companhia, formada em Lisboa em junho de 1888, tinha como objetivo realizar o transporte por via marítima e fluvial de passageiros e mercadorias para qualquer destino e por meio de navios, seus próprios ou de outras sociedades. O interesse passava por qualquer gênero de comércio, e a Mala Real Portugueza tomava concessões e se interessava em realizar negócios com outras sociedades. O seu capital social era de impressionantes Rs 1.800:000\$000, representados por 20.000 ações de Rs $90 \$ 000$ réis cada. $^{562}$

Desde o início de seu funcionamento no Brasil, em 1900, a sociedade encarregava seu Conselho de Administração para a compra dos seguros dos navios; quando estes últimos estivessem livres de encargos e parecesse boa ideia à referida Assembleia correr o risco da ausência de seguros, poderia fazê-lo, desde que contasse com a aprovação do Conselho Fiscal. O mesmo Conselho de Administração era também responsável pela criação de agências em outros portos para além de Lisboa. Quando isso ocorresse, eram considerados acionistas preferidos da companhia. ${ }^{563}$

\subsection{Análise empírica: $1901-1914$}

3.2.1 - A promulgação do Regulamento Murtinho e seu impacto sobre as firmas $\underline{\text { nacionais }}$

Como dito anteriormente, temos que o período compreendido entre 1898 e 1902 foi marcado pela atuação de Joaquim Murtinho, Ministro da Fazenda de Campos Sales, responsável por uma série de reformas preocupadas em combater a herança inflacionária dos anos do Encilhamento, cuja repercussão na dinâmica econômica brasileira fez-se sentir durante toda a década de 1890 .

Em dezembro de 1901, já no final de seu mandato, Murtinho promulgou uma nova legislação regulatória para o setor de seguros, até então fiscalizado por um decreto do ano de 1895. O já mencionado Regulamento Murtinho era bastante rígido no que diz respeito à atuação das firmas estrangeiras, consideradas abertamente como inimigas por parte do Ministro; as repercussões contra as novas regras para o setor foram expressivas, e muitas

\footnotetext{
562 BRASIL, Actos do Poder Executivo, 1900, p. 89

563 Ibidem, p. 92
} 
companhias de seguros estrangeiras se reuniram a fim de pressionar o governo contra o novo marco regulatório. Já em dezembro de 1901, imediatamente após a promulgação da nova lei, as firmas estrangeiras estiveram presentes no Tesouro Federal para uma reunião com o Ministro, afirmando ser impossível a aplicação dos dispositivos exigidos pela lei dentro de apenas 60 dias; Murtinho se mostrou implacável e não prorrogou o prazo. ${ }^{564}$

Dentre as proposições da nova legislação, talvez a mais hostil às companhias de seguros estrangeiras era a que exigia a permanência dos rendimentos das firmas no Brasil, evitando as remessas de lucros que, justamente, prejudicavam o projeto de valorização cambial comandado pelo Ministro. Podemos constatar, portanto, uma relação entre a legislação contrária às seguradoras estrangeiras e o projeto de saneamento fiscal de Joaquim Murtinho; sua preocupação em estabelecer uma dura fiscalização sobre as companhias de seguros estrangeiras, evitando que estas mandassem a maior parte de seus recursos para seus países de origem, inseria-se em um plano mais amplo, a saber, buscar a recuperação do valor da moeda brasileira.

Como apresentado no Capítulo 2 deste trabalho, a despeito de ter sido revogado no ano de 1903, o Regulamento Murtinho surtiu algum efeito e teve papel preponderante na consolidação de um setor nacional de companhias de seguros. Entre os anos de 1901 e 1902 verificamos um aumento no valor das emissões de apólices por parte das companhias brasileiras, de Rs 4.600.000\$000 para Rs 17.900.000\$000. ${ }^{565}$ Veremos adiante alguns exemplos de firmas nacionais funcionando nesse contexto favorável.

\subsubsection{A diversificação nas atividades das companhias de seguros nacionais}

Em março de 1900, antes da promulgação do Regulamento Murtinho, foi fundada no Rio de Janeiro a companhia de seguros mútuos contra acidentes Guanabara. ${ }^{566} \mathrm{~A}$ companhia regulava suas atividades pelo "plano mutuo", e para o cálculo de prêmio, reservas legais e fundo de garantias serviam de base planos e tabelas de companhias estrangeiras, sobretudo da Europa. Adquiriam a categoria de associado todos os que fossem segurados pela companhia, independentemente do valor do seguro; as obrigações dos sócios mutuários não incluíam nenhum pagamento para além do prêmio do seu seguro

\footnotetext{
${ }^{564}$ BRASIL, Retrospecto do Jornal do Commercio. Rio de Janeiro: Typographia do Jornal do Commercio de Rodrigues, 1901, p. 26.

${ }^{565}$ ABREU, Marcelo de Paiva e FERNANDES, Felipe T., obra citada, p. 11.

${ }^{566}$ BRASIL, Actos do Poder Executivo, 1900, p. 285
} 
correspondente. Os membros diretores não poderiam compor a diretoria de nenhuma outra companhia de seguros contra acidentes.

O fundo social da Guanabara era formado por meio da acumulação de todas as prestações, prêmios ou capitais, pagos pelos mutuários donos de apólices; segundo a Companhia, esses valores deveriam ser aumentados pelos juros frutos de investimentos adequados. Sobre os referidos investimentos, a Guanabara empregou seus fundos na aquisição de prédios e em primeiras hipotecas, "livres de todo gravame", em bens de raiz e imóveis situados no Rio de Janeiro, capitais de Estado ou então cidades principais. Eram também comprados títulos da dívida pública da União ou dos Estados e realizados empréstimos sobre apólices de seguros de vida de outras companhias nacionais. ${ }^{567}$ No que diz respeito às causas dos acidentes, a Companhia Guanabara em caso algum garantia "as moléstias e suas consequências, nem os suicídios e os ferimentos resultantes de guerra, revoluções, embriaguez, operações cirurgicas, lutas sportivas e ascensões aeroestaticas. ${ }^{1568}$ Dentre os mutuários sócios da Companhia havia quatro negociantes, um médico, um professor e um industrial. ${ }^{569}$

Talvez a seguradora nacional cujas atividades mais se diversificaram ao longo de seu funcionamento tenha sido a carioca Companhia de Seguros Terrestres, Marítimos, sobre Vida e Comercial America. Formada em março de 1901, possuía prazo de duração inicial de 50 anos e permissão para estabelecer agências em outros estados da União ou em outros países. ${ }^{570}$

Além dos seguros contrafogo, eram protegidas mercadorias por mar, terra ou via férrea para qualquer porto brasileiro ou estrangeiro. Os seguros marítimos garantiam os riscos e perdas por tempestade, naufrágio, variações climáticas, abordagem fortuita, mudança forçada de rota de viagem do navio, entre outros riscos do mar. Eram excetuados todos os prejuízos advindos de "rebeldia ou barataria do capitão e equipagem (...), guerras, detenções de qualquer povo ou potência, hostilidades, pilhagem, pirataria e represálias." Eram também excluídos os riscos de conflitos advindos de contrabando ou atividades comerciais ilícitas. ${ }^{571}$

Os seguros contrafogo eram concedidos a domicílios, estábulos, cocheiras, bem como a "officinas que não tenham ou não estejam ligadas a machinismos a vapor"; deduz-

\footnotetext{
${ }^{567}$ BRASIL, Actos do Poder Executivo, 1900, p. 285

${ }^{568}$ Ibidem, p. 290.

569 Ibidem, p. 292.

${ }^{570}$ BRASIL, Actos do poder executivo, 1900, p. 418

${ }^{571}$ BRASIL, Actos do poder executivo, 1901, p. 426
} 
se daí a indisponibilidade técnica e/ou financeira da Companhia America para envolverse com a proteção de estruturas fabris. Como verificado em tantos outros casos, a companhia, a princípio envolvida apenas na concessão de seguros de vida, marítimos e terrestres, também se engajou em atividades financeiras e oferecia seguros de crédito e garantias comerciais. Sua participação no mercado de especulação imobiliária também chamava atenção: edifícios e estabelecimentos comerciais eram comprados e vendidos pela seguradora, ela própria responsável pelas cobranças e liquidações das vendas.

O fundo de reserva da America era composto sobretudo por apólices da dívida pública, geral ou dos Estados, por letras hipotecárias dos bancos de crédito real, bem como por outras letras que oferecessem garantia precisa à Diretoria. Cessaria o processo de formação do fundo de reserva da companhia quando este último atingisse a quantia de Rs 500:000\$000; a partir de então, os saldos ociosos existentes eram utilizados para elevação do valor dos dividendos distribuídos, sempre no mês de julho de cada ano. O fundo de reserva poderia deixar de existir e ser repartido no caso de findo o prazo de duração da companhia ou quando ela entrasse em liquidação por insolvência. ${ }^{572}$ Para além da compra de títulos da dívida pública ou aquisição de bilhetes privados que compusessem seu fundo de reserva, a carteira de seguros da América incluía a concessão do "seguro de crédito comercial", um título vendido ao comércio que prevenia falências e garantia. ${ }^{573}$

No ato de assinar a proposta de seguro de crédito comercial, o segurado era obrigado a declarar sob quais condições funcionava seu negócio, não omitindo informações a respeito de balanços ou sobre o estado de sua dívida. A preocupação em avaliar o estabelecimento segurado era constante pois a America cobriria suas dívidas no caso de inevitáveis calotes. Nas palavras da própria companhia:

Estando o segurado em condições de embaraço com seus negocios commerciaes e que por isso mereça moratoria, a companhia obrigar-se-ha, de accordo com seus credores, ao pagamento do passivo, ficando o associado segurado obrigado a este pagamento. Si o segurado se achar, porém, em estado de insolvencia, a companhia obriga-se ao pagamento da proposta que fizer aos credores e for por estes aceita. ${ }^{574}$

\footnotetext{
${ }^{572}$ BRASIL, Actos do poder executivo, 1901, p. 426

${ }^{573}$ Ibidem, p. 433

${ }^{574}$ Ibidem, p. 433
} 
A decisão final a respeito de cobertura ou não das dívidas do segurado ficava por conta do Conselho Fiscal da companhia, tendo sempre como base as condições de funcionamento do estabelecimento em questão. Se os credores não aceitassem a proposta de pagamento da América, o segurado permitia que esta o defendesse na Justiça, independente dos custos envolvidos. No caso de os credores aceitarem negociar com a companhia, esta última concederia uma pensão mensal ao segurado durante todo o prazo de liquidação da dívida. ${ }^{575}$

A participação da companhia na concessão de seguros garantidores de dívidas aprofundou sua dimensão financeira; com o tempo, além da proteção no caso de falência, a America passou a se dedicar a empréstimos diretos aos segurados "para desenvolvimento de seus negócios." A estrutura para a garantia de dívidas logo passou a funcionar também para o crédito direto, e a elevada quantia mínima necessária para que a Companhia operasse, Rs 500:000\$000, demostra sua propensão ao aprofundamento dos empréstimos. 576

A obtenção desse crédito direto poderia ser realizada sob algumas condições: o beneficiário deveria comprar uma apólice da companhia, com prêmio de valor variável, e pagar mensalmente a quantia de apenas 3 réis; a partir de então teria acesso a um crédito de Rs 10:000\$000 para estabelecer seus negócios. Toda a transação era descrita pela própria America com o fim de "auxiliar os empregados do commercio, de modo que o mais modesto dos seus auxiliares possa habilitar-se no fim de cinco annos e assim crear um futuro pelos seos esforços e pela honestidade de sua conducta social." ${ }^{577}$

Em abril de 1901, passou a funcionar no Rio de Janeiro a Sociedade Mútua de Seguros sobre a Vida A Nacional. A sociedade estabelecia seguros especiais de pequeno capital para grupos industriais ou agrícolas, pagáveis no caso de morte; estas garantias foram estendias a outros grupos e associações, como veremos adiante. A companhia também concedia seguros de vida e contrafogo, e se responsabilizava por constituir pensões e rendas vitalícias sobre a vida de uma ou mais pessoas. ${ }^{578}$

Eram considerados sócios todos os que adquirissem apólices de seguro de vida, não importando o tipo de contrato assinado. A princípio a única obrigação pecuniária dos membros era o pagamento do prêmio correspondente ao seu seguro; desde o início do

\footnotetext{
575 BRASIL, Actos do poder executivo, 1901, p. 434

576 Ibidem, p. 435

577 Ibidem, p. 434

${ }^{578}$ BRASIL, Actos do poder executivo, 1901, p. 568
} 
funcionamento da companhia, porém, os sócios fundadores foram obrigados a emprestar à sociedade, para garantia de suas operações, o valor conjunto de Rs 120:000\$000. A contribuição dos membros segurados e a possibilidade de sustentarem o caixa da empresa tornou-se recorrente e passou a funcionar como uma opção de financiamento.

Os sócios eram chamados a contribuir com o caixa no caso de a diretoria entender que as circunstâncias assim exigiam. Quando a soma dos prêmios e lucros realizados pela sociedade atingissem a soma de Rs 500:000\$000, os prestamistas poderiam embolsar o valor correspondente de seus créditos. Nesse caso, as obrigações financeiras deixariam de ser responsabilidade dos sócios e ficariam sob encargo único da própria companhia. ${ }^{579}$

Como mecanismo de financiamento havia também a possibilidade de que a companhia vendesse ou hipotecasse seus bens de raiz, móveis ou semoventes. A compra de hipotecas sobre bens de raiz para constituição do fundo de reserva também era realizada, desde que não se adiantasse mais de 50\% na compra e esta fosse mediada por um perito da própria companhia. O referido fundo também era alimentado por títulos da dívida pública e outros bilhetes que "oferecessem vantagem e segurança". 580

De maneira geral, temos que a primeira década do século XX viu funcionar companhias de seguros cuja origem no Brasil remetia ao século anterior; até agora citamos exemplos de firmas estrangeiras que instalaram filiais ou apenas permaneceram funcionando no país a despeito da legislação restritiva ao capital estrangeiro de Joaquim Murtinho em 1903, anteriormente citada. Dentre as companhias nacionais fundadas no século XIX e que permaneciam em funcionamento na primeira década do século XX estão a Argos Fluminense, a Confiança, a Indemnizadora, a Varegista e a muito antiga Garantia, cujo origem no Brasil remete à década de 1860 .

Dentre todas as outras seguradoras em funcionamento nessa mesma data, a partir dos dados coletados no Restrospecto do Jornal do Commercio e do Correio Paulistano, citamos: Minerva, Argos Fluminense, Confiança, Indemnizadora, Varegista, Garantia, Brazil, Brazil Federal, Previdente, Paulista, Companhia de Seguros Marítimos Lloyd Americano, Companhia Prussiana Seguros Contra fogo, Equitativa, Mercurio, The Royal Insurance Company, Cruzeiro do Sul, Guardial Insurance Company, Sun, Albingia Versicherungs, Royal, London and Lencashire, L'Union, Northern Assurance Company, Commercial, Aachen Munich, Union Guardian, Nothern, Companhia de Seguros

\footnotetext{
${ }^{579}$ BRASIL, Actos do poder executivo, 1901, p. 569

${ }^{580}$ Ibidem, p. 572 
Lealdade, União dos Proprietários, Lloyd Americano, Companhia Brasileira de Seguros, Companhia de Seguros Marítimos Tranquilidade, Companhia de Seguros Sul Brasil, Companhia Previdência do Sul, Sociedade Mutua de Peculio e Garantia do Capital Tranquilidade, e Guardian Assurance Company. ${ }^{581}$ Entre março e maio de 1909 essas sociedades tinham suas ações sendo negociadas na Bolsa de Valores do Rio de Janeiro. ${ }^{52}$

Em 1903, após forte pressão de representantes das firmas estrangeiras, o Regulamento Murtinho caiu, e novas legislação foi aprovada sob o Ministério da Fazenda de Leopoldo de Bulhões. Nas palavras do Retrospecto do Jornal do Commercio daquele ano:

Por decreto n. 5072, de 12 de dezembro de 1903 foi approvado o novo regulamento das companhias de seguros de vida, marítimos e terrestres, nacionaes e estrangeiras, estabelecendo regimen mais benigno para todas ellas e collocando-as em perfeito pé de igualdade perante a lei fiscal. ${ }^{583}$

A despeito da queda do marco regulatório hostil às companhias de seguros estrangeiras, constatamos que estas continuaram a ser minoritárias na economia brasileira ao longo da primeira década do século XX. Ao analisarmos os dados a respeito da venda de ações na Bolsa do Rio de Janeiro ao longo do ano de 1903, temos que dentre 16 companhias, apenas uma era estrangeira, a saber, a Lloyd Americano. ${ }^{584}$ A mesma situação se passa para os anos seguintes, até 1914.

Não apenas as companhias de seguros nacionais eram mais expressivas em termos numéricos como também se mostravam mais inseridas na economia brasileira. Para o ano de 1910, por exemplo, temos que apenas as seguradoras nacionais distribuíram dividendos, cujos valores totais variavam; a Garantia, por exemplo, distribuiu Rs 50.000\$000, enquanto a Alliança da Bahia e a Argos Fluminense distribuíram, respectivamente, Rs 123:918\$000 e Rs 120.000\$000.585

A Sul América, em funcionamento no Rio de Janeiro desde 1896 e que em 1910 distribuiu cerca de Rs 50:000\$000, manteve forte atuação financeira ao longo da primeira década do século XX. Sua receita em 1909 veio sobretudo da cobrança de prêmios com

\footnotetext{
${ }^{581}$ BRASIL, Correio Paulistano, Arquivo Público do Estado de São Paulo, 21 de março de 1909, p .04

582 Ibidem, p 04; BRASIL, Retrospecto do Jornal do Commercio. Rio de Janeiro: Typographia do Jornal

do Commercio de Rodrigues, 1909, p. 108

${ }^{583}$ Ibidem, p. 41.

${ }^{584}$ Ibidem, p. 111

${ }^{585}$ BRASIL, Retrospecto do Jornal do Commercio. Rio de Janeiro: Typographia do Jornal do Commercio de Rodrigues, 1910, p. 218
} 
seguros de vida, que representavam Rs 7.411:080\$328; os recebimentos vindos de apólices do governo, títulos, hipotecas e rendas líquidas de imóveis, apesar de menores, tinham o expressivo valor de Rs 1.276:061\$439. ${ }^{586}$ Nesse mesmo ano a seguradora alemã Aechener e Munich, em funcionamento no Brasil desde 1908, adquiriu cerca de 20.000 libras esterlinas em títulos públicos nacionais, elevando o total de seu capital empregado no Brasil para Rs 680:000\$000, ao câmbio de 15d/mil-réis. ${ }^{587}$

Uma relação estreita entre as companhias de seguros e os bancos é visível na documentação analisada. Já nos referimos à proporção que os gastos com seguros representavam no balanço total de instituições como fábricas e bancos; acima citamos o caso do Banco União de São Paulo, que em 1906 teve 2,3\% dos seus gastos totais despendidos com seguros, numa proporção quase igual aos gastos com aluguéis. Em 1910, temos que o Banco de Crédito Hipothecario e Agrícola do Estado de São Paulo gastou $11 \%$ de suas despesas gerais com seguros, viagens e telefones. O crédito do banco com o Tesouro Nacional, por meio de garantia de juros, totalizava o alto valor de Rs $745: 675 \$ 418$, cerca de $82 \%$ do total dos lucros da instituição para aquele ano. ${ }^{588}$

Além dos gastos por parte dos bancos com a compra de apólices de seguros, temos exemplos de suspensão de pagamentos bancários que levaram à falência de seguradoras, como no caso, já referido, do crack do Banco União, espécie de caixa econômica formada pelas poupanças de operários e da classe média, e a Companhia de Seguros Mercurio. Após a falência do Banco União, a Mercurio sofreu um contágio imediato e rapidamente passou por uma liquidação forçada. ${ }^{589}$ Ainda em 1908, uma comissão presidida pelo Inspetor Geral de Seguros do Governo Federal, Vergne de Abreu, analisou a situação da Companhia Mercurio, tendo constatado uma série de abusos e irregularidades por parte de sua administração. As contas da seguradora não haviam sido aprovadas pela Assembleia Geral e nem pelo Conselho Fiscal, ambos reunidos no início do ano de 1908; cerca de três antigos diretores da Mercurio seriam processados pela organização de inventários fictícios, desvio fraudulento de valores pertencentes ao caixa da companhia, sinistros aceitos sem estudo, e concessões de dinheiro concedidas a agentes. Segundo o

\footnotetext{
586 BRASIL, Correio Paulistano, Arquivo Público do Estado de São Paulo, 16 de maio de 1909, p 04.

${ }^{587}$ BRASIL, Correio Paulistano, Arquivo Público do Estado de São Paulo, 23 de fevereiro de 1910, p. 01

588 Ibidem, p. 06.

${ }^{589}$ BRASIL, Retrospecto do Jornal do Commercio. Rio de Janeiro: Typographia do Jornal do Commercio de Rodrigues, 1908, p. 69
} 
Retrospecto do Jornal do Commercio, o prejuízo total para a massa de credores deveria girar em torno de Rs 2.2028:359\$966..$^{590}$

A partir de 1909 constatamos com frequência anúncios de emissões de debêntures nos periódicos de São Paulo e Rio de Janeiro; até então os jornais noticiavam compras e vendas de ações e outros títulos, mas muito raramente anunciavam publicamente pedidos de empréstimo das firmas. ${ }^{591}$ Nestes últimos casos, a descrição da situação financeira e produtiva das sociedades que vendiam suas debêntures incluía a exposição de suas apólices de seguro, que na maior parte dos casos compunha a garantia ao empréstimo. ${ }^{592}$

Em julho de 1910 a Companhia Industrial de São Paulo, produtora de tecidos de algodão desde 1890, lançou publicamente um pedido de empréstimo bastante alto, no valor total de Rs 2.000:000\$000, a serem divididos em 20.000 títulos de Rs 100\$000 cada um. Para atender os serviços de juros e amortizações dos empréstimos, a sociedade destinava reservas anuais no valor de Rs 170:650\$000, de modo que pudesse resgatar o empréstimo dentro dos prazos estabelecidos com os credores. Como garantia foi dada toda a extensão de sua fábrica, situada num terreno de $10.200 \mathrm{~m}^{2}$ no bairro da Santa Ifigênia, em São Paulo. A fábrica possuía maquinário importado e estava segura no valor de Rs 2.500:000\$000 por diferentes companhias, nacionais e estrangeiras, dentre as quais a Preussich National, Northere Assurance, Commercial, Union, Aachen \& Munich, Companhia Previdente e Companhia Paulista de Seguros. ${ }^{593}$

A percepção das companhias de seguros acerca do mercado brasileiro mudava conforme avançava a primeira década do século XX. A próposito do público local se manifestou a Companhia Brasileira de Seguros em julho de 1910:

Os incorporadores da Companhia Brasileira de Seguros, convencidos de que as actuaes condições de progresso, civilização e hygiene em todo o Brasil não são mais as mesmas que nos tempos primitivos, e de que a expansão de sua vída commercial, agrícola e industrial, o desenvolvimento de sua rêde de viação, etc, tudo isto, melhorando sensivelmente as condições de vida em geral e portanto melhorando a sua taxa de

\footnotetext{
${ }^{590}$ BRASIL, Retrospecto do Jornal do Commercio. Rio de Janeiro: Typographia do Jornal do Commercio de Rodrigues, 1908, p. 69

${ }^{591}$ BRASIL, Diário Oficial da União, 27 de março de 1894, p. 1894; BRASIL, Diário Oficial da União, 19 de junho de 1895, p. 3380; BRASIL, Diário Oficial da União, 22 de dezembro de 1896, p. 3436; BRASIL, Diário Oficial da União, 18 de abril de 1897, p. 1941;

592 BRASIL, Correio Paulistano, Arquivo Público do Estado de São Paulo, 14 de maio de 1909, p. 05; BRASIL, Correio Paulistano, Arquivo Público do Estado de São Paulo, 20 de maio de 1909, 07; BRASIL, Correio Paulistano, Arquivo Público do Estado de São Paulo, 30 de janeiro de 1910, p. 08. ${ }^{593}$ BRASIL, Correio Paulistano, Arquivo Público do Estado de São Paulo, 20 de julho de 1910, p.08.
} 
mortalidade, o tem collocado em pé de equaldade com os maiz adeantados paizes europeus e americanos, indicando assim que não se justifica mais a imposição a seus habitantes das pesadas e quasi vexatórias tarifas de prêmios, até aqui conhecidas do público. 594

A Companhia Brasileira de Seguros afirmava trabalhar a partir dos princípios de "liberdade" e "progresso" de modo a sanar uma das mais "palpitantes necessidades e ardentes aspirações" dos brasileiros: a formação de uma "instituição nacional e puramente liberal." 595

O que nos chama atenção no trecho acima reproduzido é a necessidade de cobrar altos prêmios daqueles interessados em apólices de seguro de vida devido às condições precárias sob a qual grande parte dos brasileiros de então viviam. As altas taxas de mortalidade tornavam alta a probabilidade de que as companhias se vissem obrigadas a pagar sinistros aos seus clientes, situação que buscava ser compensada por meio da cobrança de elevadas taxas de prêmios. De certa forma, podemos comparar a necessidade de altos prêmios capazes de compensar a elevada taxa de mortalidade brasileira com os altos juros que, desde então, compensavam o elevado risco de calote sobre os credores.

Já na primeira década do século XX temos que a concorrência entre as companhias de seguros fazia-se em nível mais intenso do que em anos anteriores. A publicação de depoimentos de pessoas físicas, fábricas ou armazéns que afirmam ter efetivamente recebido o valor de seus sinistros tornava-se cada vez mais comum, e as companhias possuíam grande interesse em expor publicamente o valor dos sinistros pagos, como no caso da baiana Companhia Interesse Público de Seguros Marítimos, Terrestres e Contrafogo. ${ }^{596}$ Em dezembro de 1913 a sociedade afirmava ter pago Rs 8.700:000\$000 em sinistros, a maior rubrica de gastos de seu balanço total, ultrapassando os dividendos distribuídos que compunham, em seu total, Rs 2.390:000\$000. Além dos obrigatórios Rs 200:000\$000 depositados no Tesouro, a companhia possuía 600 apólices federais de sua propriedade, num total de Rs 600:000\$000. ${ }^{597}$

Muitas das companhias de seguros citadas nos capítulos anteriores mantiveram uma trajetória ascendente e de ampla inserção no mercado conforme avançavam os

\footnotetext{
${ }^{594}$ BRASIL, Correio Paulistano, Arquivo Público do Estado de São Paulo, 20 de julho de 1910, p.08 595 Ibidem, p.08.

596 BRASIL, Correio Paulistano, Arquivo Público do Estado de São Paulo, 28 de julho de 1912, p. 09. A esse respeito muitos exemplos poderiam ser apresentados; citaremos o caso do sinistro de 40:000\$000 pago pela Companhia Sul América em julho de 1912 em virtude da apólice de um seguro de vida, cuja repercussão no Estado de São Paulo foi expressiva.

597 BRASIL, Correio Paulistano, Arquivo Público do Estado de São Paulo, 03 de dezembro de 1912 , p. 13 
primeiros anos de 1900, quando o país já havia superado a crise do Encilhamento e assistia ao aumento do valor da moeda. Foi esse o caso da Garantia da Amazônia, considerada a maior seguradora do Norte do país. Podemos acompanhar alguns de seus dados desde o primeiro ano de seu funcionamento, em 1898, ano em que Joaquim Murtinho inicia as primeiras políticas de saneamento fiscal, até 1910, quando o total do capital estrangeiro no Brasil havia crescido em comparação ao século XIX. As sobras e outros fundos de reserva da Garantia da Amazônia em 1898 eram de Rs 245:511\$969; em 1899, passam a Rs 491:282\$804; em 1900, a Rs 837:479\$899, e continuam num crescimento contínuo até atingirem Rs 2.992:884\$545 em 1906 e Rs 3.713:853\$854 em 1910, demonstrando boa solvência por parte da empresa e ampla capacidade de formar uma poupança de emergência. ${ }^{598} \mathrm{O}$ total das garantias passaram de Rs 4.957:479\$591 em 1898 para Rs 16.107:406\$259 em 1910, e os sinistros pagos saíram de Rs 319:359\$870 para altíssimos Rs 8.529:041\$855. Essa boa situação da companhia paraense coincide com a expansão da exportação da borracha brasileira, cujos melhores momentos se dão na primeira década do século XX.

O sucesso e a boa situação financeira da Garantia da Amazônia nos seus primeiros anos de funcionamento eram bastante destacados pela companhia, cuja descrição no Almanaque Impressões do Brasil no século $X X$ fazia referência a um suposto "progresso nem mesmo atingido, no mesmo espaço de tempo, pelas suas congêneres norteamericanas". 599 Destacamos que no ano de 1911, ainda sob os estertores do ciclo ascendente do preço da borracha, a companhia paraense detinha Rs 1.144:087\$680 em títulos da dívida estadual, Rs 872:876\$136 da dívida municipal, e Rs 833:747\$110 da dívida do governo federal, além de Rs 652:626\$200 em ações e obrigações de bancos e companhias e Rs 2.673:277\$406 de títulos em depósitos em diversos bancos. Seu ativo financeiro contava ainda com um total de Rs 854:122\$780 a serem recebidos de empréstimos a particulares e Rs 1.203:716\$723 em hipotecas. ${ }^{600}$

Em 1912, a companhia continuava próspera e procurava expandir sua influência no Sudeste, onde encontrava maiores possibilidades de inserção financeira. Em setembro daquele ano, segundo publicação do Correio Paulistano, a Garantia da Amazônia "dava exemplo de sua pujança" ao comprar dois grandes edifícios na Avenida Rio Branco, no

\footnotetext{
${ }^{599}$ BRASIL, Impressões do Brazil no século XX. Lloyd's Greater Britain Publishing Company, Arquivo Municipal de Cubatão, 1913, p. 475.

${ }^{600}$ BRASIL, Correio Paulistano, Arquivo Público do Estado de São Paulo, 26 de junho de 1912, p. 24,
} 
Rio de Janeiro. O jornal louvava o desaparecimento de todos os edifícios de "arquitetura primitiva" e sua posterior substituição por "verdadeiros palácios". ${ }^{601} \mathrm{O}$ otimismo com o "progresso" vivido pelo país, a crença na superação do "arcaico" em nome do "moderno" e um certo espirito ufanista são notáveis no seguinte trecho:

Tão desagradável era a visão recebida ha des annos pelo forasteiro que aportava no Rio, quão agradável é agora a impressão que o mesmo recebe desde a entrada da bahia até nossos pittorescos arrabaldes. Seguindo o progresso crescente que se nota por toda a parte e o renascimento da nossa arte architetonica, nas grandes empresas rejuvenescidas pela nova força que impulsiona os homens e as cousas, tiveram necessidade, já pela marcha ascendente dos negócios, já pela conveniência de terem uma representação condigna de sua importancia, de estabelecerem seus escriptórios com prédios modernos. ${ }^{602}$

\subsubsection{As companhias de seguros e as reformas urbanas do início do século $\mathrm{XX}$}

A referida preocupação com a disposição arquitetônica da cidade também se faz presente na capital paulista, cujas mudanças sofridas na primeira década do século XX foram bastante expressivas. Podemos interpretar essas mudanças, sob o risco de simplificarmos demasiadamente o processo, como a expressão material e urbana do enriquecimento cafeeiro vivido pelo Sudeste desde a década de 1880. Conforme as cidades conheciam o loteamento dos seus terrenos por parte do capital privado e passavam pelo adensamento de sua população, as companhias de seguros invariavelmente encontravam maior capacidade de inserção urbana.

Entre 1899 e 1911, sob a administração municipal do expoente do Partido Republicano Paulista Antonio da Silva Prado, a cidade rompeu com vários de seus elementos coloniais e se transformou profundamente, contando com edifícios modernos, obras de melhoramentos público e influência estética da Belle Époque.

O próprio Antonio da Silva Prado, além de homem público, era fazendeiro e proprietário de diversos negócios cuja expansão deu-se justamente nos momentos de crescimento de São Paulo; citaremos sua Fazenda São Martinho, grande propriedade que empregava cerca de 4.000 trabalhadores; a Companhia Paulista de Vias Férreas e Fluviais, a qual presidiu em 1892; o Banco do Comércio e Indústria de São Paulo, que

\footnotetext{
${ }^{601}$ BRASIL, Correio Paulistano, Arquivo Público do Estado de São Paulo, 05 de setembro de 1912, p. 09. ${ }^{602}$ BRASIL, Correio Paulistano, Arquivo Público do Estado de São Paulo, 05 de setembro de 1912, p .09 
dirigiu entre 1890 e 1920, além do Curtume Água Branca e a Vidraria Santa Marina, ambos de $1895 .{ }^{603}$ No ano de 1913, Antonio Prado passou a ser o presidente da Companhia Agrícola de Seguros, fundada naquele mesmo ano na cidade de São Paulo afim de conceder seguros para máquinas de beneficiamento do café, engenhos de açúcar, arroz, depósitos de café e casas de moradia de colonos e proprietários de fazendas. ${ }^{604}$

Algumas das obras mais importantes construídas na cidade de São Paulo no final do século XIX e início do século XX foram realizadas pelo arquiteto George Krug, filho de norte-americanos instalados em Campinas e formado em arquitetura na Universidade da Pensilvânia, nos Estados Unidos. Krug foi o arquiteto do Colégio Mackenzie, instituição na qual era professor, do British Bank of South America, do London and Brazilian Bank e do Brasilianische Bank fur Deutschland, além dos armazéns gerais Nathan \& Co., do Hospital Samaritano e de mais de cem casas paticulares em São Paulo. 605

Foi também o arquiteto do Brasilianische Bank fur Deutschland da cidade de Santos, além do Estabelecimento de Águas Públicas e dos escritórios da Companhia City Improvements daquela cidade. $\mathrm{O}$ que nos chama particularmente a atenção a respeito da figura deste arquiteto é seu papel desempenhado como árbitro oficial em discussões, levantadas pelo governo e por companhias de seguros, a respeito da ocorrência de acidentes e incêndios nos prédios paulistas. ${ }^{606}$ Seu conhecimento técnico acerca da disposição arquitetônica dos edifícios lhe permitia emitir opiniões sobre incêndios supostamente forjados e sobre os pedidos de pagamento de sinistros considerados "suspeitos" pelas grandes seguradoras.

Muitos desses incêndios eram apontados pelas companhias de seguros como decorrentes da má situação da estrutura urbana brasileira. Desde o início da década de 1890, ainda sob o contexto do Encilhamento, a imprensa noticiava a insatisfação e suspeita das companhias de seguros no Rio de Janeiro com relação a uma série de incêndios considerados demasiadamente sistemáticos. Junto à suspeita de fraude, estava a preocupação das companhias com a ausência de infraestrutura urbana, que potencializava as probabilidades de descontrole do fogo. Na edição de 12 de março de 1891 do Correio Paulistano, após o relato de uma morte causada por incêndio no Rio de

\footnotetext{
${ }^{603}$ LEVI, Darell E., A família Prado. São Paulo: Editora Cultura, 1977, p. 250.

${ }^{604}$ BRASIL. Correio Paulistano, Arquivo Público do Estado de São Paulo, 11 de janeiro de 1913, p. 07.

${ }^{605}$ BRASIL, Impressões do Brazil no século XX. Lloyd's Greater Britain Publishing Company, Arquivo

Municipal de Cubatão, 1913, p. 699.

${ }^{606}$ Ibidem, p. 699
} 
Janeiro, há a seguinte afirmação: "si os incendios continuam dessa sorte, as companhias de seguro fazem greve". ${ }^{607}$

3.3. Mapeamento e cruzamento do capital: os proprietários das companhias de seguros e sua inserção na economia

A diversificação e ampliação do leque de interesses do capital nacional e estrangeiro entre o final do século XIX e início do XX já foi devidamente debatida neste trabalho. No período em questão, temos que a economia brasileira conheceu uma expansão de suas exportações, a entrada de investimentos estrangeiros e o incremento de sua dimensão financeiras. Trataremos agora de apresentar empiricamente exemplos que comprovem o quanto os proprietários de companhias de seguros no período em questão estiveram inseridos em outras frentes de investimento, e o quanto a rede dos negócios brasileiros formava-se e expandia-se em uma conjuntura bastante veloz e prenhe de mudanças. Cabe chamarmos atenção ao fato de que as redes de investimentos e negócios nas quais os proprietários das seguradoras estavam inseridos se tornavam mais complexas conforme avançava o final do século XIX e a primeira década do século XX; a participação financeira das companhias de seguro, que desde a metade do século XIX deixam de ser instituições apenas mercantis, muito tem a ver com a diversificação das atividades de seus proprietários e sócios.

Grande parte dos dados obtidos afim de traçarmos o referido mapeamento veem do Almanaque Impressões do Brazil no século XX, publicação editada na Inglaterra em 1913 e presente no Arquivo Municipal de Cubatão, cujo conteúdo refere-se sobretudo aos negócios fundados em um contexto bastante diferente daquele do início da República e da época do Encilhamento. Alguns investimentos em funcionamento no século XX, no entanto, remetem a períodos anteriores. São muitos exemplos que ilustram o cruzamento entre o ramo de seguros e outras diferentes frentes de aplicação do capital; optamos, portanto, por escolher alguns casos emblemáticos que possam exemplificar as proposições teóricas desta pesquisa.

A princípio, faz-se mais evidente a relação entre diretores de companhias de seguros com os bancos, como no caso da Phenix Fluminense, seguradora cujo diretor, João Francisco Emery, havia sido presidente do Banco Commercial, também do Rio de Janeiro. Outro exemplo: Joaquim José do Santos, diretor da companhia de seguros Argos

${ }^{607}$ BRASIL, Correio Paulistano, Arquivo Público do Estado de São Paulo, 12 de março de 1891, p. 01. 
Fluminense, era também alto funcionário do mesmo Banco Commercial. O presidente do Banco do Commercio, Henrique Corrêa Moreira, foi presidente da seguradora Integridade. ${ }^{608}$

A partir do ano de 1899, a Companhia de Seguros Equitativa dos Estados Unidos do Brasil teve sua seção de seguros terrestres e marítimos comandada por José Ferreira Sampaio, comendador que ocupou diversos cargos públicos desde o Império e que após a proclamação da República passou a trabalhar para o setor privado. José Ferreira Sampaio compôs a diretoria do Banco Crédito Móvel e já no século XX foi presidente do Banco Construtor do Brasil, do Banco do Estado do Rio de Janeiro e da Companhia Nacional de Armazéns Gerais; foi também liquidador da Companhia Internacional Comércio e Indústria, diretor da Estrada de Ferro de Goiás e da Sociedade Anônima $O$ Paiz. $^{609}$

Exemplo interessante a respeito da relação entre diretores de companhia de seguros e as estradas de ferro em expansão no Brasil da época é o caso de Luiz de Freitas Valle, o barão de Ibirocaí, natural de Alegrete, no Rio Grande do Sul. Luiz de Freitas Valle começou sua carreira como corretor de fundos públicos no Rio de Janeiro da década 1890 e tornou-se empreiteiro e construtor de estradas de ferro a partir de 1909. Foi o responsável pela construção da ferrovia de São Luiz a Caxias, no estado do Maranhão, com 400 km de extensão; foi também presidente da Associação Comercial do Rio de Janeiro em 1910 e diretor da Companhia de Seguros Caixa Geral das Famílias, dentre as mais antigas do Brasil. ${ }^{610}$

Citaremos o caso dos proprietários da Rede Telephonica Bragantina, sociedade anônima paulista fundada em 1896 com o capital de Rs 5:000\$000, empenhada na instalação de uma rede telefônica em São Paulo e no Sul de Minas Gerais. Em 1908 a companhia girava com o capital de Rs 200:000\$000 e em 1911 tornou-se uma sociedade de capital aberto. Alguns de seus proprietários, que trabalhavam como gerentes e tesoureiros na sociedade, eram também fiscais da Companhia Mútua de Seguro e Crédito Popular. ${ }^{611}$

\footnotetext{
${ }^{608}$ SUMMERHILL, Willian, obra citada, p. 201.

${ }^{609}$ BRASIL, Impressões do Brazil no século XX. Lloyd's Greater Britain Publishing Company, Arquivo Municipal de Cubatão, 1913, P. 699.

${ }^{610}$ Ibidem, p. 699

${ }^{611}$ BRASIL, Impressões do Brazil no século XX. Lloyd's Greater Britain Publishing Company, Arquivo Municipal de Cubatão, 1913, P. 729
} 
Não era raro encontrarmos à época proprietários de fazendas de café preocupados em deter o controle de toda a cadeia produtiva do produto, desde o plantio até o comércio, passando pelo transporte, pelo crédito e, no caso a seguir, pelo seguro da produção. $\mathrm{O}$ negociante italiano F. A. Danielli, cuja firma homônima foi fundada em São Paulo no início do século XX, era proprietário da fazenda Boa Vista, propriedade com 253.000 pés de café localizada em São Carlos, no interior paulista. A fazenda produzia em média 25.000 arroubas anuais e contava com trabalhadores colonos, que manuseavam máquinas consideradas bastante modernas e complexas para a época; além disso a propriedade possuía luz elétrica instalada em praticamente todo seu território. ${ }^{612}$

A firma de F.A. Danielli era também responsável pela torrefação dos grãos, constituída por mecanismos considerados modernos à época, sendo capaz de torrar 60 arroubas de café por dia, que após moído e empacotado era vendido sob o nome de Café Paulista. Cabe acrescentarmos que Danielli era também proprietário de uma fábrica de gelo, de um frigorífico e de uma fábrica de salame.

A diversificação de negócios que nos chama atenção, no entanto, está no fato de F.A. Danielli ser também sócio da firma Ernesto Whitaker \& Cia., importante estabelecimento comissário de Santos, e gerente da Companhia Brasileira de Seguros, com sede em Araraquara. ${ }^{613}$ A partir desses dados temos confirmado um caso de ampla inserção de um negociante em todas as frentes possíveis relacionadas ao café, o que incluía a participação como gerente em uma seguradora cujo principal objetivo, supomos, era proteger os grãos exportados.

A Carraresi \& Cia., firma de despachantes em Santos e no Rio de Janeiro, foi fundada em 1901 na cidade de São Paulo. Seus proprietários eram consignatários de navios a velas e vapores, além de representarem a Companhia de Navegação Mercante Argentina e "diversas companhias de seguros". ${ }^{614}$ Representavam também fábricas de material para estradas de ferro e construções e estaleiros navais. ${ }^{615}$

Dentre os exemplos encontrados, talvez o mais interessante seja o caso de Asdrubal Augusto do Nascimento. Nascido no Rio de Janeiro em 1854, mudou-se para São Paulo, onde fundou a Companhia Antactica Paulista, possuindo desde seu início o capital de Rs 8.500:000\$000 distribuído em 42.500 ações integralizadas em Rs 200\$000

\footnotetext{
${ }^{612}$ BRASIL, Impressões do Brazil no século XX. Lloyd's Greater Britain Publishing Company, Arquivo Municipal de Cubatão, 1913, P. 729

${ }^{613}$ BRASIL, Impressões do Brazil no século XX, p. 652

${ }^{614}$ Não pudemos descobrir exatamente quais eram essas companhias em questão

${ }^{615}$ BRASIL, Impressões do Brazil no século XX, p. 707
} 
cada uma. Além de cerveja, a companhia fabricava gelo, garrafas e malte, cultivava cevada e aplicava seus resíduos na criação de gado e possuía sua própria usina de gás carbônico no bairro da Mooca, em São Paulo. ${ }^{616}$

Com o sucesso da Companhia Antárctica, Asdrubal do Nascimento tornou-se proprietário do jornal Correio Paulistano e teve ampla inserção na expansão dos negócios industriais e financeiros em São Paulo. Foi um dos fundadores do Banco União de São Paulo e da Companhia Vidraria Santa Marina, esta última junto do antigo prefeito do PRP, Antonio da Silva Prado. Também ajudou a fundar a Fábrica Votorantim, a Companhia de Tecidos de Malha, a Empresa Colonização Sul Paulista e a Companhia Brasileira de Seguro (cujo gerente na década de 1910 era o negociante italiano acima citado F. A. Danielli). Exerceu o mandato de vereador municipal, vice-prefeito e, no final da vida, comprou para si o título de conde. ${ }^{617}$

Buscaremos apresentar exemplos de diversificação do capital brasileiro e dos donos de companhias de seguros fora do Rio de Janeiro e de São Paulo, locais até agora privilegiados pela pesquisa. Em outras regiões brasileiras também encontramos diferentes frentes de investimento e inserção por parte dos proprietários de companhias de seguros. No Estado do Amazonas, funcionava a firma Pinheiro \& Perdigão, um dos principais estabelecimentos de agentes financeiros do Norte do país. A firma havia sido fundada em 1896 em Portugal por Licinio Perdigão e Antonio Pinheiro, ambos naturais da cidade do Porto. Os sócios vieram para Manaus em 1902, afim de expandirem seus negócios e alargarem o campo de operações da casa. ${ }^{618}$

Basicamente funcionavam como um banco, e na década de 1910 administravam cerca de um milhão de libras esterlinas dos "principais capitalistas de Manaus", que confiavam seus capitais à Pinheiro \& Perdigão afim de que estes os empregasse. A firma também se encarregava de administrar edifícios e propriedades e especulava com venda e aluguéis de edifícios, movimentando de 10 a 15 mil libras esterlinas por mês. ${ }^{619}$ Eram agentes da Companhia de Seguros Marítimos e Contrafogo Brazil Seguradora e Edificadora, da Continental Caoutchouc \& Gutta-Percha Co., de Hanover, dentre muitas outras empresas de automóveis, navegação e trabalhos de engenharia. ${ }^{620}$

\footnotetext{
${ }^{616}$ BRASIL, Impressões do Brazil no século XX (...), p. 679.

${ }^{617}$ BRASIL, Impressões do Brazil no século XX (...), p. 679.

${ }^{618}$ BRASIL, Impressões do Brazil no século XX (...), p. 985.

${ }^{619}$ Ibidem, p. 985

${ }^{620}$ Ibidem, p. 985
} 
Também em Manaus funcionava a casa bancária e comercial Amorim Irmãos, fundada em 1893, considerada "das mais conhecidas e reputadas no Norte do Brasil." "621 A firma representava a casa bancária Pinto da Fonseca Irmãos, de Portugal, e possuía sucursais em Juruá e Cruzeiro do Sul. Os proprietários eram donos de seringais no Rio Juruá, e possuíam um vapor que fazia o serviço de transporte da borracha, outras cargas e também passageiros. Do interior recebiam grande quantidade de borracha e cacau, e para o depósito destes produtos possuíam alguns armazéns ao longo do trajeto dos rios.

Dentre os produtos importados da Europa havia comestíveis, ferragens, utensílios caseiros, vinhos, águas minerais; dos estados do Sul do Brasil, carne, arroz, açúcar e café. Entre os seus artigos de importação ocupavam lugar proeminente os produtos dos manufatores ingleses e norte-americanos. Ambos os irmãos Amorim eram fiscais da Companhia de Seguros Lloyd Amazonense, que segurava a maior parte dos produtos importados quando estes permaneciam armazenados nos depósitos. ${ }^{622}$

Citaremos o caso de uma firma produtora de borracha cujos sócios haviam sido diretores da Companhia da referida Seguros Lloyd Amazonense. A Gomes \& Cia., fundada em 1891, era proprietária de seringais e estava bastante inserida no comércio da borracha, bem como de outros produtos regionais da Amazônia, entre as décadas de 1890 e 1910. Possuíam aproximadamente $40.000 \mathrm{~km}^{2}$ de seringais, localizados no Rio Purus e no seu afluente Ituxi; dessa extensão eram explorados cerca de $25.000 \mathrm{~km}^{2}$ e havia 20.000 pés de seringa plantada. A firma exportava, por ano, aproximadamente 750.000 quilos de borracha, e desse total cerca de 500.000 quilos representavam a parte explorada nos seringais do próprio estabelecimento. ${ }^{623}$

Além da produção e venda da borracha, a Gomes \& Cia. funcionava como importadora e comprava cerca de 50 toneladas de castanhas por ano, dentre outras mercadorias, de países como Inglaterra, França, Alemanha e Portugal, e também de outros estados do Brasil. ${ }^{624}$

O capital estrangeiro também estava inserido na exploração da borracha no norte do país; a Leite \& Cia Inc., firma aviadora com sede em Delaware, EUA, foi fundada em 1909 e possuía uma filial em Nova York e uma sucursal no Pará. Sua atividade consistia na exportação de gêneros e mercadorias para o interior da Amazônia, onde recebia a

\footnotetext{
${ }^{621}$ BRASIL, Impressões do Brazil no século XX (...), p. 997

${ }^{622}$ BRASIL, Impressões do Brazil no século XX (...), p. 997

${ }^{623}$ BRASIL, Impressões do Brazil no século XX (...), p. 1006.

${ }^{624}$ Ibidem, p. 1006
} 
borracha que geralmente vendia na praça de Belém. Para realizar o transporte de suas cargas a firma possuía dois vapores. O diretor da companhia no Brasil era Adelino A. Ferreira, que também era presidente da Companhia de Seguros Comercial, com sede em Belém. ${ }^{625}$

Outro exemplo de firma estrangeira no norte do Brasil era a Semper \& Cia., formada por sócios alemães instalados em Manaus. Importavam para o Brasil diversos artigos de uso dos seringueiros e os vendiam em larga escala, na cidade ou no interior do Estado. Em Manaus, eram agentes da máquina de escrever Royal e de várias companhias de seguros marítimos e contrafogo. ${ }^{626}$ Seus vapores circulavam nos importantes rios Purus e Juruá, e recebiam do interior não apenas borracha como também castanha e cacau, que exportavam sobretudo para os EUA e para a Europa. ${ }^{627}$

Desde o final do século XIX o Pará contava com companhias de seguros locais, que funcionavam com agências em outros Estados e cidades. A Companhia de Seguros Paraense, fundada em 1878, em 1913 possuía agências em Pernambuco e em Manaus; havia sido fundada com o pequeno capital de Rs 100:000\$000, e em 1913 este valor fora elevado para Rs 600:000\$000. Em 1911, sua responsabilidade por seguros assumidos era de Rs 75.037:256\$850, sendo a sua receita total de prêmios de seguros terrestres e marítimos, nesse mesmo ano, de Rs 537:008\$497, e os sinistros pagos, Rs 303:021\$302, valores bastante expressivos se comparados a outras seguradoras em funcionamento na mesma época.

A Companhia de Seguros Terrestres e Marítimos Lealdade, fundada em Belém no ano de 1893 com o capital de Rs 1.000:000\$000, foi um exemplo de sociedade de capital aberto bem-sucedida no Norte do país. A Lealdade distribuiu, sete anos após sua fundação, dividendos no valor de Rs 730:000\$000 (cerca de 146\% do valor do capital inicial). A companhia possuía um ativo considerável formado por apólices federais, títulos de empréstimos estadual e municipal, além de prédios nos valores totais de Rs 950:000\$000. ${ }^{628}$

Porém a mais notável companhia de seguros da região Norte do país era a Garantia da Amazônia, cuja atuação incluía uma razoável inserção no Sudeste cafeeiro. Foi fundada em 1897 como sociedade mútua em Belém, e em 1907 suas operações no Sul do

\footnotetext{
${ }^{625}$ BRASIL, Impressões do Brazil no século XX (...), p. 914.

${ }^{626}$ Novamente, não encontramos os nomes das referidas companhias para as quais os sócios da Semper \& Cia. trabalhavam como agentes.

${ }^{627}$ BRASIL, Impressões do Brazil no século XX (...), p. 1002.

${ }^{628}$ BRASIL, Impressões do Brazil no século XX (...), p. 475.
} 
Brasil já haviam tomado bastante forma; neste ano foi fundado o Departamento dos Estados do Sul especialmente para dirigir os serviços desde a Bahia até o extremo Sul. Em 1910 foi criado o Departamento dos Estados do Centro, com sede em Pernambuco, para dirigir os trabalhos do estado do mesmo nome e vizinhos. ${ }^{629}$

Encontramos casos semelhantes em alguns centros do Nordeste. Na Bahia, funcionava desde 1905 a casa britânica Nathan \& Cia, original de Londres, que já operava no comércio sul americano antes de abrir sua filial em Salvador. A firma, que funcionava como exportadora e importadora, exportava sobretudo cacau e café. Importavam "toda a sorte de quinquilharias", materiais para a construção de estradas de ferro, encanamentos e seus acessórios para água e esgotos, máquinas para a lavoura, cimento (sendo agentes da marca Pyramid) e farinha de trigo. As máquinas eram importadas dos Estados Unidos e da Europa e a farinha dos Estados Unidos e Argentina.

Gostaríamos de dar destaque, no entanto, ao fato dos sócios da Nathan \& Cia. serem também agentes da companhia de seguros Northern Assurance Co. Ltd, também britânica em atuação no Brasil. ${ }^{630}$

Cabe aqui chamarmos atenção ao fato de que desde 1870 a Bahia contava com uma companhia de seguros local, a Companhia Aliança da Bahia, sociedade de seguros marítimos e terrestres que foi fundada com o capital subscrito de Rs 2.000:000\$000. A companhia possuía agentes em expressivo número de cidades, dentre as quais Manaus, Belém, São Luiz, Teresina, João Pessoa, Fortaleza, Natal, Recife, Maceió, Juazeiro, Vitória, Cuiabá, Rio de Janeiro, Angra dos Reis, Campos, Belo Horizonte, Juiz de Fora, São Paulo, Santos, Iguape, Campinas, Ribeirão Preto, Curitiba, Paranaguá, Antonina, Ponta Grossa, Florianópolis, Joinville, Pelotas, Uruguaiana, Porto Alegre, Bagé, além de agências internacionais no Uruguai, em Montevieu e Paysandú. ${ }^{631}$ Possuía também representantes em outros países, dentre os quais Arthur Duncker em Hamburgo, Aquilino Ordoñez em Cuba, Mullenkoff \& Korber no Porto Rico; Bolivar \& Cia. em Buenos Aires, e Francisco Basilio e Silvio Gentilli em Trieste. ${ }^{632}$

Na década de 1910 foi diretor da Aliança da Bahia o comerciante José Maria Ferreira Fresco, sócio proprietário da casa Ferreira Fresco \& Cia., firma baiana de 1893 envolvida no negócio de importação e exportação. Importavam mantimentos em larga

\footnotetext{
${ }^{629}$ Ibidem, p. 475

${ }^{630}$ BRASIL, Impressões do Brazil no século XX (...), p. 886

631 BRASIL, Impressões do Brazil no século XX (...), p. 882.

632 BRASIL, Impressões do Brazil no século XX (...), p. 882. 
escala de cidades como Hamburgo, Londres, Bordeaux e Lisboa, além de leite da Nestlé; peixes e frutas em conserva da C. \& E. Morton Ld., de Londres; bacalhau da firma britânica A. \& M. Smith Ld., de Aberdeen e da portuguesa São João da Terra Nova, e manteiga da Dinamarca, além de produtos nacionais, tais como manteiga e toucinho de Porto Alegre. Exportavam sobretudo cacau, café, piaçaba e madeiras, para as quais os mercados principais eram Valparaíso, Lisboa, Porto e diversas cidades da Alemanha. Por ser proprietário da casa de importação e exportação e diretor da Companhia de Seguros Aliança da Bahia, José Maria Ferreira Fresco teve importante participação na Associação Comercial da Bahia, da qual foi presidente, secretário e tesoureiro. ${ }^{633}$

Encontramos exemplo do capital estrangeiro inserido como agente e representante de companhias no Maranhão da década de 1910. A Friedheim, Aguiar \& Cia., firma formada pelo vice-cônsul austríaco em São Luiz e por um fazendeiro de açúcar local, representava no Maranhão a Companhia de Seguros Mannheimer, da Alemanha, a North British \& Mercantile Insurance Co. e a Ocean Marine Insurance Co., ambas de Londres. Outras firmas alemãs e britânicas também estavam presentes na capital, como a HamburgAmerika Linie e a Hamburg Süd-amerikanische Dampfschifffahrts Gesellschft, a Nestlé \& Anglo Swiss Cond. Milk, a R. Singlehurst Co., de Liverpool, a Gasmotoren Fabrik Deutz, de Colônia, a Orenstein \& Koppel, de Berlim, e a famosa Theodor Wille \& Cia, já citada nesta pesquisa. ${ }^{634}$

No Ceará temos o exemplo da Bruno Filho \& Cia., considerada "das mais antigas e reputadas casas de Fortaleza", inserida no comércio de tecidos de algodão, nacionais ou estrangeiros. Além da venda de tecidos e artigos de armarinho, ocupavam-se sobretudo com a compra de borracha, algodão e outros produtos do interior do estado, os quais exportavam para outras regiões do país. Eram agentes da referida Companhia de Seguros Aliança da Bahia. ${ }^{635}$

No Sul do país também nos deparamos com companhias de seguro locais cuja atuação fazia-se de forma bastante expressiva. A Companhia de Seguros Previdência do Sul, fundada em Porto Alegre em 1906 com o capital de Rs 1.000:000\$000, estava desde 1910 envolvida na concessão de empréstimos. A maior parte do crédito concedido faziase sobre hipotecas de prédios ou terras, e desse ramo provinha a maioria do seu lucro e movimento. No seu balanço de 1910 figuravam apólices de seguros da importância de

\footnotetext{
${ }^{633}$ BRASIL, Impressões do Brazil no século XX (...), p. 888.

${ }^{634}$ BRASIL, Impressões do Brazil no século XX (...), p. 1029

${ }^{635}$ BRASIL, Impressões do Brazil no século XX (...), p. 1047
} 
Rs. 9.491:000\$000, número bastante alto que nos demonstra a inserção da seguradora em proteção de mercadorias de alto valor. ${ }^{636}$

Ainda em 1880 foi fundada, também em Porto Alegre, a casa comercial Edward, Cooper \& Cia, formada por negociantes ingleses. A firmava comerciava máquinas e ferragens, que mantinha em grandes depósitos de sua propriedade no entorno do Rio Guaíba. Seus proprietários eram sócios da Companhia de Vidros Sul Brasileira e agentes da Mala Real Inglesa, da Companhia de Seguros Guardian, da Fábrica Brasileira de Extrato de Carne e Couro, da Lipton's Tea Co., da Fábrica de Alpargatas e Nona de São Paulo e da English Thread Co. Ltd. ${ }^{637}$

Na cidade de Pelotas encontramos o exemplo de uma firma bastante antiga, em funcionamento desde 1855, que na década de 1910 permanecia como uma das mais atuantes importadoras da cidade, negociando em comissões e consignações e importando sobretudo sal da Espanha. A F. Nunes \& Cia. exportava ainda charque, couro e sebos para Europa, América Norte e vários outros estados do Brasil.

Seu movimento anual era de Rs $6.000 \$ 000 \$ 000$ e seus sócios fundadores eram agentes do London \& Brazilian Bank Ltd., do Banco do Comércio de Porto Alegre, do British Bank of South America, de Lawson, Son. \& Co., e da Sociedade de Seguros PortoAlegrense. Eram também sub-agentes da Northern Assurance Ltd., do London \& River Plate Bank Ltd. e do Bank of New York. ${ }^{638}$

Também em Pelotas funcionava a casa exportadora de charque Pedro, Osório \& Cia., fundada em 1888; eram agentes da Companhia de Seguros Marítimos e Terrestres Aliança da Bahia, anteriormente citada, e da Empresa de Navegação Sul Rio-Grandense. Importavam sal de Cádiz e exportavam, além do charque, outros tipos de carne e gorduras para o Norte do Brasil. ${ }^{639}$

Porém a maior casa de importação e exportação do Rio Grande do Sul na década de 1910 era a Corrêa, Leite \& Cia., em funcionamento desde 1895. Importava produtos da Europa, EUA, Uruguai, Argentina e de vários portos brasileiros, negociando sempre os mesmos artigos, a saber: açúcar, arroz, sal, café, farinhas, querosene, arame farpado, ferragens e tintas. Exportava basicamente carne seca, e por vender a diversos pontos do Brasil mantinha um quadro fixo de empregados em constante viagem. Seu capital

\footnotetext{
${ }^{636}$ BRASIL, Impressões do Brazil no século XX (...), p. 814

${ }^{637}$ BRASIL, Impressões do Brazil no século XX (...), p. 835

${ }^{638}$ BRASIL, Impressões do Brazil no século XX (...), p. 847

${ }^{639}$ BRASIL, Impressões do Brazil no século XX (...), p. 844 
registrado em 1913 era de Rs 600:000\$000 e o movimento anual ia a Rs 2.000:000\$000. Seus sócios, dentre eles Lucrecio de Oliveira Leite, vice-cônsul de Portugal em Porto Alegre, eram também diretores da Empresa de Navegação Sul Rio Grandense e da Companhia de Seguros Equitativa. ${ }^{640}$

Encontramos outros exemplos de figuras ligadas à diplomacia, como cônsules e vice-cônsules, com alguma inserção comercial. O cônsul da Áustria (na época Áustria Hungria) no Rio Grande do Sul em 1913 era Carl Engelhardt, negociante que migrara para o Brasil ainda jovem. Fundou sua própria firma para realizar o comércio de exportação e ser agente da Companhia de Seguros de Hamburgo. ${ }^{641}$

Casos havia em que o agente representante de companhias de seguro estrangeiras era um indivíduo e não uma firma ou casa comercial, como o exemplo de Gustav Livonius, imigrante alemão natural de Hamburgo que desde 1886 trabalhava como agente geral e representante no Rio Grande do Sul da Preussische National Versicherungs Gesellschaft, de seguros contrafogo, de Stettin; Mannheimer Versicherungs Gesellschaft, Mannheim, de seguros marítimos; Northern Insurance Company Limited, com sede em Londres, também de seguros contra o fogo; e a Companhia Cruzeiro do Sul, do Rio de Janeiro, de seguros de vida e contra acidentes. ${ }^{642}$

Em Santa Catarina, encontramos o caso da firma exportadora e importadora Ernesto Beck \& Cia., com casas em Florianópolis e Laguna, bastante inserida no comércio do interior do estado por meio do trabalho de cinco viajantes fixos. Fundada em 1870, importava ferragens, louças, vidros, gêneros de estiva e outras ferramentas e exportava couros e café. Em 1908, com o crescimento das atividades da firma, seus proprietários ganham alguma notoriedade local e passam a ser agentes da Companhia de Seguros Contrafogo Aachner \& Munchener, além de comissários de avarias das companhias de seguros marítimos Mannheimer e Union Marine Insurance Co. Ltd. Citaremos por fim a casa de comissões e consignações de Eduardo Horn, cujo proprietário homônimo desde 1889 conduzia sozinho seus negócios de importação, a maior parte formada por secos e molhados de países europeus, charque do Rio Grande do Sul e farinha de trigo da Argentina. A casa tinha uma movimentação anual de Rs 1.600:000\$000, e eram exportados principalmente couros, café, frutas e farinha de mandioca. Eduardo Horn, vice-cônsul de Portugal em Florianópolis, era representante do British Bank of

\footnotetext{
${ }^{640}$ BRASIL, Impressões do Brazil no século XX (...), p. 852

${ }^{641}$ BRASIL, Impressões do Brazil no século XX (...), p. 858.

${ }^{642}$ BRASIL, Impressões do Brazil no século XX (...), p. 839
} 
South America e agente de diversas companhias de seguros, dentre as quais a Lloyd Americano, a Garantia da Amazônia e a Companhia de Seguros Contrafogo PortoAlegrense. Companhia Comércio e Navegação, além da Companhia Paulista de Navegação e Comércio, Empresa de Navegação L. Carsoglio e dos Moinhos Santa Lucia. $^{643}$

O navio luso-brasileiro Frederico naufragou em condições trágicas na costa do Marrocos em abril de 1904; o carregamento do navio foi ameaçado de ser pilhado por "uma multidão de beduínos armados até os dentes", que aparentemente não se interessou pelas mercadorias da embarcação e foi embora de mãos vazias. ${ }^{644} \mathrm{O}$ navio e seu carregamento possuíam seguro de Rs 4:000\$000 pela companhia Confiança, baixo se compararmos com o valor de embarcações seguradas pela Companhia Comércio e Navegação, cujos principais navios no ano de 1904 valiam entre Rs 310:000\$000 e Rs 425:000\$000. A Companhia Comércio e Navegação operava a Empresa de Sal e Navegação, cujos principais vapores, Tupy, Amazonas, Nitheroy, União e Assu, saíam de Macau e Mossoró e valiam cerca de Rs 300:000\$000 cada. A Empresa de Navegação Salina, cujas operações marítimas também eram realizadas pela Comércio e Navegação, era proprietária dos vapores Canoé, Aracaty e Maroim, no valor de Rs 800:000\$000 cada. A Empresa de Vapores Idalina, dona das embarcações Idalina, Isabel e Isaura, cada qual valendo cerca de Rs 158.000.000; por fim, a Empresa Marítima Brasileira, proprietária do vapor S. Luiz, no valor de Rs 425:000\$000. ${ }^{645}$

Em 1907 a Companhia Comércio e Navegação estava inserida no tráfico de algodão e álcool, com paquetes saindo regularmente do Recife e prontos para cruzarem o Atlântico ou desembarcarem em Santos ou no Rio de Janeiro. Em março daquele ano um dos navios segurados pela Companhia sofreu um incêndio a partir de uma bituca de cigarro, e todo o navio, bem com a mercadoria de 250 fardos de algodão, ficou destruída. ${ }^{646}$

Ao longo deste capítulo procuramos apresentar novos exemplos da diversificação econômica pela qual as companhias de seguros passaram no Brasil entre 1889 e 1914; buscamos também mapear os nomes por trás dessas atividades e apontar quais as províncias brasileiras, para além do eixo Rio de Janeiro - São Paulo, em que essas

\footnotetext{
643 BRASIL, Impressões do Brazil no século XX (...), p. 1018.

${ }^{644}$ BRASIL, Correio Paulistano, Arquivo do Estado de São Paulo, 1904, p. 01.

${ }^{645}$ BRASIL, Impressões do Brazil no século XX. Lloyd's Greater Britain Publishing Company, Arquivo Municipal de Cubatão, 1913, p. 290.

${ }^{646}$ BRASIL, Correio Paulistano, Arquivo do Estado de São Paulo, 18 de março de 1907, p. 03.
} 
empresas estiveram presentes. Sabemos que o desenvolvimento de novas frentes empresariais no Brasil de então levou à formação de novos riscos, capazes de influenciar e mesmo determinar o padrão de acumulação dessas mesmas atividades. Conforme avançava o século XIX o país tornava-se mais exposto ao comércio internacional, e seus fluxos de trocas internos também se tornavam mais vigorosos. Essa situação pressupunha a existência de seguros capazes de resguardar, total ou apenas parcialmente, o capital investido em máquinas, escravos, expedições marítimas e plantações.

O mesmo desenvolvimento mercantil estimulou o estreitamento de laços financeiros e maior concessão de crédito, que era escasso e instável no Brasil de então. A capacidade de formação de poupança por parte das companhias de seguros, que possuíam dentre suas funções a administração da renda de terceiros, transformou-as em importantes financiadoras da dívida pública federal, como apresentado ao longo deste trabalho. Para além da obrigação de depositarem Rs 200:000\$000 no Tesouro Nacional em troca da carta patente de funcionamento, regra instituída pelo Decreto 294 de 5 de setembro de 1895, as companhias de seguros compravam mais títulos da dívida pública por conta própria, como forma de investimento. A poupança dos segurados administrada pelas companhias era também utilizada para a compra de debêntures e apólices privadas de outras firmas; servia para financiar construções de edifícios e projetos imobiliários; para prestação de serviços a sociedades em crise, que necessitavam de ajuda financeira para tornarem-se solventes e melhor administrarem seu patrimônio, como no caso da Imperial Fire Insurance Company ${ }^{647}$; para concessão de crédito a "industriaes para a execução e desenvolvimento de qualquer invento proveitoso", como no caso da da Companhia de Seguro Contrafogo Americana ${ }^{648}$; para empréstimo de dinheiro contra garantias hipotecárias, como a Companhia de Seguros contrafogo Magburgo ${ }^{649}$, entre outras atividades, todas descritas ao longo do capítulo.

Também procuramos apresentar a relação entre as companhias de seguros e as firmas importadoras e exportadoras brasileiras, muitas destas agentes ou representantes das seguradoras, fossem elas nacionais ou estrangeiras. Companhias de navegação interessaram-se pela concessão direta de seguros, ampliando suas atividades e tornando-

\footnotetext{
${ }^{647}$ BRASIL, Actos do poder executivo, 1892, p. 829.

${ }^{648}$ BRASIL, Actos do poder executivo, 1892, p. 721.

${ }^{649}$ BRASIL, Actos do poder executivo, 1895, p. 63.
} 
se, elas próprias, seguradoras, como no caso da britânica Lupton, ou da fluminense Companhia Comércio e Cabotagem, ambas acima citadas. ${ }^{650}$

A partir da década de 1890 verificamos companhias de seguros inserindo-se como instituições previdenciárias, gerenciando pecúlios de diferentes classes sociais e administrando rendas a serem resgatadas no futuro; recebiam as contribuições, semanais, semestrais, anuais ou de uma só vez, e concediam seguros e montepios no caso de falência ou insolvência de indivíduos ou firmas. Foi esse o caso da Companhia de Seguros Mútuos contrafogo e sobre Vida Cruzeiro ${ }^{651}$, entre outros exemplos citados no Capítulo 2 deste trabalho.

De maneira geral e encaminhando-nos à conclusão deste trabalho, temos que as companhias de seguros foram importantes instrumentos para a acumulação de capital mercantil e financeiro no contexto brasileiro do final do século XIX e início do XX.

${ }^{650}$ BRASIL, Actos do poder executivo, 1891, p. 298.

${ }^{651}$ BRASIL, Actos do poder executivo, 1894, p. 127. 


\section{Conclusão}

A partir do trabalho com as fontes primárias realizado ao longo dessa dissertação, chegamos a algumas conclusões no que diz respeito ao funcionamento do setor de seguros na economia brasileira do final do século XIX e início do XX. Cabe agora destacarmos quais as principais características do setor, levantadas e tratadas ao longo dos capítulos: desde a primeira metade do século XIX o Brasil já contava com companhias de seguros funcionando em seu território, sendo a maior parte delas de origem portuguesa; a partir da década de 1860, as primeiras firmas estrangeiras chegaram ao país, animadas pela vaga de exportação de capital estrangeiro do centro do capitalismo rumo a periferia; mesmo com a entrada de sociedades europeias e norte-americanas, o setor de seguros nacional permaneceu mais expressivo e melhor posicionado na economia doméstica em comparação ao estrangeiro; inicialmente inseridas em uma dinâmica mercantil, aos poucos as companhias de seguros, nacionais e estrangeiras, passaram a mobilizar o capital de terceiros com o qual trabalhavam, formaram poupanças, e tornaram-se instituições financeiras.

Concluímos que ao longo da segunda metade do século XIX o setor de seguros nacional foi mais pujante e representativo que o estrangeiro, situação que se intensificou após a entrada em vigor de leis restritivas às seguradoras forâneas; referimo-nos ao Regulamento Murtinho, legislação promulgada em 1901 que exerceu forte influência negativa sobre as companhias de seguros estrangeiras. Um número muito expressivo dessas firmas deixou o Brasil e rapidamente abriu-se espaço no mercado para as seguradoras nacionais, cuja inserção à época já era sólida. Mesmo após a queda dessa Legislação, em 1903, a participação das companhias de seguro estrangeiras nunca mais se recuperou e o setor nacional pôde de fato se consolidar, como mostram as tabelas 4, 5 e 6 do capítulo 2 .

No que diz respeito à dimensão financeira das companhias, cabe chamarmos atenção para o fato de que o desenvolvimento de um setor financeiro no Brasil de então esteve profundamente ligado à aceleração das relações comerciais ao longo do Império, mais robustas após os anos de parca inserção comercial do país nos circuitos comerciais estrangeiros, sobretudo no período logo após independência. Com um melhor posicionamento do país nos referidos circuitos mercantis, a necessidade de mais crédito, seguros e bancos fez-se patente.

Acima de tudo, as companhias de seguros mobilizaram recursos de terceiros e formaram poupanças, situação pouco usual no contexto brasileiro pouco monetizado 
entre 1889 e 1914. Ao serem bem administradas e terem a sorte de conviverem com a pouca ocorrência de sinistros, essas companhias viram os prêmios obtidos com a venda das apólices se multiplicarem; esses prêmios se transformavam em saldos ociosos com amplo potencial de aplicação. Além de financiarem o Estado, serviram como crédito a outros investimentos produtivos. ${ }^{652}$

Foi através das referidas inserções mercantil e financeira que as companhias de seguros puderam constituir-se como instituições fundamentais ao desenvolvimento do capitalismo no Brasil do final do século XIX e início do XX. Buscamos apresentar ao longo deste trabalho como a complexa consolidação das relações capitalistas em um jovem Estado recém-saído da escravidão não prescindiu de instituições, isto é, de uma rede garantidora de segurança jurídica e facilitadora da acumulação de capital. Ao reafirmarem os direitos de propriedade e ao proporcionarem garantias a riscos e acidentes, as seguradoras contribuíram para o estreitamento dos laços capitalistas entre 1889 e 1914 e, à médio prazo, ao processo de formação do capital industrial brasileiro.

Reafirmamos que este último não foi apenas fruto da transferência de capital do setor agrícola para o manufatureiro, como grande parte da historiografia econômica nos explicou. ${ }^{653} \mathrm{O}$ complexo processo de desenvolvimento industrial brasileiro não poderia ser resumido à transferência de receitas do núcleo agrícola ao fabril; por mais que fundamental, esta explicação por vezes revela-se demasiadamente mecânica e incapaz de incorporar em seu corpus o funcionamento das instituições, consideradas por esse trabalho como parte fundamental da explicação.

A despeito dos obstáculos estruturais que caracterizaram o funcionamento do capitalismo nacional no século XIX e início do XX, durante o Império e nos primeiros anos da República a economia brasileira passou por mudanças bastante amplas. Com o fim da escravidão constatamos a tortuosa instauração do trabalho livre e assalariado no Brasil, aos poucos capaz de promover fluxos de renda monetários. A abolição e a lenta formação de um mercado de trabalho nacional podem ser tidas como marcos significativos na alteração do funcionamento do capitalismo nacional, bem como a

\footnotetext{
$652 \mathrm{O}$ fato das companhias de seguros terem comprado títulos do governo republicano denota confiança por parte dessas sociedades na capacidade de pagamento do Estado, aceitando tornarem-se credoras de um governo recém promulgado e politicamente instável.

${ }^{653}$ Como exemplos dessa literatura, citamos: CARDOSO DE MELLO, João Manuel, O Capitalismo Tardio. São Paulo: Editora Brasiliense, 1982; SILVA, Sérgio, Expansão cafeeira e origens da indústria no Brasil. São Paulo: Alfa-ômega, 1976; CANO, Wilson, Raízes da concentração industrial em São Paulo. São Paulo: Hucitec, 1990; SUZIGAN, Wilson, Indústria Brasileira: origem e desenvolvimento. São Paulo: Editora Brasiliense, 1986.
} 
formação de novos circuitos de comércio, crédito e consumo, estes últimos em muito influenciados pela expansão econômica dos países industriais no contexto da chamada primeira globalização.

De fato, a gênese da indústria brasileira esteve bastante centrada no Sudeste e na acumulação de capital fruto da prosperidade cafeeira; as nuances que diferenciam o processo de industrialização paulista do fluminense foram apresentadas neste trabalho, que se preocupou em não tomar o caso de São Paulo como referência ao processo de industrialização nacional.

Dentre as instituições cujo funcionamento estimulou a acumulação de capital e a formação da indústria nacional estão o crédito e a concessão de seguros. A abertura das primeiras companhias portuguesas, ainda no período colonial, e a consolidação de um setor nacional ao longo do Império culminaram com a vinda de firmas estrangeiras, sobretudo a partir da década de 1860. Conforme aproximava-se o final do século, assistimos a um forte incremento na entrada de capital estrangeiro no Brasil nos mais diversos setores, e as firmas seguradoras nacionais passam a competir com companhias vindas de países como Inglaterra, França, Alemanha e EUA.

À medida que o setor de seguros se consolidava no país, formava-se aos poucos um corpo legislativo capaz de regulá-lo. Nos capítulos referentes à legislação, procuramos mostrar o quanto a promulgação de leis reguladoras da iniciativa privada esteve associada à choques macroeconômicos e a mudanças no funcionamento da economia real. A princípio obedecendo a leis portuguesas, o setor de seguros no Brasil foi regulamentado pela primeira vez com o Código Comercial de 1850, cujo escopo era pouco abrangente e deixava margens para que companhias estrangeiras aplicassem no Brasil a legislação de seus países de origem. Como dito anteriormente, apenas em 1895 tivemos a promulgação da primeira lei específica para o setor.

Entre os anos de 1889 e 1914, a repercussão do funcionamento das seguradoras na economia brasileira fez-se de forma expressiva; cada vez mais os setores exportadores conviviam com garantias às suas transações marítimas; as plantações das fazendas eram protegidas de pragas e incêndios; o incipiente setor manufatureiro contava com cobertura do seu maquinário, e os estabelecimentos urbanos se protegiam dos riscos de incêndio e roubo. Aos poucos os investimentos pressupunham a cobertura de seus riscos inerentes, e o ambiente tornava-se mais propício à acumulação capitalista.

Talvez a principal conclusão desse trabalho esteja na constatação de que o padrão de funcionamento das companhias de seguros no Brasil em muito mudou, sobretudo ao 
longo da segunda metade do século XIX, quando as firmas deixaram de atuar apenas no setor mercantil e exportador e inseriram-se cada vez mais como instituições financeiras. Essa mudança na dinâmica de atuação das seguradoras, verificada a partir dos dados das fontes primárias analisadas, acompanha o contexto mais amplo pelo qual a economia brasileira atravessava desde a década de 1860, a saber, a expansão das possibilidades de crédito e intensificação de seus circuitos.

Essa parece ser a condição da economia internacional nesse mesmo período, cujos fluxos comerciais e financeiros tornam-se cada vez mais articulados e velozes. Entre o último decênio do século XIX e o ano de 1914, período apresentado pela literatura como a Era dos Impérios ou Primeira Globalização, assistimos ao surgimento de novas oportunidades de investimento na periferia do capitalismo. Economias subdesenvolvidas como a brasileira reforçaram seus laços com o centro por meio da ampliação do comércio e das transações financeiras, e estas últimas ganhavam cada vez mais expressão. A exportação de capital das economias avançadas em direção às subdesenvolvidas, característica fundamental do imperialismo, alterou a composição do investimento de muitos setores dos países receptores desse capital; no caso das companhias de seguros, as firmas nacionais continuaram a ser mais representativas, mas todo o setor foi diretamente influenciado pela ampliação da dimensão financeira que marcou o período.

A expansão da capacidade produtiva no Brasil do final do século XIX e início do XX não se fez mais via a simples incorporação de novas terras e expansão agrícola; cresceu a importância relativa dos bancos, das indústrias e dos serviços. A poupança necessária para financiar o processo de formação de capital torna-se naturalmente maior do que em estágios anteriores do capitalismo brasileiro, quando a fronteira produtiva estava sobretudo nas plantações de café. Se a fronteira agrícola deixa de representar a vanguarda da economia, faz-se necessário investir no incremento produtivo e tecnológico do país, bem como em um setor financeiro capaz de financiar esse incremento. ${ }^{654}$

Durante grande parte do século XIX, este último era disfuncional para o crescimento brasileiro, não permitindo o financiamento produtivo; tampouco a poupança nacional suportava a importação de bens de capital que impulsionassem a produtividade da indústria, incipiente e em formação. Os recorrentes déficits na balança de pagamentos e as consequentes crises fiscais atravancavam as necessárias importações e criavam círculos viciosos.

${ }^{654}$ FURTADO, Celso, Desenvolvimento e Subdesenvolvimento. Rio de Janeiro: Fundo de cultura, 1963, p. 206. 
A origem destes círculos viciosos era bastante profunda e as heranças que legaram para o futuro brasileiro também fincaram forte raízes. Talvez pudéssemos identificar o final do século XIX e o início do XX como um período especialmente emblemático para compreendermos os obstáculos ao desenvolvimento brasileiro. Foi nesse período que muitas velhas estruturas foram deixadas para trás e novas aos poucos surgiam e se consolidavam.

Dentre as heranças de longa duração, talvez a mais notável tenha sido a dependência agrícola e os círculos viciosos frutos dessa dependência. Muito se discutiu a respeito das consequências negativas que contínuos programas de valorização do preço do café legaram ao Brasil. A partir de 1906, a queima dos estoques em excesso e a garantia de um bom posicionamento do produto no mercado externo permitiram ao país consolidar sua inserção agrícola na economia mundial.

Sabemos que, antes do início dos programas de valorização dos grãos, buscou-se preservar a renda dos cafeicultores via desvalorização cambial; a ampla rentabilidade do plantio cafeeiro fez dos desestímulos à sua expansão, sucessivamente propostos pelos governos, uma medida de pouco efeito prático. Após 1906, a produção e exportação dos grãos fazia-se em meio à segurança de preços elevados, garantidos pelo Estado.

Se tamanha proteção aos proprietários agrícolas permitiu a manutenção de um nível de renda nacional, bem como maiores possibilidades de arrecadação tributária por parte do governo, por outro lado corroeu recursos e poupanças que poderiam ter sido invertidos de maneira mais vigorosa na formação bruta de capital do país, na consolidação de sua infraestrutura, no aprimoramento de seu setor de serviços e na construção de indústrias.

Sabemos que a economia cafeeira não estimulou a formação de poupanças, e com um mercado financeiro bastante incipiente e com elevados níveis de inflação, não fazia sentido à população aplicar seus rendimentos. Tal situação impossibilitava a formação de um sistema financeiro propriamente dito, capaz de financiar o crescimento, a infraestrutura e a indústria. Se as condições do país eram pouco favoráveis aos poupadores, as possibilidades de financiamento produtivo saíam perdendo.

A despeito da contínua inflação que atingia de maneira profunda a economia brasileira, fruto das recorrentes desvalorizações cambiais apontadas por Celso Furtado, as elites econômicas não inverteram suas poupanças de maneira integral em bens imóveis, cujo rendimento as protegeria das depreciações monetárias. Os títulos públicos e privados, desde as apólices do governo até as letras de crédito agrícola, passando por 
debêntures e hipotecas, atraíram os poucos poupadores de então. Esse trabalho procurou mostrar que, apesar de incipiente e em construção, o mercado financeiro brasileiro do final do século XIX e início do XX aos poucos adquiria uma inserção expressiva na estrutura econômica doméstica. ${ }^{655}$

Dentre os obstáculos à sua consolidação, citamos a constante pressão inflacionária. Sabemos que conforme avançava o século XX brasileiro, mudanças de porte aconteciam nas capitais como Rio de Janeiro e São Paulo, que passaram por reformas urbanas. A complexificação da economia promoveu um forte impulso migratório às cidades, e a urbanização incentivou a pressão da demanda sobre os preços. A vida rural e sobretudo a herança escravista não possibilitavam a ampliação do consumo, que se tornava mais vigoroso conforme se estabeleciam os hábitos urbanos e a necessidade de serviços.

Afinal, o processo de formação do capital industrial, por mais que incipiente no período estudado, exerceu alguma pressão sobre a oferta agrícola brasileira, inelástica e pouco produtiva. As maiores necessidades de investimento que acompanham todos os processos de industrialização e as modificações nos hábitos de consumo decorrentes do crescimento urbano também pressionaram a produção.

Os surtos inflacionários decorrentes de uma economia fundamentada na exportação de bens primários poderiam decorrer das desvalorizações cambiais, realizadas com o intuito de tornar o café mais competitivo no mercado externo, mas também eram desencadeados pelas fases de prosperidade e de preços ascendentes, quando a grande quantidade de papel moeda que entrava no país provocava forte elevação dos preços. A necessidade de "esterilizar" as divisas vindas de fora foi uma das soluções apresentada pela literatura econômica, preocupada com os efeitos advindos do excesso dos meios de pagamentos provenientes dos momentos de alta do preço dos bens primários; se necessário fosse, deveriam ser aumentados os impostos ou até mesmo bloqueados os saldos. ${ }^{656}$

\footnotetext{
${ }^{655} \mathrm{O}$ mercado financeiro nacional passaria ainda por um longo período de consolidação ao longo do século XX, e a dificuldade em estimular as aplicações necessárias ao investimento produtivo não era uma condição restrita ao século XIX. A conhecida Lei da Usura, de 1933, limitava a arrecadação das aplicações financeiras a $12 \%$ ao ano em meio a um contexto de alta inflação e ausência de correção monetária, levando à perda do poder de compra dos poupadores e ao desestímulo à formação de um mercado financeiro nacional.

${ }^{656}$ GUDIN, Eugenio, Inflação: importação e exportação, 2a edição. Rio de Janeiro: Agir, 1959
} 
A proposta de absorção das receitas de exportação via aumento de impostos e bloqueio de saldos, apresentada por Eugenio Gudin para o Brasil de algumas décadas posteriores ao recorte temporal desse trabalho, tem bastante relação com as políticas saneadoras levadas adiante pelo Ministro da Fazenda Joaquim Murtinho entre os anos de 1898 e 1902. Este último ocupou-se sobretudo da valorização cambial, seguro de que a inflação e a moeda depreciada estavam dentre as principais culpadas pelos diversos estrangulamentos da economia brasileira à época. Os déficits públicos, a expansão creditícia, as concessões de contínuas garantias estatais ao lucro do setor privado, entre outras, estavam dentre as políticas econômicas equivocadas do início da República, cuja consequência mais palpável foi a elevação desmedida dos preços durante o Encilhamento. A identificação da inflação como uma distorção perniciosa ao desenvolvimento econômico, no geral, foi apontada por figuras como Joaquim Murtinho, Eugenio Gudin e Celso Furtado.

Um incipiente mercado monetário tornava restritas as possibilidades de controle da inflação. Conforme se expandia a estrutura financeira do final do século XIX brasileiro, podemos pressupor que os mecanismos para combate à inflação cresciam, dentre eles a emissão de títulos da dívida pública que, ao serem comprados, restringiam a quantidade de papel moeda em circulação. Às vésperas da proclamação da República, uma carência de numerário devido à contínuas compras de apólices públicas afetou a disponibilidade do Sudeste brasileiro, como apresentamos no Capítulo 1.

Ao exigir que as companhias de seguros depositassem Rs 200:000\$000 em apólices no Tesouro Federal, o Ministro Joaquim Murtinho formulava um mecanismo de formação de poupança capaz de ampliar as possibilidades de atuação macroeconômica do governo. Não apenas estes depósitos contribuíram para a elevação do valor da moeda como também serviriam para financiar a União.

Em meio à precariedade da concessão creditícia da época, as companhias de seguros inseriram-se no mercado financeiro em expansão no Brasil e colaboraram para sua formação. Atuando como instituições financeiras ou apenas concedendo seguros, as firmas nacionais competiram com uma razoável parcela de sociedades estrangeiras e puderam se estabelecer e prosperar. Constatamos, portanto, que no final do século XIX e início do XX a economia brasileira conheceu o florescimento de um setor estratégico propriamente nacional, capaz de competir com concorrentes estrangeiras e superá-las. 


\section{Referências:}

\section{Fontes}

I.A) Fontes oficiais e de arquivo

Almanack Laemmert, Rio de Janeiro: Typ. Universal de Laemmert, 1899.

BRASIL, Actos do poder executivo, 1889

BRASIL, Actos do poder executivo, 1892

BRASIL, Actos do poder executivo, 1893

BRASIL, Actos do poder executivo, 1894

BRASIL, Actos do poder executivo, 1895

BRASIL, Actos do poder executivo, 1896

BRASIL, Actos do poder executivo, 1897

BRASIL, Actos do poder executivo, 1898

BRASIL, Actos do poder executivo, 1899

BRASIL, Actos do poder executivo, 1900

BRASIL, Actos do poder executivo, 1901

BRASIL, Actos do poder executivo, 1902

BRASIL, Actos do poder executivo, 1903

BRASIL, Actos do poder legislativo, 1895

BRASIL, Coleção das leis do Brasil. Rio de Janeiro: Typhographia Nacional, 1850.

BRASIL, Coleção de Leis do Império do Brasil, 1888, Vol. 01

BRASIL, Correio Paulistano, Arquivo Público do Estado de São Paulo, 1891

BRASIL, Correio Paulistano, Arquivo Público do Estado de São Paulo, 1904

BRASIL, Correio Paulistano, Arquivo Público do Estado de São Paulo, 1905

BRASIL, Correio Paulistano, Arquivo Público do Estado de São Paulo, 1906

BRASIL, Correio Paulistano, Arquivo Público do Estado de São Paulo, 1907

BRASIL, Correio Paulistano, Arquivo Público do Estado de São Paulo, 1908

BRASIL, Correio Paulistano, Arquivo Público do Estado de São Paulo, 1909

BRASIL, Correio Paulistano, Arquivo Público do Estado de São Paulo, 1913

BRASIL, Correio Paulistano, Arquivo Público do Estado de São Paulo, 1910

BRASIL, Correio Paulistano, Arquivo Público do Estado de São Paulo, 1912

BRASIL, Correio Paulistano, Arquivo Público do Estado de São Paulo, 1913

BRASIL, Correio Paulistano, Arquivo Público do Estado de São Paulo, 1914 
BRASIL, Coleção de Leis do Brasil. 1890, Vol. I

BRASIL, Diário Oficial da União, 1893

BRASIL, Diário Oficial da União, 1894

BRASIL, Diário Oficial da União, 1896

BRASIL, Diário Oficial da União, 1897

BRASIL, Lei $n^{o} 3.150$ de 4 de novembro de 1882, p. 1.

BRASIL, Relatório Ministério da Fazenda, 1889-1890

BRASIL, Relatório Ministério da Fazenda, 1891

BRASIL, Relatório Ministério da Fazenda, 1892

BRASIL, Relatório Ministério da Fazenda, 1893

BRASIL, Relatório Ministério da Fazenda, 1893

BRASIL, Relatório Ministério da Fazenda, 1901

BRASIL, Relatório Ministério da Fazenda, 1902

BRASIL, Relatório Ministério da Fazenda, 1903

BRASIL, Relatório Ministério da Fazenda, 1904

BRASIL, Relatório Ministério da Fazenda, 1906

BRASIL, Relatório Ministério da Fazenda, 1907

BRASIL, Relatório Ministério da Fazenda, 1909

BRASIL, Relatório Ministério da Fazenda, 1910/1911

BRASIL, Relatório Ministério da Fazenda, 1913 (I)

BRASIL, Relatório Ministério da Fazenda, 1914

BRASIL, Retrospecto do Jornal do Commercio. Rio de Janeiro: Typographia do Jornal do Commercio de Rodrigues, 1889

BRASIL, Retrospecto do Jornal do Commercio. Rio de Janeiro: Typographia do Jornal do Commercio de Rodrigues, 1901

BRASIL, Retrospecto do Jornal do Commercio. Rio de Janeiro: Typographia do Jornal do Commercio de Rodrigues, 1903

BRASIL, Retrospecto do Jornal do Commercio. Rio de Janeiro: Typographia do Jornal do Commercio de Rodrigues, 1906

BRASIL, Retrospecto do Jornal do Commercio. Rio de Janeiro: Typographia do Jornal do Commercio de Rodrigues, 1908

BRASIL, The Rio News. Rio de Janeiro: Andrew Jackson Lamoureux, 1891

BRASIL, Sociedades Mercantis autorizadas a funcionar no Brasil: 1808-1946. Rio de Janeiro: Dep. Nac. de Indústria e Comércio, 1947. 
BRASIL, Impressões do Brazil no século XX. Lloyd's Greater Britain Publishing Company, Arquivo Municipal de Cubatão, 1913

I.B) Fontes publicadas

SCHOMPRÉ, Émile Quoniam. La Bourse de São Paulo. Typographia Casa Garrauz. São Paulo, 191

\section{I.C) Site}

“Aconteceu em um fim de século”. Folha de São Paulo, 1999. Disponível em http://www1.folha.uol.com.br/fsp/mais/fs21029903.htm.

\section{Bibliografia geral}

ABREU, Marcelo de Paiva e FERNANDES, Felipe T. "The insurance industry in Brazil: a long-term view”. Working paper 10-109, Harvard Business School, 2010.

ABREU, Marcelo de Paiva. "A dívida pública externa do Brasil, 1824-1931". Estudos Econômicos, São Paulo, v. 15, n. 2, 1985

ALBERTI, Verena (coord.). Entre a solidariedade e o risco: história do seguro privado no Brasil. Rio de Janeiro: FGV-RJ e Funenseg, 2001.

ALVIM, Pedro. A intervenção do Estado no mercado de seguro privado. São Paulo: Edição de Manuais Técnicos de Seguro, 1980.

ALVIM, Pedro, Política brasileira de seguros. São Paulo: Ed. Manuais Técnicos de Seguros, 1980.

ANGELL, Norman, A Grande Ilusão. São Paulo: Editora Universidade de Brasília, 2002

ARRIGHI, Giovanni, O Longo Século XX. São Paulo: Unesp, 1996

BASTOS, Pedro Paulo Zaluth, A dependência em progresso: fragilidade financeira, vulnerabilidade comercial e crises cambiais no Brasil (1890-1954). Campinas: UNICAMP. IE, 2001.

BÉRTOLA, Luis \& OCAMPO, José Antonio, O desenvolvimento econômico da América Latina desde a Independência. Rio de Janeiro: Elsevier, 2015

BOHRER, Saulo Santiago. Interesses seguros: As Companhias de Seguro e a Provedoria de Seguros do Rio de Janeiro (1810-1831). Niterói: UFF - dissertação, 2008. 
CAIN, P.J e HOPKINS, A.G. British imperialism: innovation and expansion, 1688-1914. Londres: Longman, 1993.

CANO, Wilson, Raízes da concentração industrial em São Paulo. São Paulo: Hucitec, 1990.

CARDOSO, Fernando Henrique. "Dos governos militares a Prudente-Campos Sales", em FAUSTO, Boris. História Geral da Civilização Brasileira. Tomo III, Vol. 2. Rio de Janeiro: Bertrand Brasil, 2006

CARDOSO DE MELLO, João Manuel, O Capitalismo Tardio. São Paulo: Editora Brasiliense, 1982.

CARVALHO, José Murilo de, Teatro das sombras: a política imperial. Rio de Janeiro: Civilização Brasileira, 2007

CASTRO, Ana Célia. As empresas estrangeiras no Brasil, 1860-1913. Rio de Janeiro: Zahar, 1979.

CHESNAIS, François, A mundialização do capital. São Paulo, Xamã, 1996.

COASE, Ronald, The firm, the market and the law. Chicago: The Chicago University Press, 1988.

CORREA, Fábio Rogério Cassimiro, Os Bancos de Custeio Rural e o crédito agrícola em São Paulo (1906-1914). 2014. 199 f. Dissertação (Mestrado em História). Faculdade de Filosofia, Letras e Ciências Humanas, Universidade de São Paulo, São Paulo, 2014.

COSTA, Ricardo Cesar Rocha da. "A atividade de seguros nas primeiras décadas da República”. ALBERTI, Verena (coord.). Entre a solidariedade e o risco: história do seguro privado no Brasil. Rio de Janeiro: FGV-RJ e Funenseg, 2001.

DEAN, Waren, A industrialização de São Paulo (1880-1945). São Paulo: Difusão Europeia do Livro, 1971.

EICHENGREEN, Barry. A globalização do capital: uma história do sistema monetário internacional. São Paulo: Editora 34, 2007.

EVANS, Peter, A tríplice aliança. Rio de Janeiro: Zahar, 1980.

FAORO, Raimundo, Os Donos do Poder. Porto Alegre: O Globo, 1979.

FAUSTO, Boris, "Expansão do café e política cafeeira”, História Geral da civilização brasileira. Tomo III, Vol. I. Rio de Janeiro: Bertrand Brasil, 1997.

FEIS, Herbert, Europe, the world's banker (1870-1814). Clifton: Augustus Kelley, Reprint of Economic Classics, 1964. 
FISHLOW, Albert, "Origens e consequência da substituição de importações no Brasil", em VERSIANI, Flavio Rabelo \& BARROS, José Roberto Mendonça de., Formação Econômica do Brasil: a experiência da industrialização, série ANPEC, Edição Saraiva, 1977

FRAGOSO, João, FLORENTINO, Manolo, Arcaísmo como projeto: mercado atlântico, sociedade agrária e elite mercantil em uma economia colonial tardia. Rio de Janeiro: Civilização Brasileira, 2001.

FRANCO, Gustavo, Reforma monetária e instabilidade durante a transição republicana. Rio de Janeiro: BNDES, 1983. . "A primeira década republicana". Marcelo de Paiva Abreu (org.). A ordem do progresso. Dois séculos de política econômica no Brasil. Rio de Janeiro. Editora Elsevier, 2014.

FRANCO, Maria Sylvia de Carvalho Franco, Homens livres na ordem escravocrata. São Paulo: Kairós, 1983.

FRITSCH, Winston. “Apogeu e crise na Primeira República: 1900-1930”. Marcelo de Paiva Abreu (org.). A ordem do progresso. Dois séculos de política econômica no Brasil. Rio de Janeiro. Editora Campus, 1995.

FURTADO, Celso. Formação Econômica do Brasil. Rio de Janeiro: Fundo de Cultura, 1959. . Desenvolvimento e Subdesenvolvimento. Rio de Janeiro: Fundo de cultura, 1963

GAMBI, Thiago Fontelas Rosado. O Banco da Ordem: política e finanças no Império brasileiro (1853-1866). São Paulo: Alameda, 2015.

GRAHAM, Richard, Grã-Bretanha e o início da modernização no Brasil. São Paulo: Editora Brasiliense, 1973.

GUDIN, Eugenio, Inflação: importação e exportação, $2^{\mathrm{a}}$ edição. Rio de Janeiro: Agir, 1959

GUIMARÃES, Carlos Gabriel. A Presença Inglesa nas Finanças e no Comércio no Brasil Imperial: Os casos da Sociedade Bancária Mauá MacGregor \& Co. (18541866) e da firma inglesa Samuel Phillips \& Co. (1808-1840). São Paulo: Alameda, 2012

HANLEY, Anne, Native Capital: financial institutions and economic development in São Paulo, Brazil, 1850-1920. Stanford: Stanford University Press, 2005 
HARVEY, David, A produção capitalista do espaço. São Paulo: Annablume, 2005, p. 136.

HILFERDING, R. O Capital Financeiro. São Paulo: Nova Cultural, 1985;

HOBSBAWM, Eric. A era dos impérios. São Paulo: Paz e Terra, 1989. . Da revolução industrial inglesa ao Imperialismo. Rio de Janeiro: Editora Forense, 2000.

HOLlOWAY, Thomas, Vida e Morte do Convênio de Taubaté. Rio de Janeiro: Paz e Terra, 1978.

INSTITUTO DE RESSEGUROS DO BRASIL, Noções fundamentais de seguros. Rio de Janeiro: Imprensa Nacional, 1944.

LEVI, Darell E., A família Prado. São Paulo: Editora Cultura, 1977

LEVY, Maria Bárbara, História da Bolsa de Valores do Rio de Janeiro. Rio de Janeiro: IBMEC, 1977

A indústria do Rio de Janeiro através de suas sociedades anônimas. Rio de Janeiro: Editora UFRJ, 1994.

LISBOA, José da Silva. Reflexões sobre o commercio de seguros. Rio de Janeiro: Imprensa Régia, 1810.

MAGALHÃES, Raphael de Almeida. O mercado de seguros no Brasil. Rio de Janeiro: Funenseg, 1997.

MALAN, Pedro, Política Econômica e industrialização no Brasil. IPEA, 1977

MARCONDES, Renato Leite, $A$ arte de acumular na economia cafeeira: Vale do Paraíba no século XIX. Lorena: editora Siciliano, 1998

MATTOS, Ilmar. O tempo saquarema. A formação do Estado Imperial. São Paulo: Hucitec, 2004.

NETTO, Antônio Delfim, O problema do café no Brasil. São Paulo: Editora UNESP, 2009.

NORTH, Douglass \& THOMAS, Robert Paul, "An economic theory of the growth of the Western World”. Economic history review. Volume XXII, n. 1, 1970.

The Rise of the Western World: a new economic history. Cambridge: Cambridge University Press, 1973.

PAYAR, André Javier Ferreira, A escravidão entre os seguros: as seguradoras de escravos na Província do Rio de Janeiro (1831-1888), 2012, 240 f. Dissertação (Mestrado em Direito). Faculdade de Direito, Universidade de São Paulo, São Paulo, 2012. 
PEARSON, Robin, "Towards an historical model of services innovation: the case of the insurance industry, 1700-1914". Economic history review, n. 2, 1997.

PERISSINOTTO, Estado e capital cafeeiro em São Paulo (1889-1930). São Paulo: Annablume/FAPESP, 2000

POLANYI, Karl, A grande transformação. Rio de Janeiro: Campus, 1980.

PRADO JR., CAIO, Evolução Política do Brasil e outros estudos. São Paulo: Brasiliense, 1963.

RIPPY, Fred. British Investments in Latin America, 1822-1949. Arno Press, 1966.

SAES, Alexandre Macchione; GAMBI, Thiago Fontelas Rosado. "A formação das Companhias de Seguros na economia brasileira (1808-1864)". História Econômica \& História de Empresas. Vol. 12, n. 2, jul. 2009.

SAES, Flávio Azevedo, As ferrovias de São Paulo, 1870-1940. São Paulo: Hucitec, 1981. A grande empresa de serviço público na economia cafeeira (18501930). São Paulo: Hucitec, 1986. Crédito e bancos no desenvolvimento da economia paulista (18501950). São Paulo: Instituto de Pesquisas Econômicas, 1986

SAES, Flávio \& SAES, Alexandre. História Econômica Geral. São Paulo: Saraiva, 2013. SCHULZ, John, A crise financeira da abolição. São Paulo: Edusp, 2013.

SILVA, Sérgio, Expansão cafeeira e origens da indústria no Brasil. São Paulo: Alfaômega, 1976.

SUMMERHILL, William, Inglorious Rvolution: Political Institutions, Sovereign Debt, and Financial Underdevelopment in Imperial Brazil. Yale University Press, 2015

STEIN, Stanley, Grandeza e decadência do café no Vale do Paraíba. São Paulo: Editora Brasiliense, 1961

STONE, Irving. British Direct and Portfolio Investment in Latin America before 1914. The Journal of Economic History 37, no.3, Cambridge University Press, 1977.

SUPPLE, Barry, "Insurance in British History". WESTALL, Oliver. The historian and the business of insurance. Manchester: Manchester University Press, 1984.

SUZIGAN, Wilson, Indústria Brasileira: origem e desenvolvimento. São Paulo: Editora Brasiliense, 1986

TANNURI, Luiz Antonio. O Encilhamento. São Paulo: Hucitec-Funcamp, 1981.

TRINER, Gail, Banking and economic development: Brazil, 1889-1930. New York: Palgrave, 2000. 
VERSIANI, Maria Teresa, "Café e câmbio no Brasil (1890-1906)", in Pesquisa e Planejamento Econômico, 15, dez. 1985

VILlELA, Anibal \& SUZIGAN, Wilson. Política do Governo e Crescimento da Economia Brasileira, 1889-1945. Rio de Janeiro, IPEA, 1973

VIOTTI DA COSTA, Emília, Da Monarquia à República: momentos decisivos. São Paulo: UNESP, 1999

WALLERSTEIN, Immanuel, The rise and future demise of the world capitalist system: concepts for comparative analysis, in Comparative Studies in Society and History, Volume 16, Issue 4, (sept. 1974).

WEINSTEIN, Barbara, A Borracha na Amazônia: expansão e decadência (1850-1920). São Paulo: Hucitec/Edusp, 1993.

WELLER, Leonardo, « Rothschilds' 'Delicate and Difficult Task': Reputation, Political Instability, and the Brazilian Rescue Loans of the 1890s ». Entreprise \& Society : Cambridge University Press, maio de 2015.

WILlIAMSON, Oliver, The Transaction Cost Economics Project: the theory and practice of the governance of contractual relations. Northampton: Edward Elgar Publishing, 2013.

WILLIAMSON, Jeffrey, O'ROURKE, Kevin, "When did globalization begin?" in National Bureau of Economic Research, Cambridge, Massachussets, abril 2000. 
